INTERNATIONAL JOURNAL OF REFORMED THEOLOGY AND LIFE

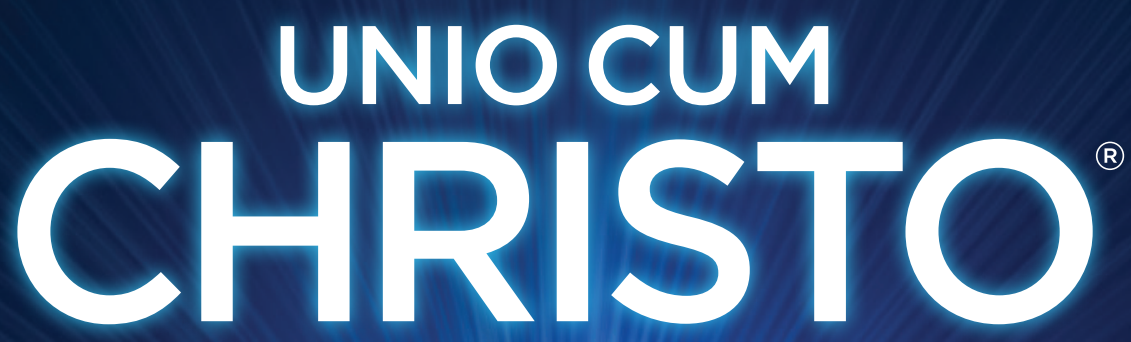

UNION WITH CHRIST

\title{
Luther and the Reformation
}

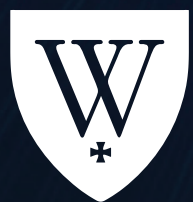

Westminster

Theological

Seminary

Philadelphia

International Reformed

Evangelical

Seminary

uniocc.com

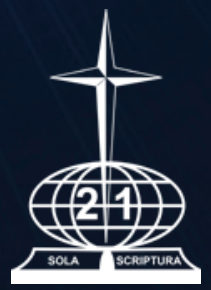




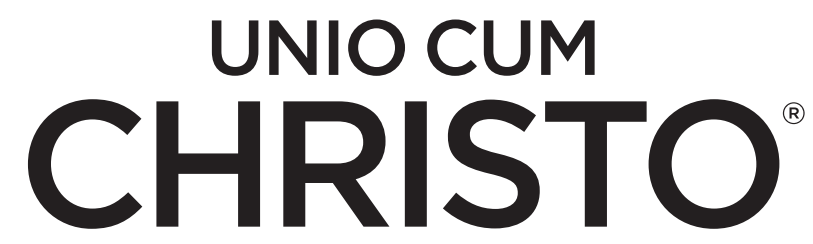

UNION WITH CHRIST

\section{Editorial Committee and Staff}

Editor in Chief: Paul Wells

Senior Editors: Peter A. Lillback and Benyamin F. Intan

Managing Editor: Bernard Aubert

Associate Editor: Jeffrey K. Jue

Book Review Editor: Brandon D. Crowe

Subscription Managers: Audy Santoso and Andrew Colpitts

Assistant: Lauren Beining

Copy Editor: Henry Whitney

Typesetter: Janice Van Eck

\section{Mission Statement}

Unio cum Christo celebrates and encourages the visible union believers possess in Christ when they confess the faith of the one holy catholic and apostolic church, the body of Christ. Thus, its mission is (1) to be an international scholarly and practical journal for the global Reformed community-churches, seminaries, theologians, and pastors; (2) to encourage deeper fellowship, understanding, and growth in faith, hope, and love in the Reformed community at large; and (3) to support small and isolated Reformed witnesses in minority missional situations. It will seek to do so by the publication and dissemination of scholarly contributions of a biblical, theological, and practical nature by Reformed leaders world-wide-including leading theologians, developing scholars, practicing missionaries, pastors, and evangelists.

Articles, interviews, and book reviews will consistently be in line with biblically based Reformed confessional orthodoxy and orthopraxis. Submitted or solicited contributions for its biannual issues will focus on specific themes of importance to the Reformed tradition and present debate.

The opinions expressed in this journal represent the views only of the individual contributors; they do not reflect the views of the editors, of Westminster Theological Seminary, Philadelphia, or the International Reformed Evangelical Seminary, Jakarta.

\section{ISSN 2380-5412 (print) \\ ISSN 2473-8476 (online)}

Copyright (c) 2017 International Reformed Evangelical Seminary and Westminster Theological Seminary. All rights reserved. Unio cum Christo ${ }^{\circledast}$ is a registered trademark of Westminster Theological Seminary, Philadelphia. 
INTERNATIONAL JOURNAL OF REFORMED THEOLOGY AND LIFE

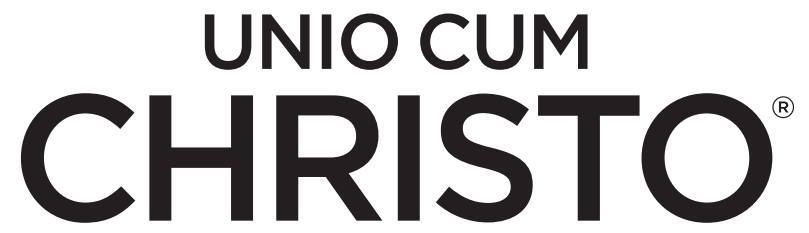

UNION WITH CHRIST

Vol. 3, No. 1 / April 2017

\section{Luther and the Reformation}

Published jointly by

Westminster International

Theological Reformed

Seminary Evangelical

Philadelphia, Seminary

Pennsylvania, Jakarta, uniocc.com

USA Indonesia

info@uniocc.com 


\section{Submissions}

For questions regarding submission of articles, contact Paul Wells at pwuniochristo@gmail.com or Bernard Aubert at baubert@wts.edu. Guidelines of style can be found at our website: uniocc.com.

\section{Subscriptions}

Annual subscription rates are $\$ 35.00$ for institutions, $\$ 25.00$ for individuals, and $\$ 20.00$ for students. Single issues may be purchased at $\$ 14.00$ per copy. Inquiries concerning subscription and orders should be sent to info@uniocc.com.

\section{ISSN 2380-5412 (print)}

\section{ISSN 2473-8476 (online)}

Copyright (c) 2017 International Reformed Evangelical Seminary and Westminster Theological Seminary. All rights reserved. Unio cum Christo ${ }^{\circledR}$ is a registered trademark of Westminster Theological Seminary, Philadelphia.

Printed in the United States of America and Indonesia 


\section{CONTENTS}

\section{Luther and the Reformation}

5 Editorial: Sacred Violence and Justification / PAUL WELLS

\section{REFORMATION THEN AND NOW}

13 The Five Solas of the Reformation: Then and Now / GARRY J. WILLIAMS

35 What Has Mussolini to Do with Hus? / CARL R. TRUEMAN

47 Bound, Freed, Freed to Be Bound: The Wittenberg Understanding of Justification / ROBERT KOLB

\section{LUTHER IN HISTORICAL PERSPECTIVE}

65 Luther and Erasmus: The Central Confrontation of the Reformation / JEAN-MARC BERTHOUD

83 An Introduction to Luther, Calvin, and Their Protestant Reformations / PETER A. LILLBACK

109 Luther and the Spanish Reformers / FRANCES LUTTIKHUIZEN

127 "The Glorious Work of the Reformation": Andrew Fuller and the Imitation of Martin Luther / MICHAEL A. G. HAYKIN

\section{LUTHER, SOCIETY, AND THE CHURCH}

139 Luther and the Turks / HANS SCHWARZ

153 Luther and the Reform of Marriage and Family Life / YOUNGCHUN CHO

171 The Priesthood of All Believers in Africa / CONRAD MBEWE 


\section{CONTEMPORARY ISSUES}

183 Do Judaism, Islam, and Christianity Worship the Same God? A Reformed Theological Perspective / PHILIP TACHIN

201 Transhumanism: Anthropological Challenge of the Twenty-First Century / YANNICK IMBERT

219 The Black Church's Response to the Racialization of Abortion in America / EMMITT CORNELIUS JR.

\section{REVIEW ARTICLE}

235 A Review and Evaluation of J. Richard Middleton, A New Heaven and a New Earth / G. K. BEALE

\section{INTERVIEW}

249 Interview with Dr. William Edgar / PETER A. LILLBACK

\section{BOOK REVIEWS}

265 Thomas R. Schreiner. Faith Alone-The Doctrine of Justification: What the Reformers Taught ... and Why It Still Matters / BRANDON D. CROWE

267 Scott H. Hendrix. Martin Luther: Visionary Reformer / MARTIN LOHRMANN

270 Larry Siedentop. Inventing the Individual: The Origins of Western Liberalism / PAUL WELLS

273 Brad S. Gregory. The Unintended Reformation: How a Religious Revolution Secularized Society / PAUL WELLS

276 Andrew T. B. McGowan. Adam, Christ and Covenant: Exploring Headship Theology / HARRISON PERKINS

279 Sinclair B. Ferguson. The Whole Christ: Legalism, Antinomianism, and Gospel Assurance-Why the Marrow Controversy Still Matters / ANDREW T. B. MCGOWAN

283 Contributors 


\section{EDITORIAL}

\section{Sacred Violence and Justification}

\section{PAUL WELLS}

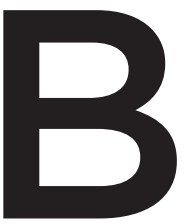

oth the formal and material principles of Luther's Reformation, Scripture alone and faith alone in the justifying effect of Christ's sacrifice, raise criticisms from modern people, as several articles in this issue of Unio cum Christo illustrate. Justification involves Christ dying for us in a substitutionary sacrifice in order to establish the justice of God on our behalf. The glorious transfer implies a certain violence, not one done to us, since by faith we willingly believe, but a violence done to God's own Son, who suffers for our transgressions in order that we go free-unjustly, according to the gainsayers.

One of the major objections to Christian faith on the part of humanists, apart from the claim that all religions are alike and ultimately cancel each other out, is that religions cause insoluble conflict between peoples, nations, confessions, and individuals. Religious violence is an exponential aspect of the problem of evil, the reef on which apologetics often comes to grief. The average punter in the street latches on to this like iron filings to a magnet: look at the religious conflicts in our world today, or look back at the wars of religion and the Inquisition in a hazy past.

Why do religions engender violence? ${ }^{1}$ French anthropologist René Girard developed a much-discussed theory of sacred violence in several of his books and sought to address the fact that violence is deeply rooted in human social experience and particularly in religion. ${ }^{2}$ Why sacred? Because, in the

1 For more on atonement and violence, see Paul Wells, Cross Words: The Biblical Doctrine of the Atonement (Fearn, Ross-shire: Christian Focus, 2006), 81-92.

2 René Girard, Violence and the Sacred (Baltimore: Johns Hopkins University Press, 1977); Things Hidden from Before the Foundation of the World (Stanford: Stanford University Press, 
Girardian perspective, human aggression has a religious character as a pathology in which the neighbor becomes an enemy. Conflict and aggressive rivalry ultimately express a rejection of transcendence. Sacred violence is a reversal of the primordial law to love God and the neighbor as oneself.

Even if the Genesis records represent more for Reformed theology than for Girard, for whom the narratives seem to symbolize the passage from a primitive state of existence to consciousness of evil, his perspectives are illuminating and can be stimulating in the context of covenantal theology. The problem with Girard's thought is that there is no historical passage from original righteousness to sin, and this has profound implications for the meaning of salvation. Genesis, on the other hand, reveals that it is not man who becomes conscious of violence; God himself uncovers the mystery of origins, original goodness and innocence, the first covenant, the appearance of sin and evil in transgression, and the first sacrifice. ${ }^{3}$

However, Girard does seem to think that the Genesis account of origins has universal significance. The primal prohibition of Genesis 2:17 is not restrictive in its intention, but indicates a positive destiny for man, who is neither a double nor an equal of the divinity. Because of this, mimetic rivalry is excluded. Man's life cycle is pointed in the direction of what is good, and the prohibition indicates, a contrario, the completeness of the image of God, male and female. The harmonia mundi includes balanced relationships with the Creator, the neighbor, and the ecosphere. ${ }^{4}$ In this protoeschatological situation, the first and great command, the original law, is to love the Lord, to love the neighbor as oneself, and to care for creation. Obedience in love excludes sacrifice, which is a postlapsarian adjunction resulting from sin. This may be why obedience and sacrifice are often contrasted in Scripture.

How is the primal transgression to be understood? In Genesis 3, "man has now become like one of us, knowing good and evil" (v. 22) is the counterpart of Satan's promise "you will be like God, knowing good and evil" (v. 5). Man's fallen state corresponds to the divine warning "when you eat of the tree of the knowledge of good and evil you will surely die" (Gen 2:17). Prohibition, temptation, desire, transgression, acquisition, opposition, and curse constitute the ethos of human rebellion. Original sin, as transgression of divine law and righteousness, is an act of sacred violence directed

1987); The Scapegoat (Baltimore: Johns Hopkins University Press, 1989). Girard was a member of the Académie française from 2005 until his death in 2015.

3 This is true even if the word sacrifice is not used in Genesis 3:21, as Geerhardus Vos points out. Geerhardus Vos, Biblical Theology (1948; repr., Edinburgh: Banner of Truth Trust, 1975), 156.

4 Colin E. Gunton, Christ and Creation, The Didsbury Lectures, 1990 (Carlisle: Paternoster, 1992), 99-103. 
against God. Presumption is the heart of sin and violence, as man aspires to pseudo-omnipotence.

But who is the victim of violence? God is not the subject or exemplar of violence even though the curse introduces death and sanctions into a good creation. Appearances are misleading because we naturally think that victims suffer because of weakness. However, in this case, God is the object of human violence in Eden, because in mimetic desire man transformed the Creator into a rival and an obstacle to self-promotion. Law breaking dispossesses God of his position and his rights, and as a result, man acts like a god with respect to his neighbor. This is a denial of God's property rights.

God is the primary victim of human violence and as rival and obstacle to human pretensions; God himself ironically becomes the scapegoat of history. Alienation from God is the motivational factor of human guilt transference. False imputation transfers responsibility onto God the enemy. When challenged, guilt is transferred from Adam to Eve to the serpent. By implication it is the Creator's fault. Man looks for scapegoats and is invariably someone else's scapegoat himself.

However, to guile corresponds double guile! God replies to man's guilt transfer with another, which illuminates the sense of the fault. God institutes sacrifice, a blood-victim from his own good creation, in order to signify that another sort of transfer (the blessed one) is necessary to cover man's nakedness (Gen 3:7, 21). The sacrifice instituted by God veils the identity of the true victim. God himself assumes the weight of human guilt and inaugurates the process of reconciliation by expiation.

Reformed theology has, with great clarity, described the nature of biblical reconciliation. ${ }^{5}$ It is not primarily man who is reconciled to God but God, the offended party, who reconciles himself to man. By an unexpected act of grace, God is not the avenger, but the Savior who makes peace. Sin is removed by sacrifice in an act which prefigures the one ultimate sacrifice of the cross. So the sacrificial system of the older testament, instituted by God, hides the identity of the real victim and reveals the divine reply to sin. The response to human violence is not more sacred violence but pardon and grace. The Mosaic covenantal code establishes law and sacrifice as a way of approach to God. Violence is contained and purification of sin through substitution restores right relations with God.

In the Girardian perspective, human aggressiveness has its origin in mimetic behavior, imitation, and rivalry with regard to the neighbor, who

5 Francis Turretin, Institutes of Elenctic Theology (Phillipsburg, NJ: P\&R Publishing, 1994), 2:181-83. 
becomes a threat and an object of envy. Elimination via violence and death is the dénouement of rivalry between opposing parties. The way of defusing antagonism is by focusing it on an excluded third party, or scapegoat, which is sacrificed in a triangular transfer of evil. Thus sacrifice serves to eliminate violent confrontations by crystallizing animosity in a victim; this victim assumes a mediatorial function between opposed parties and, in so doing, becomes a sacred symbol. Sacrifices, which can be repeated, are a way of removing violence and maintaining order. Laws indicate what is prohibited, and repeated sacrifices serve to maintain order and peace in human societies.

Sacred violence is original sin's act of rebellion against God.Violence has been typical of the human condition from that moment on. It implies a reversal of a divine command, which leads to death. So the multiplicity of human religions is not the cause of antagonism but the result of rebellious sacred violence. False sacrifices and victims express man's rejection of God's blessings of life and peace. Here lies the fount of every human aggression and vendetta. Religions are deadly, as Karl Barth claimed, because they are essentially idolatrous: "The human righteousness of religion, of pious man, of phariseeism, the man-made righteousness ... is nothing other than 'irreverence and insubordination."' By contrast, the original divine law of love and justice is summarized in the words of Jesus: "Love the Lord your God with all your heart. ... Love your neighbor as yourself" (Matt 22:37-38). The Creator's intention for life and fellowship in paradise was nothing other than ordered love, according to the laws of divine nature, which was forfeited when man put his own pseudopower in the place of God's. As a creature in the image of a righteous God, what rebellious man requires is not love but justice and justification. God's cure for human violence is not homeopathic, treating violence by counterviolence in a self-perpetuating cycle, but allopathic, healing violence by an act of justice and love. This is why the doctrine of justification is not violence done by God against his beloved Son, but a means of the eradication and healing of violence in reconciliation. It includes propitiation, which is not God's anger against his Son, but against the sin assumed and borne in self-giving sacrifice by the Mediator. Human violence, on the contrary, is Stalinistic and intended primarily to liquidate rivals.

Jesus warned his followers that those who take the sword also perish by it (Matt 26:52). But that is what religions have invariably done-sadly, Christendom as well. Every form of idolatry promotes its sacrifices,

6 Gerrit C. Berkouwer, The Triumph of Grace in the Theology of Karl Barth, trans. Harry R. Boer (Grand Rapids: Eerdmans, 1956), 27. 
worship, legislation, and traditions as being superior to and exclusive of others. Religions, like other expressions of sinful human power, engender rivalry, idolatry of ideology, and ultimately violence, war, and death. In Girard's theory, exclusion is a litmus test which reveals the presence of sacred violence. ${ }^{7}$ Judaism, like other religious faiths, is exclusive, even if in the Abrahamic perspective all the world will be blessed (Gen 12:3) and the Decalogue repeats the creational charge to love God and the neighbor. However, the history of Judaism, culminating in the rejection of the Messiah, is typical of a spirit of self-righteousness and division characteristic of all religions.

Saul of Tarsus, a ritualistic kosher and Sabbath observer, was a prime example of this ethos before Paul the apostle emerged as defender of the reconciliation of Jews and Gentiles in the body of Christ through the sacrifice of the cross. Paul had considered the cross a scandal in light of the law and its ordinances (1 Cor 1:22), but he came to interpret the law in light of the cross, which constituted a $180^{\circ}$ conversion. Galatians 2:20 is capital: "I have been crucified with Christ and I no longer live but Christ lives in me," which interprets the previous verse, "Through the law I died to the law that I might live for God." Christ died because of the law, and Saul with him. Justice comes not from conformity to rituals but through the sacrifice required by the law. Thus Christ is "the end [telos, fulfillment] of the law for righteousness" (Rom 10:4). Reconciliation is through expiatory sacrifice: "The Son of God loved me and gave himself for me." To die and live with Christ is to die to the law and to all laws as ritual systems of exclusion founded on sacrifices and violence, by identification with the one who was the ultimate victim of violence and exclusion.

The apostle proposes a new universal belief founded on reconciliation through the cross. This definitively deconstructs the patterns of mimetic violence, scapegoating, and exclusion found in Judaism and in all natural religion. Paul describes man-centered religion with metonymies such as law, flesh, circumcision, old man, old creation, world, body (of sin), Adam, and death. The sending of Christ in Galatians 4:4 is the opposite of the sending away of the scapegoat on the Day of Atonement. Christ is sent into the sphere of sacred violence and the flesh in order to make an end to man's religion of self-atonement. Henceforth no more sacrifices are required, nor laws to be obeyed, nor ostracisms to be maintained for salvation, as the

7 Exclusion is the opposite of hospitality. Cf. Paul Wells, "Hospitality and Ministry in Trinitarian Perspective," in Triniteit en kerk, Festschrift Arie Baars, ed. G. C. den Hertog, H. R. Keurhorst, H. G. L. Peels (Heerenveen: Groen, 2014), 174-84; Hans Boersma, Violence, Hospitality, and the Cross (Grand Rapids: Baker, 2004). 
work of Christ has changed the way to God once and for all. Union with the victim in death and resurrection tolls the knell of human violence.

A commentator of Girard's thought has said that the first effect of the cross is to unveil sacred violence rather than being a transaction that appeases divine wrath. ${ }^{8}$ But this bipolarization is neither useful nor necessary nor biblical. The cross marks the end and the failure of the practices of self-atonement not only because of the result obtained, but also because it fulfills God's plan to justify sinners. Without the divine intention to accomplish reconciliation in this way, the cross is merely exemplary, which annuls the hapax of the New Testament. Even if the model of divine substitution and obedience has evocative power, its ultimate efficacy is in the removal of condemnation and in justification because "one died for all, and therefore all died" (Rom 8:1; 2 Cor 5:14). Sacred violence is finished in the objective sense because the ultimate sacrifice has been made and God is propitiated. David Chytraeus, a disciple of Luther and Melanchthon, wrote,

The efficient principal cause of Christ's sacrifice is the will of God's Son, who voluntarily turned upon Himself the wrath of God against sin and underwent abuse and dreadful torments of soul and body, so as to make satisfaction for the sins of the human race and, with the placation of God's wrath, restore righteousness and eternal life to men. ${ }^{9}$

Sacred violence is objectively dealt with at Golgotha because human rivalry, guilt, sacrifices, and scapegoating have been exposed as false expressions of man's pseudoreligious attempts to deal with the problem of hatred and aggression. God breaks the karma of human violence, and those who, like Saul of Tarsus, had been caught in the spider's web of exclusion are liberated by union with the only victim required by God. As Rousas Rushdoony affirms, "Man cannot get rid of the burden of sin by himself. Man tries, first, either to pay for his sins himself by masochistic activity, a futile process, or second, to make others pay for them through sadistic activities. Both alternatives lead to sick lives and sick societies." ${ }^{\prime 0}$ In Christ, the destructive rivalries of domination give way to faith, hope, and love stimulated by positive mimesis. New life is liberation through dying and rising

8 Robert G. Hamerton-Kelly, Sacred Violence: Paul's Hermeneutic of the Cross (Minneapolis: Fortress, 1991), 79. Girard's views on sacrifice and expiation seem to change at a later stage in his work: René Girard, I See Satan Fall like Lightning (Maryknoll, NY: Orbis Books, 2001), part III.

9 David Chytraeus, On Sacrifice: A Reformation Treatise in Biblical Theology (De Sacrificiis, 1569), trans. John W. Montgomery (St. Louis: Concordia, 1962), 80-81.

${ }^{10}$ Rousas J. Rushdoony, The Politics of Guilt and Pity (Fairfax, VA:Thoburn, 1978), 17. 
with Christ; all those who belong to the new humanity by identification with the one victim are brothers and fellow servants. The only "sacrifices" left to be made are free and living ones in the liberty of new obedience (Rom 12:1-2).

The power of the cross is not illustrative of a possibility open to man, but results from divine substitution. Romans 3:25 indicates that "God presented Christ as a propitiation (hilasterion) by his blood." This refers not to the scapegoat of the Day of Atonement, but to the Passover sacrifices made for the expiation of sin. Biblical sacrifice does not primarily have a liturgical function or present an exhortatory symbol, but is an act of penal substitution. As "the lamb of God who takes away the sin of the world" (John 1:29, 36), Christ on the cross is judged before the divine tribunal. Assuming our sin in an act of divine imputation, Christ dies in the place of the unjust (1 Pet 3:18) and so undergoes punishment in our place in judgment, merited condemnation, death, hell, and separation from God. The blood of Christ saves us, and blood evokes violent death. The result is justification by faith for those for whom Christ died.

In some recent "evangelical" theology a tendency has arisen to accept the substitutionary character of the cross but to deny its penal and expiatory character. These reinterpretations fall short of the New Testament teaching that is based on the Levitical sacrifices, which symbolize the transfer of sin, and consequent death, as necessary for restoration of communion with God. The effect of the sacrifice of the cross is the removal of sin because divine wrath is propitiated. Leon Morris has indicated that propitiation is a fully personal act on God's part. ${ }^{11}$ Because sin is removed by expiation, the wrath of God no longer concerns those for whom Christ died, and a relationship of reconciliation is established with them.

Propitiation, the turning away of the anger of God against sin, is the summit of divine reconciliation and the presupposition of reconciliation and justification. Covenantal mediatorial sacrifice reveals the fullness of the divine plan of salvation which an exemplary abolition of sacred violence could never attain. Wolfhart Pannenberg sums it up by saying,

The vicarious penal suffering, which is rightly described as the vicarious suffering of the wrath of God at sin, rests on the fellowship that Jesus Christ accepted with us sinners and with our fate as such. This link is the basis on which the death of Jesus can count as expiation for us. ${ }^{12}$

${ }^{11}$ Leon Morris, The Atonement (Leicester: Inter-Varsity Press, 1983), 55.

12 Wolfhart Pannenberg, Systematic Theology (Grand Rapids: Eerdmans, 1994), 2:427. 
Finally, a structural difference exists between human religions and biblical revelation. Biblical history is told from the side of the victim; mythology narrates it from the side of dominant power. Scripture demythologizes the structures of sacred violence, rebellion against God, and human selfsalvation. God and Christ are victims because of human rebellion and destructive $\sin$, and sacrifice is transformed into a manifestation of love, which reconciles to God. Positive imitation of Christ, based on divine forgiveness through blood atonement and the declaration of justification through faith, opens the way to liberation from violence and conflict of all kinds. The believer is freed definitively from the fear of guilt manipulation by others and also from the self-pity of a victim mentality. Conversely, freedom is also being freed from making others victims and being set at liberty to follow the perfect law of love, which casts out fear, as in the parable of the good Samaritan. 


\title{
The Five Solas of the Reformation: Then and Now
}

\section{GARRY J. WILLIAMS}

\begin{abstract}
After a description of the five solas of the Protestant Reformation and their biblical basis, the rejection of the solas by the Roman Catholic Church at Trent and Vatican I is traced, focusing on revelation, justification, and worship. The account of Roman Catholic theology is brought up to date by an examination of changes that occurred at Vatican II. A different stance toward Protestants and the wider world is explained by a shift in the Church's view of the nature-grace relationship. Despite this change, the core commitments of the Catholic Church on revelation, justification, and worship remain unaltered. They are held within a less adversarial but still expansionist Rome-centered theology that Protestants must continue to resist.
\end{abstract}

\section{Introducing the Five Solas}

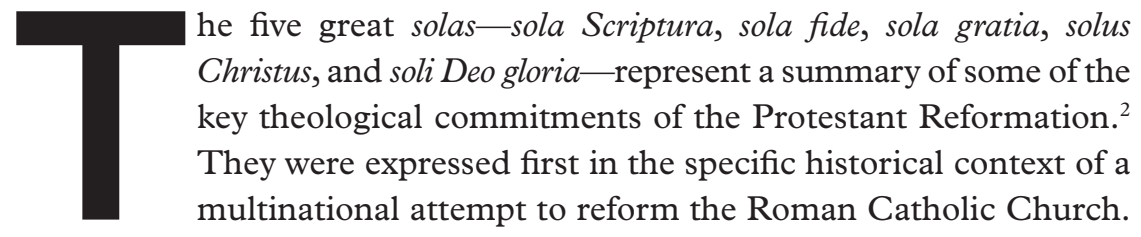

1 This article is a revised and shortened version of Garry J. Williams, Why Protestant Truth Still Matters: A Biblical Perspective (London: Protestant Truth Society, 2014).

2 "Solas" is widely used as an anglicized plural of the feminine of the Latin word solus, meaning "alone." 
That attempt met with immediate resistance and it was apparent quite early - certainly following the failure of the Colloquy of Ratisbon in 1541that Rome would accept no doctrinal reform. When it came, Rome's own "Catholic Reformation" was willing to embrace the need for a moral reform of the Church, but it would not accept Reformation theology. At the Council of Trent (1545-63) Rome's response to doctrinal criticism was one of reactionary entrenchment.

Nonetheless, the substance of the solas was born not from controversy but from Scripture, as sola Scriptura requires. The Reformation is rightly understood as a return ad fontes (back to the sources), to the inspired, binding, and sufficient text of the Christian faith. None of the Reformers believed that they were innovating. As the Elizabethan bishop John Jewel puts it in his apology for the Church of England, "God's holy Gospel, the ancient bishops, and the primitive church do make on our side." ${ }^{\prime 3}$ Understood historically, Protestant theology was always reactive to Rome; understood theologically, it is the fruit of obedient submission to the tutelage of Scripture. I will therefore examine first the biblical foundation for the solas, and then their role in defining Protestantism against Roman Catholicism. As soon as we broach this second aspect, it becomes vital to consider the ways in which Rome has changed since the sixteenth century: is the Rome of Vatican II (1962-65) still the Rome of Trent?

\section{The Solas Stated}

\section{Sola Scriptura}

Measured theologically, two of the five solas stand out: sola Scriptura and solus Christus. In the order of knowing, sola Scriptura comes first because Scripture is the means by which we come to know Christ. We encounter Christ through encountering at least the truths, if not the very words, of Scripture (John 5:39), and it is in knowing Christ that we know the Father (John 14:9).

As well as being the instrument by which we know Christ, Scripture also has a determinative effect on the rest of our theology. Sola Scriptura describes the way in which we know God, and our view of how we know God will determine what we think on all other theological questions. Sola Scriptura expresses the understanding of authority and method that shapes the rest of Protestant theology.

3 John Jewel, An Apology, or Answer, in Defence of the Church of England, in The Works of fohn fewel, ed. John Ayre for the Parker Society (Cambridge: Cambridge University Press, 1848), 56. 
Why should Christians submit to the authority of Scripture? Because Jesus Christ himself modeled that submission in his prophetic office as revealer of God the Father. The authority of Scripture and the authority of Christ come together. In the Gospels, Jesus repeatedly rebukes a variety of opponents by asking them, "Have you not read?" or "Is it not written?" $\mathrm{He}$ corrects the Sadducees: "You are mistaken, not knowing the Scriptures nor the power of God" (Matt 22:29). He affirms that "the Scripture cannot be broken" (John 10:35). And he resists the temptations of Satan by taking a stand on biblical texts (Matt 4:4, 7, 10). Jesus understood the words of Scripture to be the very words of God. In the Gospels he ascribes words to God himself that in the Old Testament are not presented as words of God (for example in Matt 19:4-5). He bases arguments not only on the words but even on the smallest letters of the Hebrew alphabet. In Matthew 22:43-45 he uses Psalm 110:1 to prove that he is "Lord" by noting that David says " $m y$ Lord," a meaning conveyed by the tiny consonant that is the Hebrew pronominal suffix. John Murray rightly concludes that in debating the authority of the Bible it is not the Bible so much as the authority of Jesus that is at stake: "The integrity of our Lord's witness is the crucial issue in this battle of the faith." 4

In one sense this point was not part of the debate with Rome at the Reformation. Rome professed belief in the inspiration and authority of Scripture; it is more a characteristic of liberal theology to deny the authority and inspiration of the Bible. The point at which sola Scriptura expresses a distinctive of Protestantism is more in its affirmation of the sole final authority of Scripture than in the affirmation of its inspiration. Why do Protestants insist on the unique authority of Scripture? Again, because Jesus did, most notably in his debates with the Pharisees. Like Rome, the Pharisees did not deny the authority of the Scriptures but added to them. Jesus insisted on the unique authority of the written Scriptures over against any additional oral tradition. The only expansion of the Hebrew Scriptures that he authorized was his own teaching and that of his apostles (e.g., John 14:25-26; $15: 26-27 ; 16: 12-15)$. He said nothing at all about extending their authority beyond them to their successors in later generations, nor indeed about who their successors would be. The New Testament itself contains the beginnings of its own recognition as God's word when Peter describes the letters of Paul as "Scripture" (2 Pet 3:16, graphe) and when Paul uses the same term to refer to a text from Luke (1Tim 5:18, citing Luke 10:7). There are subordinate

4 John Murray, "The Attestation of Scripture," in The Infallible Word, ed. N. B. Stonehouse and Paul Woolley, 2nd ed. (1967; repr., Phillipsburg, NJ: P\&R Publishing, 2002), 42. 
authorities in the life of the church such as confessions and catechisms, but they always depend on conformity to Scripture for their weight.

When we speak of the inspiration of the Bible we do not mean that it is a dry, static book, a dull encyclopedia of the divine. Nor do we separate it from God himself, as if it had a life of its own and we might fashion an idol out of it. Rather, as the God-breathed word, the Bible is the living voice of God himself, his love letter to a dying world. The Bible itself speaks of the life-giving power of the word of God, for example in Psalm 33:6:

By the word of the LORD the heavens were made, And all the host of them by the breath of His mouth.

Here God's word and his breath are paralleled, as they are in 2 Timothy 3:16, when Paul says that "all Scripture" is "God-breathed." God's breath has creative power: it gives life to Adam (Gen 2:7) and to spiritually dead Israel (Ezek 37:9-10). This is why the Bible needs no authority beyond itself: it comes with all of God's power. As the voice of God it self-authenticates. Who would dare claim to authenticate it, as if God's authority needed to be propped up by another? The apostles and prophets founded the church, not the church Scripture (Eph 2:19-22). As Luther asks, "who begets his own parent?"5

The idea of the self-authenticating authority of Scripture is not a circular argument, contrary to what many, even Protestants, say. Circular arguments are bad arguments, since they have no resting point, no firm foundation. By contrast, the appeal to the self-authenticating authority of Scripture is an argument from a final first principle: God in his word. All systems of thought either have no first principle (being circular), or they have some such first principle; there is no shame in it. For the Protestant, the first principle is God in his word.

Is there not, however, a problem with knowing what Scripture means and how we are to understand it? Do we need an authoritative interpreter? To think so is to imply that Scripture lacks sufficient power and clarity. But the Bible teaches its own active authority. It is the voice of God. Who would dare to tell God that he has not spoken clearly? Nor does the multiplication of voices actually help to narrow the range of interpretations. We only need to observe heated debates among Roman Catholic theologians concerning the role of tradition or non-Christian religions to realize that the plurality

5 Martin Luther, The Babylonian Captivity of the Church, in Three Treatises (Philadelphia: Fortress, 1970), 238. 
of texts in Denzinger has not made Rome's total theology any clearer. ${ }^{6}$

Note, however, that the Bible teaches sola but not nuda Scriptura. The unique final authority of Scripture does not mean that I could achieve my best theology if I could just get away from everyone else, leaving behind two thousand years of reflection on the text. It is obvious that the catholic (i.e., universal) church has deepened its grasp of biblical teaching on such doctrines as the Trinity, the incarnation, and justification. Only a madman would want to leave all that behind.

\section{Solus Christus}

In the order of our knowing, the message of Scripture comes first. In the order of being (the ordo essendi) the first place is unassailably occupied by the Lord Jesus who is first and last ( $\operatorname{Rev} 1: 17)$. He is the one through whom and for whom all things were created, and in whom they exist (Col 1:16-17). He alone is the "image of the invisible God," the one in whom the fullness of the Father dwells (Col 1:15, 19). Benjamin Warfield, great advocate of Scripture that he was, describes how the revelation in Christ "stands outside all the diverse portions and diverse manners in which otherwise revelation has been given" because Christ "does not so much make a revelation of God as Himself is the revelation of God." In this sense, any account of the solas could rightly reflect the order of reality by beginning with solus Christus.

The uniqueness of Christ is clear when we view his person and work in terms of the three offices of prophet, priest, and king. In the first chapter of Hebrews the Son is described as "so much better than the angels" because he possesses a unique sonship (vv. 4-5), is uniquely worthy of worship (vv. 6-7), and sits enthroned as the king who will endure forever (vv. 8-12). As the book continues, it becomes clear that the uniqueness of Christ is also focused in his priestly work. He alone took on flesh so that he might rescue his brothers. He alone was able to offer a final and sufficient sacrifice and to live forever to make intercession for his people (Heb 7). As Paul writes to Timothy, "there is one God and one Mediator between God and men, the Man Christ Jesus, who gave Himself a ransom for all" (1 Tim 2:5). Jesus himself explains his work as prophet. He alone can make the Father known: "Nor does anyone know the Father except the Son, and the one to

6 "Denzinger" is a common label for the Compendium of Creeds, Definitions, and Declarations on Matters of Faith and Morals, ed. Heinrich Denzinger et al., 43rd ed. (San Francisco: Ignatius, 2012), which extends to around 1,400 pages.

7 Benjamin B. Warfield, The Works of Benjamin B. Warfield, ed. Ethelbert D. Warfield, William Park Armstrong, and Caspar Wistar Hodge, 10 vols. (Oxford: Oxford University Press, 1927; repr., Grand Rapids: Baker, 1991), 1:28. 
whom the Son wills to reveal Him" (Matt 11:27). Only the Son can reveal the Father because they uniquely indwell one another (John 14:9-10).

\section{Sola Gratia and Sola Fide}

To understand the Protestant's delight in being saved by grace alone (sola gratia) through faith alone (sola fide) we have first to grasp his despair of himself. Without a grasp of the doctrine of sin it is not possible to understand the doctrine of salvation: soteriology responds to hamartiology. The Reformers knew this. They realized that when they were dealing with a false understanding of salvation its root lay in the overestimation of human capacity. When Luther writes against Desiderius Erasmus on the condition of the human will, he commends him for homing in on this as "the real issue, the essence of the matter in dispute," "the question on which everything hinges," "the vital spot." "When John Calvin maintains against Rome that a man must find righteousness outside himself because he is dead in sin, he notes that "a controversy immediately arises with reference to the freedom and powers of the will." ${ }^{\prime}$ On this point the Reformers are the true heirs of Augustine, who frequently argued from the bondage of the human will to the sole-sufficiency of divine grace.

This entire tradition echoes the teaching of Paul, who connects the doctrines of sin and salvation, perhaps most notably when he explains to the Christians at Ephesus that they were "dead in trespasses and sins" until God made them alive together with Christ (Eph 2:1, 5). A resurrection is not something to which the one raised contributes; he languishes helpless until God sovereignly breathes new life into him. Paul goes on to state that we are saved by grace as a gift of God and that salvation is not of ourselves but of God (2:8). Indeed, he depicts salvation as an act of creation in Christ $(2: 10)$. As the world was created ex nihilo by the breath of God without a self-determining choice, so we are re-created solely by the gracious work of the Spirit of God: sola gratia.

Sola fide is the proper outworking of sola gratia. It was by no means unique to Luther, and while there are some differences between the Lutheran and Reformed doctrines of justification, there is much common ground. Calvin too held that the doctrine of justification is vital for the life of the church: "The safety of the Church depends as much on this doctrine as human life

8 Martin Luther, On the Bondage of the Will, in Luther and Erasmus: Free Will and Salvation, ed. and trans. Philip S. Watson and B. Drewery (Philadelphia:Westminster, 1969), 333.

9 John Calvin, The Necessity of Reforming the Church, in Selected Works of Fohn Calvin:Tracts and Letters, ed. and trans. Henry Beveridge and Jules Bonnet, 7 vols. (1851; repr., Grand Rapids: Baker, 1983), 1:159. 
does on the soul." ${ }^{10}$ And the Thirty-Nine Articles of the Church of England teach that justification by faith alone is "a most wholesome doctrine."

The exclusion of works from any causal role in justification is a repeated theme in Paul. He teaches in Romans 4 that Abraham could not have been justified by works, since that would have given him something to boast about before God. Righteousness was imputed to David "apart from works" (Rom 4:6), hence by faith alone. The works excluded are not just works done before conversion: Paul quotes Genesis 15, from the time after the patriarch responded to God's call in chapter 12, and the words of David (from Ps 32), who had known God from the womb (Ps 22:9-10). Scripture excludes as the causal ground of justification even works done after conversion.

A word is needed to guard against two misunderstandings. First, our faith itself is not the moral basis of our justification. Our believing does not justify us by reference to itself, but by uniting us to Christ, whose merit alone justifies us. Second, sola fide is a statement circumscribed in its doctrinal scope. It is not to be applied more widely than the discussion of the meritorious ground of justification. When we deny a role to works, we are denying specifically a role in providing the moral basis of our justification; we are not denying any place for works. Roman Catholics fear that the denial of the merit of works results in moral license, but the place of works is affirmed by Protestant theology. They are the result of our saving union with Christ. As Calvin put it, in Christ we receive the double grace of his justifying righteousness and his sanctifying Spirit, ${ }^{12}$ and as the popular epithet accurately summarizes it, faith justifies alone, but the faith that justifies is never alone.

\section{Soli Deo Gloria}

What is the creation for? Does it have a purpose? If it does have a purpose, does it all have the same purpose? The Protestant answer is that the whole creation is for the glory of God. The world is not about us; it is about the glory of God in Christ. God delights in saving his people for their good, but he does so for his own praise and glory. It is right for God to seek his own praise because he is supremely praiseworthy. Indeed, he must be praised. The perfection of his being so demands that he be glorified that he would be wrong not to glorify himself. Isaiah writes, "My glory I will not give to

${ }^{10}$ Calvin, Necessity, 1:137.

${ }^{11}$ Article 11, in Documents of the English Reformation, ed. Gerald Bray (Cambridge: James Clarke, 1994), 291.

12 John Calvin, Institutes of the Christian Religion, ed. John T. McNeill, trans. by Ford Lewis Battles, 2 vols., LCC 20-21 (Philadelphia:Westminster, 1960), 3.11.1 (1:725). 
another" (Isa 42:8). God is jealous of his glory. It is for him alone and no other. That the Father's purpose is to glorify the Son is a sure sign that the Son himself is God: God does not share his glory with another. The selfglorification of God in Christ is the final purpose of the entire creation.

We must align our own purposes with the overruling purpose of God for his creation: "Whether you eat or drink, or whatever you do, do all to the glory of God" (1 Cor 10:31). The instinct of Protestant theology is therefore to attribute nothing to the creation and everything to the Creator. The first four solas are bound together because they have the fifth as their goal: sola Scriptura emphasizes the glory of the sufficient word of God, solus Christus the unique glory of Christ, sola gratia the glory of God as alone our Savior, and sola fide the glory of the works of Christ rather than our work.

\section{Roman Catholicism before Vatican II}

In response to the Protestant expression of the solas, the Council of Trent clarified and defined Rome's view on these and other issues. From a Protestant perspective, three great problems stand out with Trent: its views of revelation, justification, and worship. The situation was if anything worsened by Vatican I (1869-70). I will outline this historic position before turning to consider developments in the twentieth century.

\section{Revelation}

The brief but dense statement produced by Trent on Scripture and tradition affirms that the revelation of saving truth is contained in two equal sources, the "written books and unwritten traditions." ${ }^{13}$ While some modern Roman Catholic theologians have tried to reinterpret the Council of Trent, the text is clear: the word of God is found in two different forms, written and unwritten. The Council "receives and venerates with the same sense of loyalty and reverence" both the written form and the unwritten form of the word of God. ${ }^{14}$ The Old Testament canon maintained by Trent is not the list of thirty-nine books that would have been used by Jesus himself and was accepted by Josephus and Philo, but includes the writings represented in the Greek Old Testament that were rejected by church fathers such as Origen and Jerome. The unwritten traditions were supposedly dictated orally by Christ or else by the Spirit, and the Council claims that they have been preserved in "continuous succession" since then through the bishops of the

13 "Decree on the Reception of the Sacred Books and Traditions," in Compendium, $\$ 1501$.

14 Compendium, $\$ 1501$. 
Roman Catholic Church. ${ }^{15}$ In other words there is a line of oral tradition from Christ down to this present day that contains no doctrinal innovations but faithfully hands on what Jesus and the apostles taught. When it comes to interpreting the twofold form of the word of God, the Roman Church alone has authority.

To this position Vatican I added the doctrine of papal infallibility, locating the supreme authority for interpreting the word of God in the pope himself. The decree on papal infallibility was defined on July 18, 1870. It declares that the pope is infallible when teaching ex cathedra on matters of faith and practice, that he can teach thus even without the consent of the Church, and that such teachings are "irreformable of themselves, not because of the consent of the Church." ${ }^{\prime 16}$ Even the pope did not claim the right to innovate: when speaking ex cathedra he declares the correct interpretation of the already-given word of God.

\section{Justification}

The Council of Trent does not teach that we can save ourselves by our own effort. It clearly states that divine grace is necessary for salvation. Nevertheless, it does teach that we can cooperate with God in the work of our justification by using the free will that remains after the fall, a free will that has been weakened but not destroyed by sin. In that sense, the Council is semi-Pelagian. According to Trent, faith is only the beginning of justification. Works done in cooperation with the power of the Spirit grow justification so that the justified should be regarded as "having truly merited eternal life."17

\section{Worship}

Archbishop Thomas Cranmer argued that the doctrine of transubstantiation explained why in the Roman Catholic Mass the people would rush from altar to altar to worship the elevated host: "They worshipped that visible thing which they saw with their eyes and took it for very God." ${ }^{\prime 1}$ The doctrine of transubstantiation was defined at the Fourth Lateran Council (1215) and repeated at the Council of Trent:

\footnotetext{
15 Ibid.

${ }^{16}$ Pastor Aeternus, ch. 4, in Compendium, \$3074.

17 "Decree on Justification," ch. 16, in Compendium, $\$ 1546$.

${ }^{18}$ Cited in Eamon Duffy, The Stripping of the Altars: Traditional Religion in England, 1400 1580 (New Haven:Yale University Press, 1992), 98.
} 
By the consecration of the bread and wine, there takes place a change of the whole substance of bread into the substance of the body of Christ our Lord and of the whole substance of wine into the substance of his blood. ${ }^{19}$

This belief forms the basis for Roman Catholic worship of the bread and wine in the Mass, which Trent takes to be the worship of God himself, "the worship of latria that is due to the true God."20

\section{Contemporary Roman Catholicism}

\section{In with the New}

Rome today is not the same as she was in the sixteenth or nineteenth century. Prior to Vatican II the pronouncements of the papacy were increasingly vehement against Protestants, the secular world, and modernizers within the Church (see for example Pius IX's Syllabus of 1864 and Pius XII's encyclical Humani generis of 1950). At Vatican II, however, the Church changed. While Rome is committed to her own form of consistency, and while some Protestant polemics rely on believing that Rome cannot change, the facts of change are clear. A few examples will suffice to introduce the change that has occurred in the last fifty years.

The opening Message to Humanity from Vatican II and Pope John XXIII is unique in the history of church councils for its open greeting to "all men and nations." 21 The tone is immediately different from the anathematizing voice of Trent: the Church "was not born to dominate but to serve."22 The desire of the Council is to foster all that is good, wherever it may be found. ${ }^{23}$ The Church should seek peace more than anyone else, given that she is "the Mother of all."24 The Pastoral Constitution on the Church in the Modern World makes the same point about addressing "the whole of humanity." 25

Traditionally, Rome has insisted that there is no salvation beyond her own bounds: "There is indeed one universal Church of the faithful, outside of which no one at all is saved." ${ }^{26}$ Formally, at least, Vatican II agrees with this sentiment: "The Church, now sojourning on earth as an exile, is

19 "Decree on the Sacrament of the Eucharist," ch. 4, in Compendium, $\$ 1642$; for Lateran IV, see $\$ 802$.

20 "Decree on the Sacrament of the Eucharist," ch. 5, in Compendium, $\$ 1643$.

${ }^{21}$ The Documents of Vatican II, ed. Walter M. Abbott, trans. Joseph Gallagher (New York: Guild Press, America Press, Association Press, 1966), 3.

${ }^{22}$ Ibid., 5.

${ }^{23}$ Ibid.

${ }^{24}$ Ibid., 6.

${ }^{25}$ Gaudium et spes, 2, in Compendium, $\$ 4302$.

26 "The Fourth Lateran Council (1215)," ch. 1, in Compendium, $\$ 802$. 
necessary for salvation." ${ }^{27}$ But in practice, the bounds of salvation are extended beyond the Roman communion. The opening Message calls "not only upon our brothers whom we serve as shepherds" but also to "all our brother Christians." ${ }^{28}$ Here is an acknowledgement of brother Christians beyond the Roman fold. The Council later speaks of how the Church is in many ways "linked with those who, being baptized, are honored with the name of Christian" though they are not in communion with the pope. ${ }^{29}$ This link is specified as the shared work of the Holy Spirit: "In some real way they are joined with us in the Holy Spirit, for to them, too, he gives his gifts and graces whereby he is operative among them with his sanctifying power." ${ }^{30}$ This kind of stance toward non-Catholics explains the booming industry in ecumenical dialogues with other churches that followed Vatican II.

The positive stance extends not only to other Christians, but even to adherents of non-Christian religions:

The plan of salvation also includes those who acknowledge the Creator. In the first place amongst these there are the Muslims, who, professing to hold the faith of Abraham, along with us adore the one and merciful God, who on the Last Day will judge mankind. ${ }^{31}$

We might think that this means only that Muslims are not beyond conversion, but the idea is evidently that they can be saved while remaining Muslims, because the text continues to say of the next group of those who acknowledge the Creator,

those also can attain to salvation who through no fault of their own do not know the Gospel of Christ or his Church, yet sincerely seek God and moved by grace strive by their deeds to do his will as it is known to them through the dictates of conscience. ${ }^{32}$

A second change at Vatican II is a greater emphasis on the role of the college of bishops and the laity in the life and work of the Church, producing a much more "democratic" tone than Vatican I. $^{33}$ In particular, the "secular" work of lay people is endorsed as part of their spiritual work for God: "the laity consecrate the world itself to God." 34

\footnotetext{
27 Lumen gentium, 14, in Compendium, $\$ 4136$.

28 Documents, 6.

${ }^{29}$ Lumen gentium, 15, in Compendium, $\$ 4139$.

30 Ibid.

31 Lumen gentium, 16, in Compendium, $\$ 4140$.

32 Ibid.

33 The term is that of Avery Dulles, in Documents, 12.

${ }^{34}$ Lumen gentium, 34, in Compendium, $\$ 4160$.
} 
A third change in contemporary Roman Catholicism at both Vatican II and in the 1994 Catechism of the Catholic Church is the more exegetically sensitive use of some biblical texts. Trent quotes the Bible constantly, but it does so in ways that make it say what it does not say. Much of the use of the Bible at Vatican II is more accurate, and the Catechism contains sustained pages of exegesis that could pass under the radar of the sharpest Protestant if they were presented without their context. In a related change, Vatican II encourages the laity to read Scripture, requiring that "easy access to Sacred Scripture should be provided for all the Christian faithful." ${ }^{35}$

\section{Out with the Old?}

It will not do to say that Rome is semper eadem (always the same). Any Protestant who insists that there is nothing new in Rome runs the risk of being taken for an ignoramus. Given the undeniable reality of the changes, we must ask how they can be understood. Most importantly, do these new elements mean that the traditional doctrines that offend against the biblical solas have been removed?

Most of the content of pre-Vatican II theology remains entirely intact at the points where it departs most clearly from biblical teaching. The old errors are differently framed and differently voiced, but they remain as they were. There is no movement on the unbiblical elements of the teaching regarding revelation, justification, or worship. This analysis may be sustained by considering the evidence of Vatican II and the 1994 Catechism that was written to disseminate the teaching of the Council. ${ }^{36}$

\section{i. Revelation}

Vatican II presents its own innovations not as changes to the traditional position, but as organic developments of it. This is evident in the teaching on revelation. The Dogmatic Constitution on Divine Revelation echoes Trent: "Both sacred tradition and Sacred Scripture are to be accepted and venerated with the same sense of loyalty and reverence." ${ }^{37}$ Referring to Vatican I, the Dogmatic Constitution on the Church states unequivocally, "All this teaching about the institution, the perpetuity, the meaning, and reason for the sacred primacy of the Roman pontiff and of his infallible Magisterium, this

\footnotetext{
${ }^{35}$ Dei verbum, 22, in Compendium, $\$ 4229$.

${ }^{36}$ Pope John Paul II explains that the Catechism was commissioned in order to bring the work of the Council to the people; Catechism of the Catholic Church (London: Geoffrey Chapman, 1994), 3.

${ }^{37}$ Dei verbum, 9, in Compendium, $\$ 4212$.
} 
sacred council again proposes to be firmly believed by all the faithful."38 And even as Vatican II emphasizes the collegial role of the bishops, it makes them entirely dependent on the pope: "The pope's power of primacy over all, both pastors and faithful, remains whole and intact." 39

\section{ii. Justification}

Despite numerous ecumenical agreements, there has been no magisterial revision of Trent on justification. Indeed, the 1994 Catechism simply reiterates the substance of Trent in a gentler tone, frequently by direct quotation. Justification is defined as "not only the remission of sins, but also the sanctification and renewal of the interior man." ${ }^{40}$ Justification itself entails the sanctification of the whole being. ${ }^{41}$ This sanctification can be sufficient to merit salvation: "We can then merit for ourselves and for others the graces needed for our sanctification, for the increase of grace and charity, and for the attainment of eternal life." 42

\section{iii. Worship}

The Mass remains at the center of Roman Catholic worship. The Catechism quotes Vatican II, saying that the Eucharist is the "source and summit of the Christian life." ${ }^{3}$ It explains that all the other sacraments are "oriented towards" this sacrament, that it is "the Sacrament of sacraments," and that in it is contained "the whole spiritual good of the church." 44 It is "the sum and summary of our faith," "the centre of the Church's life." 45 The Mass is identified even as the "cause" of the Church's communion with the divine life; in other words, it is the action of the Mass which keeps the Church "in being." 46 The Catechism holds that the bread and wine "become Christ's Body and Blood." 47 It uses the words of Trent to say that the change is "fittingly and properly called transubstantiation." 48 It explains that the transubstantiated elements are worshiped with the "adoration" due to God, as opposed to just the "devotion" due to Mary. ${ }^{49}$ The host is therefore to be

38 Lumen gentium, 18, in Compendium, $\$ 4142$.

39 Lumen gentium, 22, in Compendium, $\$ 4146$.

40 Catechism, \$1989, quoting the "Decree on Justification," ch. 7.

41 Catechism, $\$ 1995$.

42 Ibid., $\$ 2010$.

43 Catechism, \$1324, quoting Lumen gentium, 11.

${ }^{44}$ Catechism, $\int \$ 1324,1330$.

45 Ibid., \$\$1327, 1343.

46 Ibid., $\$ 1325$.

47 Ibid., $\$ 1333$.

48 Ibid., $\$ 1376$, quoting Trent, "Decree on the Sacrament of the Eucharist," ch. 4.

${ }^{49}$ Catechism, $\$ 1378$; cf. $\$ 971$ for the distinction from Mary. 
reserved for veneration and carried in procession. ${ }^{50}$ The words of John Paul II are cited in the Catechism: "Let our adoration never cease."

iv. More of Mary

Vatican II also affirms the devotion to Mary that had grown since the Reformation. The Message to Humanity states the credentials of the Council in terms of Mary and Peter: "We successors of the apostles have gathered here, joined in singlehearted prayer with Mary, the Mother of Jesus, and forming one apostolic body headed by the successor of Peter." ${ }^{52}$ Lumen gentium, arguably the most significant reforming text at Vatican II, ends with a section on Mary. Among other things, it affirms that she is "Queen of the universe," "the beloved daughter of the Father and the temple of the Holy Spirit," who "far surpasses all creatures, both in heaven and on earth," "a preeminent and singular member of the Church," "Advocate, Auxiliatrix, Adjutrix, and Mediatrix." 53 Mary cooperates with God in the work of salvation. She was "united with him by compassion as he died on the Cross" and "in this singular way she cooperated by her obedience, faith, hope, and burning charity in the work of the Savior in giving back supernatural life to souls." ${ }^{54}$ For all these reasons, the cult of Mary is to be "generously fostered." 55

\section{Understanding Contemporary Roman Catholicism}

Rome thus still teaches her traditional convictions on revelation, justification, and worship, and she has taken further her exaltation of Mary. And yet alongside all this she has adopted an open and embracing stance. Is the traditional dogma set alongside the contemporary stance in a competition that only one side can win? ${ }^{56}$ Or is there a theological rationale that can identify some kind of coherence to the developments?

In his excellent, persuasive account of the changes in Roman Catholic theology, Leonardo De Chirico argues that the new stance is explained by developments in Roman Catholic treatments of the relationship between nature and grace. ${ }^{57}$ The traditional position, derived from the medieval

\footnotetext{
${ }^{50}$ Ibid., $\$ 1378$, quoting Paul VI in Mysterium fidei, 56.

${ }^{51}$ Catechism, $\$ 1380$, citing Dominicae cenae, 3 .

52 Documents, 3.

53 Lumen gentium, 59, 53, 62, in Compendium, $\$ \$ 4175,4173,4177$.

${ }^{54}$ Lumen gentium, 61 , in Compendium, $\$ 4176$.

${ }^{55}$ Lumen gentium, 67, in Documents, 94.

56 This is the reading favored by David Wells in Revolution in Rome (London:Tyndale Press, 1973).

${ }^{57}$ See Leonardo De Chirico, Evangelical Theological Perspectives on Post-Vatican II Roman
} 
scholastics, was that the realms of nature and grace are strongly to be distinguished. The distinction was traced back even to the created state of Adam. Thomas Aquinas believed that man was created with a natural human goodness as part of the image of God, to which was added another kind of goodness, a supernatural gift of grace (which came to be known as the donum superadditum). Though it was given at the time of creation, the donum was not part of created nature. ${ }^{58}$ Thus Thomas distinguished sharply Adam as a natural man from Adam as a man graced by God.

ForThomas, fallen man therefore retains many natural created capacities still intact. The natural inclination to virtue was "diminished by sin" but not destroyed. ${ }^{59}$ Only the donum was entirely destroyed. This is why reason can play such a significant role for Thomistic Catholicism: fallen man retains a considerable natural capacity for reasoning correctly. God, Aquinas believes, can be known by natural men and even loved by them. Indeed, in one sense, he is loved by all: "God, in so far as He is the universal good, from Whom every natural good depends, is loved by everything with a natural love." ${ }^{60}$ Natural law can be a viable guide for fallen creatures, since they retain "a natural inclination to know the truth about God, and to live in society." "Man thus has a twofold happiness, one "proportionate to human nature" attained through natural virtue, and one "surpassing man's nature" attained by God's grace through the theological virtues of faith, hope, and love. ${ }^{62}$ Later Thomists took this position even further. Some of them, especially Thomas Cajetan, argued that there is a realm of pure nature (natura pura) that does not need the supernatural to find its goal, but has its own proper end in the natural realm itself. This development of Thomas's position, which goes beyond his own view that nature could never find its proper end in itself, produced a very strong nature-grace contrast. Grace was firmly contained within the supernatural realm alone, and nature was sufficient to itself. Given such views, we can see why Trent was so insistent on the unique place of the Church as the repository of supernatural grace. Rome's aggressive anti-Protestant and anti-Enlightenment stance stemmed from the conviction that only she was the realm of grace.

Catholicism, Religions and Discourse 19 (Bern: Lang, 2003), passim. I am greatly indebted to this work for my understanding of the theology of Vatican II.

58 Thomas Aquinas, Summa Theologica, trans. Fathers of the English Dominican Province, 5 vols. (1948; repr., Westminster, MD: Christian Classics, 1981), Ia IIae 112.1 (hereafter, $S T$ ).

${ }^{59}$ Aquinas, $S T$, Ia IIae 85.1, 2:966.

${ }^{60}$ Aquinas, $S T$, Ia $60.5,1: 301$.

${ }^{61}$ Aquinas, $S T$, Ia IIae 94.2, 2:1009.

${ }^{62}$ Aquinas, $S T$, Ia IIae 62.1, 2:851. 
Even though Thomas's Summa was enjoined as the basis of theological training by Leo XIII in 1879, twentieth-century Roman Catholicism increasingly challenged the later Thomistic views of the nature-grace antithesis. G. C. Berkouwer and others have drawn attention to the impact of the nouvelle théologie (new theology) of French Catholic theologians in the 1940s and 1950s. Their teaching explains the improved use of the Bible compared to Trent because they emphasized ressourcement, a return to the Bible and the church fathers. But they also stand behind the changed stance of Vatican II toward non-Catholic churches and the non-Christian world.

Theologians like Henri de Lubac led the transformation of Rome's attitude. His most controversial work focused on the nature-grace issue. He argued against the later Thomists that nature itself always seeks its fulfillment in grace. He made the case most notably in his 1946 work Surnaturel, and with more circumspection in The Mystery of the Supernatural (1965). While he is clear that fallen nature itself is not penetrated by supernatural grace, he has a much more spiritual account of created nature than the later Thomists, and in some respects than Thomas himself. Where later Thomists denied that in pure nature there is a natural desire for God, de Lubac argues for a strong desiderium naturale in man.

The influence of this new theology of nature yields a whole new picture of the Church and its relationship to nature. Nature, even fallen nature, is viewed as always looking for God. If nature is like that, then the Church may take an embracive view of human religious phenomena, drawing men from other religions gently and gradually into her own body. Rather than standing against everyone else as the only repository of grace, Rome can warmly invite a searching world to herself since she is the center of a gracious work of God that nonetheless extends beyond herself. As David Wells describes it, for the new Catholicism "the reality of God has become identified with the reality of the earthly city, the sacred is found in the secular, Christ is in the world." 63

Initially this tendency was strongly resisted. De Lubac was removed from his teaching role, and his books were taken out of circulation in 1950. In the same year Pius XII issued Humani generis, essentially an attack on his position. But de Lubac's fortunes changed dramatically when Pope John XXIII appointed him as a consultant to the theological commission that was preparing for Vatican II. He was later made one the Council's theological experts, and PaulVI made him a member of the theological commission. In 1983 John Paul II made him a cardinal.

${ }^{63}$ Wells, Revolution, 54. 
Other elements of the new theology are also important if we are to understand the changes at Vatican II.Yves Congar, another French theologian, is notable for his influence on the Council's stance toward other Christian churches. In Chrétiens désunis (1937) he argued for real elements of grace among non-Catholic churches. ${ }^{64}$ His theology of tradition was also crucial for enabling the Church to embrace contradictory elements. Rather than viewing tradition as a fixed code of sharp-edged dogmatic statements provided by the Magisterium, Congar redefined it as a living, organic reality embracing the spiritual life itself. Writing in 1964, he explains how the tradition has been passed down "not by discursive means" but by "the concrete experience of life." Its transmission is more like an entire upbringing than discrete moments of instruction. ${ }^{65}$

Such a concept of tradition means that there is room to adapt the interpretation of past definitions of doctrine. A fascinating example of this is Congar's own reading of Trent on Scripture and tradition. He distinguishes the belief of the authors of Trent and their immediate successors from the later theological interpretation of their text. They believed that certain truths were contained in tradition and not in Scripture, but this is not enough to invalidate a different reading which finds the full presence of the truth in both Scripture and tradition. ${ }^{66}$ In short, the text meant one thing then but can be taken differently now: "The historical analysis of the question with its array of quotations must not be allowed to dominate and conceal its real significance." ${ }^{67}$

Like de Lubac, Congar was suspended from his teaching role in the 1950s. But in 1959 the pope appointed him as a theological consultant on the commission preparing for Vatican II. Avery Dulles comments that his influence at the Council "was equal to, and perhaps greater than, that of any other Catholic theologian." ${ }^{68}$ Pope John Paul II made Congar a cardinal in 1994.

On the basis of developments like Congar's concept of tradition, Vatican II sets out a historical, developmental, and provisional conception of the Church: "While she slowly grows, the Church strains toward the completed kingdom and, with all her strength, hopes and desires to be united in glory

\footnotetext{
${ }^{64}$ Yves Congar, Chrétiens désunis: Principes d'un "cecuménisme” catholique (Paris: Cerf, 1937), translated as Divided Christendom: A Catholic Study of the Problem of Reunion, trans M. A. Bousfield (London: Bles, 1939).

${ }^{65}$ Yves Congar, The Meaning of Tradition, trans. A. N. Woodrow (San Francisco: Ignatius, 2004), 22.

${ }^{66}$ Ibid., $40-43$.

${ }^{67}$ Ibid., 43.

${ }^{68}$ Ibid., vii.
} 
with her King." ${ }^{\prime 9} 9$ The Church must change in order to mature toward glory. Vatican II teaches that even the word of God is not complete yet in the Church: "As the centuries succeed one another, the Church constantly moves forward toward the fullness of divine truth until the words of God reach their complete fulfilment in her." ${ }^{70}$ As she matures, the Church can blend together elements in her tradition that others regard as incompatible, waiting for them to synthesize into a whole. As Hans Urs von Balthasar states, "Catholic thinking remains open, indeed its special characteristic is that it tends to keep opening up even more." either-or way in which evangelicals view Rome's innovations with the bothand way in which Rome herself sees them. Rome, he maintains, has "sufficient cognitive equipment" to hold together contradictory theological positions. ${ }^{72}$

It is vital to note that Rome's new openness is a prelude to drawing all elements of grace in toward herself. While she views the "separated brethren" more positively, they are expected to move toward communion with the true Church. For all the gentler tone, Rome has not weakened her self-identification as the proper locus of divine grace. As De Chirico argues, she emphasizes catholicity, reaching out to all, and yet also Romanitas, drawing all in to communion with Peter, where the divine life is fully to be found. ${ }^{73}$

The Church is understood to be the place where humanity and divinity properly meet. God and man meet first in Christ, the God-man, and now in the Church. Vatican II compares the Church's existence, "by no weak analogy," to the incarnation. The Church is so like Christ that the 1943 encyclical Mystici corporis states that the Church "is, as it were, another Christ [quasi altera Christi persona]." ${ }^{.74}$ This teaching leads De Chirico to speak of "the theandric constitution of the Church." 75 The Church as the continuation of the incarnation is the presence of Christ in the world. It is therefore the sole vehicle for the full mediation of grace to nature. De Chirico comments, "That mediation is the theological raison d'être of the Roman Catholic Church per se and the chief role of the Church within the wider Roman Catholic system." 76

The Roman Catholic Church of Vatican II therefore sees herself as a centripetal reality in the world, the goal toward which all who realize their

${ }^{69}$ Lumen gentium, 5, in Compendium, $\$ 4106$.

${ }^{70}$ Dei verbum, 8, in Compendium, $\$ 4210$.

${ }^{71}$ Cited in De Chirico, Perspectives, 200.

${ }^{72}$ Ibid., 82.

${ }^{73}$ Ibid., 193.

${ }^{74}$ Compendium, $\$ 3806$.

75 De Chirico, Perspectives, 257.

${ }^{76}$ Ibid., 247. 
inclination toward God are drawn. Lumen gentium states that the "many elements of sanctification and of truth" found outside the Church are "gifts belonging to the Church of Christ" and "forces impelling toward catholic unity." 77 The work of the Church in the world is to take up and refine the good found outside her. ${ }^{78}$

\section{Protestant Truth Still Matters}

How then should Protestants respond to the contemporary Roman Catholic Church? I am asking here how Protestant churches should respond to the Roman Catholic Church, not how individual Protestants should respond to individual Roman Catholics. Those two responses will often need to be very different. There are unorthodox Roman Catholics who believe very little of what the Church teaches, both in a more liberal direction and in a more biblical direction. The encouragement given to the laity to study the Bible at Vatican II must, given the power of the word of God, mean that there are more people within some Roman Catholic congregations discovering the truth of the gospel than previously possible. Such individuals need kind nurture in biblical teaching. They need to understand the errors of the Church, but the stance of Protestants toward them as individuals must be one of gentle encouragement. At the levels of ministry and denomination, however, the situation is very different because we are dealing with the Church's official representatives and her defined doctrinal position.

Much of the impulse for ecumenism comes from a sense of increasing cultural isolation. Timothy George speaks of an "ecumenism of the trenches." 79 Compared to an aggressively secular culture, Rome seems close to Protestants on some issues. But it is identity with the gospel, not relative proximity to it, that is the proper basis of unity. We must be confident that the gates of Hades cannot prevail against the church, no matter what enemies she has.

How then should a Protestant view the Roman Catholic Church today? Rome's new open but embracing stance exists alongside the theology of revelation, justification, and worship that was taught at Trent and Vatican I. Some theological changes have rendered Rome's total position incoherent - for example, on the question of salvation for those outside the Church. On that issue the new position simply contradicts the old. But on revelation,

\footnotetext{
${ }^{77}$ Lumen gentium, 8, in Compendium, $\$ 4119$.

${ }^{78}$ Lumen gentium, 17 , in Compendium, $\$ 4141$.

${ }^{79}$ Cited in Mark A. Noll and Carolyn Nystrom, Is the Reformation Over? An Evangelical Assessment of Contemporary Roman Catholicism (Grand Rapids: Baker Academic, 2005), 192.
} 
justification, and worship Protestants have to deal with the ongoing affirmation of the old doctrines and now also the centripetal stance within which Rome holds them.

The historian A. G. Dickens once wrote that the tenuous link between medieval Roman Catholic writings and the gospel "could be demonstrated with almost mathematical precision." ${ }^{80}$ The same is true of the Roman Catholic doctrines of revelation, justification, and worship. At each point, Rome rejects the biblical solas. Scripture is rendered only a partial deposit of the word of God and is subjected to the church. Justifying righteousness is found in the works of the believer. The glory that is due to God alone is wrongly given to the elements in the Mass. On three most crucial questions, Rome departs from Scripture: "How is the mind of God revealed?" "What must I do to be saved?" and "How is God to be worshiped?" Since the doctrine of revelation functions as an engine for all other doctrines, the departure here opens the door to multiple innovations that are not taught in Scripture. The departure on justification fosters a trust in the believer's own works that if followed through fatally shifts his confidence away from Christ and onto himself. The worship of the elements in the Mass is quite simply idolatrous. In trying to prove transubstantiation, Thomas Aquinas himself argues that the substance of the bread cannot remain, because if it did this would mean the elements "could not be adored with adoration of latria." 81 Thomas rightly saw that if the bread remained bread, the worship would be unthinkable. And the bread does remain. Rome is not exculpated by saying it is Christ who is being worshiped, any more than a profession to be worshiping Yahweh excused Israel when she bowed down to the golden calf (Exod 32:5).

At the heart of the problems with Rome's theology is the displacement of Christ by the Church itself and by Mary. It remains Rome, specifically the pope, who is at the heart of the Church's claim to be the center of God's gracious work in the world. Romanitas is as strong as it ever was. Peter (emphasized at Vatican I) and from him the whole Church (emphasized at Vatican II) has assumed the function of Christ. In this precise sense, Rome stands anti Christou, "in the place of Christ." And it remains Mary who takes from Christ his unique place in heaven. Vatican II says that the assertion of Mary's role in our redemption does not threaten the uniqueness of Christ because it "flows forth from the superabundance of the merits of Christ, rests on his mediation, depends entirely on it, and draws all its

${ }^{80}$ A. G. Dickens, The English Reformation, rev. ed. (1967; repr., Glasgow: Fontana, 1988), 17.

${ }^{81}$ Aquinas, $S T$, 3a 75. 2, 5:2442. 
power from it." ${ }^{\prime 2}$ But Christ's is the kind of unique mediation that cannot be shared. Roman Catholic apologists sometimes point out that the Bible itself invites mere men to make intercession, but there is a world of difference between urging a man on earth to pray to the Lord Jesus in heaven and promoting a woman to be Queen of the universe. As solus Christus is in the order of being the first sola, so Rome's failure to yield to Christ his unique place is her most serious error.

I find an analysis of contemporary Roman Catholicism that recognizes the changes within it more troubling than one that attempts to freeze-frame the picture in the 1560s. Rather than observing elements of Rome's departure from the gospel in a piecemeal atomistic fashion, understanding the dynamic within Vatican II Catholicism highlighted by De Chirico opens our eyes to her entire global project. A more peaceful political and social relationship between Roman Catholics and Protestants is greatly to be appreciated given the tragic history of bloodshed. Nevertheless, Rome remains fundamentally acquisitive of what she regards as her own. I am not implying that there is anything underhanded about Rome's stance, as if it were a cunning popish plot: she is perfectly plain in her official documents about how and why she conducts her relations with Protestants as she does. If we miss this, or willingly occlude it, it is our fault. Rome tells us frankly that the elements of grace that exist outside her are on the move: moving toward her, propelled by their own inner reality to rejoin the Mother of all humanity by submitting to Peter's successor in Rome. De Chirico describes how the Church is "programmatically searching outside its circle for whatever can enrich and expand it." ${ }^{33}$ Given her departure from the biblical solas, it is a search by which we must determine not to be found.

${ }^{82}$ Lumen gentium, 60, in Compendium, $\$ 4176$.

${ }^{83}$ De Chirico, Perspectives, 235. 



\section{What Has Mussolini to Do with Hus?}

\section{CARL R. TRUEMAN}

\section{Introduction}

1

$\mathrm{n}$ this lecture to celebrate the launch of Unio cum Christo I propose to look at how the Italian fascist dictator Benito Mussolini approached the life and thinking of John Hus. ${ }^{2}$ It is no real surprise to find that someone like Mussolini would appropriate a figure like Hus. If you travel to Europe today, in Germany many statues of Martin Luther are on view, almost all from the nineteenth century. The rise of German nationalism fueled interest in Martin Luther, and in nineteenth-century Europe generally there was a renewal of interest in earlier European figures. So it is not surprising that a public figure like Mussolini would be interested in an historical figure like Hus. It fits in with the pattern, on a more sophisticated level, that debates in important streams of thinking in the twentieth century take place through dialogue or in appropriation of past events. In discussions of the English Civil War, for example, in debates between the likes of Christopher Hill and Conrad Russell, the question as to whether the English Civil War was the last of the great wars of religion or the first of the class

1 This article is a revised transcription of the lecture given on October 20, 2015, at the launch of Unio cum Christo at Westminster Theological Seminary, Philadelphia. The oral tone of the original has been largely respected.

2 Benito Mussolini, fohn Huss: the Veracious (New York: Italian Book, 1939). Giovanni Huss il Veridico was published by Podreca and Galantra in Rome in May 1913, translated into English in 1929, and republished in 1939. For more details on the topic, see Pavel Helan, "Mussolini Looks at Jan Hus and the Bohemian Reformation," trans. Zdeněk V. David, Bohemian Reformation and Religious Practice 4 (2000): 309-16. 
revolutions had implications for the understanding of Marxist theory. ${ }^{3}$ This goes back to one of the influential nineteenth-century histories of the peasant war by Friedrich Engels, who plundered the sixteenth century for insights, or propaganda, in order to prop up his and his colleague Karl Marx's view of history. ${ }^{4}$ We are familiar with philosophers using history to provide strength to the narrative of their analyses or perhaps, most influentially at the moment, Charles Taylor, the Roman Catholic sociologist, for whom the late medieval period and then the Reformation is a turning point in the development of the secular mindset. ${ }^{5}$ So to find an important twentieth-century political actor engaging with a theological figure from the past is neither unusual nor unexpected.

Why does Mussolini do it? To answer that question I propose to first of all give a brief life of Hus, which is not as familiar as the life of Luther, because a high percentage of academic Reformation courses focus on Luther.

\section{The Life of Hus}

A brief life of Hus (1369-1415), who was executed six hundred years ago, will illustrate how Mussolini came to use him. ${ }^{6}$ Hus was a Bohemian educated at the University of Prague; he took his B.A. in 1393 and his M.A. in 1396, and in 1400 was ordained a priest. In 1402-1403 he served as Rector of the University of Prague at a time when it was about to be plunged into what we would call now serious ethnic strife, or certainly political strife. At roughly the same time, Hus became preacher at Bethlehem Chapel in Prague, which you can still visit. And interestingly enough, the communists never got rid of the signs of Hus, the statues, in Prague. Hus is appropriated by Mussolini as much as a figure of socialist significance as of anything. Four aspects of Hus's life are particularly relevant to understanding him.

3 See for example, Christopher Hill, Puritanism and Revolution: Studies in Interpretation of the English Revolution of the 17th Century (London: Secker \& Warburg, 1965); Conrad Russell, The Causes of the Civil War: The Ford Lectures Delivered in the University of Oxford (New York: Oxford University Press, 1990).

4 Cf. Friedrich Engels, The German Revolutions: The Peasant War in Germany, and Germany: Revolution and Counter-Revolution, ed. Leonard Krieger, Classic European Historians (Chicago: University of Chicago Press, 1967).

5 Charles Taylor, A Secular Age (Cambridge: Belknap Press of Harvard University Press, 2007), 77-88, 243-44, 264-67.

6 For more details on Hus's life, see Daniel Bergèse, "Jan Hus: A Reformation before the Reformation," Unio cum Christo 1.1-2 (Fall 2015): 61-76. 


\section{Oxford and Prague}

First of all, he was part of a movement within the University of Prague that was inspired by the close connections that had developed between Bohemia and England in the late fourteenth and early fifteenth centuries. Richard II, the ill-fated king of England, married Anne of Bohemia of the House of Luxembourg, the eldest daughter of the Holy Roman Emperor Charles IV, in 1382. The diplomatic relations thus forged facilitated the transfer of intellectual talent and property between the University of Prague and Oxford University, the latter of which in the fourteenth century was dominated by the thinking of the realist philosopher John Wycliffe. In popular Protestant hagiography, Wycliffe is often presented as a proto-Reformer, which is problematic because it represents a considerably anachronistic analysis of him. But Wycliffe's work was marked by a number of things that were to be of significance for the University of Prague in general, and for Hus in particular.

First of all, Wycliffe had a critical approach to the Lord's Supper that was in many ways more consistently Aristotelian than one finds in the doctrine of transubstantiation. For Wycliffe, if the accidents of a substance were present, then the substance itself had to be present as well. His interest on that point derives from an epistemological concern that if the accidents of something are present without an underlying substance a radically skeptical epistemology is implied. The world could simply be a bundle of accidents with no underlying relevant substance, which would be lethal for transubstantiation. Wycliffe's own view of the Lord's Supper appears to have approximated something like what Luther later advocated, where the substance of the bread and the wine and the substance in the body and blood are both present in the elements. The difference between Wycliffe and Luther is that Wycliffe was working on philosophical premises, attempting to apply a purified form of Aristotelianism, whereas Luther repudiated philosophy and simply set forth an article of faith. ${ }^{7}$ There are superficial similarities, but underlying significant differences. The question of whether Hus holds to Wycliffe's position on the Lord's Supper is debated. Certainly he was condemned for it. But it is unclear whether Hus advocated Wycliffe's position or whether he merely expounded it in the University of Prague. Certainly, Wycliffe had an impact on Hus.

Secondly, Wycliffe brought to bear a radical emphasis on predestination that would be crucial for Hus, a quintessential medieval figure in that he

\footnotetext{
7 Cf. Carl R. Trueman, Luther on the Christian Life: Cross and Freedom (Wheaton, IL: Crossway, 2015), 39, 57.
} 
did not believe that any individual Christian could have assurance of faith short of a direct revelation from God. He held to a radical understanding of predestination, and this became a critical tool for undermining the authority of the visible church. For Hus, if you cannot know that you are predestined (and the church is the totality of the predestined), then the pope can make no claim to be head of the church. The pope cannot know he is part of the church and therefore his power is pulled out from under him. ${ }^{8}$

What is perhaps most significant concerning the impact of Wycliffe in Prague is that within the University, profoundly divided between the Bohemians, the Bavarians, the Saxons, and the Poles, he gave the Bohemian faction, of which Hus emerged as the most significant figure, a theological idiom for expressing their identity and their differences from the other parties.

The struggle in the University came to a head in 1409 when King Wenceslas gave the Bohemian faction three votes in determining University policy and one each for the Bavarians, the Saxons, and the Poles. So essentially, Wenceslas handed significant power to the Bohemians. Hus is to be understood against the background of the ethnic struggle, and that hints at one of the ways that he will appeal to Mussolini; it is not difficult to appropriate a figure of nationalism (even though nationalism is a creation of post-Napoleonic Europe) and read back into history with relative ease.

\section{The Crisis of the Papacy}

The second factor that shaped Hus's life was the crisis of the papacy. In 1409 the Council of Pisa elected Alexander V as pope. The other popes at the time, Gregory and Benedict, refused to acknowledge him. The pressing problem in Western Europe at this point was the stabilizing of the church. Who appoints the pope? Who is the legitimate pope? Hus and the Bohemians gave their allegiance to Alexander, who, despite this, issued a papal bull to proceed against Wycliffism in Prague. Alexander died in 1410 and was succeeded by John XXIII, one of three to have held that title in history, the last being the pope of the Second Vatican Council. (The first was the fictional Pope Joan of the Middle Ages, recognized to be woman apparently by giving birth while sitting on the papal throne, who pops up in Hus's writings, since he believed it to be true.) John XXIII launched a crusade against the rival Pope Gregory and those who sought to protect him. He raised an indulgence to finance this action, which became a focal point of Hus's preaching and criticism.

\footnotetext{
8 On Hus and the Leipzig debate, see Trueman, Luther on the Christian Life, 41-42.
} 


\section{Council of Constance}

The third factor was the Council of Constance. Hus and his ideas had gained significant influence by 1412, but he had failed to find decisive support in either the king, the pope, or the council. His language shifted at this point, making direct appeals to Christ as an authority. It is not surprising, for this reason, that Luther saw an earlier kindred spirit in Hus, as the Hus of 1412 was not dissimilar to the Luther who emerged in 1517. When Luther realized that neither the papacy nor the councils were going to come to his support, he was forced to reflect upon the issue of authority that underlay his protest without him realizing it. In 1412, Hus began to reflect significantly on the issue of authority.

In the wider sphere, however, in 1414 the empire decided to convene the Council of Constance, which ran for four years, in order to end the crisis of the papacy. Wenceslas's brother, Sigismond, king of the Romans and functional ruler of the empire, summoned Hus to attend the Council of Constance under safe conduct. In popular Protestant hagiographical accounts, that Hus was given a safe conduct to the Council where he will be arrested, tried, and executed is one of the great scandals. However, there are strong pointers that Hus knew the safe conduct was not to be trusted and he even fixed his last will and testament before departing for the Council. In the medieval context, everybody knew that the safe conduct would not be worth the paper it was written on: he went, was arrested, tried, and executed on a series of charges of heresy. Subsequently Bohemia would erupt in war, a war that only ended in 1436 at the Council of Basel. So Hus, a significant, provocative theological and political figure in his day, perished at the stake, but his significance in some ways lies in what happened afterwards, as is often the case in church history: the way figures are appropriated by later tradition makes them significant.

\section{Luther and the Significance of Hus}

Before we address Mussolini's approach, it can be pointed out that the significance of Hus has come primarily through Luther. Legend quickly grew up as to how, as Hus was being burned at the stake, he made a prophecy to the effect of "Today you burn a goose, but a hundred years from now a swan will arise." ${ }^{\prime}$ Luther was very enamored of this prophecy. He definitely saw himself as a Hus-like figure. In Lutheran churches today the lectern is often in the shape of a swan, an aesthetic allusion to Luther's appropriation of this legendary prophecy about a swan that was to rise a hundred years

9 Hus is similar to the Czech word for goose, husa, and Hus is supposed to have played on this ambiguity. 
hence. Hus was burned in 1415 , and Luther came into the national/international limelight in 1517-1518, almost exactly one hundred years later. So there is a certain symbolic significance. Luther, of course, even though he was cautious not to identify himself with the fulfillment of biblical prophecy, generally liked to be seen as the fulfillment of positive prophetic figures.

Hus becomes pointedly significant in the Luther story at the Leipzig Disputation in 1518. The University of Leipzig had historical links with the University of Prague and the Bohemians. Indeed, after the Kutná Hora decree handed power in the University or Prague to the Bohemians, there was a mass exodus of students and academics from the other ethnic or linguistic groups to Leipzig; and out of that exodus the University of Leipzig was born. So not only would Hus's temporary triumph at the University of Prague lead to the founding of the University of Leipzig, but also Hus would become a bone of contention in Leipzig at the time of the Reformation.

At Leipzig Luther chose to preach the night before the Disputation on Matthew 16:18, a provocative text to choose, on Jesus's commission to Peter and the promise that the church would not fail. Luther preached in a manner that emphasized that the church is the place where the Holy Spirit dwells and is not identified with a particular institutional hierarchy. Johann Eck, probably one of the sharpest scholastic minds and one of the best debaters of his generation, set the scene for the debate that night. Leaving the lecture theatre where Luther had delivered his sermon, and having heard Luther preach, he was reputedly heard to say, "That is completely Bohemian." Eck was already making a connection between what he heard from Luther and what Hus said at the beginning of the fifteenth century, the significance being that Hus had been condemned as a heretic. If Luther walks into the "Hus trap" in the Leipzig debate, then Eck has the upper hand; if Luther backs somebody already condemned as a heretic, then it is the endgame, and that of course is what Luther did. Luther was lured by Eck into identifying himself with Hus. He describes Eck at one moment in the debate this way:

Then, coming to the last point, he [Eck] rested his case entirely on the Council of Constance which had condemned Huss's article alleging that papal authority derived from the emperor instead of from God. Then Eck stamped about with much ado as though he were in an arena, holding up the Bohemians before me and publicly accusing me of the heresy and support of the Bohemian heretics, for he is a sophist, no less impudent than rash. These accusations tickled the Leipzig audience more than the debate itself. ${ }^{10}$

${ }^{10}$ Martin Luther, "The Leipzig Debate, 1519," trans. Harold J. Grimm, Luther's Works (Philadelphia: Muhlenberg, 1957), 31:321-22. 
What Eck proceeded to do at Leipzig was to press Luther on the issue of authority: "So Luther, the papacy's got it wrong. So Luther, now you are saying the Council of Constance made errors, and Councils can't help us in terms of authority, so where do you place the issue of authority, Luther?" Hus in 1412 wrestled with the same problem as Luther before Eck in 1518 at Leipzig. Hus is significant for Luther because he exposed the novelty of papal authority and the issue of authority underlying the debate as a whole, as in Matthew Spinka's work, where Hus emerges as a Czech hero. ${ }^{11}$ Of course, during the immediate post-war era Czechoslovakia was a satellite of the Soviet Union, at times under Soviet occupation, and Hus became a hero of Czech nationalism.

\section{Mussolini’s Interest in Hus}

Mussolini was not a Bohemian, so what was his interest in Hus, and why, in 1912-1913? The English title of his work Giovanni Hus, il veritico, "John Hus, the Veracious" (and not the voracious, even if Mussolini was voracious!). Hus had in fact featured a couple of times previously in Italian nationalist history. ${ }^{12}$

Giuseppe Garibaldi, the father of modern Italy, was invited in 1869 to attend a celebration of the quincentenary of Hus's birth in Prague. Though we have a letter from Garibaldi declining the invitation, that he was invited is interesting, because 1869 is the year of post-Napoleonic nationalism in Europe, when the nation-state was being forged. Garibaldi was one of the key men in that story. And it is obvious that there was something of a network in Europe. Different national movements were connected with each other. As the Czechs were pressing for nationhood, so the Italians were. So, one of the ways in which Hus made his way back into common political discourse in the nineteenth century was through nationalism.

The other impulse is free thinking. At the heart of Rome stands a statue commemorating Giordano Bruno, and on certain days the local atheists and free thinkers lay wreaths at the statue of Bruno, a Dominican, a scientist, a kind of Galileo figure. He developed theories about the planets and the stars and was also ultimately tried and executed by the church for heresy, not for his understanding of planetary circulation. But in the nineteenth century, Bruno was appropriated by the burgeoning free-thinking movement

${ }^{11}$ Cf., e.g., Matthew Spinka, Fohn Hus: A Biography (Princeton: Princeton University Press, 1968); fohn Hus at the Council of Constance (New York: Columbia University Press, 1965).

${ }^{12}$ For Hus's reception in Italy, see now Lothar Vogel, "Die Rezeption und Wahrnehmung von Jan Hus in Italien," Communio viatorum 57.1 (2015): 53-70, esp. 59-61 on Mussolini. 
and became a hero of freedom of conscience. His statue in the Campo de' Fiori, like those of Luther in Germany, is a nineteenth-century tribute to free thinking. On the statue there are other figures carved, and one of them is Hus. So in the nineteenth century Hus was appropriated in two ways: as a figure of nationalist importance and as a figure of free thinking. Both are anachronisms because Hus was neither a free thinker nor really a nationalist. The background of Mussolini's interest in Hus is not a particularly theological one; Hus would have been known to Mussolini because he was a nationalist and a free thinker.

In 1911 before he became a fascist, Mussolini was a Marxist and a socialist. He only made his move to fascism during the First World War in a break with the Socialist Party over support for the war. Mussolini was initially opposed to the First World War but then broke with the party line and became a supporter of the war, which is the critical moment in his political development. At that time he was still a socialist and in close contact with the international organization of free thought. The Czech division of this organization decided that it would hold its 1915 meeting, three years hence, in Prague, on the five-hundredth anniversary of the burning of the great champion of free thought, John Hus. It appears that Mussolini was either commissioned or decided that it would be a good thing to write a book on Hus which he could then take to the conference in Prague. Of course, the conference never took place, because the First World War intervened. In 1911-1912 Mussolini also happened to be in prison for five months after inciting riots against the Italian war in Libya, a not-uncommon thing for him, as he was a real rabble rouser. Subsequently, he wrote the book as an expression of his commitment to free thought. However, something more than free thought and socialism emerge in this book, which represents a significant turning point in Mussolini's thinking.

\section{Contours of Mussolini's Analysis}

The book is relatively short, in translation about 150 pages. It is heavily dependent on secondary literature, rather than a reading of Hus's own sources, and it contains a number of errors as well, the most obvious being that Mussolini seemed to think that Wycliffe was executed for heresy (a reasonable assumption for the fourteenth century-if you are a notorious heretic you will get executed for it). In fact, Wycliffe died relatively peacefully, but after the Council of Constance he was exhumed and burned at the stake. Chapter 1 is significant for seeing where Mussolini is coming from and focuses on the corruption of the church in the fourteenth century, 
which will contribute to the interesting afterlife of the book during Mussolini's dictatorship. Chapters 2 and 3 deal with Hus's life, work, and death, while chapter 4 focuses on his writings and, interestingly enough, mostly on On Simony, an economic study criticizing the corruption rife in the church. ${ }^{13}$ The fifth chapter is on the Hussite wars, and Mussolini interestingly distances himself from Hus, considering them far too violent, and comments that the Hussites became as bad as the church. Mussolini is not a "violence for violence's sake" man. The sixth chapter is a repudiation of the Roman Catholic Church's negative views of Hus. Finally, there is an appendix, in which Mussolini provides a translation of Luther's preface to Hus's letters with excerpts from nineteen letters. A number of interesting themes emerge.

\section{Socialism}

Hus, in this work, emerges less as a figure of national significance and more as a mouthpiece for the ordinary man. When Mussolini rereads Hus's work, what he sees is a charismatic union organizer. On page 17 of the translation, he says, "In fact every heresy disclosed a social content, at times socialistic." ${ }^{14}$ This hints at Mussolini's Marxist background: "The heretics spoke to the people and for the people," and "John Hus, the Veracious," is il veritico. One of Mussolini's favorite journalistic pseudonyms was "vero heretico," which sounds similar, meaning "true heretic." Mussolini clearly regards heresy as an idiom of socialist protest.

\section{Mysticism}

Having said that the socialism is more prominent, nationalism is also in evidence. There is a kind of mysticism at work in this book, a mysticism that transforms Mussolini's socialism and that often characterizes Marxist historiographies: mysticism is the key to revolution. Hus is inspired by a deep profound mysterious idea. Revolution requires religious fervor, built on a kind of mythology, which is certainly present at the start of the twentieth century. Marxism changed in the mid-twentieth century, but certainly the idea that religion was an inherently pacific thing was strong in Marxism at the start of the twentieth century. Mussolini clearly considers that religion has a powerful and pungent social revolutionary activist aspect. And the mythology that he sees in Hus has a distinct national dimension to it. $\mathrm{He}$ finds in Hus both religious fervor and a sense of nationhood. In other

\footnotetext{
${ }^{13}$ For an English translation of this work, see Jan Hus, "On Simony," in Advocates of Reform, ed. Matthew Spinka (Philadelphia: Westminster, 1953), 196-278.

${ }^{14}$ Mussolini, fohn Huss, 17.
} 
words, Mussolini is moving towards fascism, and will be a fascist within five or six years. ${ }^{15}$ Written at a point before he breaks with the Socialist Party, this analysis offers an interesting and unconventional insight into religion that is significant for his later thinking.

A naive assessment of Marxist socialism might describe it as an eschatological movement. It looks forward to the New Jerusalem, which is why it had a strongly industrial aspect to it. While they are proud of Fidel Castro, Marxists tend to look down on rural ways of life. It was an industrial movement that looked forward to the end of history. Fascism, by contrast, is a protological movement. It looks backward to Eden, to the myths of national origins and foundations, and it often has an agrarian aspect. That emerges in Mussolini's presentation of Hus: it is socialist but with a transformation that will have significance for the twentieth century. Secondly, it is anticlerical from the outset, presenting a negative view of the church. And the big question in Italian politics, post Garibaldi, is always, What is the relation with the church? It continues today with issues of crucifixes in classrooms. The Catholic Church is powerful politically in Italy, and the question in Mussolini's day was always, What is the relationship between state and church? This book is part of Mussolini's polemic against the power of the church, which will make the afterlife of this book interesting.

\section{The Great Man}

Thirdly, we see here the emergence of the idea of the great man. Hus is presented throughout as the great virtuous seeker after truth, and there is no doubt that Mussolini sees himself identified in that figure. Hus in the subtitle is termed veritico, which sounds very much like vero heretico, and the verbal similarity of the pun probably amused Mussolini, who as a socialist saw himself as the heretical opponent of power and establishment. Here is the emergence of the great man as the embodiment of the great idea, which is so significant in the twentieth century. The Duce and the Führer were not just heads of state; they were embodiments of a great idea and of the state. Mussolini uses Hus to develop what will become one of the most influential and damaging political philosophies of the twentieth century.

15 Cf. Paul P. Bernard and Bentley B. Gilbert, "Mussolini on Huss: Notes on the Birth of a Fascist," Colorado College Studies 1 (1958): 25-28. 


\section{The Book's Afterlife}

Parts of the book were reprinted in January 1918 in the post-socialist newspaper Mussolini founded as he was developing fascism, Il Popolo d'Italia (The People of Italy). It was probably part of his support for Czechoslovak efforts in the war at that time, stoking anti-German sentiment. When Mussolini assumed power on October 28, 1922, after the famous march on Rome, the book's fortunes declined rapidly. One reason is obvious: antiestablishment revolutionism is fine when you are not the establishment. Mussolini quickly became the establishment after 1922, and a once-helpful ideology was not so helpful anymore. Secondly, Mussolini needed to stabilize church-state relations. In the Vatican City there is a straight road between the Vatican and the centers of power in Rome, built by Mussolini to symbolize the 1929 Lateran Pact, which granted Vatican City independence and (in contradiction to everything Mussolini writes in this book) to recognize Catholicism as Italy's state religion, granting significant benefits, powers, and favors to the Church which continue to be a problem in Italian politics today. So Mussolini withdrew his book from circulation and even from libraries, although his pride in the work was evident from the fact that he continued to reference it and have it referenced in other works over which he had editorial control. He remained proud of it, even if he felt it necessary to censor his own work.

\section{Conclusion}

Hus, the fifteenth-century heretic, plays a significant part in the development of European politics in the twentieth century because of the way he was appropriated by Mussolini at a critical point when he was about to break with the Socialist Party and found his own Popular Front Movement, which became the Italian fascist party.

A second translation of this book was published in 1939 in America. ${ }^{16}$ It was sponsored by the superficially friendly but ominously named Italian Book Company of New York. In the introduction we see the rationale of the translator and the publisher for this edition:

We publish [this book] as a reverent homage to the Duce, to bring out the figure of a great writer who remains in the shadow of the statesman. We will know that the

${ }^{16}$ Ed. note: the book was already translated and published in New York in 1929; however, the 1939 translation is new and added an English preface. See Helan, "Mussolini Looks at Jan Hus," 316. 
Duce, in his modesty, does not like to speak of his past struggle and glory and seems to wish to ignore his early work as a writer and polemist. The past hardly interests him now as a positive man looks only to the future with a serene eye. To a friend who tells him to have religiously preserved some of his letters he answers: "The past is not an end to itself, but a period of transition of an unlimited line which is called progress. To stop means to fall back. We must go on, in order to improve and uplift ourselves evermore."17

${ }^{17}$ Mussolini, fohn Huss, 6. 


\title{
Bound, Freed, Freed to Be Bound: The Wittenberg Understanding of Justification
}

\section{ROBERT KOLB}

\begin{abstract}
This essay focuses on the Wittenberg teaching on justification directly following the presentation of the Augsburg Confession in 1530. Martin Luther's understanding of justification was based on Christ's atoning work in dying to eradicate sin and guilt and in rising to restore righteousness to his people. The benefits of Christ are given through the pronouncement of forgiveness by the effective word of absolution in all forms, and appropriated through trust in the promise of Christ. Despite scholarly attempts to drive a wedge between him and his Wittenberg colleague, Philip Melanchthon shared Luther's view, though they expressed some elements differently. Both agreed that those who receive righteousness, a new identity as God's child passively, will actively practice God-designed righteousness toward others.
\end{abstract}

\section{Historical Context}

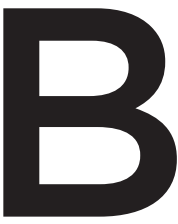

y 1531 Wittenberg theology had taken on its fundamental shape. The maturing thought of its leaders, Martin Luther and Philip Melanchthon, had had thirteen years in which to test the agenda for reform which they had developed in the heat of controversy, as it unfolded after Luther posted his Ninety-Five 
Theses on indulgences in late 1517. Very seldom did he comment further on that topic, which, while symptomatic of his deep pastoral concern for the consolation of believers, only implicitly addressed the heart of what he was discovering in his biblical lectures. His Ninety-Five Theses generated fear that he was undercutting papal authority among its defenders, and their attacks focused attention on issues of ecclesiology. Luther pursued a different path, for his biblical studies had led him to define the Christian faith in a different way than had his predecessors. The "article [on which] stands all that we teach and practice against the pope, the devil, and the world," from which "nothing ... can be conceded or given up, even if heaven and earth or whatever is transitory passed away," to use his words in his Smalcald Articles of 1537, had become the teaching "that pertain[s] to the office and work of Jesus Christ, or to our redemption, ... that Jesus Christ, our God and Lord, 'was handed over to death for our trespasses and was raised for our justification' (Rom. 4[:25]); and he alone is 'the Lamb of God, who takes away the sin of the world' (John 1[:29]); and 'the Lord has laid upon him the iniquity of us all' (Isa. 53[:6])."1

The faith fostered by Luther's forebears at home, university, and monastery reflected ancient, pre-Christian rhythms that had been incorporated into the new religion when newly converted princes converted their subjects en masse as the faith spread into the lands north of the Mediterranean world. Biblical figures and concepts mixed with the pagan structures as the faith took form in Germanic and Slavic villages across northern Europe. Ritual approaches by human beings sustained the relationship between them and God, and they looked to priests within a hierarchical sacred structure for assurance that the religious activities they were performing actually would obtain the needed help and favor they sought through their performance. Instead, Luther discovered a different understanding of being Christian as his strongly emotional character read Holy Scripture through lenses ground by instructors in the Ockhamist tradition. Luther rejected their understanding of the necessity of human merit to earn the grace necessary to perform truly good works. But their insistence on the absolute, unconditioned power (potentia absoluta) of God formed his perception of the Creator as the almighty re-creator of sinners, as he acts through the message of the forgiveness of sins on the basis of Christ's death and resurrection.

1 Die Bekenntnisschriften der Evangelische-Lutherischen Kirche, ed. Irene Dingel (Göttingen: Vandenhoeck \& Ruprecht, 2014) [henceforth BSELK], 726-29; The Book of Concord, ed. Robert Kolb and Timothy J. Wengert (Minneapolis: Fortress, 2000) [henceforth BC], 300-301. 
Luther was assimilating a series of new insights into what God was saying to him in Scripture as Philip Melanchthon accepted the position of professor of Greek at the University of Wittenberg in 1518. The two of them shared insights and ideas; by 1520/1521 the framework of Wittenberg theology had reached a form that it would retain through the lifetimes of these two despite continuing experiments in how to address new questions in the rapidly changing context of their time. ${ }^{2}$ Luther formulated his understanding of God's bestowal of righteousness on sinners through Christ's death and resurrection and through the gift of trust in him in his treatise On the Freedom of a Christian (Latin: De Libertate Christiana) in 1520. What God's justifying action means for believers he summarized in two theses: "A Christian is a free lord over all things and subject to no one. A Christian is a submissive servant, subject to all," claiming that he was only repeating what Paul had said in 1 Corinthians 9:19. ${ }^{3}$ Christians, he elaborated, are liberated from all their spiritual foes: Satan, sin, death, hell, the accusation of the law, and God's wrath. He aimed to console the conscience. The comfort of the gospel frees sinners from striving to secure their own lives, and so he argued that this person is now free to exercise humanity as God designed it, in service to others.

By 1531 the Wittenberg theologians had been subjected to the political test of explaining their positions before Charles V, the emperor of the German lands. Melanchthon drafted the justification of the introduction of Wittenberg-encouraged reforms for the emperor at the diet of the German empire in Augsburg in 1530. At first, he intended to call this explanation a defense, an "apologia," but he changed its title to "confession" when he decided that it was necessary to set forth the fundamentals of Wittenberg teaching. The emperor commissioned a group of theologians faithful to the papacy to draft a confutation, and Charles accepted their arguments and commanded the followers of Luther to return to papal obedience by April 15, 1531. The Confutation of the Augsburg Confession found many points of agreement with Melanchthon's statement of the faith, but on many topics took exception to Luther's departure from medieval teaching. It acknowl-

2 On the much-disputed question of whether Melanchthon abandoned and undercut Luther's understanding of justification, see the answer to the nineteenth-century liberal and twentieth-century "Luther Renaissance" charge in Rainer Flogaus, "Luther versus Melanchthon? Zur Frage der Einheit der Wittenberger Reformation in der Rechtfertigungslehre," Archiv für Reformationsgeschichte 91 (2000): 6-46. Flogaus demonstrates their essential agreement even when they differ in expression.

3 D. Martin Luthers Werke (Weimar: Böhlau, 1883-1993 [henceforth WA]), 7:21, 1-6; Luther's Works (Saint Louis: Concordia; Philadelphia: Fortress, 1958-1986 [henceforth LW]), $31: 344$. 
edged that faith plays a role in the justification of sinners but nonetheless insisted on the role of human good works in sustaining the relationship between God and his human creatures. "To reject human merit, which is acquired through the assistance of divine grace, is to agree with the Manicheans and not the catholic church." 4 Two different understandings of the Creator's relationship to human creatures, two different interpretations of what it means to be human, and differing definitions of key biblical conceptsincluding "grace," "faith," and "Christ's merits" —had created a serious gap between the two sides in Augsburg. This demanded extensive explanation from the Wittenberg theologians, which they undertook in the course of the early 1530 s in lectures and publications.

In the tense political situation, with the threat of military action hanging over the heads of all those committed to Luther's reform, the Wittenberg theologians struck back with what had become their most powerful weapon, God's Word. Melanchthon drafted his Apology of the Augsburg Confession, publishing his initial version in April 1930 and a revised rendition in September. Christian Peters has demonstrated the vital role which Luther played in this revision. ${ }^{5}$ From July 3 to December 12 Luther lectured on Galatians. The next year Melanchthon lectured on Romans. Both Melanchthon's treatment of the justification of sinners through faith in Christ in the Apology and his Romans lectures and Luther's discussions of the same topic in the Galatians lectures contain classical expressions of the Wittenberg understanding of how God has rescued sinners from their sin and its consequences and how he restores their relationship to himself through his Word.

\section{Christ's Atoning Work}

The Wittenberg understanding of justification was anchored in Luther's and Melanchthon's understanding of Christ's atoning work. They did not sharply distinguish the Holy Spirit's creating and nurturing saving trust in God from the deeds and activities of Jesus Christ, as delivered by the Holy Spirit through the Word from the cross and empty tomb that they believed formed the basis of the Spirit's saving activity. Because their contemporary opponents took for granted that salvation rested in one fashion or another (depending on the specific approach of individual scholastic and monastic

4 Die Confutatio der Confessio Augustana vom 3. August 1530, ed. Herbert Immenkötter (Münster: Aschendorff, 1979), 85-86; ET, Sources and Contexts of the Book of Concord, ed. Robert Kolb and James A. Nestingen (Minneapolis: Fortress, 2001), 108-9.

5 Christian Peters, Apologia Confessionis Augustanae: Untersuchungen zur Textgeschichte einer Lutherischen Bekenntnisschrift, 1530-1584 (Stuttgart: Calwer, 1997), 421-60. 
theologians) on Christ's incarnation, death, and resurrection, they paid less attention to their specific formulation of their teaching on the atonement, concentrating the focus of their proclamation of salvation on the role of trust in salvation.

\section{Christus Victor and Joyous Exchange}

Nearly a century ago the Swedish theologian of the Lundensian school Gustaf Aulén opened a discussion of doctrines of the atonement that focused at least partially on Luther; his method sought to identify the primary motifs in Christian thought. He argued that among medieval and modern theologians Luther stands alone in holding primarily to the ancient church's emphasis on atonement through "Christus Victor"; the relationship between sinners and their Judge is restored through Christ's victory over the sinners' enemies: the sinner, sin, death, and Satan. Aulén conceded that Luther had occasionally spoken in terms of the medieval doctrine of the atonement through vicarious satisfaction of God's legal claims on the human being, but he dismissed such references as falling outside Luther's fundamental orientation. ${ }^{6}$ Ian Siggins provides a healthy corrective to Aulén, arguing that Luther has no "coherent explanatory discourse about how the atonement works," but instead his sermons and lectures "abound in the motifs which figure in the historic atonement theories-patristic, classic, dramatic, or Western, Latin, and penal; objective or subjective."7 Luther indeed spoke of the Savior's assuming the sins of the world, tying together Romans 4:25, "Christ was handed over to death for our trespasses and was raised for our justification," and the delivery of the blessings of his substitutionary death and resurrection in baptism (Rom 6:3),

Do you not know that all of us who have been baptized into Christ Jesus were baptized into his death? Therefore, we have been buried with him by baptism into death, so that, just as Christ was raised from the dead by the glory of the Father, so we too might walk in newness of life. ${ }^{8}$

Early in his career Luther had appropriated the image of the bride and bridegroom and their "joyous exchange" (fröhlicher Wechsel) from the

6 Gustaf Aulén, Christus Victor: An Historical Study of the Three Main Types of the Idea of Atonement, trans. A. G. Herbert (New York: Macmillan, 1961). What follows is derived from Robert Kolb, "Das Kreuz-die wirkliche Befreiungstheologie," Confessio Augustana 4 (2016): 43-54.

7 Ian D. K. Siggins, Martin Luther's Doctrine of Christ (New Haven:Yale University Press, 1970), 109.

8 Robert Kolb, "Resurrection and Justification: Luther's Use of Romans 4, 25," Lutherjahrbuch 78 (2011): 39-60. 
monastic-mystical tradition in which the Augustinian Eremite order had immersed him. For example, his On the Freedom of the Christian had compared what Christ does for sinners with the property arrangements made under Germanic common law for a married couple, that is, the complete sharing of ownership. This model did not provide the perfect depiction of Christ's gift of forgiveness and the eradication of guilt, but Luther used it to proclaim that Christ had taken full possession of the sinner's sin and guilt while sinners now possessed their sins no more but possessed only the righteousness and innocence of the bridegroom Jesus. ${ }^{9}$ It must be noted that this form of union with Christ, in contrast to strands of mysticism that posit the loss of materiality and identity of the individual who is taken into the divine, is a union in which the individuality of the two partners is heightened and, in the case of the bride, perfected-once again, through this union.

In his lecture on Galatians 3:13 in 1531, Luther adopted another expression of the "joyous exchange": Christ takes on the criminality of the sinner before the judge, and sinners receive Christ's innocence in the judge's perception. The prophets [Luther was probably thinking above all of Isaiah $\left.53^{10}\right]$ had foreseen

that Christ was to become the greatest thief, murderer, adulterer, robber, desecrator, blasphemer, etc., there has ever been anywhere in the world. As such, he is not acting in his own person. In this case, he is not God's Son, born of the Virgin. He is instead a sinner, who has and bears the sin of Paul, the former blasphemer, persecutor, and mugger; of Peter, who denied Christ; of David, the adulterer and murderer, who caused the Gentiles to blaspheme the name of the Lord. To summarize he is the one who possesses and bears all the sins of every person in his body. ${ }^{11}$

Luther repeated this thought in a dialogue constructed between Jesus and God the Father, in which God tells him,

you are Peter, the denier; Paul, the persecutor and blasphemer, the man of violence; David, the adulterer; that sinner who ate the apple in Paradise; the thief on the cross. To summarize, you are the person of all people, the one who commits the sins of all people. Therefore, see to it that you pay and make satisfaction for them. ${ }^{12}$

9 WA 7:25, 26-26, 12; LW 31:351.

${ }^{10}$ See his lectures on this chapter from 1529, WA 31, 2:428, 5-441, 11; LW 17:215-32, and from 1544, WA 40, 3:685-746.

11 WA 40, 1:433, 26-32; LW 26:277; Luther labeled this the "joyous exchange," WA 40, 1:443, 23-24; LW 26:284.

12 WA 40, 1:437, 23-27; LW 26:280. 
There can be no doubt that Luther taught that Christ's crucifixion as the substitute for sinners satisfies the law's demand for the sinner's death.

Thirteen years later Luther regarded the concept of "satisfaction" as too weak to express what had taken place in Christ's atoning work, since it gives insufficient honor to Christ's suffering; for "he not only made satisfaction for $\sin$, but he loosed the chains that held us under the power of death, the devil, and hell. He secured for us the eternal kingdom of grace and the daily forgiveness of all sins that are in us."13 Christ's payment for sin was not a fine- - he used Peter's words (1 Pet 1:18) in his Small Catechism (1529)—as could be paid with gold or silver, but it was rather a sacrifice. ${ }^{14}$ In 1531 he told his students, using one of his favorite Bible passages, John 1:29, that the Lamb of God, though without spot or blemish, bears the sins of the world:

Christ was not just found among sinners, but he freely, according to his Father's will, desired to be the comrade of sinners, assuming the flesh and blood of those who are sinners, thieves, those immersed in sins of all kinds. Therefore, the law found him among thieves with the result that it condemned and executed him as a thief. ${ }^{15}$

Through this imagery Luther had repeated the theme that had given his only larger work on the justification of Christ's people, On the Freedom of a Christian, its structure and title. Christ rose from the dead and left the grave to give his chosen people freedom to be truly human again and enjoy the Edenic relationship with their Creator. Aulén's "Christus Victor" theme is certainly present and prominent in Luther's writings, as his Galatians commentary reveals. Luther writes in his comments on Galatians 1:1 that Christ's

victory is a victory over the Law, sin, our flesh, the world, the devil, death, hell, and all evils; and this victory of his he has given to us. Even though these tyrants, our enemies, accuse us and terrify us, they cannot drive us into despair or condemn us. For Christ, whom God the Father raised from the dead, is Victor over them, and he is our righteousness. ${ }^{16}$

He informed his students that Paul was telling them that "I could be liberated by nothing else than Christ's death and blood from sin, death, and the curse upon me. Therefore, I conclude with full certainty and assurance that it was necessary for Christ to conquer sin, death, and the curse upon me"

\footnotetext{
13 WA 21:264, 21-35.

14 BC 353.

15 WA 40, 1:434, 16-20; LW 26:278.

16 WA 40, 1:65, 12-17; LW 26:21-22; Uwe Rieske-Braun, Duellum mirabile: Studien zum Kampfmotiv in Martin Luthers Theologie (Göttingen:Vandenhoeck \& Ruprecht, 1999), 66-100.
} 
since his own works could not accomplish this liberation. ${ }^{17}$

Luther labeled the confrontation of Satan and Christ a "magnificent duel." In that one-on-one battle,

Christ abolishes the law, kills my sin, destroys my death in his body, and empties hell thereby; he judges the devil and crucifies and casts him down into hell.... Everything that once tormented and oppressed me Christ has gotten rid of. $\mathrm{He}$ disarmed it all and put it on public display. He triumphed over these things so that they cannot lord it over me but are compelled to serve me. ${ }^{18}$

His conquering of all the enemies of the sinner liberates his people and transfers them from Satan's realm to Christ's.

Living in me, Christ destroys the law, damns my sin, murders my death, because they are not able to not vanish in his presence. Christ is my eternal peace, consolation, righteousness and life. Therefore, the terror of the law, melancholy of the soul, sin, hell, and death cannot do anything else but give way to him." ${ }^{19}$

Christ's resurrection liberates from the accusation of the law and guilt. Christ took upon his shoulders all human sin, the law's accusation, death, the devil, and hell, and in his death he has slain them..$^{20}$ The most powerful, most cruel tyrant, sin, which exercises dominion and governance over the whole world, stands over against eternal, immoral, invincible righteousness.

It assaults Christ and wants to gobble him down along with all other human beings. But sin did not perceive that this person is invincible and eternal righteousness. Thus, in this duel it was inevitable that sin be conquered and killed and that righteousness conquer and live. Thus, in Christ all sin is conquered, executed, and buried. Righteousness remains the victor and the ruler forever. ${ }^{21}$

Christ now terrorizes the devil: with his victory over sin, death, and Satan, he has destroyed his rule, and continues to preserve and protect his people against the gates of hell itself (Matt 16:18). ${ }^{22}$ Luther used the victory motif in Ephesians 2:14-15 and Psalm 68:18 to demonstrate that

with his victory Christ has made the law flee from our consciences so that it cannot take away our confidence in God's presence anymore, and drive us to despair as it

\footnotetext{
17 WA 40, 1:458, 22-27; LW 26:295.

18 WA 40, 1:274, 24-34; LW 26:160-61.

19 WA 40, 1:283, 34-284, 14; LW 26:167.

${ }^{20}$ WA 40, 1:272, 19-273, 32; LW 26:159-60.

21 WA 40, 1:439, 17-27; LW 26:281; cf. on Christ's duel with the accusation of the law, WA 40, 1:564, 26-367, 12; LW 26:369-71. Cf. Rieske-Braun, Duellum, esp. 89-100.

22 WA 40, 1:356, 31-34; LW 26:224.
} 
condemns us. It does not cease showing us our sin, accusing and frightening us, but the conscience takes hold of the apostle's words, "Christ has redeemed us from the law" and is set up straight by faith and takes hold of his consolation. ${ }^{23}$

Christ came into the world to bestow grace and peace, the words Paul used from the common greetings of his day to express God's greatest gifts. $\mathrm{He}$ does so by "condemn[ing] sin, destroy[ing] death, and stomp[ing] the devil underfoot."."

Christ's victory over Satan secured his reclamation as his own of the people who had belonged to God's family and had strayed from their home with him. In his Small Catechism Luther explained that Christ had "redeemed me, a lost and condemned creature, acquired possession of me and won me from sin, death, and the devil." He had done this "that I might belong to him, live under him as he reigns, and serve him in everlasting righteousness, blessedness, and innocence." ${ }^{25}$ Two years later he commented on Galatians 4:7 that Christ's liberation of sinners from their slavery to Satan had given them "nothing but freedom, adoption, and sonship." ${ }^{26}$ This status, closely linked with Christ's setting sinners free from all that held them as slaves, means that Christ's people enjoy through faith all the blessings that God's acting as their father provides as they accept him as such through faith. ${ }^{27}$

\section{Re-creation and New Birth}

The realization of this new life that has experienced justification in God's sight comes through Christ's act of re-creation. Luther's belief that God's Word fashioned all reality in the beginning provided the background for his description of the application of Christ's atoning work throughout the history of the church through the pronouncement of the forgiveness of sins. Luther's Ockhamist background bequeathed him his conviction that God accomplishes his saving will through selected elements of his created order-above all the human language that announces and pronounces forgiveness of sins and bestows life and salvation with this forgiveness. His concept of God's Word as the actual power of God for salvation provided great comfort for those who experienced the Holy Spirit's dynamic action in this act of re-creation and renewal of righteousness in God's sight. Luther demonstrated Christ's divinity through the fact that he creates "grace, peace, eternal life, the forgiveness of sins, justification, life, and deliverance from

\footnotetext{
${ }^{23}$ WA 40, 1:566, 21-28; LW 26:371.

${ }^{24}$ WA $40,1: 82,26-27$; LW 26:32.

${ }^{25}$ BSELK, 872; BC, 355.

${ }^{26}$ WA 40, 1:593, 9; LW 26:389.

${ }^{27}$ WA 40, 1:593, 15-600, 20; LW 26:389-94.
} 
death and the devil — works not of any creature but of the divine majesty." 28

The theme of "new creation" or "new birth" formed Luther's perception of the essential identity of those who trust in Christ and of their capacity to live out the righteousness Christ has freely bestowed on them in daily life through the power of the Holy Spirit. When the law's accusation has reduced sinners to nothing, God acts: "He is the almighty Creator who makes everything out of nothing." 29 God's justifying action is thus forensic, the action of words that create reality because they come from the one who creates by speaking. What God says does not describe what is already there; instead, God speaks reality into existence. As in the beginning of creation, God fashions from the nothingness of sin new children of God and does so through his Word. ${ }^{30}$ Luther described God's Word that conveys the forgiveness of sins as a "womb":

God's Word is the divine womb in which I was born. It is the birth through which I came into existence. He created me and made me his child. We are his heirs and have the forgiveness of sins. We are safe in confronting the devil because salvation has been given us because we have been created as new creatures. ${ }^{31}$

Obedience to the law could not revive the sinner; it could not serve as a path to a different life. "The law cannot produce a new nature, a new birth. It places before our eyes our old birth by which we were born under the rule of the devil. It prepares us for the new birth which comes to be through faith in Christ Jesus." ${ }^{32}$ This new birth does not take place, Luther told his students, through imitating Christ. (Luther associated the imitation of Christ with the late medieval model which saw copying Christ's way of life, particularly celibacy and poverty, as the most efficient way to gain merit in God's sight.) Rather, this new birth is a new creation. In Paul's words in Galatians 3:27, it is putting on Christ and taking off the leather tunic of Adam, "a deadly tunic and a garment of sin," worn by those "who were subject to and sold into slavery under sin, horrible blindness, ignorance, contempt for and hatred of God in us." 33

${ }^{28}$ WA 40, 1:80, 25-81, 13; LW 26:31.

${ }^{29}$ WA 40, 1:488, 19; LW 26:314.

${ }^{30}$ On the discussion of Tuomo Mannermaa's rejection of Luther's understanding of justification as non-forensic, see Risto Saarinen, "Justification by Faith:The View of the Mannermaa School," in The Oxford Handbook of Martin Luther's Theology, ed. Robert Kolb, Irene Dingel, and Lubomir Batka (Oxford: Oxford University Press, 2014), 254-63, and Mark Mattes, "Luther on Justification as Forensic and Effective," in ibid., 264-73.

${ }^{31}$ WA 40, 1:597, 6-7 (in student notes on the lecture on Galatians 4:7, but not in the printed commentary of 1535). This imagery occurs often in Luther's preaching and teaching, e.g., WA 5:505, 29-34; WA 10, 1, 1:232, 12-15.

32 WA 40, 1:539, 13-16; LW 26:351.

${ }^{33}$ WA 40, 1:540, 17-22; LW 26:352. 
It is in the context of this conviction that the restoration of human identity as God's child takes place through the re-creative Word of God that Luther's appropriation of the terms imputare and reputare are to be understood. Relatively seldom used in medieval theology, ${ }^{34}$ they express the Wittenberg reformers' conviction that when God regards his chosen as righteous, or pronounces them righteous, he is not merely observing or describing reality but rather creating it. When God says "forgiven," sin vanishes from his sight, where the ultimate reality rests. Luther despaired over the mystery of the continuation of sin and evil in human life, ${ }^{35}$ especially in the lives of God's faithful people, and he perceived that God's chosen remain in the struggle against the permeating sinfulness that makes daily repentance necessary. But their fundamental, essential identity once God has spoken them free from sin is that of a child of God.

Luther favored the image of new birth because the passive nature of the gift of life and identity through birth made clear that God's re-creating love sets no conditions and has no basis in the sinner. Paul's reference to believers' becoming heirs of Christ in Galatians 4:7 gave the professor the opportunity to make this clear:

For by being born a person earns the status of heir. No work, no merit appropriates the inheritance, but birth alone. An inheritance falls to a person in a totally passive manner, not in an active way. That is, being born, not producing or laboring or worrying, etc., make a person an heir. For a person does nothing in order to be born; it simply happens to a person. Therefore, we gain these eternal blessings passively, not actively. They include remission of sins, righteousness, the glory of the resurrection and life eternal. ... Thus, only faith fashions children of God, born from the Word, the divine womb, in which we are conceived, gestate, are born, raised, etc. ${ }^{36}$

Thus, Luther labeled this distinction between the passive righteousness that God unconditionally bestows in relationship with himself upon his chosen people and the active righteousness they then display in the performance of God's commands because they have been born anew. In sketching the argumentum or basic message of Galatians in the preface to the published commentary of 1535 Luther labeled this distinction of the two aspects of God-given righteousness "our theology." ${ }^{37}$

\footnotetext{
${ }^{34}$ Johannes Altensteig, Vocabularius Theologie complectens vocabulorum descriptiones ... (Hagenau: Johannes Rynmann, 1517), CXIIa and CCXVIIIb, where the terms should occur.

${ }^{35}$ WA 18:719, 9-12; LW 33:190.

36 WA 40, 1:597, 15-25; LW 26:392.

37 WA 40, 1:45, 24; LW 26:7; cf. Robert Kolb, "Luther's Hermeneutics of Distinctions: Law and Gospel, Two Kinds of Righteousness, Two Realms, Freedom and Bondage," in Oxford Handbook, 176-78, and Robert Kolb, "Luther on the Two Kinds of Righteousness: Reflections
} 
Luther believed that righteousness bestows the identity of child of God on sinners as it comes through God's Word of absolution, whether encountered in oral, written, or sacramental form, and the Wittenberg theologians conceived of this word as a promise. Promises elicit trust from those to whom they are given. As Luther struggled in the 1510s with his doubts and despair over his own sinful identity, his unrighteousness, he came slowly to the conclusion that God's Word alone, which delivers what Christ had won for him in his death and resurrection, can change the reality of the sinner's life. That change comes through the promise that God will be faithful in viewing that sinner as righteous.

\section{Faith}

Luther defined faith as a gift of God that establishes the relationship between the faithful Creator and Savior and the forgiven sinner. Melanchthon aided him in understanding that Paul's concept of pistis ( $\pi$ i $\sigma \tau / \varsigma)$ was better translated with the Latin fiducia or the German Vertrauen than with fides, which medieval theologians viewed as mere acknowledgement of facts, "historical faith," and Glaube. (Nonetheless, both Wittenberg professors continued to use Glaube for the faith that not only recognizes the factuality of Christ's death and resurrection and assents to the "for me" character of God's promise to deliver the effects of Christ's work to the believer, but also actually trusts totally in the promise.) This faith recognizes and shares God's regard for the believer and joyfully accepts being his child; it found early expression in Luther's use of the bride and bridegroom image of the relationship between Christ and believers. They trust in him who has loved them through death and resurrection. Trust in his promise produces trust in his person, which opens trust in the possibility of performing his will. Although Luther and Melanchthon increasingly distinguished God's act of restoring human righteousness in his sight from the result of that restoration in his people's obedience to his plan for human living, they viewed the two aspects of human righteousness as inseparable, two sides of the same identity. Those who experience new birth through the Holy Spirit's delivery of the promise in oral, written, or sacramental forms of God's Word are righteous, passively in relationship to God and actively in their response to him in prayer and praise and in service and love displayed toward other human beings.

on His Two-Dimensional Definition of Humanity at the Heart of His Theology," Lutheran Quarterly 13 (1999): 449-66. 
As Erik Erikson's modern psychological theory has highlighted, ${ }^{38}$ trust is foundational to the human personality. As Luther wrote in his explanation of the first commandment in the Large Catechism, human trust creates its gods. Only trust in the true God, who has revealed himself in Jesus Christ, can restore human identity to its original, God-created form. ${ }^{39}$ This trust brings God into clear focus, according to Luther. With his reference to God's reckoning Abraham's faith as righteousness, Paul had made faith in God "the highest worship, the highest veneration, the highest obedience and sacrifice" to the Creator: faith "places Godness in the highest place ... it creates God's being God, not in his substance, but in us. Apart from faith, God loses his glory, wisdom, righteousness, truth, [and] mercy" for human beings. ${ }^{40}$ "Faith restores righteousness because it gives God what is his due." "Faith is nothing other than having the truth in the heart, that is, the proper recognition of God in the heart," a recognition that human reason cannot construct and is not accessible apart from God's Word. ${ }^{42}$ Faith also identifies the believer as God's forgiven child.

Luther formulated his exclusive focus on faith as that which constitutes righteousness in the believer in opposition to the Roman Catholic insistence that human merit plays a significant, even decisive, role in making sinners righteous in God's sight.

It is praiseworthy and blessed to imitate the example of what Christ did-love the neighbor, to do good to those who have earned evil, to pray for enemies, to patiently bear the ingratitude of those who repay good with evil. But none of this bestows righteousness in God's sight.

Like Abraham, believers rely only on faith, for it is regarded by God as righteousness. ${ }^{43}$

The mystery of the continuation of sin and evil in the lives of those who have received God's promise commanded Luther's attention often. He told his students that it is sometimes hard to perceive external signs that faith is present, such as enjoying hearing the Word, confessing Christ, even at personal cost, not delighting in sin, serving in one's own calling and not interfering with others in their callings. Such confirmation may or may not

${ }^{38}$ Erik Erikson, Child and Society (New York: Norton, 1950); Insight and Responsibility (New York: Norton, 1964), esp. 81-107; Identity, Youth and Crisis (New York: Norton, 1968), esp. 91-141.

${ }^{39}$ BSELK 930/931-936/937; BC 386-88.

${ }^{40}$ WA 40, 1:360, 17-35; LW 26:226.

${ }^{41}$ WA 40, 1:361, 12; LW 26:227.

${ }^{42}$ WA 40, 1:376, 23-28; LW 26:238.

43 WA 40, 1:389-90; LW 26:247-48. 
be present or powerful enough to combat doubt and despair. Therefore, believers must repeat to themselves that God is faithful in his favor for his own. Struggling against doubt, believers should say with confidence,

I know that God has accepted me, that I have the Holy Spirit, not because of my own worthiness or virtues, but for Christ's sake, who for our sake submitted himself to the law and bore the sins of the world. I believe in him. If I am a sinner and I stray, he is righteous and cannot depart [from his faithfulness].

With that faith believers break forth in praise for God and love for the neighbor. ${ }^{44}$

\section{Melanchthon}

Melanchthon's way of expressing this teaching differed from Luther's at times, but throughout their more than twenty-five years as colleagues they shared the same essential view of the justification of sinners through faith in Christ alone. "All of Christian teaching revolves around that topic of how we become righteous in God's sight. This definition is the chief part and summary of all Christian teaching," he wrote in $1529 .{ }^{45}$ Melanchthon spoke of "excluding particles" (particula exclusiva), such as "by grace" or "by faith alone" "or apart from the merit of the law" as vital for the proper understanding of God's justifying action through faith in Christ. These phrases exclude any possibility of human merit playing a role in the salvation of sinners, he argued in direct opposition to the Roman Catholics with whom he had negotiated in Augsburg. ${ }^{46}$

Melanchthon's description of Christ's atoning work tended to emphasize his vicarious satisfaction of the law's demand for the death of the sinner more than Luther's did. In his Apology of the Augsburg Confession, he wrote against his Roman Catholic opponents, "The wrath of God cannot be conciliated as long as we set our own works against it because Christ has been set forth as the propitiator in order that on his account the Father may be reconciled with us." ${ }^{17}$ Melanchthon often attempted to express his contrary views in the language of his critics; he described this propitiation in terms of satisfaction and debt: the propitiator's

\footnotetext{
${ }^{44}$ WA 40, 1:578, 28-31; LW 26:379.

${ }^{45}$ Corpus Reformatorum: Philippi Melanchthonis Opera quae supersunt omnia [henceforth CR], ed. Karl G. Bretschneider (Halle: Schwetschke, 1848), 15:445.

${ }^{46}$ CR 15:503-4; Philip Melanchthon, Commentary on Romans, trans. Fred Kramer (St. Louis: Concordia, 1992), 18.

${ }^{47}$ Apology IV, BSELK 301; BC 133.
} 
merits must be authorized to make satisfaction for others who are given these merits by divine reckoning in order that through them, just as though they were his own merits, they may be reckoned righteous. It is as when a person pays a debt for friends, the debtors are freed by the merit of the other, ... Thus, Christ's merits are given to us so that we might be reckoned righteous by our trust in the merits of Christ when we believe in him, as though we had merits of our own. ${ }^{48}$

But Melanchthon also described justification as a liberation from the accusation of the law, from sin and death, a liberation that brings righteousness and joy to believers. ${ }^{49} \mathrm{Christ}$ is not only the one who sacrificed himself for sinners but also their liberator and savior. ${ }^{50}$

Melanchthon's emphasis on God's Word as the decisive factor in creating the new person in Christ relied, as Luther's did, on the biblical view of that Word as creative, in bringing all creation into existence in the beginning, and continuing as his re-creative Word of absolution in the rescue and restoration of sinners. His 1532 commentary on Romans defined conversio, conversion, or regeneratio, new birth, with three elements: God's forgiving the sinner, God's restoring righteousness or the reckoning of righteousness to the sinner, and the gift of the Holy Spirit as the source of the fruits of faith, and eternal life. ${ }^{51}$ That this was an action that God carried out through his Word was clear for Melanchthon on the basis of Hebrew usage, Paul's expressions, and the use of the concept of "justification" in the ancient Roman world, using the "justification" of Romanus Scipio as an example.

It is therefore by faith that we are justified, in that we are regarded [reputamur] as righteous by God for Christ's sake when we believe. The word "righteousness" does not signify the righteousness of the law or obedience in general, or any of our qualities, for it says, "by faith righteousness is given to us," and that signifies the imputation of righteousness or our acceptance [by God]. This is to be understood in terms of relationship, as acceptance to eternal life. But it is necessary to recognize that with the remission of sins the Holy Spirit is given at the same time ... we are set straight through faith. Thus, the gift of the Holy Spirit is connected to justification, and he does not give just one virtue, faith, but initiates the others: fear and love of God, love of the truth, chastity, patience, the practice of justice toward the neighbor. ... These virtues do not merit remission of sins, nor is a person accepted as righteousness because of them. ${ }^{52}$

${ }^{48}$ Apology XXI, BSELK 567; BC 240.

${ }^{49}$ CR 15:507-8; Melanchthon, Commentary on Romans, 22.

${ }^{50}$ CR 15:509; Melanchthon, Commentary on Romans, 24.

${ }^{51}$ CR 15:506; Melanchthon, Commentary on Romans, 21.

${ }^{52}$ CR 15:510-11; Melanchthon, Commentary on Romans, 25. 
Melanchthon held as clearly as Luther that God justified sinners in a forensic manner, that is, through his word of absolution that created a new person who trusted Christ. Through Christ, the Lamb of God, who takes away the sins of the world,

remission of sins and the imputation of righteousness are certainly given to us, not because of any works or merit of our own but by grace and by faith, when we believe that these things are truly for us and have certainly been given us for Christ's sake. When we are set straight by this faith and continue to fix our gaze on Christ, we truly receive remission of sins and are regarded as righteous, that is accepted in the presence of God, and we are given the Holy Spirit, and we are made children of God, heirs of eternal life (John 1:12-13)..$^{53}$

The forensic activity of Christ involved more for Melanchthon than his absolution from sin and guilt. Christ's activity as advocate and mediator before the Father's throne day in and day out assured sinners that the one who had sacrificed himself for them continued to intervene in their behalf. ${ }^{54}$

Melanchthon's understanding of faith as the constitutive factor in human righteousness in believers formed his defense of the Augsburg Confession's teaching that

we cannot obtain forgiveness of sin and righteousness before God through our merit, work, or satisfactions, but ... we receive forgiveness of sin and become righteous before God out of grace for Christ's sake through faith when we believe that Christ has suffered for us and that for his sake our sin is forgiven and righteousness and eternal life are given to us. (IV) ${ }^{55}$

In the Apology of the Augsburg Confession (IV) he wrote that "the faith that justifies is not only a knowledge of history; it is to assent to the promise of God, in which forgiveness of sins and justification are bestowed freely on account of faith.... To have faith is to desire and to receive the offered promise of the forgiveness of sins and justification." ${ }^{56}$ This kind of faith "is not an idle thought but one which frees us from death, produces new life in our hearts, and is a work of the Holy Spirit; it does not exist with mortal sin. Instead, as long as it is present, it brings forth good fruit." ${ }^{57}$ Personal faith trusts that sins "are remitted on account of Christ and that God is reconciled

${ }^{53}$ CR 15:501; Melanchthon, Commentary on Romans, 16; cf. CR 15:510-11; Melanchthon, Commentary on Romans, 25.

54 CR 15:610; Melanchthon, Commentary on Romans, 120-21.

${ }^{55}$ BSELK 98; BC 38, 40.

${ }^{56}$ BSELK 287, 289; BC 128.

${ }^{57}$ BSELK 295; BC 131. 
and gracious on account of Christ, receives the forgiveness of sins, and justifies us." In the face of the terrors of conscience that recognition of sinfulness brings, "faith consoles and uplifts hearts, it regenerates us and brings the Holy Spirit that we might then be able to live according to the law of God, namely, to love God, truly to fear God, truly to assert that God hears prayer, to obey God in all afflictions, and to mortify concupiscence, etc." This faith receives forgiveness and recognizes that Christ has stilled the Father's wrath at sin. It does not try to argue God into being gracious with personal merit or deeds of love. It grasps Christ, renews the heart, and is the presupposition or basis for obedience to God's law in the believer's life. ${ }^{58}$

Not long after his arrival in Wittenberg, Melanchthon had recognized the nature of God's justifying Word as a promise. ${ }^{59}$ Melanchthon's Romans commentary of 1532 repeated his conviction that historical faith in what Christ did on earth must lead to assent to the promise of God's grace and then to "trust in his mercy, which has been promised for the sake of Christ." This trust includes wishing for divine comfort and for rest and safety in hearing that God is reconciled in Christ to his people. This faith is a noun which describes a relationship, and this trust throws itself in total dependence on God's promise in Christ. ${ }^{60}$ The righteousness of faith stands in contrast to the righteousness of works when human beings attempt to define what makes them righteous before God, but Melanchthon affirmed the practice of the works that indeed express faith in relationships to the rest of God's creation. ${ }^{61}$ Lecturing to students in 1532, he summarized the fruits of faith as recognition of the forgiveness of sins, reconciliation with God, and the gift of the Holy Spirit. Faith is not idle but receives the gifts of Christ's death and resurrection from the Spirit, destroying Satan's work and giving believers his aid. ${ }^{62}$

\section{Conclusion}

In the crisis-filled months following the diet of Augsburg in 1530, the Wittenberg reformers, especially Luther and Melanchthon, made special efforts to confess clearly what they regarded as the heart of the biblical message, the doctrine of justification by faith in Christ. In their lectures

\footnotetext{
58 BSELK 286; BC 127.

59 Ernst Bizer, Theologie der Verheißung: Studien zur theologischen Entwicklung des jungen Melanchthon, 1519-1524 (Neukirchen: Neukirchener Verlag, 1964).

${ }^{60}$ CR 15:514; Melanchthon, Commentary on Romans, 28-29.

${ }^{61}$ BSELK 276-87; BC 120-27.

62 CR 15:559-60; Melanchthon, Commentary on Romans, 71.
} 
both men clarified and developed this teaching, and Melanchthon focused on it in his Apology of the Augsburg Confession. They grounded their teaching in the re-creative Word of the gospel; its promise actually delivers forgiveness, life, and salvation. Faith's recognition of the reality of the passively bestowed righteousness in God's sight produces fruit in the active practice of righteousness in service and love for others in obedience to God's commands. 


\section{Luther and Erasmus: The Central Confrontation of the Reformation}

\section{JEAN-MARC BERTHOUD}

\section{Abstract}

One of Martin Luther's lasting achievements is his confrontation with Erasmus on the freedom of man's will. After first absorbing the nominalistic semi-Pelagian synthesis consensus, Luther revolted against the intellectual and spiritual mediocrity of that prevailing system of thought by using Ockham's logical razor and recovering biblical realism. The Bondage of the Will is the first confessional statement of the Reformation. Two opposing visions of reality emerge: Erasmsus's skepticism and semi-Pelagianism versus Luther's realism and the sovereign grace of God in salvation. However, there is a major breach in Luther's magnificent dogmatic achievement: in his doctrine of the two kingdoms the order of creation is abandoned to the initiative of man's thinking apart from the sovereign authority of Scripture.

\section{Introduction}

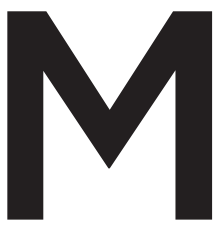

artin Luther has often been perceived, both from the Protestant point of view and by Roman Catholics, as a biblical theologian, but one whose philosophical underpinnings were resolutely nominalist with an Ockhamist rejection of universals. According to this interpretation Luther stands at 
the philosophical source of modern individualism, skeptical subjectivism, and rationalistic empiricism. His confrontation with Desiderius Erasmus on the issue of whether man's will is free to attain salvation shows that this perception of Luther's work is fundamentally incorrect. There is little doubt that Luther in his younger years was a partisan of the mitigated and eclectic nominalism of the late-fifteenth-century philosopher-theologian Gabriel Biel, which was prevalent in the schools and universities of his time. ${ }^{1}$ It is also clear that Luther later engaged in a fierce struggle against both the classical Pelagianism of William of Ockham (man must and can satisfy the demands of divine justice through his own freely accomplished works) and the semi-Pelagianism of Biel (man needs, in order to attain perfect justice, the assistance of God's grace to perfect the efforts of free will). For Biel, the first movement of man seeking God comes from the decision of his own free will, an initiative having no need of God's grace.

Such outright Ockhamist Pelagianism led Luther to despair: how could sinful man ever satisfy the perfect justice of a holy God? On the other hand, the spiritual mediocrity of Biel's semi-Pelagianism, with its drastic reduction of God's demands on man, disgusted him because of its negation of the holiness of God. Luther discovered the true nature of justice that Jesus Christ accomplished for us: incarnation on our behalf, perfect active obedience to the law of God, perfect passive submission to God's wrath for our sins on the cross, and the imputation of Christ's benefits to the repentant sinner. This liberated him from the futility of semi-Pelagianism. The justice of Christ, unattainable by human efforts, Luther discovered to be the free gift of the grace of God (sola gratia) accessed through belief in Christ (sola fide) and by the sovereign free action of the Holy Spirit (soli Deo gloria).

This conflict stood at the heart of the war Luther engaged against late medieval scholasticism. The incisive logic of William of Ockham-his famous "razor," the sharpest of tools - came to good use, so that Luther gradually came to rid himself of the teachings that had obscured the plain teaching of the Bible. Here also, the philological criticism developed in the course of the fifteenth century by humanists such as Lorenzo Valla and, later, by Erasmus himself, came in good stead. Luther labored to remove the crust of erroneous readings of Scripture accumulated over the centuries, whose dogmatic force rendered impossible the submission of repentant sinners to the Word of God (sola Scriptura) for salvation.

1 Heiko Oberman, The Harvest of Medieval Theology: Gabriel Biel and Late Medieval Nominalism (Cambridge: Harvard University Press, 1963). 
Erasmus did not move beyond the literary philological criticism of the text, but this is not the case with Luther. For Erasmus this discipline led first to philosophical skepticism and later to dogmatic uncertainty, even regarding the teachings of the Roman Magisterium. Luther, on the other hand, went beyond this approach. Once he had freed himself, by a prodigious intellectual and spiritual struggle, from the crust of the false dogmas of late medieval Roman Catholicism, he brought into action a very different epistemological and metaphysical virtue: a remarkable biblical and doctrinal realism. Once the pruning knife of Ockhamian logic and humanist philological criticism had done its work, Luther, unlike Erasmus, turned to creative labors: the deduction, from the recovered text and the exact meaning of the Scriptures, of a dogmatic and systematic framework faithful to the biblical rule of faith. It is here that we discover the true Luther, a realist thinker of the highest order capable of drawing from the Bible its true meaning. It is this epistemological and metaphysical realism, that of the Bible itself and of the normal use of the intelligence, which renders the modest and humble student capable of discerning the biblical universals that structure the order of creation. Both Protestant and Roman Catholic misconceptions of Luther's achievement proceed from an incapacity to distinguish between the two stages of his work; the first was nominalist, the destruction of erroneous notions imposed on Scripture, the second realist, the constructive, creative rediscovery of the exact theological content of the Bible.

Luther was thus not the adversary of right reason but of its sophistic misuse. In The Bondage of the Will he pushes sound logic to its limits and carefully shows to what extent Erasmus's reasonings are incoherent, both in themselves and with regard to the plain grammatical and logical sense of Scripture. ${ }^{2}$ Luther proves to be the father of the spiritual realism of our confessionally Reformed heritage, sounding the trumpet that for two centuries gave a faithful note to the orthodox, catholic, and apostolic Christian faith. In this respect we may learn from another spiritual giant, Pierre Courthial, who clearly perceived the confessional character of the sixteenth and seventeenth centuries:

Neither the first ecumenical councils, with their Trinitarian and Christological declarations, nor the confessions of the Reformation with their soteric and Scriptural affirmations, invented new doctrines supplanting the words of Holy Scripture. They only preserved, in giving them greater precision, the Fides catholica e Scriptura fluens (the Catholic Faith proceeding from Scripture), this in contradiction to the

2 Martin Luther, The Bondage of the Will, trans. J. I. Packer and O. R. Johnston (Cambridge: James Clarke, 1973) includes an important introduction. 
innumerable and ever renascent heresies which threaten the Christian faith, preserving thereby soli Deo gloria (To God alone all Glory!), that indeed,

God alone is Lord and Savior,

There is none other but him. ${ }^{3}$

\section{With What Did Luther Reproach Erasmus?}

We shall now turn, after a few introductory remarks, to Luther's biblical and theological polemic against Erasmus's Diatribe with Regard to the Freedom of the Will. ${ }^{4}$ There had been, for a number of years, an uneasy alliance between Erasmus of Rotterdam, the universally admired humanist, and Luther, the theologian-preacher of the University of Wittenberg, Erasmus had, however, become anxious at Luther's growing polemic with the Church of Rome. Erasmus had long campaigned for a return to the "simplicity of the gospel" and for a radical internal correction of the structure of the Roman Church and its sacraments, but he gradually found Luther's stringent demands more than disturbing. Erasmus was caught between his desire for a limited renewal of the church, for which he had found an ally in Luther, and the growing demand of the papal hierarchy that he take a clear stand against the Wittenberg firebrand. ${ }^{5}$

On his side Luther was increasingly dissatisfied by Erasmus's all-toohuman conception of the Christian faith. In a letter dated March 1, 1517the year of the Ninety-Five Theses - Luther wrote to a friend, "I am reading our Erasmus and I like him less and less." And on May 28, 1522, Luther, thinking of Erasmus, wrote again, "Truth is stronger than eloquence, inspiration is worth more than brilliance, faith is superior to erudition." ${ }^{\prime 7} \mathrm{He}$ had well perceived the humanist's love for peace at all costs. On October 19, 1521, Erasmus wrote to a friend, "If the church had adopted Arianism or Pelagianism, I would also have adopted them." "I do not have the mettle for martyrdom." But the call for Erasmus to take

3 Pierre Courthial, Le jour des petits recommencements (Lausanne: L'Âge d'Homme, 1996), 176-77. Our translation. The English version of this masterpiece should shortly be published by Zurich Publishing as $A$ New Day of Small Beginnings (Tallahassee, FL: Zurich Publishing, forthcoming), http://www.zurichpublishing.org/\#!a-new-day-of-small-beginnings/irk81.

4 Érasme de Rotterdam, Essai sur le libre arbitre, ed. Pierre Mesnard (Alger: Robert \& René Chaix, 1945). "Erasmus, A Discussion or Discourse concerning Free Will (1524)," in Clarence H. Miller et al, Erasmus and Luther:The Battle over Free Will (Indianapolis: Hackett, 2012), 1-31.

5 On this Erasmian dilemma, see Marie Barral-Baron, L'enfer d'Érasme: L'humaniste chrétien face à l'histoire (Geneva: Droz, 2014).

6 Mesnard, Essai sur le libre arbitre, 39.

7 Ibid., 43.

8 Ibid., 44. 
a stand publicly and choose the side he stood for became more and more insistent. In 1524 Luther offered not to write against him, asking of Erasmus that he take a neutral position. But the pressure from Rome became too strong, and in September 1524 Erasmus published his diatribe De libero arbitrio diatribe sive collatio (Discourse Concerning Free Will). It was a clear declaration of hostilities. Luther's reply, the De servo arbitrio (Bondage of the Will), was published over a year later, in December 1525. Between Luther and Erasmus there could now be no conciliation!

Let us now turn briefly to the philosophical, biblical, and theological polemic in which Luther engaged with regard to Erasmus's Discourse Concerning Free Will. Luther starts by placing the debate squarely on the necessity for an affirmative intellectual attitude so that certainty of knowledge in the practice of theology be attained. We must, affirms Luther, reject Erasmus's nominalist and empirical skepticism so that we can reach certainty as to the doctrine we deduce from Scripture. We must tend to a confessional faith - to a dogmatic certitude, in other words-one that manifests and confesses verbally the eternal and immutable doctrine of revealed truth. Luther's first attack is thus directed against Erasmian skepticism.

Luther understands full well that Erasmus seeks to defend theological agnosticism —we would today speak of a "nondoctrinal position" - in order to promote ecclesiastical and social peace. But what kind of peace does this imply, and what would be the cost? Luther replies, "To take no pleasure in assertions is not the mark of a Christian heart; indeed, one must delight in assertions to be a Christian at all." To make his meaning absolutely clear, he adds, "Now, lest we be misled by words, let me say here that by 'assertions' I mean staunchly holding your ground, stating your position, confessing it, defending it and persevering in it unvanquished." ${ }^{\prime 9}$ Luther sets aside Erasmus's recommendation not to engage in futile discussions. $\mathrm{He}$ addresses himself directly to Erasmus:

What Christian can endure the idea that we should deprecate assertions? That would be denying all religion and piety in one breath - asserting that religion and piety and all dogmas are just nothing at all. Why then do you-you! assert that you find no satisfaction in assertions and that you prefer an undogmatic temper to any other? ${ }^{10}$

In fact, for Erasmus the question of the capacity or incapacity of man to save himself, whether his will is free or enslaved, stood among what he calls "pointless, unnecessary questions" that one could agree to ignore, to set

\footnotetext{
9 Ibid.
}

10 Ibid. 
aside as of indifferent interest. But for Luther this was a matter of eternal life or death. For him it was of capital importance to know if God's prescience is contingent - that is, dependent on future variable and unpredictable events - or if God's prescience is absolute, necessary, and immutable. Luther pursues his demolition of Erasmus's sophistry:

Here you are, a theologian, a teacher of Christians, now about to write for their guidance an outline of Christianity, and not merely do you vacillate, in your skeptical way, as to what is profitable and necessary for them, you go back on yourself, defy your own principles and make an assertion - an unheard-of assertion - that here is something non-essential. ${ }^{11}$

Luther adds that if it is not essential to know what would be useful or not useful for the Christian's salvation, "then there is neither God, Christ, the gospel, faith nor anything else even in Judaism, let alone Christianity, [that] is left!" This is where Erasmus's nondoctrinal Christianity - and the present rejection of doctrinal norms - ends up. Luther now develops his demonstration of the fatal consequences of Erasmian skepticism. He starts with his Pelagianism:

The outline of Christianity which you have drawn up contains, among other things, this: "We should strive with all our might, resort to the healing balm of penitence, and try by all means to compass the mercy of God, without which man's will and endeavour is ineffective."

\section{Luther comments,}

The Christ-less, Spirit-less words of yours are chillier than very ice. ... This is what your words assert: that there is a strength within us; there is such a thing as striving with all one's strength; there is a mercy in God; there are ways of compassing that mercy; there is a God who is by nature just; and so on. But if one does not know what this strength is - what men can do and what is done to them-what this "striving" is, and what is the extent and limit of its effectiveness-then what should he do? What will you tell him to do? ${ }^{12}$

In these passages Luther attacks his adversary's skepticism. Erasmus, who declares that "it is irreligious, idle, and superfluous to want to know whether our will effects anything in matters pertaining to eternal salvation," nonetheless asserts, according to his Pelagian credo, just the contrary. ${ }^{13}$

\footnotetext{
${ }^{11}$ Luther, The Bondage of the Will, 75.

${ }^{12}$ Ibid.

${ }^{13}$ Ibid., 76.
} 
Luther thus affirms the Christian doctrine of divine foreknowledge, of the total foresight of God for every event in time and space, from Erasmus's own words, from popular wisdom and, finally, from the Bible itself. Luther thus affirms this vital doctrine:

It is, then, fundamentally necessary and wholesome for Christians to know that God foreknows nothing contingently, but that he foresees, purposes, and does all things according to His own immutable, eternal and infallible will. This bombshell knocks "free-will" flat, and utterly shatters it; so that those who want to assert it must either deny my bombshell, or pretend not to notice it, or find some other way of dodging it. ${ }^{14}$

After having shown by Erasmus's own words, by the futile character of certain distinctions, and by popular wisdom, the existence and the necessity of divine providence, Luther shows Erasmus the consequences of his skepticism:

If then, we are taught and believe that we ought to be ignorant of the necessary foreknowledge of God and the necessity of events, Christian faith is utterly destroyed, and the promises of God and the whole gospel fall to the ground completely; for the Christian's chief and only comfort in every adversity lies in knowing that God does not lie, but brings all things to pass immutably, and that His will cannot be resisted, altered or impeded.

\section{Luther then addresses his adversary directly:}

Observe now, my good Erasmus, where that cautious, peace-loving theology of yours leads us! You call us back, and prohibit our endeavours to learn about God's foreknowledge and the necessity which lies on men and things, and advise us to leave behind, and avoid, and look down on such inquiries; and in so doing you teach us your own ill-advised principles - that we should seek after ignorance of God (which comes to us without seeking, and indeed is born in us), and so should spurn faith, abandon God's promises, and discount all the consolations of the Spirit and convictions of our conscience. Epicurus himself would hardly give such advice! ${ }^{15}$

\section{Luther closes this section of his book by calling Erasmus to repentance and to a return to God:}

It is no game and no joke to teach the holy Scriptures and godliness, for it is so very easy to fall here in the way that James described: "He that offends at one point becomes guilty of all" (2:10). For when we show ourselves disposed to trifle even a little and cease to hold the sacred Scriptures in sufficient reverence, we are soon involved in impieties and overwhelmed with blasphemies - as you are here, Erasmus. May the Lord pardon and have mercy on you. ${ }^{16}$

\footnotetext{
14 Ibid., 80.

15 Ibid.

16 Ibid., 85.
} 


\section{The True Nature of the Conflict between Luther and Erasmus}

The French historian of the Reformation Jean Boisset, in his study on the conflict between Luther and Erasmus on free will, seeks to show the contrast between the two great figures of the religious and political history of the early sixteenth century. He describes the "two ways"-which structure the whole of the history of God's covenantal dealings with mankind - as they impinge on the lives of these two central figures:

But there were two ways. The guides on this journey were Erasmus and Luther, both witnesses of their time; the one animated by the euphoric anxiety attached to the erudite study of human reality, Erasmus; the other, Luther, filled with that tragic anguish of man who seeks to accomplish the will of God. ${ }^{17}$

We have seen that Luther's Bondage of the Will manifests a newly rediscovered confessional faith, faith brought to light by the unwearied realist battle against error. It is thus that the heralds of the faith of the Reformation showed themselves, by their unchangeable confessional standards, to be the rightful and worthy inheritors of the fathers who formulated the creeds of the fourth and fifth centuries. On the other hand, to echo the title of another work, we could say that Erasmus's Diatribe represents the "critical Christianity" of modern times. ${ }^{18}$ The great Erasmian scholar Augustin Renaudet aptly titles an important chapter of his Erasmian Studies "Le modernisme érasmien." ${ }^{19}$ Where Luther submits his reason to the divine authority of holy Scripture, Erasmus for his part, submits the holy books to the liberty of the critical reason.

Luther was scrupulous to the extreme in his disciplined life as a monk. $\mathrm{He}$ entered his vocation under the constraint of a binding vow, abandoning himself passionately to the limits of physical and moral exhaustion to the obedience demanded by the monastic rule. It was thus that he hoped to find peace with a God justly angered by his sins. It was during his time as a monk that Luther-in contradiction to what has so often erroneously been written of him - became the accomplished philosopher to which his Bondage of the Will so eloquently witnesses. Boisset excellently describes his period in his life:

${ }^{17}$ Jean Boisset, Érasme et Luther: Libre ou serf arbitre (Paris: Presses Universitaires de France, 1962), 6 .

${ }^{18}$ Pierre Mesnard, Érasme ou le christianisme critique (Paris: Seghers, 1969).

${ }^{19}$ Augustin Renaudet, "Le modernisme érasmien," in Études érasmiennes (1521-1529) (Geneva: Droz, 1939), 122-89. 
He entered the convent seeking to find appeasement to the inner torment which burned his soul. Deeply troubled by the teaching he had received, he could find no way to balance the sovereign holiness of God with the unbearable weight of his own sin. "In such moments, he writes, God appears frightfully angered and the whole creation takes on this hostile appearance." Luther knew within himself a crucifying anguish, and it was to appease this torture that he chose to become a monk. ${ }^{20}$

Léon Chestov also describes Luther's attitude at this time very accurately:

Whatever Protestants may say, Luther took this fateful resolution [of entering the monastery] because he believed in the exclusive perfection of the monastic life and that, by conforming himself to such a model of perfection, he would come to please God and to merit both forgiveness and eternal life. ${ }^{21}$

For Erasmus, things went otherwise, indicates Boisset:

Erasmus in Steyn had a very different experience. ... No doubt at Steyn, as in Erfurt, one read the Bible, the fathers and the mystics. Only, whilst the Augustinian monk in Erfurt was abandoned to his search of salvation, aiming more for holiness rather than for wisdom, Erasmus, the Augustinian in Steyn, sought after secular wisdom rather than for holiness. ${ }^{22}$

Boisset adds, "Thus it is no surprise not to find in all his correspondence in Steyn a single mention of Jesus Christ." ${ }^{23}$ He compares the two monastic experiences:

For Erasmus the time in the Augustinian monastery of Steyn was a period of study where he diagnosed the miseries of the present and the glories of ancient times; where he acquired a culture which the years to come would allow him to exploit; where he emerged unchanged in his convictions and confirmed in the orientation of his life. For Luther his time in Erfurt was a battle of three years where he diagnosed man's eternal misery; where he went through a spiritual experience which, in the years to come, would spread like wildfire throughout Europe; wherefrom he would emerge "altogether changed" and ready to "Gott Leiden," to "suffer God."24

Both Luther and Erasmus were attached to the principle of a return to the sources, ad fontes, the search for the foundational texts; both were part of the drive for renewal; both were precise grammarians and, as we shall shortly discover, Luther far surpassed Erasmus. But if for Erasmus the aim

${ }^{20}$ Boisset, Érasme et Luther, 12.

${ }^{21}$ Léon Chestov, Sola fide: Luther et l'Église (Paris: Presses Universitaires de France, 1957), 81.

${ }^{22}$ Boisset, Érasme et Luther, 14-15.

${ }^{23}$ Ibid., 15-16.

${ }^{24}$ Ibid., 17. 
was the renewal of the study of literature; for Luther it was to rediscover the saving truth of God in Jesus Christ, in the witness of Holy Scripture. How then did Erasmus and Luther read the biblical text? Let us start with Luther.

After a careful examination of Erasmus's arguments, Luther brings to our attention their logical and grammatical shortcomings. He then turns to the study of scriptural justification, which the great humanist put forward to defend his thesis of man's exercise of "free-will" in the acquisition of salvation. Boisset indicates Luther's basic question: "What do the biblical passages brought forward by Erasmus really signify? In fact the very opposite of what he affirms! Erasmus has clearly not understood the meaning of the passage he quotes." For Luther, writes Boisset, "Erasmus has not understood what the words 'wage' and 'reward' mean in the Bible: there is a recognition, a due, in favor of good will. However, if the Bible 'shows that the wage is necessary,' it does not show 'that we merit it by our dignity." 25 Luther explains his position:

Wherefore, as the words of the law serve their own turn by instruction and illumination, to teach us what we ought to do and what we cannot do, so the words of reward, signifying what is to be, serve their turn by exhorting and threatening, and animate, comfort and uphold the godly to press on, persevere and triumph in doing good and enduring evil, lest they be wearied, or their spirit broken. ${ }^{26}$

In conclusion, Boisset writes,

But Erasmus does not know how to read the Word of God. He can neither read it according to the Spirit nor according to its grammar [the letter]. And Luther then undertakes to give the humanist a lesson in exegesis in order to obtain a correct version of a fragment of Romans 9:18: "Therefore hath he mercy on whom he will have mercy and whom he will he hardeneth." 27

Here is Luther's exegetical aim:

We are not enquiring whether one could employ it [in a figurative sense] to explain this passage in Paul; our question is, whether we may with safety and certainty suppose that we are correct in invoking it to explain this passage, and whether Paul meant to use it here. ${ }^{28}$

\footnotetext{
25 Ibid., 66.

${ }^{26}$ Luther, The Bondage of the Will, 183.

27 Boisset, Érasme et Luther, 67.

28 Luther, The Bondage of the Will, 193.
} 
Boisset goes on to add, "We must thus respect the literal meaning of the text and express precisely what it says and not what it intends or what it could say." 29

In the spirit of grammatical and exegetical realism, for Luther the words of the biblical text truly refer to the reality named:

Everywhere we should stick to just the simple, natural meaning of the words, as yielded by the rules of grammar and the habits of speech that God has created among men; for if anyone may devise "implications" and "figures" in Scripture at his own pleasure, what will all Scripture be but a reed shaken by the wind, and a sort of chameleon? ${ }^{30}$

\section{Luther adds,}

There would then be no article of faith about which anything could be settled and proved for certain, without your being able to raise objections by means of some "figure." All "figures" should rather be avoided, as being the quickest poison, when Scripture itself does not absolutely require them. ${ }^{31}$

What would Luther say today about the irrational and ungrammatical critical and hermeneutical hawks who prey on the text and meaning of Scripture? He continues:

I have noticed that all heresies and errors in handling the Scriptures have come, not from the simplicity of the words, (as almost all the world tells us), but from not regarding the simplicity of the words, and from hankering after figures and implications that come out of men's own heads. ${ }^{32}$

Luther then explains how Erasmus, in his interpretation of the biblical text, abuses the elementary rules of grammar:

And when these "explanations," which no grammarian could tolerate, occur in theologians, they may not be called violent and arbitrary; they are "the views of the most respectable and time-honoured doctors." The Diatribe is easily able to sanction and pursue figures at this point, for it is indifferent as to whether what is said is sure or unsure. Indeed, it aims to have all things unsure, for it advises that the doctrines concerning "free-will" should be left alone and not investigated. Hence it would be satisfied with any way of warding off of statements by which it felt itself embarrassed. ${ }^{33}$

${ }^{29}$ Boisset, Érasme et Luther, 67.

${ }^{30}$ Luther, The Bondage of the Will, 192. Boisset, Érasme et Luther, 67.

${ }^{31}$ Luther, The Bondage of the Will, 192.

${ }^{32}$ Ibid.

${ }^{33}$ Ibid., 193. 
How prophetic is Luther! This is exactly what critical exegesis (Arminian, antinomian, theistic evolutionist, dispensational, fundamentalist, Pentecostal, or Roman Catholic) has, at different times, been doing to Scripture for the past four hundred years, without always finding a reply from Christian theologians comparable to this indignant, and extraordinarily accurate, apologetic satire, which is an amazing example of a true defense of the faith! Luther's conclusion we make our own: "But for me what is in hand is a serious matter; I want to be as sure of the truth as I can, in order to settle men's consciences; and I must act far differently." ${ }^{34}$ And he adds,

On what authority, and to what purpose, and by what need, is the natural meaning of the passage thus distorted? What if the reader is astray in his explanation? How is it proved that his distortion of the words in this passage is correct? It is both dangerous and impious to wrest the Word of God without authority and without need. ${ }^{35}$

\section{Luther and Nominalism}

Luther made generous use of his nominalist heritage in demolishing the eclectic, skeptical theological system that marked his thinking as a student. But here we must add some qualifications. The citations from The Bondage of the Will reveal the extraordinary grammatical and semantic biblical realism that characterized Luther's exegesis. For him Christian doctrine-the dogmas of the faith - must at all times correspond with the greatest exactitude to the conceptual and spiritual content of Scripture. Nevertheless, in his refutation of Erasmus's pseudo-biblical (and pseudo-grammatical!) arguments, Luther used certain Ockhamian concepts, in particular concerning the "two kingdoms" and the distinction between the hiddenness of God and God's accessible revelation (Deut 29:28). The latter was charged with Ockhamian overtones, opposing speculatively the absolute power of the divinity, as above the law, and God's ordained justice, as finding its expression in the revealed law. ${ }^{36}$

The distinction between the absolute power of God (potestas absoluta), only limited by the principle of noncontradiction, and his ordained power (potestas ordinata), as manifest in the revealed Word of God and the order of creation, was understood by Luther in submission to the teachings of the Bible. He categorically refused to follow the abstract speculative path

\footnotetext{
${ }^{34}$ Ibid.

${ }^{35}$ Ibid., 194.

${ }^{36}$ David Steinmetz, "Luther and the Hidden God," and "Luther and the Two Kingdoms," in Luther in Context (Grand Rapids: Baker, 1995), 23-31 and 112-25. André de Muralt, L'unité de la philosophie politique de Scot, Occam, Suarez au libéralisme contemporain (Paris:Vrin, 2002).
} 
opened by Ockham to justify the idea of an absolute divine power considered as unrelated to his other attributes.

However, Luther was not as biblically clear in his dualistic nominalist distinction between the "two kingdoms." His distinction concerns what in his view is under God's realist direct authority and what God seems to leave to the subjective autonomous empirical authority of man. Careful study of the Augustinian tradition shows that this dualism draws its source in a remnant of Manichaean and Plotinist influence in Augustine's thinking. To better understand both Luther's thought and what he reproached Erasmus with, a text from Ecclesiasticus he discusses is interesting: "So we learn from Ecclesiasticus that 'man falls under two kingdoms.' In the one, he is led by his own will and counsel, not by any precepts and commandments of God; that is, in the realm of things below him." ${ }^{37}$ So the order of the world is divided into two kingdoms: one of grace, governed directly by God, and the other of nature, governed by man, the latter being however under a certain control exercised by God. Luther, yielding here to Ockham, recognizes two kingdoms; the one contains "those things below him": matter, vegetable, and animal life, and also, to some degree, politics. This kingdom remains, to a certain extent, autonomous from God. Man can himself, by the exercise of his will, choose between good and evil, establish moral distinctions and those founding the metaphysical principles of the material universe (Gen 2:2-3).

In this distinction lies the seed for openness in favor of the future autonomous development of the new sciences of nature. Thus for Luther there is no question - this in opposition to the whole Christian tradition prior to Ockham - of seeking to bring every thought of man captive to the obedience of Christ (2 Cor 10:5). If Luther is indeed fully apostolic in his understanding of the biblical doctrines concerning salvation, he is, on the other hand, insufficiently catholic in his Christian thinking concerning the natural world. For, according to him, there exists a domain in the natural world, "of things below him," which man "governs according to his own counsel." In fact, for Luther this is the counsel of man and no longer that of God.

Here is a spectacular return in Luther's thinking of Erasmus's free will and, with it, a way opened for the secularization — without God's norms - of the whole temporal domain; the liberal freeing of man from necessary submission to the obligatory authority of divine laws over that order of nature God created and ordained. We see firsthand Luther's lack of understanding,

\footnotetext{
${ }^{37}$ Luther, The Bondage of the Will, 150. It is interesting that Luther draws his argument from an apocryphal text.
} 
both of the creational order as fully belonging to God and of the revealed laws established by the Creator for his creation by which he set limits for man's exercise of the creation mandate.

Luther thus affirms that the gospel leaves us free to use, or not to use, external matters such as food, drink, and so forth as we see fit. However, even in such apparently external matters, God has established a framework with regard to what we drink and what we eat, limiting the absolute freedom of our appetites and passions by certain biblical alimentary and other rules; for example, he restrains (but does not forbid) our consumption of alcoholic beverages and limits our free technocratic use and abuse of the natural realm.

Luther now turns to the domain of "theology," that is, to the "spiritual kingdom," the realm precisely ordered by God, through his potestas ordinata. This he does in the most realist of manners, explaining with remarkable attention the conceptual content of the biblical text, the infallible authority of the Word of God. However, are the material, the vegetable, and the animal domains of creation not also, each in its proper sphere, fully part of the "kingdom of God"? Luther writes as if, in the "temporal" or "secular" spheres, man could, of himself, "as god" determine good and evil as well as the first principles of creation! ${ }^{38}$

It is in this specific "realm of God," that of the "gospel," and not in that of the "law," in the domain of ultimate realities, of heavenly things and not in that of penultimate, earthly realities, that Luther shows a remarkable gift for biblical and spiritual realism. It is here we can see a real continuity between that wonderful confessional text, The Bondage of the Will, and the Reformed confessions and catechisms of the sixteenth and seventeenth centuries, culminating, on the one hand with the Canons of Dort, and, on the other, with the documents of Westminster, in direct biblical continuity with the creeds of the faith of the ancient church.

A concluding passage of our text witnesses even more clearly to Luther's persistence, in an important part of his writings, in his attachment to the nominalist dualism of his earlier years. "As in his own kingdom he is led by his own will, and not by the precept of another, so in the kingdom of God he is led by the precept of another, and not by his own will." ${ }^{39}$ That is, man is led by his own choice without exterior divine direction, either of the law of God, that of the created order, or the external human authority of the Roman Church. It is this purely subjective human choice that Luther here wrongly opposes to the external objective choice of God, which concerns

38 Jean-Marc Berthoud, Création, Bible et science (Lausanne: L'Âge d'Homme, 2008).

${ }^{39}$ Luther, The Bondage of the Will, 151. 
man's salvation, as expressed in the Gospel and, in particular, in the New Testament itself.

\section{Conclusion: The Heart of the Reformation, the Confessions of Faith}

There can be little doubt that the religious and educational revival associated with the lay movement of the Brethren of the Common Life played a capital role in the preparation of the Reformation. But for the Reformation to develop into a lasting ecclesiastical form it was essential to return to the ancient dogmatic expression of the faith. Only a normative doctrinal confession could give a permanent biblical structure to the nascent communities in a phase of inchoate revival. The first step in this direction was the publication of Luther's masterly refutation of Erasmus's Diatribe. The Bondage of the Will was the first and, perhaps, the most important confessional document of the Reformation.

From a philosophical point of view, it represented the defeat - in principle, even if only partial and temporary - of the eclectic nominalism that had dominated European thought and religion during the fourteenth and fifteenth centuries. Against Erasmus, universals were re-established by Luther in the form of a dogmatic confessional and polemical statement, articulated in realist conformity to the content of the Scriptures that can be expressed conceptually. In contrast to Luther, as a precursor of modern liberal thinking, Erasmus remained, to a large degree, faithful to the essentially nondoctrinal-moral, voluntarist, and intellectual-renewal of the late Middle Ages so characteristic of the Brethren of the Common Life. He did not break with the semi-Pelagian vision of Biel.

For the Reformation to flourish and take root this multiform nondoctrinal renewal of piety had to be canalized in specific doctrinal directions, either that of a biblical and ecclesiastically faithful doctrinal tradition represented by Luther and the Calvinist movement on the one hand, or on the other by the later hyper-Romanist Jesuit order founded by Ignatius of Loyola. It is here that Luther's Bondage of the Will played such a decisive role, sounding with the greatest clarity and force the trumpet of the true and full-blooded gospel. One of the most remarkable fruits of Luther's work of doctrinal formulation of the "faith delivered once and for all to the saints" (Jude 3) was the astonishing blossoming throughout Europe of innumerable, and largely unanimous, Reformed confessional statements and catechisms. A tremendous intellectual and spiritual effort-comparable to the Symbolic Confessions of the fourth and fifth centuries-recovered the doctrinal 
content in a revival of what Heinrich Bullinger called the "Old Faith," in strict conformity with the intellectual content of the Scriptures. ${ }^{40}$

In seeking to destroy philosophically the reality of universal categories, Ockham made doctrinal and dogmatic reading of Scripture impossible for those in the nominalist and empirical tradition, so destroying intellectual access to the substance of Scripture. He opened the way for the subjectivist atomization of the biblical text into a medley of innumerable isolated pericopes without any structural relation one to another. In this sense Ockham, like Erasmus some two centuries later, was a precursor of the historicocritical method of modernism, which destroys the coherence (the unity of divine authorship and truth) of the written and infallible Word of God. ${ }^{41}$ In this way the unity of meaning of the Bible-its truth, a systematic coherence within the ultimate transcendent reference of meaning - was broken.

Thus the prodigiously intelligent, complex-open to transcendence and coherent-structure of the Bible, both in its meaning and in the light it sheds on God's creation and on providential history, was destroyed. In its place was established the stunted intelligence of the solitary critical biblical scholar. This biblical critic - of whom Erasmus became the model ${ }^{42}$ substituted for the unity of the revealed creational and redemptive design of the only true God, Father, Son, and Holy Spirit, the infinitely subjective and irrational fantasies of the critical scholar. However, God-given and God-restored intelligence is capable, by the illumination and sanctification of the Holy Spirit, of modestly comprehending, within those creaturely limits, the divinely accommodated meaning both of the Scriptures and (through the Scriptures) of God's created and providential reality. For the Trinity, the almighty, just, and loving God is the author, not only of the Scriptures but also of creation and history! With his infallibly inspired and fully human instrument - the sixty-six books of the Bible-God has given his church the canonical Scriptures, which contain the whole divine Word (tota Scriptura) necessary for the upbuilding and obedience of the church and for the salvation of the world, the re-creation of the elect and, through them, that of the created and fallen cosmos.

It was Luther's great achievement with that prophetic trumpet call, The Bondage of the Will, to restore to the Christian church the heritage of its

${ }^{40}$ See the forthcoming article by Joe Mock, "Bullinger's The Old Faith (1537) as a Theological Tract," Unio cum Christo 3.2 (October 2017).

${ }^{41}$ To a lesser degree, such strictures may also be applied to the literalistic, univocal, and binary fragmented reading of Scripture that we find in fundamentalist dispensationalism.

${ }^{42}$ On the tradition of Erasmian studies, see Bruce Mansfield's trilogy, Interpretations of Erasmus (Toronto: University of Toronto Press, 1979-2003). 
ancient intelligence of God's Holy Word. This orthodox, catholic, and apostolic approach to the Bible can, and will, restore to those who both fear and love God, the life-giving and true meaning of the Bible. May God-as he was with Martin Luther in the sixteenth century-continue to be glorified in his church today by the fruits of this majestic achievement. 



\title{
An Introduction to Luther, Calvin, and Their Protestant Reformations
}

\section{PETER A. LILLBACK}

\begin{abstract}
A comparison of Martin Luther and John Calvin shows that they stand in line with historic Christianity and share core Reformation principles. Abuses in the Catholic Church and indulgences are among the main reasons why Luther broke with the church in which he grew up. Luther gave the impetus for other Reformations and theological movements, in particular Zurich, represented by Heinrich Bullinger with his contribution to covenantal thought, and Geneva, where Calvin through his Institutes crystallized Reformed theology. While Luther showed some appreciation for Calvin, Calvin, without idealizing Luther, acknowledged his towering influence. Luther and Calvin left their mark in areas such as theology, the church and worship, society, and Western history and culture.
\end{abstract}

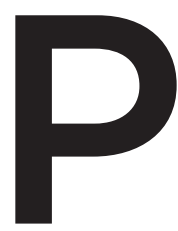

rotestants generally trace their origins to Martin Luther. Some can do so personally. John Wesley in his journal described how on May 24,1738, at about 8:45 p.m., he was converted as his heart was "strangely warmed" while listening at Aldersgate Street to a reading of Luther's preface to the Epistle to the Romans. ${ }^{1}$

1 "In the evening I went very unwillingly to a society in Aldersgate Street, where one was reading Luther's preface to the Epistle to the Romans. About a quarter before nine, while he was describing the change which God works in the heart through faith in Christ, I felt my heart 
John Bunyan was impacted by reading Luther's commentary on Galatians, finding his own experience "largely and profoundly handled, as if [Luther's] book had been written out of my own heart."2 Martin Luther King Jr. not only bore the name of the Reformer, but appealed to Luther the "extremist" in his epoch-making Letter from Birmingham fail. ${ }^{3}$

Many Protestants also recognize a connection with John Calvin. Yet Calvin too affirmed his spiritual roots in the theology of Luther. In Calvin's estimation, Luther was "an eminent servant of God," as well as "a distinguished apostle of Christ by whose ministry the light of the gospel has shone." 4 Calvin was greatly impacted by Luther's life and teaching. Brian Gerrish explains,

A glance at the first edition of Calvin's Institutes, already published in 1536, is sufficient to prove that he was deeply indebted to Luther. ... Quite apart from the fact ... that Calvin modeled the structure of his first edition on Luther's catechisms, he borrowed freely from the fund of Lutheran ideas, not least on the Lord's Supper. His basic understanding of what a sacrament is unmistakably echoed the classic treatment in Luther's Babylonian Captivity. ${ }^{5}$

Here we want to introduce Luther and Calvin and their Reformations at this five-hundredth anniversary of Luther's Ninety-Five Theses, which inaugurated the Protestant faith. Historically the name Protestant came from the protest that followers of Luther raised at the Diet of Speyer in 1529 against an action of the court denying the legitimacy of the Lutheran cause, which had been previously permitted in various regions of the empire. ${ }^{6}$ The name has broadened in meaning to include the protest of all the abuses of Rome. The word is derived from the Latin word, protestare,

strangely warmed. I felt I did trust in Christ, Christ alone, for salvation; and an assurance was given me that He had taken away my sins, even mine, and saved me from the law of sin and death." http://www.ccel.org/ccel/wesley/journal.vi.ii.xvi.html

2 Cited by Richard L. Greaves, Fohn Bunyan (Grand Rapids: Eerdmans, 1969), 18.

3 "But though I was initially disappointed at being categorized as an extremist, as I continued to think about the matter I gradually gained a measure of satisfaction from the label. ...Was not Martin Luther an extremist: 'Here I stand; I cannot do otherwise, so help me God."' Cf. Peter A. Lillback, Annotations on a Letter That Changed the World from a Birmingham fail (King of Prussia, PA: Providence Forum, 2013), 69-70.

4 John Calvin, Defensio adversus Pighium, as cited in John Calvin, Institutes of the Christian Religion, 2 vols., ed. John T. McNeill, trans., Ford Lewis Battles (Philadelphia: Westminster, 1960), 1057, n. 4. See also Friederich Bente, Historical Introductions to the Book of Concord (St. Louis: Concordia, 1965), 173-74.

5 Brian Gerrish, The Old Protestantism and the New (Chicago: University of Chicago Press, 1982), 31.

6 "Origin of the Word Protestant," About Education, http://europeanhistory.about.com/od/ reformation/p/proriginprot.htm. 


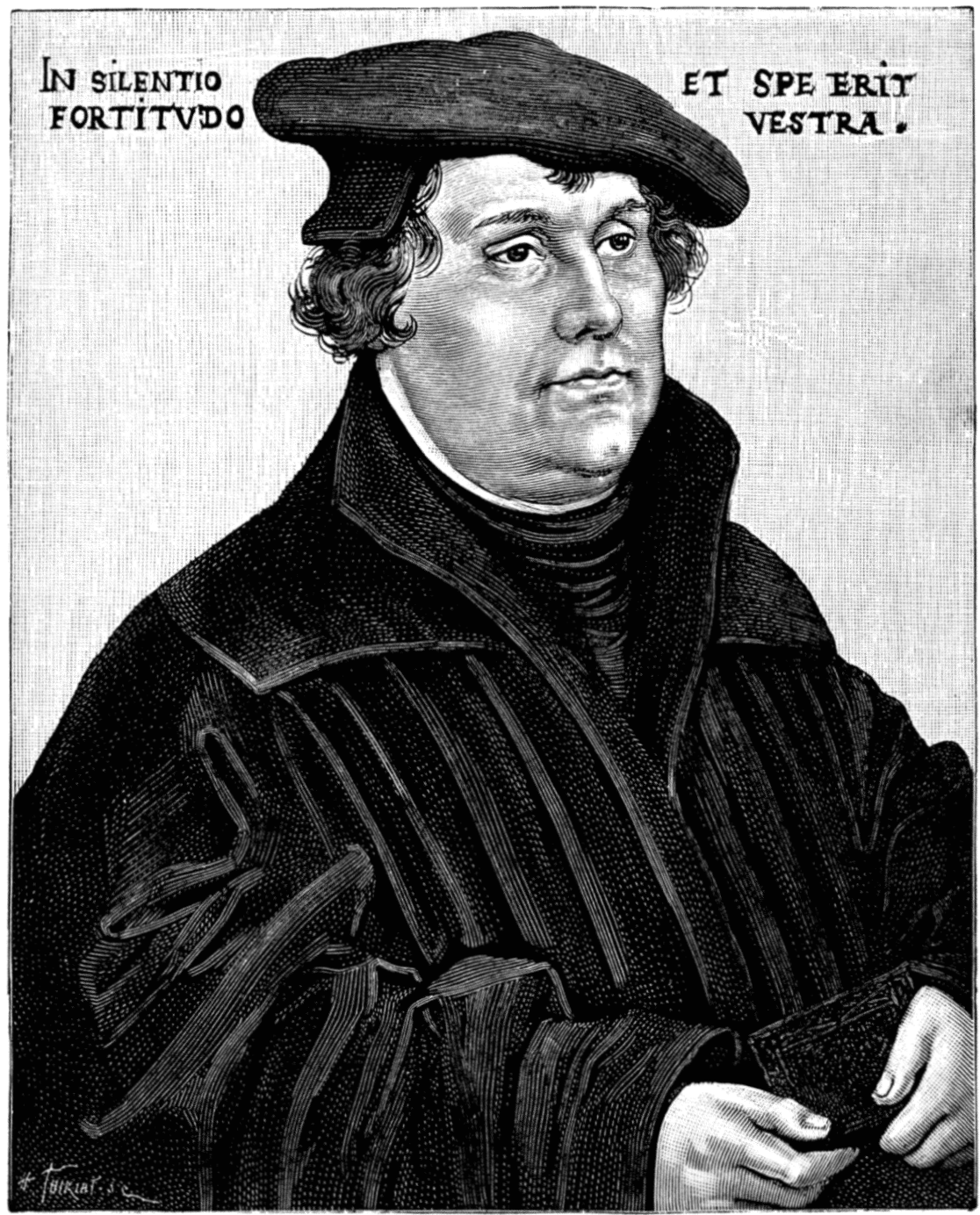

MARTIN LUTHER

1483-1546 
meaning "to witness toward," as in speaking about something that one has observed or believes to be true. It is here that the word Protestant finds its most noble significance.

\section{Forty Comparisons of the Lives and Ministries of Luther and Calvin}

To place Luther and Calvin in their historical contexts and to present some of the leading emphases of their theology, the following summary compares the lives and significant contributions of Luther and Calvin. ${ }^{7}$

\begin{tabular}{|l|l|l|}
\hline Comparison & Martin Luther & John Calvin \\
\hline 1. Reformation Dates & $\begin{array}{l}\text { 1st Generation } \\
(1483-1546)\end{array}$ & $\begin{array}{l}\text { 2nd Generation } \\
(1509-1564)\end{array}$ \\
\hline 2. Birthplace & Eisleben, Germany & Noyon, France \\
\hline 3. Father's work & Operator of a mine & Notary in church \\
\hline 4. Father's plans for son & $\begin{array}{l}\text { Law, but went to } \\
\text { monastery }\end{array}$ & $\begin{array}{l}\text { Submitted to study of } \\
\text { law }\end{array}$ \\
\hline 5. Ministry city & Wittenberg, Germany & Geneva, Switzerland \\
\hline 6. Royal actions toward & Protected in Germany & Exiled from France \\
\hline $\begin{array}{l}\text { 7. Political Conflict } \\
\text { 8. Training of Children }\end{array}$ & $\begin{array}{l}\text { Died before wars of } \\
\text { religion }\end{array}$ & Saw wars of religion \\
\hline 9. Schools & Started schools & $\begin{array}{l}\text { Started schools/ } \\
\text { academy }\end{array}$ \\
\hline 10. Bible & Translated Bible & Aided Bible translation \\
\hline 11. Scholarly Training & Theology, Bible & Law, classical literature \\
\hline 12. Scholarship & Prolific writer & Prolific writer \\
\hline 13. Health & Physically healthy & Physically ill \\
\hline $\begin{array}{l}\text { 14. What launched } \\
\text { ministry }\end{array}$ & Indulgences debate & Wrote Institutes \\
\hline 15. Ministry stability & Ministered in one place & $\begin{array}{l}\text { Three-year exile from } \\
\text { Geneva }\end{array}$ \\
\hline 16. Confession & Augsburg Confession & Gallican Confession \\
\hline
\end{tabular}

7 For recent contributions, see Carl Trueman, Luther on the Christian Life (Wheaton, IL: Crossway, 2015) and Herman Selderhuis, fohn Calvin: A Pilgrim's Life (Downers Grove, IL: IVP Academic, 2009). For a recent comparison between the two, see Jacques Blandenier, Martin Luther et fean Calvin: Contrastes et ressemblances (Charols: Excelsis, 2016). 


\begin{tabular}{|c|c|c|}
\hline Comparison & Martin Luther & John Calvin \\
\hline 17. Augsburg Confession & Affirmed original & $\begin{array}{l}\text { Subscribed to an altered } \\
\text { version }\end{array}$ \\
\hline 18. National government & Germany: monarchical & Switzerland: republic \\
\hline 19. Assistant/successor & Philip Melanchthon & Theodore Beza \\
\hline 20. Melanchthon & Respected understudy & Beloved fellow scholar \\
\hline 21. Distinctive ministry & Prophetic preaching & Organized theology \\
\hline 22. Marriage & Married an ex-nun & $\begin{array}{l}\text { Married widowed } \\
\text { Anabaptist }\end{array}$ \\
\hline 23. Best-known work & $\begin{array}{l}\text { Translated Bible and } \\
\text { catechisms }\end{array}$ & $\begin{array}{l}\text { Institutes of the Christian } \\
\text { Religion }\end{array}$ \\
\hline 24. Family & Strong, healthy family & Children died in infancy \\
\hline 25. Intellectual method & Theology-philosophy & $\begin{array}{l}\text { Humanistic-legal } \\
\text { training }\end{array}$ \\
\hline 26. Hermeneutic & Law/gospel distinction & $\begin{array}{l}\text { Unity/diversity of } \\
\text { covenant }\end{array}$ \\
\hline 27. Theological emphasis & Stressed justification & $\begin{array}{l}\text { Stressed biblical } \\
\text { theology }\end{array}$ \\
\hline $\begin{array}{l}\text { 28. Justification } \\
\text { teaching }\end{array}$ & $\begin{array}{l}\text { Justification by faith } \\
\text { alone }\end{array}$ & Justification in covenant \\
\hline 29. Predestination & $\begin{array}{l}\text { Affirmed but not } \\
\text { primary }\end{array}$ & Integral to his theology \\
\hline 30. Lord's Supper theory & Consubstantiation & Spiritual presence \\
\hline 31. Ecumenical spirit & Narrow theologically & $\begin{array}{l}\text { Reformed but } \\
\text { ecumenical }\end{array}$ \\
\hline $\begin{array}{l}\text { 32. Relationship to } \\
\text { Zurich }\end{array}$ & Refused fellowship & Established consensus \\
\hline 33. Liturgical freedom & Normative principle & Regulative principle \\
\hline 34. Denominationalism & Church named for him & $\begin{array}{l}\text { No church named for } \\
\text { him }\end{array}$ \\
\hline 35. Ecclesiology & Bishop/episcopal & Elder/presbyterian \\
\hline 36. Church discipline & Left to magistrate & $\begin{array}{l}\text { Duty of elders/ } \\
\text { consistory }\end{array}$ \\
\hline 37. Burial & Grave in church known & Grave site unknown \\
\hline 38. Theological tradition & Lutheranism & Reformed/Presbyterian \\
\hline 39. Theological students & Called Lutherans & Called Calvinists \\
\hline $\begin{array}{l}\text { 40. Growth and mission } \\
\text { work }\end{array}$ & Global & Global \\
\hline
\end{tabular}


Luther's and Calvin's Reformation teachings embraced the theological commitments of the historic ancient church. The theologies of both Luther ${ }^{8}$ and Calvin ${ }^{9}$ as evidenced by their creeds were emphatically

- monotheistic: there is only one God, in accordance with Judaism;

- theistic: God is personally involved in the world through creation, revelation, incarnation, and providence;

- Trinitarian: although God is one, he subsists in three distinct persons in agreement with the Council of Nicea, 325;

- christologically orthodox: the Lord Jesus Christ as Savior is one person, fully God and fully man, as held by the creeds of the ecumenical councils; and

- Augustinian: Adam's fall impacted all mankind so that all are in need of God's grace for salvation from sin and death through faith in Christ.

Moreover, specific foundational theological concepts, known as the mottos of the Reformation, form the core of the Protestantism confessed by Luther and Calvin. Five primary slogans, developed after the Reformation, summarize the theological commitments of the Protestant Reformations led by Luther and Calvin: sola Scriptura, sola fide, sola gratia, solus Christus, and soli Deo gloria. ${ }^{10} \mathrm{~A}$ sixth basic Reformation principle may be added: the priesthood of the believer. ${ }^{11}$

8 See articles I-III, XVIII-XIX in the 1530 Lutheran Augsburg Confession written by Philip Melanchthon, which not only defended Luther's teaching, but was also greatly praised by Luther; Robert Kolb and Timothy J. Wengert, eds., The Book of Concord (Minneapolis: Fortress, 2000), 36-39, 50-53. Calvin too during his early ministry had subscribed to the Augsburg Confession. See Peter A. Lillback, "Calvin's Final Verdict on the Augsburg Confession," in Aspects of Reforming: Theology and Practice in Sixteenth Century Europe, ed. Michael Parsons (Milton Keynes: Paternoster, 2013), 98-117.

9 See articles I-II, VII-XII in the Gallican or French Confession written by Calvin and others, http://www.creeds.net/reformed/frconf.htm. Cf. also articles I, III, VIII, IX-XV in the Reformed and Calvinistic Belgic Confession, see Philip Schaff, ed. The Creeds of Christendom (Grand Rapids: Baker, 1983), 3:359-60, 363-67, 383-85, 390-96.

${ }^{10}$ For more detail, see in this issue, Garry J. Williams, "The Five Solas of the Reformation: Then and Now." See also the Five Solas Series edited by Matthew Barrett published by Crossway. A book has been written for each of the "solas" for the 2017 Reformation anniversary year. See also Carl R. Trueman, Luther's Legacy: Salvation and English Reformers, 1525-1556 (Oxford: Clarendon, 2002).

${ }^{11}$ For a brief treatment and application of this principle to the contemporary African church, see in this issue, Conrad Mbewe, "The Priesthood of All Believers in Africa." 


\section{Interpretations of the Protestant Reformation: Why Was There a Reformation?}

Given the Reformation's continuity with early Christian theology, why was there a Reformation? Was the Reformation necessary? To answer these questions, various interpretations of the Reformation have been offered. ${ }^{12}$ Many Protestants in the Reformed tradition follow Merle d'Aubigné's perspective developed in his nineteenth-century History of the Reformation in the Sixteenth Century. D'Aubigné saw the Reformation as the providential blessing of God's action in history, ${ }^{13}$ declaring, "History must live by that principle of life which is proper to it, and that life is God. He must be acknowledged and proclaimed in history; - and the course of events must be displayed as the annals of the government of a Supreme Disposer."14

Early Roman Catholic interpretations of the Reformation, however, took an opposite perspective. Seeking to refute d'Aubigné, American Catholic Bishop Martin John Spalding wrote D'Aubignés History of the Great Reformation in Germany and Switzerland, ${ }^{15}$ in which he claimed against d'Aubigné that Luther's Reformation was a rebellion against the true church and influenced by the devil. ${ }^{16}$ Émile G. Léonard rejoined,

Adopting the traditional position of the anti-Protestant polemists, M. Maritain can still write, on the subject of Luther: "This, if I may say so, is no more than the classic story of the fallen monk." But the Protestants long maintained, and still do occasionally, that the Reformation was a reaction against the licentiousness of the priests and the debaucheries of the Papacy; they are confirmed in this view by a late writing in which Luther claims that his revolt arose from his horrified discovery of the shameful practices of Rome, during his visit to Italy. ${ }^{17}$

12 See W. Stanford Reid, The Reformation: Revival or Revolution? (New York: Holt, Rinehart \& Winston, 1968); Lewis W. Spitz, ed., The Reformation: Basic Interpretations (Lexington, MA: Heath \& Company, 1972).

${ }^{13}$ For example, "Thus the English Reformation began independently of those of Luther and Zwingle- deriving its origin from God alone." Jean Henri Merle d'Aubigné, History of the Great Reformation of the Sixteenth Century (New York: American Tract Society, 1846), 1:150, http://www.gutenberg.org/files/41484/41484-h/41484-h.htm.

${ }^{14}$ Ibid., 1 :v.

${ }^{15} \mathrm{He}$ concludes, "We have now completed our task.... We have examined the principal false statements of M. D’Aubigné. ... To have unmasked his hypocrisy and laid bare his contradictions, would have imposed on us an almost endless labor." Martin John Spalding, D'Aubigné's Great Reformation in Germany and Switzerland, Reviewed and Refuted, 2nd ed. (Dublin: Battersby, 1846), 358; online: https://books.google.com/books?id=dKFdAAAAcAAJ\&printsec= frontcover $\# \mathrm{v}=$ onepage $\& \mathrm{q} \& \mathrm{f}=$ false.

${ }^{16}$ Among the forty plus references connecting Luther with the devil, we find, " $\mathrm{He}$ is puffed up,' says another, 'with pride and arrogance, and is seduced by Satan." Ibid., 45.

${ }^{17}$ Émile G. Léonard, "Revival of the Church's Life," in Reid, The Reformation: Revival or Revolution?, 14. 
Hugh Ross Williamson, a twentieth-century convert to Catholicism from a nonconformist background, asserted in The Beginnings of the English Reformation that the English Reformation was motivated by the nobility's greed and quest to confiscate the Church's lands. ${ }^{18}$ While recognizing the covetousness of the lords of old England, Henri Hauser answers this charge by rejecting its reductionist explanation: "The Reformation of the sixteenth century has the dual character of a social revolution and a religious revolution." 19 Neither economics nor spiritual issues alone can fully account for all that happened in the political and ecclesiastical arenas of the Reformation era.

After the mid-twentieth century, post-Vatican II Catholic interpretations have generally been less antagonistic. George H. Tavard insisted that there are points of similarity between Reformation doctrine and Catholic beliefs: "If these precautions are adopted, it will then be seen how much closer is the profound spirituality of the Protestant mind to Catholicism than it believes itself to be." ${ }^{20}$ Pierre Janelle focused on the Catholic Reformation, arguing that a reformation was needed due to "the disease of anarchy" that afflicted the Church. ${ }^{21}$ This new tone has been met by a friendlier Protestant approach represented, for example, by Léonard. In his $A$ History of Protestantism, he interpreted the Reformation in terms of continuity with the historic Catholic faith rather than as a revolt, considering the Reformation the full flowering of the Catholic tradition. ${ }^{22}$

Twentieth-century Lutheran scholars such as Gerhard Ritter and Ernest George Schwiebert have interpreted the Reformation in light of Luther's Germanic spirit and emphasized the German context of the Reformation. ${ }^{23}$

${ }^{18}$ Hugh Ross Williamson, The Beginnings of the English Reformation (New York: Sheed \& Ward, 1957), 9-21.

${ }^{19}$ Cited in Léonard, "Revival of the Church's Life," 15.

${ }^{20}$ George H. Tavard, Protestantism (New York: Hawthorne, 1959) quoted in Reid, The Reformation: Revival or Revolution?, 79. See also Tavard, The Starting Point of Calvin's Theology (Grand Rapids: Eerdmans, 2000).

21 "According to early Protestant controversialists, such as Tyndale, the abuses in the Church were the consequence of false doctrine: errors in faith led to errors in conduct. A close study of fifteenth-century conditions brings us, however, to a wholly different conclusion. The abuses may be shown to have sprung, not from mistaken notions on justification, the worship of the saints, Purgatory, etc., but from the state of administrative anarchy which had prevailed since the Great Schism.” Pierre Janelle, The Catholic Reformation (Milwaukee: Bruce, 1949), 4-5. Online: https://archive.org/details/catholicreformat012266mbp.

22 "I must emphasise at the outset - for it is one of the basic principles and guiding themes of this book - that the Reformation, far more than a revolt against Catholic faith, was its culmination and its full flowering." Léonard, "Revival of the Church's Life," 16. Cf. Émile G. Léonard, Histoire générale du protestantisme (Paris: Presses Universitaires de France, 1961), 1:10.

${ }^{23}$ Cf. Arthur C. McGiffert, Martin Luther: The Man and His Work (New York: Century, 1912), 166; online: https://archive.org/details/martinluthermanh00mcgirich; and Ernest 
Yet Léonard has reasoned,

Luther appeared in Germany; but three years after the Theses there were "Lutherans" all over Europe. When a problem of vital importance concerns a whole world, and it adopts, from the first and everywhere at once, the solution found in a particular place, this place itself is of little account. ${ }^{24}$

Moreover, George H. Williams, in his Radical Reformation, demonstrated the theological expanse of the Reformation beyond Luther and Calvin by highlighting the important impact of even more radical Reformers. He documented that "radical reformers" rejected the role of the state in the reforming of the church, thus by contrast making the Lutheran, Anglican, and Reformed "magisterial reformers." 25

Secular interpreters have identified other causes for the Reformation. Preserved Smith has pointed to science and ethical feeling. ${ }^{26}$ Eva Priester has interpreted the Reformation in socioeconomic terms along Marxist lines. ${ }^{27}$ H. A. E. Van Gelder has claimed that the Renaissance was the true Reformation. ${ }^{28}$ Roland Bainton has offered a multifaceted approach, developing the varied issues of morals, doctrine, economics and politics. ${ }^{29}$

\section{Indulgences and Other Abuses Evoked Concerns for Reform}

Regardless of the interpretation one holds regarding the Reformation, early Protestants saw themselves as reformers. ${ }^{30}$ Protestants criticized Rome due to the endemic abuses they observed and experienced in medieval Christendom. Best known, given its role in Luther's Reformation, was the

George Schwiebert, Luther and His Times: The Reformation from a New Perspective (St. Louis: Concordia, 1950).

${ }^{24}$ Léonard, "Revival of the Church's Life," 13.

${ }^{25}$ George H. Williams, The Radical Reformation (Philadelphia:Westminster, 1962).

${ }^{26}$ Preserved Smith, The Age of the Reformation (New York: Holt, Rinehart \& Winston, 1948), $743-50$

${ }^{27}$ Eva Priester, Kurze Geschichte Österreichs (Vienna: Globus, 1946), 111-19. Cf. translation by C. J. Munford and W. Stanford Reid in Reid, The Reformation: Revival or Revolution?, $98-105$.

${ }^{28}$ H. A. E. Van Gelder, The Two Reformations of the 16th Century (The Hague: Nijhoff, 1961), 3-10.

${ }^{29}$ Roland H. Bainton, Here I Stand: A Life of Martin Luther (Nashville: Abingdon, 1950).

${ }^{30}$ For surveys of the Reformation, see Roland H. Bainton, The Reformation of the Sixteenth Century (Boston: Beacon, 1956); Hans J. Hillerbrand, ed., The Reformation: A Narrative History Related by Contemporary Observers and Participants (Grand Rapids: Baker, 1978); Lewis W. Spitz, The Renaissance and Reformation Movements (Chicago: McNally, 1971); The Protestant Reformation, 1517-1559 (New York: Harper \& Row, 1985); Heiko A. Oberman, The Dawn of the Reformation (Grand Rapids: Eerdmans, 1992). 
sale of indulgences emerging from the sacrament of penance. Forerunners of the Reformation had identified indulgences as an abuse that needed to be reformed. ${ }^{31}$

Concern to correct the church's abuses is seen in the first Protestant creed that appeared in 1530, thirteen years after Luther's Ninety-Five Theses. The Augsburg Confession addressed seven abuses that had been remedied by 1530 in the churches adhering to Luther's Reformation, namely, both elements of the Sacrament, the marriage of priests, the Mass, confession, the distinction of meats, monastic vows, and ecclesiastical power. ${ }^{32}$ Surprisingly, the issue of indulgences was not addressed, although it was mentioned in the conclusion. The conclusion also stated that along with the enumerated abuses, others remained, some of which were identified but left without critique. ${ }^{33}$ Thus medieval Christianity was permeated with practices tolerated by the church that could not be warranted by Scripture alone.

There was a direct link between penance and indulgences. ${ }^{34}$ In the sacrament of penance, forgiveness of sins was thought to be secured in part by acts of self-denial such as pilgrimages to shrines or the veneration of relics. When such acts of penance became inconvenient, a monetary payment was accepted in lieu of the performance of the spiritual actions specified by the priest.

Indulgences grew out of the third and final aspect of penance. The three steps of the sacrament of penance in Roman Catholic theology are contrition, confession and absolution, and satisfaction. When the sinner felt sorrow for $\sin$ (contrition) and was moved to confess the sin to the priest, he could be forgiven or absolved of his sin by the priest. But to be sure that the confession was sincere and to make up for the sinner's wrongdoing, something specific needed to be done. This then was the act of penance, providing satisfaction for the sin.

In those circumstances when the sinner could not effectively offer satisfaction for his $\sin$ by the mandated penance, a substitute act was needed. In such cases, purchasing an indulgence was deemed appropriate. Indulgences were aptly named, as the church was "indulging" the penitent by providing

${ }^{31}$ See Peter A. Lillback, "Forerunners of the Reformation," in Unio cum Christo 1.1-2 (Fall 2016): 77-101.

${ }^{32}$ See the Augsburg Confession, articles XXII-XXVIII. The heading to these articles explains the early Reformation efforts to correct the abuses of the medieval church: "The churches among us do not dissent from the catholic church in any article of the faith but only set aside a few abuses that are new and were accepted because of corruption over time." See Kolb and Wengert, Book of Concord, 60-105, esp. 61.

33 "Although more abuses could be mentioned, we have included only the principal ones to avoid prolixity." Ibid., 105.

${ }^{34}$ See Thomas Schirrmacher, Indulgences: A History of Theology and Reality of Indulgences and Purgatory: A Protestant Evaluation, 2nd ed. (Bonn:Verlag für Kultur und Wissenschaft, 2012). 
help that it was not required to offer. The theological basis for indulgences was the treasury of merit. The church claimed that the saints had done so much good that they had done even more than they needed for themselves. These works above and beyond the call of duty - works of supererogationby the saints, Mary, and Christ were retained by the church and could be administered to others through the sale of indulgences.

The practice proved lucrative and was gradually expanded, reaching to even future sins through plenary indulgences. The Crusades, for example, were advanced by the promise of a plenary indulgence for participation by Pope Boniface VIII in the Jubilee year of 1300. Eventually, the purchase of indulgences benefited not only the living but also deceased sinners by shortening their suffering in purgatory. Thus indulgences helped raise troops for the Crusades, and their revenues supported the building of papal edifices.

Given the wealth and power vested in the papacy along with the lack of accountability, various forms of corruption developed. The exercise of untethered papal power manifested itself via the interdict, which forbade the celebration of the sacraments in a given locale based on the claim that the pontiff had the power to remove the priests' ability to distribute sacramental grace if he so determined. ${ }^{35}$ This threat weighed heavily on Roman Catholic civil authorities when they contemplated challenging papal power or prerogatives. Due to the power and wealth associated with the bishop's office, simony, or the sale of church offices, was a temptation and a regular practice of the medieval hierarchy. ${ }^{36}$

Superstitions became widespread due to vast illiteracy and the absence of the Bible in the languages of the people, exacerbated by the carnage of the plague. ${ }^{37}$ The preeminence of the priest was enhanced by teaching the spiritual inferiority of family life in comparison to celibacy. The elevation of the monastic ideals of obedience, chastity, and poverty added to social instability. The social fabric was stretched beyond biblical values as mandatory celibacy was ameliorated by a general acceptance of priests having concubines. The vow of poverty resulted in the glorification of begging, while the mandate of obedience to monastic authorities became tantamount to blind faith.

The issue of authority for the medieval church became problematic due to the recognition of three conflicting sources of authority in Roman Catholicism: the pope, tradition, and the Bible. It was not clear which was the

${ }^{35}$ Cf. Williston Walker, A History of the Christian Church (New York: Scribner's Sons, 1970), 208-10.

${ }^{36}$ Cf. Spitz, The Renaissance and Reformation Movements, 54.

${ }^{37}$ See Peter A. Lillback, "Into the Mystic," in Table Talk (July 2014): 24-27; "Forerunners of the Reformation," 77-84. 
ultimate authority in controversies. Moreover, there was an inherent struggle between the relationship of nature and grace. Did man save himself partly by merit? ${ }^{38}$ Was Christ's saving work sufficient, or must human effort and the merits of the saints assist in man's salvation? Could man discover spiritual truth by reason without divine revelation, as claimed by Thomas Aquinas's integration of Aristotle's philosophy with semi-Augustinian theology?

International crises helped prepare the way for the Reformation. In the preceding century, various church councils dealt with schisms that arose when three popes simultaneously claimed legitimate authority. ${ }^{39}$ The Council of Constance was called to restore order. European nationalism emerged as the church levied the crusades against Muslim-controlled holy sites and to resist Islamic invasions in the East. The discovery of the New World and scientific investigation also created intellectual challenges, as long-held faith positions were challenged by empirical research.

The popes compelled uniformity through the Inquisition. The Holy Office addressed perceived heresies - such as the views of forerunners and Protestants like Luther and Calvin-by church-sanctioned persecution and torture. Ultimately, Rome's unwillingness to reform from within compelled magistrates to seek reformation from without.

\section{Luther's Critique of Indulgences Led to the Break with Rome and the Beginnings of Lutheran Theology}

The times and the man met in Luther. ${ }^{40}$ His Ninety-Five Theses unleashed a firestorm that ultimately gave rise to the Protestant faith. ${ }^{41}$ The sale of

${ }^{38}$ See Peter A. Lillback, The Binding of God: Calvin's Role in the Development of Covenant Theology (Grand Rapids: Baker, 2001), 45-57; "Theological Light from the Medieval Era? Anselm and the Logic of the Atonement," in The Practical Calvinist: An Introduction to the Presbyterian and Reformed Heritage. In Honor of Dr. D. Clair Davis, ed. Peter A. Lillback (Fearn, Ross-shire: Christian Focus, 2002), 69-93; Heiko Oberman, The Harvest of Medieval Theology: Gabriel Biel and Late Medieval Nomalism (Cambridge: Harvard University Press, 1963).

${ }^{39}$ See Peter A. Lillback, "The Relationship of Church and State," in Reformation Theology, ed. Matthew Barrett (Wheaton, IL: Crossway, 2017), 500-538.

${ }^{40}$ Important sources on Luther include: Mark U. Edwards Jr., Luther's Last Battles: Politics and Polemics, 1531-1546 (Ithaca: Cornell University Press, 1983); Timothy George, Theology of the Reformers (Nashville: Broadman \& Holman, 1988); Alister E. McGrath, The Intellectual Origins of the European Reformation (Oxford: Blackwell, 1987); Steven Ozment, The Age of Reform, 1250-1550: An Intellectual and Religious History of Late Medieval and Reformation Europe (New Haven: Yale University Press, 1980); Jaroslav Pelikan, The Christian Tradition: A History of the Development of Doctrine, vol. 4: Reformation of Church and Dogma, 1300-1700 (Chicago: University of Chicago Press, 1984); Gordon Rupp, Patterns of Reformation (Philadelphia: Fortress, 1969).

${ }^{41}$ For a text of Luther's famous Ninety-Five Theses, see Martin Luther, "The 95 Theses," Center for Reformed Theology and Apologetics, http://www.reformed.org/documents/index. 
indulgences in Germany was authorized by Pope Leo X and Albrecht of Brandenburg to build Saint Peter's. Johann Tetzel, a German Dominican friar, who held the positions of Grand Inquisitor of Heresy in Poland and Grand Commissioner for Indulgences in Germany, was authorized to sell indulgences in Wittenberg, where Luther ministered. Luther's concern over the deleterious impact of indulgences on the morality of the people led him to compose his theses. He posted his critique on October 31, 1517. The theses gained great interest among humanist scholars. They were soon published and disseminated, creating controversy and financial furor in Rome.

Their themes can be illustrated by a few examples. Theses 1-2 undercut the alleged scriptural basis for indulgences:

1. When our Lord and Master Jesus Christ said, "Repent," he willed the entire life of believers to be one of repentance.

2. This word cannot be understood as referring to the sacrament of penance, that is, confession and satisfaction, as administered by the clergy.

Thesis 5 declared that the pope's power with respect to indulgences was limited. Theses 7, 71, and 91 revealed that Luther thought of himself as a Catholic and was not completely opposed to indulgences. Theses 11 and 13 questioned the effect of indulgences on those in purgatory. Several theses aimed at correcting abuses fostered by Tetzel $(21,27,28,35,75,77$, and 79) and clarifying what Christians should be taught about them (42-51). Luther raised searching questions that were difficult to answer (81-90):

82. Such as: "Why does not the pope empty purgatory for the sake of holy love and the dire need of the souls that are there if he redeems an infinite number of souls for the sake of miserable money with which to build a church? The former reason would be most just; the latter is most trivial.

86. Again: "Why does not the pope, whose wealth is today greater than the wealth of the richest Crassus, build this one basilica of St. Peter with his own money rather than with the money of poor believers?

In 1519 Luther debated his developing theology with John Eck at Leipzig, where Luther was compelled to identify some of his views with those of John Hus, who had been burned at the stake as a heretic by the Council of Constance a century earlier. He then received Pope Leo X's bull of

html?mainframe=http://www.reformed.org/documents/95_theses.html and Timothy J.Wengert, Martin Luther's Ninety-Five Theses:With Introduction, Commentary and Study Guide (Philadelphia: Fortress, 2015). 
excommunication, Exsurge Domine, dated June 15, 1520. He was given sixty days to recant upon the publication of the bull in Saxony or else be excommunicated. Luther received it in October 1520, and sixty days later, on December 10, 1520, he publically burned it. Luther's condemnation of the bull was decisive:

Whoever wrote this bull, he is Antichrist. I protest before God, our Lord Jesus, his sacred angels, and the whole world that with my whole heart I dissent from the damnation of this bull, that I curse and execrate it as sacrilege and blasphemy of Christ, God's Son and our Lord. This be my recantation, $\mathrm{O}$ bull, thou daughter of bulls. ${ }^{42}$

Luther was excommunicated on January 3,1521. His fate was now in the hands of Emperor Charles V.

He arrived in Worms on April 16, cheered and welcomed by the people, and was summoned to the Imperial Diet to appear before Charles V on April 18, 1521. He appeared before the emperor twice, and each time he was told to recant. Luther refused, since he saw no evidence his teachings were unbiblical. He famously declared,

Unless I am convicted by Scripture and plain reason-I do not accept the authority of popes and councils, for they have contradicted each other-my conscience is captive to the Word of God. I cannot and I will not recant anything, for to go against conscience is neither right nor safe. Here I stand, I cannot do otherwise. God help me, Amen. ${ }^{43}$

Some claim that the words "Here I stand, I cannot do otherwise" were not spoken by Luther, but scholars like Bainton argue that they could well be authentic. ${ }^{44}$

When dismissed, Luther was not arrested, because he had a letter of safe conduct guaranteeing three weeks' safe travel. He left for home on April 25. But when Luther and his protecting princes departed, the emperor imposed an Imperial Act declaring Luther an outlaw. Thus he could be slain by anyone without fear of reprisal. So Elector Friedrich the Wise had Luther kidnapped on May 4 to assure Luther's safety. Taken to the Wartburg Castle, Luther remained there for ten months. After only three months, he had translated the New Testament into German. Later he translated the Old Testament into German.

\footnotetext{
42 Bainton, Here I Stand, 155-56.

43 Ibid., 182.

44 The memorial statue of Luther in Worms bears the famous words.
} 
Foundational theological themes emerged in Luther's thought.$^{45}$ Rejecting the synergism of medieval covenant theology, he affirmed human spiritual inability in his classic treatise, the 1525 Bondage of the Will. Medieval theologians taught that "God will not deny grace to the ones who do what lies within them." ${ }^{46}$ Instead of the doctrine of doing one's best in order to merit grace, his theology focused on the cross. Luther distinguished the theology of the cross, theologia crucis, from the theology of glory, theologia gloriae. Luther's theology of the cross insisted that salvation was found entirely in the work of Christ. The theology of glory, however, was Rome's doctrine that a person in some measure could merit salvation. For Luther, if this were true, the glory of salvation was not exclusively in Christ and his cross, but shared with human good works. Luther insisted that the theology of glory had to be resisted, as it denied the work of Christ alone in salvation. This was essential for establishing his central doctrine of Christ's alien righteousness forgiving a sinner through faith, or, justification by faith alone.

Luther's view of the Christian is captured in the phrase simul justus et peccator, that is, believers in Christ are "simultaneously both righteous and sinful." They are sinful in themselves before God. But in Christ by faith, the believer though sinner is forgiven and declared righteous. Luther buttressed his understanding of the gospel by an interpretative method contrasting law and gospel: the law was God's demand of obedience, a law that none could keep and that reveals human sinfulness, but the gospel, the good news of salvation in Christ, manifests the forgiveness of sins. The gospel is Christ's work for sinners, not sinners' works for God. Indulgences were unacceptable because they put human effort (law) in place of the good news of Christ. ${ }^{47}$

For Luther, the church was the place of gospel proclamation and the administration of the two sacraments of baptism and the Lord's Supper and hence a vital expression of God's saving work. Luther's doctrine of the sacraments was central to the proclamation of the gospel. The preached word of Scripture was to be conjoined with the visible word of the sacraments. The church imparted the grace of God through the gospel and through the saving benefit of baptism and by reception of the body and blood of Christ

${ }^{45}$ Cf. Paul Althaus, The Theology of Martin Luther, trans. Robert C. Schultz (Philadelphia: Fortress, 1979); Gerhard Ebeling, Luther: An Introduction to His Thought (Philadelphia: Fortress, 1972); Werner Elert, The Structure of Lutheranism, trans. Walter A. Hansen (St. Louis: Concordia, 1962).

${ }^{46}$ Facientibus quod in se est Deus non denegat gratiam. Cf. Lillback, The Binding of God, $46-50$.

${ }^{47}$ Cf. ibid., 58-80. 
in the Lord's Supper. Luther's view of the Eucharist was not the Roman Catholic doctrine of transubstantiation, where the Eucharistic elements became the body and blood of Christ. Rather, he affirmed consubstantiation, wherein the bread and wine remained what they were, but with the consecration of the elements, the literal body and blood of Christ were "in, with, and under" the elements, and thus truly present to those who partake.

Luther never wanted a church named for him. He wished his church to be named the Evangelical Church, after the gospel. Eck first used the term Lutheran at the Leipzig debate (1519) in the way Catholics labeled heretical groups. Nowadays, churches in the tradition of Luther are positively termed Lutheran, often without the name Evangelical. ${ }^{48}$ The contributions of Luther are vast, but some best known are the Lutheran churches, Luther's catechisms, the German Bible, Luther's immense writings, a system of education, the centrality of preaching in worship, the elevation of Christian home life, including marriage for the clergy, Bible translations in the language of the people, critique of the papacy, the establishment of the Protestant work ethic resulting in the demise of the mendicant orders, and his hymns and his choral and instrumental liturgical music. Luther died in Eisleben, his birth town, on February 18, 1546. His last words were spoken in German and Latin, "We are beggars (German). This is true (Latin)." Lutheranism spread, becoming established in Denmark, Norway, Sweden, and Finland, while making significant impact in Scotland, England, Poland, and Holland.

\section{The Reformed Tradition of Calvin}

Luther's Reformation swept through Europe, aided by the printing press, interested scholars, and devout and self-interested nobility, as well as the threat of Islam, which prevented imperial forces from crushing the Lutheran movement. Other Reformers followed, who critiqued and perfected Luther's Reformation theology. Important names among these include the following:

- Philip Melanchthon and Martin Chemnitz, Luther's followers

- Ulrich Zwingli, Martin Bucer, and Heinrich Bullinger, who were German and Swiss German Reformed

- In reaction to the Zwinglian and Rhineland Reformers and the Lutheran Reformers, the more radical Anabaptists and Brethren Reformers emerged

48 “Lutheranism," Wikipedia, http://en.wikipedia.org/wiki/Lutheranism. Cf. Orlando O. Espin and James B. Nickoloff, eds., An Introductory Dictionary of Theology and Religious Studies (Collegeville, MN: Liturgical Press, 2007), 796. 
- John Calvin and Theodore Beza, who were Swiss and French Reformed

- Thomas Cranmer, Hugh Latimer, and Nicholas Ridley, fathers of the Anglican Reformation and the Puritan movement, from which in turn the Baptists emerged

- John Knox, father of Scottish Presbyterianism.

Calvin's reformation activities cannot be understood apart from those of Luther and Zwingli. ${ }^{49}$ Zwingli (1484-1531) was a scholarly priest who began ministry in Zurich in 1519. Among his theological contributions were the development of a covenantal hermeneutic, the defense of infant baptism from a covenantal perspective, and development of the memorial view of the Lord's Supper against the Roman Church's transubstantiation and Luther's consubstantiation theory. He was converted to the Reformation movement in 1519, facing the plague, reading Luther's writings, and studying Erasmus's newly published Greek New Testament (1516). His Reformation theology publically appeared in 1521 with his Sixty-Seven Articles. The Mass in Zurich was abolished in 1525. Zwingli and Luther split over the doctrine of the Lord's Supper in spite of the best efforts of Bucer to reconcile them..$^{50} \mathrm{Z}$ wingli died at the Second Battle of Cappel in 1531, fighting as a warrior chaplain against Roman Catholic Swiss cantons. Zwingli's theology tended to stress the social and covenantal dimensions of faith, while Luther's theology emphasized the individual's faith for justification. ${ }^{51}$

Heinrich Bullinger (1504-1575) succeeded Zwingli. After his university studies, Bullinger was persuaded of Zwingli's reforms. Taking up Zwingli's mantle, he proved to be a gifted leader whose ministry reached internationally through his voluminous letters. He contributed early to covenant theology, ${ }^{52}$ and his works included the Second Helvetic Confession and his sermons entitled the Decades, which greatly influenced the Reformation in England.

${ }^{49}$ Cf. Gregory J. Miller, "Huldrych Zwingli (1484-1531)," in The Reformation Theologians: An Introduction to Theology in the Early Modern Period, ed. Carter Lindberg (Malden, MA: Blackwell, 2002), 165.

${ }^{50}$ Cf. Hastings Eells, Martin Bucer (New York: Russell \& Russell, 1971). For a contemporary summary of the great debate between Luther and Zwingli at the Marburg Colloquy, see Hillerbrand, The Reformation: A Narrative History, 155-63.

${ }^{51}$ See Bernd Moeller, Imperial Cities and the Reformation, ed. and trans. H. C. Erik Midelfort and Mark U. Edwards Jr. (Philadelphia: Fortress, 1972), 90-103.

${ }^{52}$ For how the covenant concept of Bullinger impacted the Reformers, see Peter A. Lillback, "The Early Reformed Covenant Paradigm: Vermigli in the Context of Bullinger, Luther and Calvin," in Peter MartyrVermigli and the European Reformations, ed. Frank A. James III (Leiden: Brill, 2004), 70-96. 
The Reformation in Geneva was intimately connected with the work of John Calvin. ${ }^{53}$ Calvin's studies led to expertise in law and the classical languages celebrated by the humanists. His first book appeared in 1532, a commentary on Seneca's De Clementia. Around this time he was converted to the Lutheran perspective. ${ }^{54}$ Calvin planned to be a scholar and had received acclaim for his first edition of the Institutes, written in 1536. However, William Farel's dramatic plea for Calvin to assist him in his reforming work in Geneva, made during Calvin's stop in Geneva on a journey elsewhere, changed the course of his life. From 1536 to his death in 1564 Calvin was associated with the theological leadership of Geneva-except for a threeyear exile in Strasbourg during 1538-41. He had gotten on the wrong side of the newly reformed Genevan magistrates regarding who could participate in the Lord's Supper. After Calvin had been called back, Geneva became the center of Reformed worship and theology that greatly impacted Reformation theology..$^{55}$

Calvin preferred Luther's writings over Zwingli's. Comparing Luther to Zwingli, he wrote in 1539 , "If the two men are compared with each other, you yourself know how much Luther has the preference." ${ }^{\text {6 }}$ His identification of Luther with the gospel is seen in his 1551 comments on Isaiah 22:17, where he describes Thomas More's persecution of Reformed believers: "He had been a very great persecutor of the Lutherans, that is, of the godly." ${ }^{57} \mathrm{In}$ the same year, Calvin related to Bullinger that adherents of "Lutheran doctrines" in his beloved France were facing persecutions of all kinds. ${ }^{58}$

Nevertheless, Calvin was impacted by the Swiss in terms of his covenantal approach to Scripture, and he reached a consensus on the Lord's Supper

${ }^{53}$ For biographies of Calvin, see Irena Backus and Philip Benedict, eds., Calvin and His Influence, 1509-2009 (New York: Oxford University Press, 2011); William J. Bouwsma, fohn Calvin: A Sixteenth Century Portrait (New York: Oxford University Press, 1988); Alexandre Ganoczy, "Calvin's Life," in Donald K. McKim, ed., The Cambridge Companion to fohn Calvin (Cambridge: Cambridge University Press, 2004); Bruce Gordon, Calvin (New Haven: Yale University Press, 2009); Alister E. McGrath, A Life of fohn Calvin (Oxford: Blackwell, 1990); John T. McNeil, The History and Character of Calvinism (Oxford: Oxford University Press, 1954); T. H. L. Parker, fohn Calvin: A Biography (Philadelphia: Westminster, 1975); David C. Steinmetz, Calvin in Context (Oxford: Oxford University Press, 1995).

${ }^{54}$ See Bouwsma, fohn Calvin, 11.

${ }^{55}$ See J. Todd Billings and I. John Hesselink, eds., Calvin's Theology and Its Reception: Disputes, Developments, and New Possibilities (Louisville: Westminster John Knox, 2012).

${ }^{56}$ John Calvin, Tracts and Letters, 7 vols., ed. Henry Beveridge and Jules Bonnet (1844-1858; repr., Carlisle, PA: Banner of Truth Trust, 2009), February 28, 1539, 4:109.

57 The French has “'C'est à dire, des enfans de Dieu;'-'That is, of the children of God.”' John Calvin, Commentary on the Book of the Prophet Isaiah, trans. William Pringle (Grand Rapids: Baker, 1996), 2:131.

${ }^{58}$ Calvin, Tracts and Letters, 5:320. 
with Bullinger in 1549. ${ }^{59}$ In 1534, two years before Calvin's first edition of the Institutes, Bullinger developed Zwingli's view of the covenant in the first monograph ever written on the covenant, Of the One and Eternal Testament or Covenant of God. ${ }^{60}$ Within a year or two of Bullinger's work, Calvin wrote the preface to the Geneva Bible, which developed a covenant theology that paralleled some of the perspectives of Bullinger. ${ }^{61}$ Calvin developed covenantal themes in the Institutes. ${ }^{62}$

Among the many contributions of Calvin, his greatest and most lasting was his Institutes of the Christian Religion, first published in 1536 and continually edited and expanded until its final 1559 edition. The Institutes were intended to be a theological guidebook for reading the Bible, offering a logical summation of its main truths from the Reformation perspective, dealing in four books with God the Father, God the Son, and God the Holy Spirit, as well as the church and sacraments. Calvin interacted with the history of the Christian tradition in the context of the clash of Protestantism with medieval Catholicism.

Reformed and Presbyterian theology, in its earliest form, is found in Calvin's theology. ${ }^{63}$ The Institutes presents classic statements of biblical authority, the Trinity, creation and providence, the history of the covenant, ${ }^{64}$ the application of the Ten Commandments to the Christian life, Christology, the saving work of Christ and its application to the believer by union with

${ }^{59}$ For a discussion of the Consensus Tigurinus, see Schaff, Creeds of Christendom, 1:471-73.

${ }^{60}$ See Peter A. Lillback and Richard B. Gaffin, Jr., eds., Thy Word Is Still Truth: Essential Writings on the Doctrine of Scripture from the Reformation to Today (Phillipsburg: P\&R Publishing, 2013), 245-70.

${ }^{61}$ The French title is, "A Tous Amateurs de Iesus Christ et de son Evangile, Salut," translated in English as Christ the End of the Law, Being the Preface to the Geneva Bible of 1550; see Lillback and Gaffin, ThyWord Is Still Truth, 271-82.

${ }^{62}$ See Lillback, The Binding of God.

${ }^{63}$ Brian A. Gerrish, "The Place of Calvin in Christian Theology," in McKim, The Cambridge Companion to fohn Calvin, 289-304; W. Fred Graham, The Constructive Revolutionary: Fohn Calvin and His Socio-Economic Impact (Richmond, VA: John Knox, 1971); Paul Helm, fohn Calvin's Ideas (Oxford: Oxford University Press, 2004); I. John Hesselink, "Calvin's Theology," in McKim, The Cambridge Companion to fohn Calvin, 74-92; Anthony N. S. Lane, A Reader's Guide to Calvin's Institutes (Grand Rapids: Baker, 2009); Richard A. Muller, The Unaccommodated Calvin: Studies in the Foundation of a Theological Tradition (New York: Oxford University Press, 2001); Wilhelm Niesel, The Theology of Calvin (Grand Rapids: Baker, 1980); Scott M. Manetsch, Calvin's Company of Pastors: Pastoral Care and the Emerging Reformed Church, 15361609, Oxford Studies in Historical Theology (New York: Oxford University Press, 2013).

${ }^{64}$ See Peter A. Lillback, "Calvin's Interpretation of the History of Salvation:The Continuity and Discontinuity of the Covenant," in A Theological Guide to Calvin's Institutes: Essays and Analysis, ed. David W. Hall and Peter A. Lillback (Phillipsburg: P\&R Publishing, 2008), 168-204. 
Christ through the Holy Spirit, ${ }^{65}$ the church and sacraments (infant baptism and the Lord's Supper), ${ }^{66}$ and the relationship of church and state. ${ }^{67}$

The Institutes also presents "Calvinian" distinctives. While Calvin was a "Calvinist" teaching "double predestination," he did not treat predestination in the doctrine of God, but in Book Three, after his discussion of the work of Christ. Interestingly, he did not explicitly develop limited atonement, one of the traditional five points of Calvinism developed at the Synod of Dort (1618-1619). Calvin's doctrine of justification by faith alone supports Luther's justification by grace through faith, but Calvin developed justification within the covenant of grace as one of its dual blessings alongside sanctification. ${ }^{68}$

Calvin's theological approach differed significantly from Luther's, but generally not in an adversarial manner. These distinctions appear not only in his emphasis on the covenant ${ }^{69}$ and the covenantal context of justification, ${ }^{70}$ but also in his expression of other matters such as hermeneutics, ${ }^{71}$ the role of the law in the Christian's life, ${ }^{72}$ the Presbyterian form of church government, ${ }^{73}$ the relationship between church and state, ${ }^{74}$ how grace is administered

65 See Lillback, The Binding of God, 176-209.

66 See Peter A. Lillback, "Calvin's Covenantal Response to the Anabaptist View of Baptism," Biblical Horizons, http:/www.biblicalhorizons.com/miscellaneous/calvins-covenantal-responseto-the-anabaptist-view-of-baptism/.

67 See Lillback, "The Relationship of Church and State."

68 See Peter A. Lillback, "Calvin's Development of the Doctrine of Forensic Justification: Calvin and the Early Lutherans on the Relationship of Justification and Renewal," in Fustified in Christ: God's Plan for us in Fustification, ed. K. Scott Oliphint (Fearn, Ross-shire: Christian Focus, 2007), 51-80; Lillback, The Binding of God, 178-209.

69 Peter A. Lillback, "The Continuing Conundrum: Calvin and the Conditionality of the Covenant," Calvin Theological fournal 29.1 (1994): 42-74; "Ursinus' Development of the Covenant of Creation: A Debt to Melanchthon or Calvin?," Westminster Theological fournal 43 (1981): 247-88.

70 See Lillback, The Binding of God, 180-83.

71 See Peter A. Lillback, "All the Glorious Offices of Christ-1 Corinthians 1:29-31," in Preaching Like Calvin: Sermons from the 500th Anniversary Celebration, ed. David W. Hall (Phillipsburg: P\&R Publishing, 2010), 85-99; "Proclaiming Christ: An Apologetic for Redemptive Historical Preaching," in Westminster Conference in Korea (Philadelphia: Westminster, 2016), 9-43.

72 See Peter A. Lillback, "Indicative and Imperative: Calvin's Exposition of Deuteronomy 29:9-18 as an Example of Preaching the Covenant from an OT Context for the NT Church," in Westminster Conference in Korea (Philadelphia: Westminster, 2016), 76-107.

73 See Peter A. Lillback, "The Reformers' Rediscovery of Presbyterian Polity," in Pressing Toward the Mark: Essays Commemorating Fifty Years of the Orthodox Presbyterian Church, ed. Charles G. Dennison and Richard C. Gamble (Philadelphia:The Committee for the Historian of the Orthodox Presbyterian Church, 1986), 63-81; "Calvin's Primer on Presbyterianism," Christian Study Library, http://www.christianstudylibrary.org/files/pub/20110011\%20-\%20 Lillback\%20PA\%20-\%20Calvins\%20Primer\%20on\%20Presbyterianism.pdf.

74 See Lillback, "The Relationship of Church and State," 509-17. 
through baptism and how Christ is present in the Eucharist, ${ }^{75}$ and the significance and authority of the Augsburg Confession. ${ }^{76}$ Calvin's Reformed tradition spread from Switzerland into France, Germany, Hungary, Scotland, and the Netherlands.

\section{How Luther and Calvin Viewed Each Other}

Calvin and Luther never met. Luther knew only a little about Calvin but seemed favorably disposed to him. ${ }^{77}$ But Calvin was ever aware of Luther and had a range of opinions of the towering colossus on the Reformation terrain. For example, Calvin strove to limit the conflict between the Swiss Reformed and Luther that broke out over the Eucharist. Writing to Bullinger on November 25, 1544, he praised Luther's work, reminding Bullinger of Luther's extraordinary giftedness and the Reformed movement's indebtedness to him. ${ }^{78}$ However, the eventual failure to unite the Protestants, in Calvin's mind, was due to all sides, including Luther. ${ }^{79}$ In spite of the rupture, Calvin "was ready to pay him tribute. 'I have often said,' Calvin declared, 'that even though he were to call me a devil, I would nevertheless hold him in such honor that I would acknowledge him to be a distinguished servant of God."'\$0

Yet Calvin also struggled with the dominating and fiery temper of Luther. His criticism of Luther appeared in the ongoing sacramental controversy in 1544, marked by Luther's renewed disdain for the late Zwingli, who had died in 1531. Luther's stinging invective condemned the doctrines of the Zurich Reformer and his church, comparing them to the heresies of the radical Reformers. ${ }^{81}$ Deeply troubled and feeling Luther's wrath, even Melanchthon was distressed. Calvin wrote to Bucer on August 28, 1544,

I have written to you about our Pericles, who has again begun to thunder most vehemently on the subject of the Lord's Supper, and has written a fierce attack, in which you and I are beaten black and blue. I am a quiet peaceable bird, nor would be unwilling if I may depart out of this prison-house, if our disturber shall constrain me. ${ }^{82}$

75 See Lillback, The Binding of God, 242-63.

${ }^{76}$ See Peter A. Lillback, "Confessional Subscription Among the Sixteenth Century Reformers," in The Practice of Confessional Subscription, ed. David W. Hall (Lanham, MD: University Press of America, 1995), 33-66; "Calvin's Final Verdict on the Augsburg Confession."

77 See Calvin's November 20, 1539, letter to Farel, relating that Luther had spoken well of Calvin and his writings even though Calvin had been critical of Luther. In Calvin, Tracts and Letters, 4:166-67. Cf. Spitz, The Renaissance and Reformation Movements, 412-13.

${ }^{78}$ Calvin, Tracts and Letters, 4:432-34.

${ }^{79}$ Ibid., 4:89-90.

${ }^{80}$ Bouwsma, fohn Calvin, 18.

${ }^{81}$ See Lillback, The Binding of God, 76-80.

${ }^{82}$ Calvin, Tracts and Letters, 4:433. 
Calvin addressed Melanchthon about his "Pericles [who] allows himself to be carried beyond all due bounds with his love of thunder." Calvin argued that the church was at great risk if an individual possesses total authority: "In the Church we must always be upon our guard, lest we pay too great a deference to men. For it is all over with her, when a single individual, be he whosoever you please, has more authority than all the rest, especially where this very person does not scruple to try how far he may go." ${ }^{\prime 3}$ Similarly, Calvin wrote to Farel on October 10,1544, praising the patience of the brethren in Zurich while admitting "the rage of Luther," "Luther's unkindness," and "the danger ... from Luther." 84

Calvin attempted to limit the conflict by writing to Bullinger on November 25,1544 , about Luther's extraordinary giftedness and the Reformed movement's indebtedness to him. ${ }^{85}$ Under these difficult circumstances, Calvin highly appreciated Luther's work. ${ }^{86} \mathrm{He}$ did not, however, ignore Luther's "evil qualities" that "beset him." Moreover, he referred to his "violence" and "fierce invective," with which he had "harassed" the Reformed, revealing his "serious faults" and "vehemence of natural temperament." Calvin wished Luther were "more observant and careful in the acknowledgment of his own vices" instead of being so "prone to be over-indulgent to himself." William Bouwsma well summarizes Calvin's assessment of Luther:

Calvin wrote to Bucer in 1538, although he was "perfectly convinced of Luther's piety," he was repelled by his "craving for victory," his "haughty manner and abusive language," his "ignorance and most gross delusions," his "insolent fury," the same failings that had repelled Erasmus. Calvin was also critical of Luther's scholarship. He thought him, as an expositor, careless about "propriety of expression or historical context" and satisfied-for Calvin this was not enough - when he could "draw out fruitful doctrine." Like Zwingli, Calvin did not consider Luther the only early Reformer; he was "not the only one in the church of God to be looked up to." 88

But for all this, in Calvin's mind, Luther was one of God's "good men." Luther's death illustrated how "God takes good men out of this world, when he intends to punish ... the ungodly," adding, "In our own times a remarkable instance of this was given in the death of Luther, who was snatched from the world a short time before that terrible calamity befell Germany." 89

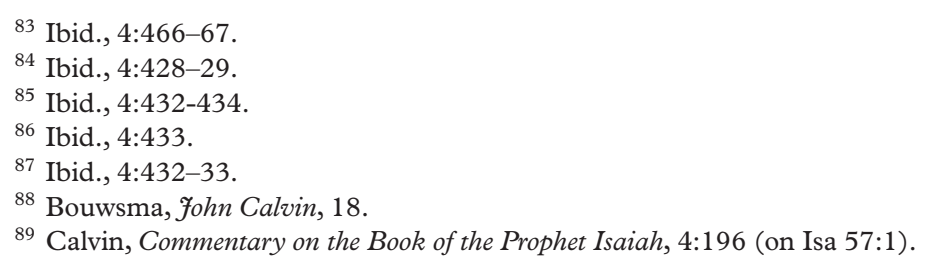


Thus Calvin, indebted to Luther, praised, defended, and criticized him. Calvin's essential assessment of the great Reformer was that Luther had launched a movement - a "miraculous" one to be sure-but one that nevertheless had to be advanced and perfected by others. Calvin mused in his 1550 Concerning Scandals,

We remember with amazement how deep was the abyss of ignorance and how horrible the darkness of the papacy. It was a great miracle of God that Luther and those who worked with him at the beginning in restoring the pure truth were able to emerge from it little by little. Some claim to be scandalized because these good personages did not see everything at once and did not finish and polish such a difficult work. It is as though they were accusing us of not seeing the sun shine as fully at dawn as at midday. ${ }^{90}$

\section{Twenty Lasting Consequences of Luther's and Calvin's Protestant Reformations}

The Reformation changed the medieval world and left a vast and permanent impact that is readily visible even today. Some of the most important are these:

1. The Protestant faith, with its distinctive doctrines, liturgies, hymnody, and psalm singing ${ }^{91}$

2. Bible translations in the languages of the people

3. The elevation of the vernacular languages into scholarly languages by the translation of the Bible, resulting in the decline of Latin

4. Universal education to promote the reading of the Bible, and the establishment of schools from childhood to university level ${ }^{92}$

5. The growth of printing, with the publication of Bibles and theological books, creating libraries, a literate clergy, and Bible-reading congregations

6. Marriage of the clergy, putting an end to monastic communities in Protestant lands, and elevating the spiritual value of the family for the church 83.

${ }^{90}$ John Calvin, Concerning Scandals, trans. JohnW. Fraser (Grand Rapids: Eerdmans, 1978),

${ }^{91}$ See Peter A. Lillback, "Our Songs in God's Worship," Christian Study Library, http:// www.christianstudylibrary.org/files/pub/20100168\%20-\%20Lillback\%20A\%20-\%20Our\% 20Songs $\% 20$ in $\% 20$ Gods\%20Worship.pdf.

${ }^{92}$ See Peter A. Lillback, "The Reformation and Education," in Table Talk (October 2016): $30-31$. 
7. The development of the nation state with a national church and the principle that the subject follows the faith of the ruler

8. The end of the hegemony of medieval Catholicism due to the birth of nations and state churches

9. Protestant confessions of faith and the birth of denominations due to confessional differences ${ }^{93}$

10. Liberty of conscience, the first step to political liberty and religious liberty, which gradually developed from the wars of religion as various confessional churches and minorities struggled with the established faith ${ }^{94}$

11. Development of an Erastian view of church and state, whereby the state was over the church, as among European Lutherans and Anglicans and in Zwingli's Zurich

12. Development of a sphere sovereignty view of church and state under Calvin, wherein each possessed a measure of independence from the other in matters that pertained to each ${ }^{95}$

13. Exploration and colonization of the New World advanced by persecuted minorities seeking religious freedom and by the sending out of missionaries with Reformation commitments

14. The interplay between republican and federal ideas of constitutional government, shaped by federal or covenantal theology ${ }^{96}$

15. The curtailment of monarchical power due to the rise of republican ideas of government, especially in regions impacted by Calvinism and covenant theology

16. Theories of political resistance developed by minorities who found the necessity of defending themselves from persecution and defending their consciences before governmental authorities ${ }^{97}$

17. Investigation in the humanities and development of the fields of empirical scientific exploration, encouraged by the Reformation's commitment to education

${ }^{93}$ See Schaff, Creeds of Christendom, vols. 1, 3 .

${ }^{94}$ See Peter A. Lillback, "From America to the World: Protestant Christianity's Creation of Religious Liberty," in Societas Dei: Furnal Agama Dan Masyarakat 2.1 (April 2015): 8-94; "The Huguenots'Via Dolorosa:The Life Under the Cross of the Persecuted Protestants of France," in God's Fiery Challenger for Our Time: Festschrift in Honor of Stephen Tong, ed. Benyamin F. Intan (Jakarta: Reformed Center for Religion and Society, 2007), 215-32.

${ }^{95}$ See Lillback, "The Relationship of Church and State," 510, 533.

${ }^{96}$ See Charles S. McCoy and J. Wayne Baker, Fountainhead of Federalism (Louisville: Westminster John Knox, 1991).

${ }^{97}$ See Lillback, "The Relationship of Church and State," $517 \mathrm{ff}$. 
18. The Protestant work ethic and the idea of a godly "secular" vocation, issuing in capitalism and the rise of an educated middle class, and in turn the growth of capital and business development, as well as banking and financial markets in Protestant lands ${ }^{98}$

19. World-affirming art and aesthetics, resulting from the doctrine of the goodness of creation and the questioning of the spiritual value of asceticism ${ }^{99}$

20. The division of Europe into Catholic, Lutheran, and Reformed regions, divisions still culturally evident, due to the conclusion of the Reformation era by the Religious Peace of Westphalia after the Thirty Years War.

Whether one agrees or not with Luther's and Calvin's Protestant Reformations, their labors have an abiding legacy. For those who agree, the Reformation was necessary and is relevant today. The Word of God, the glory of Christ in the gospel, and a life of faith in the power of the Holy Spirit's grace are as essential today as they were in the sixteenth century of Luther and Calvin.

${ }^{98}$ See Michael Wykes, "Devaluing the Scholastics: Calvin's Ethics of Usury," in Business Ethics Today, ed. Philip J. Clements (Philadelphia: Westminster Seminary Press, 2011), 95-125.

${ }^{99}$ See Laurel Gasque, Art and the Christian Mind: The Life and Work of H. R. Rookmaaker (Wheaton, IL: Crossway, 2005); H. R. Rookmaaker, Modern Art and the Death of a Culture (Wheaton, IL: Crossway, 1994). 



\title{
Luther and the Spanish Reformers
}

\section{FRANCES LUTTIKHUIZEN}

\begin{abstract}
Few of the Spanish Reformers actually met Luther or the other Reformers in person. However, despite the drastic measures taken by the Spanish authorities to keep "Lutheran" literature from entering Spain, the Spanish Reformers were well versed in Luther's writings. Prohibition engendered curiosity and curiosity a desire to learn more, which eventually led to acceptance of the Reformed faith, and in many cases martyrdom. This essay centers on early reactions to Luther and his message, the efforts of the Spanish ecclesiastical authorities to ban heretical literature, and the personal experiences of three men who had encounters with the northern Reformers: Francisco de Enzinas, Augustin de Cazalla, and Constantino de la Fuente.
\end{abstract}

\section{Introduction}

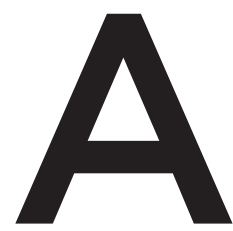

lthough there is evidence that Luther's writings had already entered Spain via Antwerp by $1519,{ }^{1}$ news of Luther himself as a person first arrived simply in the form of reports of a German friar proposing reforms in the church. A large segment of the population was ready for reforms, and they

1 This is evidenced from a letter dated February 14, 1519, written from Basel by Johannes Froben to Luther, in which he informed him that "Blasius Salmonius, a bookseller of Leipzig, presented me with certain treatises composed by you that he bought at the last Frankfort fair, 
welcomed such initiatives. Nevertheless, in the words of John Longhurst, "Although there was some momentary confusion as to who Luther was and what he represented, it was clear enough by 1521 that he was a revolutionary."2

\section{Early Testimonies}

Alfonso de Valdés, one of the emperor's secretaries, expressed alarm at the boldness with which the Reformer attacked papal authority. Also among the Spaniards belonging to the emperor's retinue present at Worms in 1521 were men closely associated with Cardinal Cisneros. One was a Franciscan friar, Francisco de Angelis Quiñones, member of the strict observant branch of the Order of Friars Minor and as such open to reforms. Quiñones was impressed with Luther's message, and on his way back to Spain to assist in subduing the friars involved in the Comuneros Revolt, which had broken out in Castile, ${ }^{3}$ he stopped at Basel, where he had a long discussion with a fellow "observant," the renowned Hebraist Conrad Pellican, who at that time was divinity lecturer and superior at the Franciscan Minorite convent at Ruffach, France. ${ }^{4}$ Pellican was already sympathetic towards Luther, and shortly afterwards he would renounce his monk's habit and embrace Luther's teachings. Quiñones, on the other hand, though he may have had his doubts and did have sporadic contact with the alumbrados ${ }^{5}$ once he returned to Spain, and as General of the Order from 1523 to 1527 radically opposed and suppressed the practices of the "apocalyptic" recogidos, ${ }^{6}$ never yielded.

which being approved by learned men, I immediately put to press, and sent six hundred copies to France and Spain. My friends assure me, that they are sold at Paris, and read and approved of even by the Sorbonists. Several learned men there have said, that they have long wished to see divine things treated with such becoming freedom. [Francesco] Calvus, a bookseller of Pavia, himself a scholar and addicted to the muses, has carried a great part of the impression into Italy." Luther's Correspondence and other Contemporary Letters, ed. Preserved Smith (Philadelphia: The Lutheran Publication Society, 1913), 125.

2 John E. Longhurst, Luther's Ghost in Spain, 1517-1546 (Lawrence, KS: Coronado, 1969), 13.

3 The Comuneros Revolt (1520-1521) was an uprising against young Charles V's policy of appointing his Flemish courtiers to lucrative posts. Many clerics of the cathedral chapter and of the regular religious orders also favored the rebellion.

4 Thomas M'Crie, History of the Progress and Suppression of the Reformation in Spain in the Sixteenth Century (Edinburgh: W. Blackwood, 1829), 126.

5 Alumbrados (illuminated ones) is a term used to loosely describe practitioners of a mystical form of Christianity practiced in Spain during the early fifteenth century.

6 Recogidos (withdrawn ones) was a reform movement within the Franciscan Order that practiced "active seclusion" in order to achieve union with God. The apocalyptic recogidos proposed a millennial program for the reform of the church. See Frances Luttikhuizen, Underground Protestantism in Sixteenth Century Spain (Göttingen:Vandenhoeck \& Ruprecht, 2016), 61. 
In 1528 he became cardinal and as such held a distinguished position in the Sacred College in Rome until his death.

Also present in Worms in 1521 was Juan de Vergara, a humanist scholar from Alcala who had been one of Cardinal Cisnero's secretaries. Vergara had left Alcala in 1520 for Flanders, where he became secretary to Cardinal Guillaume de Croÿ (one of Charles V's advisors) and a personal friend of Erasmus. Vergara remembered later that it was a common thing to hear people say that more men like Luther were bound to turn up; others said Luther was right in what he said, while yet others observed that Luther did well to burn the books of canons because they were not being used. In those days nobody was scandalized by such remarks. ${ }^{7}$ Vergara recalled that in Germany the court of his majesty was full of Luther's books ${ }^{8}$ and that

at first, when Luther only spoke of the need for reform in the Church ... everybody approved of him. The same persons who now write against him confess in their books that at first they were drawn to him. Almost the same thing happened in Spain in the matter of the comunero revolt; at first when these [revolutionaries] seemed only to be striving for certain reforms, everyone favored them. But later, when they began to behave in a shameful and reckless way, people of good sense withdrew from them and opposed them. ${ }^{9}$

On his return to Spain, Vergara became canon of Toledo and secretary to Alonso de Fonseca, Archbishop of Toledo (1523-34), another prominent humanist and staunch Erasmian. As the decade of the 1520s drew to a close, the anti-Erasmians were winning the day and in 1533, Vergara found himself arrested and formally denounced by the fiscal as a Lutheran, an Erasmian, and an alumbrado:

a heretic and apostate against our holy Catholic faith, following, holding, and believing and teaching the errors and perverse, damnable doctrine of the wicked heresiarch Martin Luther, keeping his books the better to learn and teach [the said errors], holding and believing at the same time the errors of those who are called Illuminists, which [errors] practically coincide with the said Lutheran errors. ${ }^{10}$

Of the twenty-two accusations leveled against him, the first eight referred specifically to Luther and his works.

7 Longhurst, Luther's Ghost in Spain, 284.

8 Ibid., 235.

9 Ibid., 284.

${ }^{10}$ Longhurst, Luther's Ghost in Spain, 230; Archivo Histórico Nacional (AHN), Inquisicion de Toledo, Proceso contra fuan de Vergara, Leg. 223, no. 42, ff. 133r-137r. 
In reply to these accusations, Vergara alleged that in the early days, before Luther's books were prohibited, he could have had them and read them because he was a doctor of theology. When he was in Germany with the emperor's court, in the service of Cardinal Guillaume de Croÿ, he recalled that at the time when Luther came to the Diet of Worms everybody, and especially the Spaniards, came there to see him. The following year, back in Spain in the service of Alonso de Fonseca, archbishop of Toledo, Vergara learned that his brother Bernardino Tovar, who was living in Alcala, had some Lutheran books. He did not know which books his brother had, but he knew he was always in the habit of buying new books. When Vergara was still in Germany, Tovar had asked him to send him books, but he did not recall Tovar asking him to send him any of Luther's books. However, if he had, and even ifVergara had understood such books to be "heretical," there still was no prohibition against them at that time. Instead, he contended, "it was considered a praiseworthy thing for a theologian, zealous for the faith, to want to see books by modern heretics in order to learn how to criticize and contradict their opinions."

\section{Official Reactions}

In March of 1521, only three months after Luther had been excommunicated, Pope Leo X addressed a brief to the Spanish authorities warning them against the introduction of Luther's books via the Spanish Netherlands. ${ }^{12}$ One month later, on April 7, 1521, even before the Diet of Worms had concluded, Adrian Florensz, now inquisitor general and regent of Spain, sent the inquisitors in Aragon the following directive against the writings of Luther:

We have been informed that some persons, with evil intent and in order to sow cockles in the Church of God and to rend the seamless tunic of Christ our Redeemer, have extended their efforts to bring into Spain the works recently written by Martin Luther, of the order of Saint Augustine, which works are said to be printed [in Spanish] for publication and sale in this kingdom. It is eminently proper for the honor and service of God and the exalting of our holy Catholic faith that such works not be published or sold, nor appear anywhere in this kingdom, because they contain heretical errors and many other suspect things about the faith. We therefore direct you to order, under pain of grave censures, as well as civil and criminal punishment, that nobody dare to own, sell, or permit to be sold in public or in private, any

\footnotetext{
${ }^{11}$ Longhurst, Luther's Ghost in Spain, 234-36.

12 On January 3, 1521, Pope Leo X issued the papal bull Decet Romanum Pontificem, which excommunicated Luther from the Catholic Church.
} 
such books or any parts of them, and that within three days of the publication of your order ... such books, in both Latin and Spanish, be brought and presented before you. When this is done you will then burn them all in public, directing the notary of your Holy Office to record the names of all persons who possess, sell, publish and bring before you such books, and the records of their burning, including the number of books burned. ${ }^{13}$

It is evident that these instructions were not strictly heeded: two years later, on May 7, 1523, the Suprema - the Supreme Council of the Inquisitionsent a letter to the inquisitors in Navarre denouncing the distribution of Lutheran books. Moreover, it appears that more books were being translated into Spanish: the edict states that under pain of excommunication and other heavy civil punishments, anyone who has in his possession any such books - in either Latin or Spanish - must turn them in within fifteen days. Six months later, in November 1523, the Council sent out another note:

We are informed that in the province of Guipuzcoa there are some of the said [Lutheran] books [in circulation], from which it appears that you did not take the proper action to carry out our directive or to do what we charged you to do. We are very surprised at this. ${ }^{14}$

As Longhurst notes, the inquisitor general, Alonso Manrique, issued an edict on April 15, 1525, in which he complained,

\begin{abstract}
"Some persons, showing little fear of God [and of the Inquisition] ... have brought into Spain and have in their possession many books of the accursed heretic Luther and his followers." All persons were ordered to bring to the Inquisition "whatsoever books and writings of any and all works written by the said perverse heretic and his followers," and to denounce any persons whom they knew or suspected of having such accursed books of that perverse heretic. ${ }^{15}$
\end{abstract}

By the 1530s, heresy hunting was becoming a national sport in Spain. A great public burning of Lutheran books was staged in Toledo; a similar event took place in Salamanca. ${ }^{16}$ Several of the leading Erasmians were brought to trial; others for the sake of prudence left the country. As the sixteenth century moved on, Erasmus's most popular book in Spain, the Enchiridion, was becoming a double-edged sword that either led people to

${ }^{13}$ Longhurst, Luther's Ghost in Spain, 14; AHN, Inquisicion, lib. 317, f. 182r-v.

${ }^{14} \mathrm{AHN}$, Inquisicion, lib. 319, f. 13v; f. 14r-v.

${ }^{15}$ Longhurst, Luther's Ghost in Spain, 18; citing AHN, Inquisicion de Toledo, Proceso contra Fuan de Vergara, Leg. 223, no. 42, ff. 15r-v.

${ }^{16}$ AHN, Inquisición de Toledo, Proceso contra fray Bernardo, Leg. 190, no. 4. Cf. Longhurst, Luther's Ghost in Spain, 20. 
greater Catholic piety or to heterodox views. ${ }^{17}$ Indeed, Erasmianism was much more than a simple movement of protest against the abuses of the unworthy clergy and some ignorant friars; rather, it was a positive movement of spiritual renovation. ${ }^{18}$ By the early 1540 s, though Erasmianism was no longer an articulate force in Spanish intellectual life, it had planted the seed of critical observation. As a result, many of the Spanish humanists who had earlier declared themselves Erasmians turned to the German Reformers, especially those Spaniards who had traveled abroad as part of the emperor's entourage or had taken part in the discussions at the imperial diet at Augsburg or at Trent.

\section{The Diet of Augsburg (1530)}

Alfonso de Valdés, who was present at the Diet of Augsburg in 1530, met Philip Melanchthon on that occasion. Thomas M'Crie provides details of this encounter that he gleaned from trustworthy sources:

In one of the conversations between these two learned men, held in the presence of Cornelius Schepper, an agent of the king of Denmark, Melanchthon lamented the strong prejudices which the natives of Spain had conceived against the reformers, and said that he had frequently endeavored, both by word of mouth and by letters, to convince them of the misconceptions under which they labored, but with very little success. Valdes acknowledged that it was a common opinion among his countrymen, that Luther and his followers believed neither in God nor the Trinity, in Christ nor the Virgin; and that in Spain it was thought as meritorious an action to strangle a Lutheran as to shoot a Turk. ${ }^{19}$

M'Crie contends that this event

had no inconsiderable effect in dissipating the false idea of the opinions of Luther which had hitherto been propagated. At the diet of Worms in 1521, the Spanish attendants of the emperor, instead of admiring the heroism displayed by Luther, treated him with insult. There was a marked difference in their behavior at Augsburg. Persons of note, including the emperor's confessor, who was a native of Spain, acknowledged that they had hitherto been deceived. ${ }^{20}$

${ }^{17}$ Jose C. Nieto, Fuan de Valdés and the Origins of the Spanish and Italian Reformations (Geneva: Droz, 1970), 182.

${ }^{18}$ Marcel Bataillon, Erasmo y España: estudios sobre la historia espiritual del siglo XVI (Mexico City: Fondo de Cultura Económica, 1966), 339.

${ }^{19}$ M'Crie, History of the Progress, 132-33.

${ }^{20}$ Ibid., 131. 
The public reading of the Augsburg Confession, the first Lutheran confession of faith, did not leave listeners indifferent. Not only the irenic spirit of the document but also its systematic presentation impressed theologians and laymen alike. This new attitude, if we can qualify it as that, did not change things in Spain, however. On June 13, 1530, the Suprema wrote, "there is reason to suspect that the writings of such heretics are now being brought to Spain and sold as approved works." All tribunals were urged to obtain from booksellers a list of all the books in their shops so that the books by authors whose names were unfamiliar might be examined for theological errors. Two months later the Suprema sent out another circular letter:

A few days ago we were informed that Martin Luther and others among the followers and adherents of his false opinions, and inventors of other new errors, realizing that they are unable to spread their books and poisonous doctrine in these lands as freely as they would like, have introduced many of their harmful opinions under the names of Catholic authors, giving false titles to their books, and in other instances inserting glosses and additions of false expositions and errors to well-known books of approved and good doctrine. All bookstores are to be diligently searched, and because such books might already be in the hands of private parties, the inquisitors are to include in future edicts against Lutheran books a provision requiring the faithful to come forward and inform them of any Lutheran literature in such Catholic disguise. ${ }^{21}$

The Suprema kept a vigilant eye on incoming literature and on March 28, 1534 , sent out a circular letter to the various courts of the Inquisition regarding Lutheran books:

As you know, some time ago we wrote you telling you to find a way that those that have books or writings or treaties of that evil heretic Martin Luther or of any of his followers or adherents should hand them over to you; and those that know of others who have them should tell to you. We believe this measure has been very successful. But because we know that many people from this country have gone to Germany in service of the Emperor, our Lord, where those evil heresies, for our sins, are very widespread and observed, it could have happened that they brought back some book, or books, containing that perverse doctrine and errors, it would be a good thing to publish the edicts anew and to add to the list more books and other authors that contain new errors and doctrines contrary to our holy Catholic faith and against the Holy Apostolic See. ${ }^{22}$

${ }^{21} \mathrm{AHN}$, Inquisicion, lib. 320, ff. 321v-322r and 343r-v.

${ }^{22}$ AHN, Inquisicion, lib. 573, f. 14. 


\section{Contact with the Northern Reformers}

Three individuals with inquiring minds in search of more satisfying spirituality and who had direct contact with the northern Reformers deserve mention: Francisco de Enzinas, Augustin de Cazalla, and Constantino de la Fuente.

\section{Francisco de Enzinas}

The Greek scholar Francisco de Enzinas (1518-1552), also known as Francis or Franz Dryander, was a native of Burgos. His uncle Pedro de Lerma had been professor of divinity at Alcala and had represented the pro-Erasmus faction at the conference in Valladolid in 1527 called to investigate Erasmus's writings. In 1537, Lerma was denounced to the Inquisition as suspected of Lutheran opinions and spreading Erasmian views. To avoid further trouble, he moved to Paris that year, where he became dean of the faculty of theology at the Sorbonne. About that same time, Francisco and his brother Diego were sent to Antwerp for commercial training in their uncle's firms, but instead of pursuing a promising business career, in 1539 they enrolled at the Collegium Trilingue of Louvain, possibly encouraged by their uncle. At Louvain, the two brothers fell under the spell of humanist scholarship. Indeed, it was Erasmus's influence that first turned them to the world of letters and, ultimately, the evangelical faith. From Louvain, Diego went to Paris and Francisco continued his studies of Greek under Philip Melanchthon at Wittenberg. In all likelihood Enzinas met Luther at this time, considering that the German Reformer was teaching there until January 1546.

In March 1542, Diego was back in Antwerp supervising the printing of a translation made by his brother Francisco of Calvin's 1538 Latin catechism, to which he had appended a translation of Martin Luther's Freedom of the Christian Man. The work contained a prologue by Francisco expressing the Protestant doctrine of justification by faith in a language and irenic spirit similar to that of his mentor Melanchthon..$^{23}$ The following year, Francisco finished his translation of the New Testament from Greek into Spanish. In the prologue he gave three reasons for such an undertaking:

All the other nations of Europe already enjoy the privilege of having the Bible translated into their language and they call the Spaniards superstitious because they still do not have the Bible in their language. No royal or papal decree prohibits

${ }^{23}$ The Spanish Inquisition learned of the plan, and his family sent him to Italy for safety. Diego Enzinas was arrested by the Roman Inquisition, tried, and sentenced to the stake in Rome in 1545. 
this publication. And although some may deem such translations dangerous in the time of heretics, be assured that heresies do not come from reading the Bible, but from the perverse explanations of evil men who distort the Holy Scriptures for their own perdition. ${ }^{24}$

He took the manuscript to Antwerp to be printed even though the required imperial imprimatur was missing from the title page. He had titled the work Nuevo Testamento, esto es, Nueva Alianza de nuestro redentor y único salvador Fesucristo (New Testament, that is, New Covenant of our Redeemer and only Savior Jesus Christ). Prior to the printing, there were objections to the words "only" and "covenant" for their "Lutheran connotations," and Enzinas found himself obliged to delete them..$^{25}$ Taking advantage of the fact that the emperor - to whom his New Testament was dedicated - was in Brussels, Enzinas arranged to present the first copy off the press to him personally. The emperor's remark, "Are you the author of this book?" revealed his supine ignorance regarding the Word of God. ${ }^{26}$ But it was the emperor's confessor Pedro Soto who a few days later objected strongly to the publication. He argued that until then Spain had remained free from heresy by prohibiting the Bible in the vernacular and that Enzinas had behaved most presumptuously by daring to publish his New Testament in Spanish in defiance to the laws of the land. ${ }^{27}$ The outcome was Francisco's arrest and imprisonment and the destruction of the entire edition. After a dramatic escape from prison in February 1545, Enzinas made his way back to Wittenberg and published an account of his adventures: De statu Belgico et religione Hispanica (Report on the Situation in Flanders and the Religion of Spain), known today as his Memorias. It covers the period from his return to Louvain from Wittenburg in April of 1543 and the executions he witnessed there, to the printing of his New Testament and his presentation to the emperor and his escape from prison in 1545.

The following year in Basel, he published an account of the murder of his friend Juan Diaz. From Basel he traveled to Geneva to meet Calvin. In 1548, he was in Strasbourg, where he became acquainted with Martin Bucer and Caspar Hedio, ${ }^{28}$ and where he met and married Margaret d'Elter, a fellow religious exile from Belgium. ${ }^{29}$ Almost immediately, in solidarity with the

24 "Francisco de Enzinas (1520-1552)," Grandes traductores de la Biblia, Promotora Española de Lingüística, www.proel.org/index.php?pagina=traductores/enzinas.

${ }^{25}$ Francisco de Enzinas, Memorias, trans. Francisco Socas (Madrid: Clásicas, 1992), 149-53.

${ }^{26}$ Ibid., 160.

${ }^{27}$ Ibid., $180-81$.

${ }^{28}$ Matthias Zell passed away that year. After the death of Bucer in England in early 1551, Hedio was the last surviving leader of the first generation of Reformers at Strasbourg.

${ }^{29}$ Both Enzinas and his wife, as well as Hedio, died of the plague that hit Strasbourg in 1552. 
ousted pastors as a result of the imposition of the Augsburg Interim that ordered Protestants to readopt traditional Catholic beliefs and practices, the couple left for England. With letters of recommendation from his friend Melanchthon to Bishop Thomas Cranmer, Enzinas was appointed professor of Greek at the University of Cambridge. That year he was also on a committee with Cranmer, Bucer, Peter Martyr Vermigli, Pablo Fagius, and Immanuel Tremellius - fellow exiles-deliberating the reform of the Book of Common Prayer; this indicates both his level of scholarship and the high esteem the Reformers had for him. Enzinas's Memoirs and his collected letters, which include correspondence with Melanchthon, Bullinger, Bucer, Calvin, Laski, and other Reformers, offer an interesting dimension to the history of the Reformation that deserves more attention. ${ }^{30}$

\section{Augustin de Cazalla}

Dr. Augustin de Cazalla (1510-1559), described by the Spanish historian Gonzalo de Illescas in his Historia Pontifical (1568) as "the most eloquent preacher in Spain at the time," had studied at the College of Saint Gregorio in Valladolid under Bartolome de Carranza and at the University of Alcala de Henares under his uncle, Bishop Juan de Cazalla, former chaplain of Cardinal Cisneros. From his youth, Cazalla and his siblings had been exposed to heterodox opinions. Their father, Pedro de Cazalla, was a close friend of the Vergara brothers, Juan and Francisco, and shared their sympathies for Luther; their mother had had close links with the alumbrados.

Cazalla entered the service of Charles V in 1543 as court preacher and personal chaplain. This allowed him to travel throughout Europe with the emperor for the next ten years, during which time he had contacts with some of the most prominent Protestant leaders. He would have been present when Francisco de Enzinas presented his translation of the New Testament to the emperor in Brussels in 1543 and would have witnessed how the emperor's confessor had Enzinas arrested and his New Testaments burned. Cazalla would also have accompanied the emperor to Regensburg in 1546, where Bucer and Johann Pistorius were the main Protestant interlocutors, and where he would have learned of the death of Luther. Cazalla may not have been physically present in Augsburg, since the emperor had delegated his brother Fernando, but he would have been aware of the theological debates that centered on the Augsburg Confession and the defense of the

${ }^{30}$ Francisco de Enzinas, Epistolario, trans. Ignacio J. García Pinilla, Travaux d'humanisme et Renaissance 290 (Geneva: Droz, 1995). 
confession written by Melanchthon. ${ }^{31}$ He certainly was present when Charles V decreed the Augsburg Interim in the spring of 1548 after he had defeated the forces of the Smalcald League. Was Charles V's "Proclamation Against Heretics" (April 1550) that allowed the Inquisition in the Netherlands to arrest any heretic an eye-opener for Cazalla? Was he present when a Protestant victory forced Charles to sign the Peace of Passau on August 2, 1552, which granted some freedoms to Protestants and ended Charles's hopes of religious unity within his empire?

In any case, by the end of 1552, Cazalla was back in Spain, first as canon preacher of the cathedral in Salamanca and in 1556 in Valladolid as chaplain to some noble families and spiritual director of the Cistercian nuns at the Monastery of Belen. Through his brother Pedro, the parish priest at Pedrosa del Rey, Augustin Cazalla may have met the Italian nobleman Carlo de Sesso, who was busy sharing his newly found faith with his acquaintances. Sesso, who had lived in Spain since he was a young boy, returned to Italy in 1550 to collect an inheritance and there came in contact with Calvinists in Vicenza. Sesso returned to Spain a changed man. He also returned with books he eagerly began sharing with his acquaintances: Calvin's Institutes and several of his commentaries, ${ }^{32}$ Wolfgang Musculus's commentaries on Matthew and John, ${ }^{33}$ Joannes Brenz on John and Luke, ${ }^{34}$ and Luther's Canticum graduum, or commentary on Psalm 130, traditionally called De profundis. He also brought back several copies of Juan de Valdes's 110 Considerations in Italian, which had just come off the Oporino press in Basel. ${ }^{35}$

Around Easter of 1558 the inquisitors began incarcerating evangelicals in Valladolid. The Carranza siblings were the first to be seized. The inquisition records the proceedings of the auto-da-fé held on May 21, 1559, at which Dr. Augustin Cazalla was sentenced to the stake over details regarding his theological position:

The first [sentence] was that of Dr. Augustin de Cazalla, which was read from that same pulpit. Dr. Cazalla stood up to hear his sentence. The case against Dr. Augustin de Cazalla was this: The prosecutor of the Holy Inquisition of Valladolid said that

${ }^{31}$ Charles P. Arand, "The Texts of the Apology of the Augsburg Confession," Lutheran Quarterly 12.4 (1998): 461-84.

${ }^{32}$ Jean Calvin, Institutio Totivs Christianae Religionis (Geneva, 1550); Commentarii in Epistolam Pauli ad Romanos (Strasbourg, 1540); Commentarii in priorem Epistolam Pauli ad Corinthios (Strasbourg, 1546); Commentarii in 4 epistolas ad Gal., Ephes., Philip., Coloss. (Geneva, 1548).

${ }^{33}$ Wolfgang Musculus, Commentariorvm in evangelistam Ioannem (Basel, 1545); In Evangelistam Matthaeum Commentarii (Basel, 1544).

34 Joannes Brentius, Evangelion qvod inscribitvr, secvndvm Ioannem (Frankfurt, 1551); In Evangelii quod inscribitur secundum Lucam (Frankfurt, 1551).

${ }^{35}$ Juan de Valdés, Le cento et dieci divine considerationi del S. GiovanniValdesso (Basel, 1550). 
when Dr. Augustin de Cazalla was in Germany he had read, and continues to read, the works of Lutheran heretics and had learned their ways and customs and, in particular, preached and taught the doctrine of the sect of the heretic Martin Luther, and that for many years he had held these doctrines and taught them. The heresies of which he was accused were these: first, that he and his followers called themselves alumbrados; secondly, that if one has a living faith that Jesus Christ our Redeemer had paid for the sins of the human race the day he died on the cross, that believing this he was justified and that no other works were necessary for his salvation. He also rejected fasting, oral prayers and oral confession and acknowledged only two sacraments, namely, baptism and the Eucharist. ... Likewise, man's free will did not allow him to do good but only evil. And Cazalla was a teacher and preacher of these false doctrines and other great offenses against the holy Catholic faith. ${ }^{36}$

\section{Constantino de la Fuente}

Another court preacher later condemned for his heretical opinions was Dr. Constantino de la Fuente (1502-1560) from Seville. Calvete de Estrella described him as "a profound theologian, and one of the most notorious and eloquent men in the pulpit." ${ }^{37}$ The paths of these two famous preachers crossed briefly in Brussels in 1549 and again in 1550. In the summer of 1548 Constantino had been appointed Crown Prince Philip's preacher for his European tour. The tour took them to Genoa, Milan, Mantua, Trent, Innsbruck, Munich, Augsburg, Heidelberg, Ghent, Louvain, and other places, and finally ended in Brussels, where Philip's father the emperor held his court. On the return trip Prince Philip stopped again at Augsburg, which coincided with another session of the diet. The prince and his entourage attended the opening session held on July 8, 1550, where there were delegates, both Catholic and Protestant, from Mainz, Trier, Cologne, and the Palatinate. Was it there that Constantino became acquainted with Jakob Schopper, a Lutheran preacher from Biberach, ${ }^{38}$ "mentioned as one who met with him, and [whose] conversation was useful in opening up Protestant truths"? ${ }^{39}$ They very likely discussed the office of preacher, Constantino's pet subject, and also the topic of human depravity, one of Schopper's deep concerns. ${ }^{40}$ Popular piety had decreased in Germany at the close of the

${ }^{36}$ Real Biblioteca de Palacio, II-2403, in Ernst H. J. Schäfer, Protestantismo Español e Inquisición en el Siglo XVI, trans. Francisco Ruiz de Pablos, 4 vols. (Seville: Editorial MAD, 2014), 3:7-23, doc. 377. For the full accusation, see Luttikhuizen, Underground Protestantism in Sixteenth Century Spain, 118-19.

37 Juan Cristoval Calvete de Estrella, El felicissimo viaje del muy alto y muy poderoso principe Don Phelippe (Antwerp: M. Nucio, 1552), f. 7v.

38 Schopper is the father of the theologian Jakob Schopper.

${ }^{39}$ M'Crie found this information in Oratio de vita et obitu fohannis Hochmanni, recitata in Acad. Altorphina. Cui accessit historica narratio, de vita et obit. Facobi Schopperi conscripta a facobo Schoppero (Tubingae: Cellianis, 1605), 26-28.

40 Constantino was noted for making fun of "foolish preachers," or as Reginaldo Gonzalez de Montes puts it, "Most of all, he used to grid the foolish preachers, whereof there was never 
Middle Ages. Growing luxury had spread through all ranks of society and sapped their stability; religion and morality were in many places at a low ebb. ${ }^{41}$ In 1545 , Schopper showed great pessimism regarding the fruits of the new preaching: ".. the young people, in these last thoroughly corrupt times, plunged into a variety of vices; an era of complete barbarism is setting in." ${ }^{\prime 2}$ Repeatedly at this period Luther expressed the wish that he and his loved ones might be snatched by a speedy death out of this "Satanic age." The cradle of the new evangel, Wittenberg, seemed to him a second Sodom, and the zealous, new-religion Leipzig, with its pride and its avarice, still worse than Sodom. ${ }^{43}$

At Augsburg, Constantino also made acquaintance with Caspar von Nidbruck, the "undercover Protestant" diplomat, as Alexandra Kess calls him. ${ }^{44}$ Nidbruck had asked Francisco de Enzinas, who had just returned to Strasbourg from London and was busy trying to find a printer for his translations of Lucian, Livy, and Plutarch, to arrange the meeting. The friendship between Enzinas and Nidbruck went back to their student days in Wittenberg under Melanchthon in 1546. When Wittenberg University closed on November 6, 1546, because of the Smalcald War, Nidbruck transferred to the University of Erfurt, and the following year he left for Padua, where he received a doctorate in law. ${ }^{45}$ He was back in Vienna in 1550 and had kept in touch with Enzinas all this time. It is difficult to believe that Nidbruck's interest in meeting Constantino was due merely to the fact that he was considered one of Spain's most eminent preachers. Both Enzinas and Nidbruck must have been aware of Constantino's religious empathies. Nevertheless, Nidbruck's instructions to Enzinas were these:

You need not mention the topic of religion [to Constantino], and without your engaging me too much by your promises, you may affirm this, that what he shall communicate to me will be entrusted to a confidential person. Were you disposed to

any age so full, whom the Holy Scriptures account to be the vilest sort of people that are, comparing them to salt that has lost his savor and will serve to no use.” Reginaldo Gonzalez de Montes, A Discovery and playne Declaration of Sundry Subtill Practises of the Holy Inquisition of Spayne (London: John Daye, 1569), f. 92r.

${ }^{41}$ Johannes Janssen, History of the German People after the Close of the Middle Ages, trans.

A. M. Christie, 16 vols. (London: Kegan Paul, Trench. Trubner \& Co, 1910), 16:1.

${ }^{42}$ Ibid., 16:28.

${ }^{43}$ Ibid., 16:20. For an overview of the pessimistic assessment of the times, see ibid., $16: 1-136$.

${ }^{44}$ Alexandra Kess, Fohann Sleidan and the Protestant Vision of History (Aldershot: Ashgate, 2008), 136.

${ }^{45}$ Luka Ilic, "Calvin, Flacius, Nidbruck, and Lutheran Historiography," in Herman J. Selderhuis and Arnold Huijgen, eds., Calvinus Pastor Ecclesiae: Papers of the Eleventh International Congress on Calvin Research (Göttingen:Vandenhoeck \& Ruprecht, 2016), 321. 
confer with him upon your own affairs, that would be best done by your informing him of them when I shall be at Augsburg, for I shall easily ascertain how he is affected towards pure Evangelical doctrine, and how he is affected towards you, as also what others think of you. ${ }^{46}$

These words indicate how cautious persons were of committing themselves on the subject of religion. After the interview, Nidbruck wrote again to Enzinas, saying,

The venerable man, Dr. Constantino, has received me with great friendliness, and, what with his wisdom and learning, I doubt not that he will be able, assisted by your counsel, to promote what I have proposed, which he promised that he will do, and I do not mistrust his good will. ${ }^{47}$

There is no record of what Nidbruck had in mind with the phrase "to promote what I have proposed," but considering that he was royal librarian for Emperor Ferdinand I in Vienna, and that he belonged to the diplomatic core, their conversation must have centered around books. Nidbruck was well connected ${ }^{48}$ His position at the Habsburg court would have allowed him to pursue contacts with Catholics and Protestants alike, especially bearing in mind Maximilian II's rather tolerant attitude towards Protestantism. ${ }^{49}$ Was Nidbruck already beginning to gather information for Matthias Flacius's proposed church history? Did he know that Constantino's friend Dr. Egidio had just been arrested on charges of preaching Lutheran doctrines? What advantages did the meeting at Augsburg with Nidbruck have for Constantino? Were arrangements made for Nidbruck to send Constantino literature via diplomatic service? Was the arrival in Seville in the fall of 1550 of a large trunk of "Lutheran" books sent from Brussels by Gaspar Zapata, camouflaged between the belongings of a nobleman returning to Seville, a result of this meeting? ${ }^{30}$ The trunk of books was seized and a dispatch was immediately sent from the Suprema to Emperor CharlesV in Brussels, stating,

${ }^{46}$ John Stoughton, The Spanish Reformers: Their Memories and Dwelling-Places (1883; repr., London: Forgotten Books, 2013), 140.

${ }^{47}$ Ibid., 141.

${ }^{48}$ Ilic, "Calvin, Flacius, Nidbruck," 319-32.

${ }^{49}$ Kess, Fohann Sleidan, 133.

${ }^{50}$ Timewise, this is perfectly feasible. The two men met in April. The trunk of books arrived in the fall. 
Instructions for his majesty's court: First, let Gaspar Zapata, servant of Fadrique Enriquez, brother of the Marquis of Tarifa, who lives in his majesty's court, be examined under oath and tell and declare if he knows where the priest Diego de la Cruz, who lived some years in Seville and is now in Flanders. Gaspar Zapata should also be asked if he delivered a trunk of Lutheran books to Antonio de Guzman, a knight from Seville, when he left Brussels. These books have been seized by the Inquisitors at Seville. Have him declare who the books were for and if he sent them in his own name or in the name of another, and who wrote to him asking him to send them and who bought them and anything else related to this business, such as what he did with them before he embarked, etc., that is, anything else that might shed light on the case. This information should then be carefully and secretly sent to the Inquisitor General or to the Supreme Council of this kingdom of Spain in a sealed envelope. ${ }^{51}$

The very fact that the Suprema insisted on such secrecy makes us suspect that these "Lutheran" books were meant for Constantino. In the list of confiscated books inventoried around 1563, there are three works published in Augsburg, which could have been purchased by Constantino that day in 1550 or sent later. The three books were Arsatius Schofer's Enarrartiones Evangeliorum Dominicalium (Augsburg, 1539), Bernardino Ochino's Expositio Epistole diui Pauli ad Romanos (Augsburg, 1550), and Omnium operum Divi Avrelii Avgvstini, episcopi hipponensis (Augsburg, 1537), a collection of Saint Augustine's works by Johannes Pistorius the Elder (Johannes Pessellius). These confiscated books may have formed part of Constantino's secret library discovered by the inquisitors in 1561 .

Another confiscated library was the one belonging to the Dominican friar Domingo de Guzman. Guzman was among the recipients of the books smuggled in by Julian Hernandez in the summer of 1557. When the inquisitors got word that Guzman was one of the recipients, orders were given that he be confined to his rooms while his books and papers were taken to Triana for examination. ${ }^{52}$ It took the inquisitors over a month to examine his large library. Finally, on March 3, 1558, Guzman himself was taken to Triana and put in solitary confinement. ${ }^{53}$ His books, already confiscated, were put in secret keeping. Instructions were sent from the Supreme Council that no one should have access to them. A year later, on November 2, 1559, the Council asked the inquisitors at Seville to search among them for a commentary by Luther on Isaiah or on the Prophets, and also one on the Epistle of Paul to the Galatians. The commentaries were found and duly

\footnotetext{
${ }^{51}$ AHN, Inquisición, lib. 574, f. 216 r.

${ }^{52}$ Ibid., lib. 575, ff. 57r-57v.

${ }^{53}$ Ibid., lib. 575, f. 59r.
} 
sent to Toledo. Information regarding Guzman is scanty. The text appended to the 1569 English edition of Montes's Artes reads thus:

In the same Act there was brought onto the scaffold one called Fray Domingo de Guzman, a Dominican Friar and a preacher, one of the cloister of St. Paul in Seville, who, having brought divers Lutheran books (as they commonly term them in Spain), lent the same to divers in Seville, and began to profess the gospel and to preach it to others, whereupon, he was apprehended and committed to prison. But, for as much as he was bastard brother to the Duke of Medina Sidonia, and in hope of preferment to some archbishopric, he openly recanted. Howbeit, the inquisitors, fearing to allow any that had been at any time inclined towards like heresy to be preferred to any such place of authority and countenance, first commanded that all his books, which were about 1000 volumes, should be burnt before his face, despite his recantation, and awarded him to perpetual prison. ${ }^{54}$

Fray Guzman's sentence, pronounced at the auto-da-fé held in Seville on July 11, 1563, sheds more light on his involvement in the evangelical movement at Seville:

Fray Domingo de Guzman, preacher of the Order of Santo Domingo, resident in the monastery of San Pablo of Seville. For things of the Lutheran sect and for having favored and protecting persons of the Lutheran sect and having brought out of Flanders many copies of heretical books and for having them a lot of time in his possession and reading in them and discussing with other persons that belonged to the above mentioned Lutheran sect, is sentenced to appear on the scaffold in a simple robe and a low scapular, with his head uncovered and a wax candle in his hand. He is to publicly retract the proposals in the memorial signed by the inquisitors, and be declared suspicious, in accordance with the memorial. $\mathrm{He}$ is to abjure de vehementi [solemnly renouncing a major error] ${ }^{55}$ and be dismissed from his order and removed from the office of priest. He is not allowed to celebrate Mass, confess, preach, discuss, read, speak or communicate with anyone other than those persons permitted by the lord inquisitors. He is permanently prohibited to voice his opinion, either actively or passively, and is to be confined for life in the monastery or prisonhouse designated and is to comply with the spiritual and temporal penitence assigned him under penalty of backsliding. And all the books found in his possession must be burned publicly in San Francisco square. ${ }^{56}$

\footnotetext{
${ }^{54}$ Montes, $A$ Discovery, Appendix.

${ }^{55}$ Montes elaborates on the term: "They call it Abjuration de vehementi when, in hearing and debating any man's cause, it is not clear what is to be determined due to lack of sufficient proof, and because the party himself confessed nothing that deserved any manner of punishment. Therefore, upon such a fellow, whom they can neither by justice condemn for a heretic, nor of their consciences absolve and set at liberty for a good Catholic, they give sentence upon him as upon one 'vehemently suspected.' And so, according to their suspicion, they cause him to abjure. And such a man, being afterward found guilty, be it in the least matter touching papistry, they take for a relapse and condemn to the fire." Montes, $A$ Discovery, f. $58 \mathrm{r}$.
}

${ }^{56}$ AHN, Inquisición, leg. 2075, doc. 3. 


\section{Conclusion}

Despite the edicts and confiscations, prohibited literature continued to arrive. In 1563 and again in 1564 numerous bales coming from Lyon were intercepted at the French border. ${ }^{57}$ From Lyon books were shipped to La Rochelle, an important Huguenot stronghold on the Atlantic coast, and from there were sent camouflaged along with other merchandise to Seville. One would suppose that after the severe repression and the autos-de-fé carried out between 1558 and 1563, there would have been no potential buyers or readers of Protestant literature left in Seville. The authors of the books reported confiscated in 1563 in Seville, many of which may have belonged to either Constantino's or Guzman's library, include

Aemilius, Agricola, Agrippa, Althamerus, Aretius, Atropaeus [Becker], Bibliander, Bonnus, Brenz (12), Brunfels, Bucer, Bullinger (8), Calvin (10), Capito, Clauserus, Corvinus, Creutziger, Culmann, Curione, Draconites, Erasmus, Fagius, Flacius, Flavius, Gallus, Gast, Gesner, Hegendorphius, Hoffman, Hyperius, Indagine, Jonas, Kling, Lagus, Lambertus, Lazius, Lefèvre d'Étaples, Lorich, Lossius, Luther, Megander, Melanchthon (10), Meyer, Münster, Musculus, Obsopeus, Oecolampadius (10), Osiander, Patavinus, Pellicanus, Piscator [Pessellius], Postel, Pupper von Goch, Regius, Rivius, Sarcerius (16), Schofer, Sleidanus, Spangenberg, Spira, Urspergensis, Vadianus, Venatorius, Vergilius, Vermigli, Viret, Vitus, Wellerus, Werdmüller, Westhemerus, Willich, Zwingli. ${ }^{58}$

Enlarging the Index did not solve the problem. Clandestine literature continued to enter or come to light. Among the two hundred confiscated books inventoried in 1583 by Dr. Heredia were a dozen Spanish Bibles, Calvin's commentary on Isaiah, Musculus's commentary on Romans, Savonarola's Exposicion del psalmo Inte domine speraui, a book by Justus Jonas, several by Petrus Ramus and by Conrad Gesner, and a half dozen by Erasmus. ${ }^{59}$ That the majority of all these volumes were in Latin implies a highly educated readership. Were they priests or laypersons? Likewise, the vast range of authors implies a knowledgeable readership. Who chose the titles?

Hopefully this brief sketch of the impact of Luther and the first generation of northern Reformers on the Spanish Reformers may encourage further study. The impact of Calvin and the second generation of northern Reformers on Juan Perez de Pineda and the Hieronymite monks that fled Seville in 1557 requires another essay.

\footnotetext{
${ }^{57}$ Werner Thomas, La represión del protestantismo en España, 1517-1648 (Leuven: Leuven University Press, 2001), 242.

${ }^{58}$ See Luttikhuizen, Underground Protestantism, Appendix A. Numbers between brackets indicate an exceptional number of titles.

${ }^{59} \mathrm{AHN}$, Inquisición, leg. 4426, doc. 31.
} 


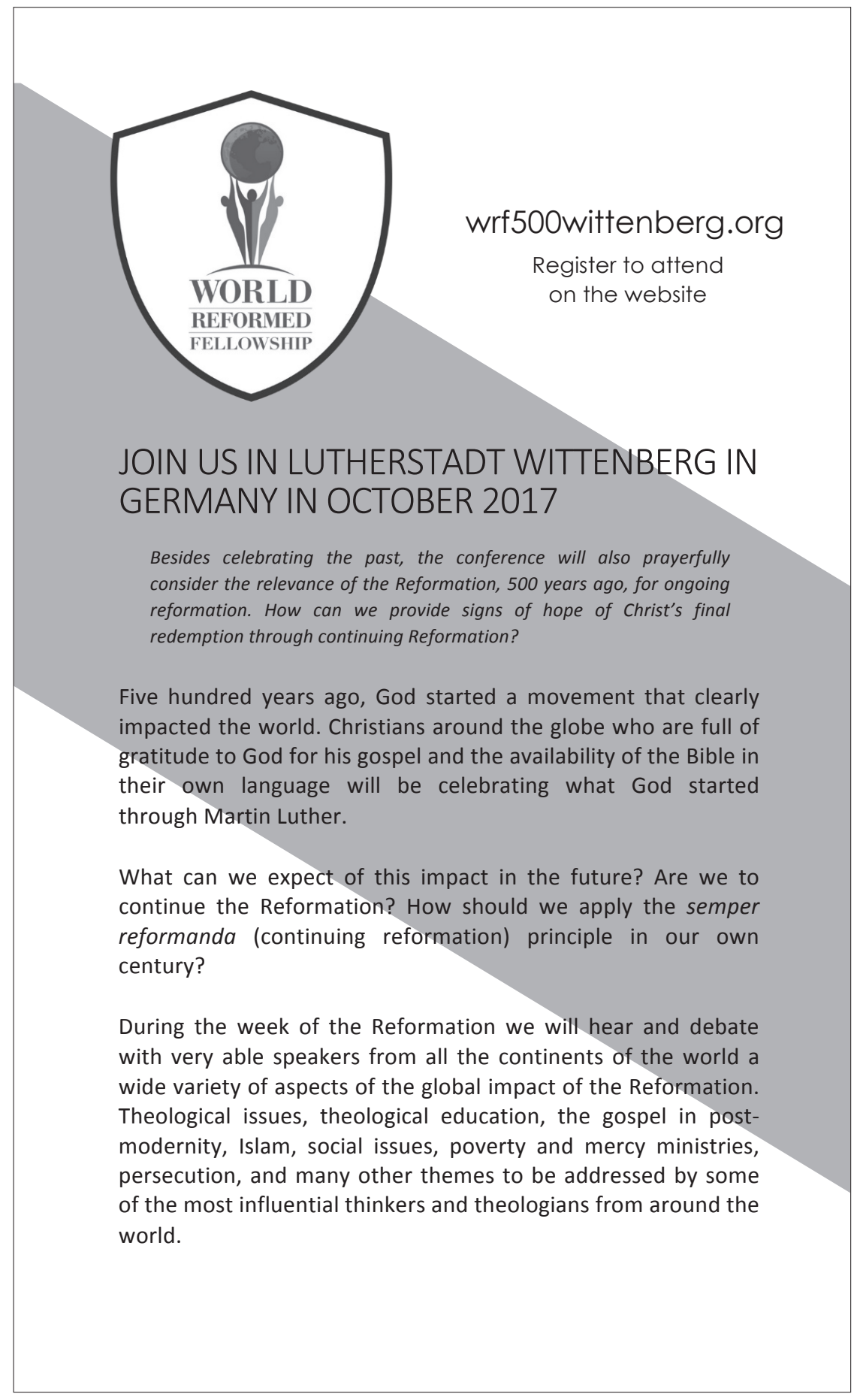




\title{
"The Glorious Work of the Reformation": Andrew Fuller and the Imitation of Martin Luther
}

\author{
MICHAEL A. G. HAYKIN
}

\begin{abstract}
While a high view of the life and work of Martin Luther was maintained only in certain quarters of Anglophone Christianity by the close of the seventeenth century, the eighteenth-century Evangelical revival led to a profound rediscovery of him. This article examines the way one such Evangelical, the Baptist Andrew Fuller, who does not appear to have read Luther directly, regularly cited him as a model to be imitated when it came to preaching and courageous action.
\end{abstract}

$\mathrm{t}$ is ironic that Martin Luther's memory in English-speaking circles in the two centuries or so after his death was cherished largely by men and women whom the German Reformer would have regarded probably as "fanatics." As J. Wayne Baker has noted, it was high Calvinists like John Saltmarsh (died 1647), Henry Denne (died ca. 1660), and John Bunyan (1628-1688), the latter two figures also Baptists to boot, who especially admired Luther as the herald of justification by grace alone. ${ }^{1}$

1 J. Wayne Baker, "Sola Fide, Sola Gratia: The Battle of Luther in Seventeenth-Century England," Sixteenth Century fournal 16.1 (Spring 1985): 115-33. More generally, see Preserved Smith, "English Opinion of Luther," Harvard Theological Review 10.2 (April 1917): 129-58. 
During the 1640s, at the height of what should be regarded as the first Antinomian controversy - the second being in the 1690s-Saltmarsh noted that he could have cited Luther in favor of his position on God's grace, but he observed, "He is now lookt [ $s i c]$ on by some as one that is both overquoted, and over-writ Free-grace."2 Two decades later, however, Bunyan was not afraid of going public in his autobiographical Grace Abounding to the Chief of Sinners (1666), about the utterly central role that Luther and his commentary on Galatians had played in enabling him to find a stable faith: "Methinks I must let fall before all men, I do prefer this book of Mr Luther upon the Galatians (excepting the Holy Bible) before all the books that ever I have seen, as most fit for a wounded conscience." ${ }^{3}$ By the bicentennial of Luther's death in 1683, though, such admiration of Luther was increasingly that of an embattled minority. Moralism not only dominated Anglican pulpits, but even among Dissenting authors like Richard Baxter (1615-1691) there was the opinion that Luther had sometimes expressed himself carelessly when it came to justification by faith. ${ }^{4}$

The Evangelical revival, which broke thunderously upon the British Isles in the 1730s and 1740s, changed this whole situation. Justification by grace and faith alone once more became central themes in preaching and worship, and Luther cited as an example to be emulated. Luther's commentaries on Galatians and Romans were crucial influences in the 1738 conversions of both John (1703-1791) and Charles Wesley (1707-1788), for example, and the Reformer's doctrine of justification by faith alone central in their subsequent preaching and hymnic arsenal. ${ }^{5}$ In the mid-1750s their friend and

See also Brilliana Harley, Letter to Edward Harley, May 10, 1639, in Letters of the Lady Brilliana Harley, ed. Thomas Taylor Lewis (London: Camden Society, 1854), 52-53, for aspects of the debate about Luther. In this letter, Brilliana also observed that Luther "had great fears till he had thoroughly learned the doctrine of justification by Christ alone."

2 John Saltmarsh, Free-Grace: or, The Flowings of Christ's Blood Free to Sinners, 2nd ed. (London: Giles Calvert, 1646), 210.

3 John Bunyan, Grace Abounding to the Chief of Sinners, ed. W. R. Owens (London: Penguin, 1987), 35. On Bunyan's indebtedness to Luther in this work, see especially Vera J. Camden, “"Most Fit for a Wounded Conscience': The Place of Luther's 'Commentary on Galatians' in Grace Abounding," Renaissance Quarterly 50.3 (Autumn 1997): 819-49. See also Dayton Haskin, "Bunyan, Luther, and the Struggle with Belatedness in Grace Abounding," University of Toronto Quarterly 50.3 (Spring 1981): 300-313; and Christopher Hill, A Tinker and a Poor Man: Fohn Bunyan and His Church, 1628-1688 (New York: Knopf, 1989), 157-60.

Of Galatians, Luther once remarked in his Table Talk, "The epistle to the Galatians is my epistle. I have betrothed myself to it" (cited in Alfred Williams Anthony, "Criticism of the Epistle to the Galatians," The Old and New Testament Student 12.2 [February 1891]: 96).

4 Baker, "Sola Fide, Sola Gratia," 129-30.

5 John Munsey Turner, fohn Wesley: The Evangelical Revival and the Rise of Methodism in England (Peterborough: Epworth, 2002), 27-29; Gary Best, Charles Wesley: A Biography (Peterborough: Epworth, 2006), 91. 
fellow Evangelical George Whitefield (1714-1770) specifically prayed for men of Luther's caliber to be raised up to preach the gospel: "What a spirit must Martin Luther, and the first Reformers be endued with, that dared to appear as they did for God! Lord, hasten that blessed time, when others, excited by the same spirit, shall perform like wonders." ${ }^{\prime \prime}$ Again, nearly twenty years later, at the time of the conversion of Thomas Charles (1755-1814) of Bala in January 1773, the future Welsh Calvinistic Methodist leader noted that "Luther's exposition of Galatians 1:4 was very much and particularly blessed to me."” John Newton (1725-1807), preaching in London in 1786, well summed up this new appreciation of Luther and his doctrine of justification:

The justification of a sinner before God, by faith in the obedience and atonement of Christ, is considered by many persons, in these days of refinement, in no better light than as a branch of a scholastic theology, which is now exploded as uncouth and obsolete. At the Reformation, it was the turning point between the Protestants and Papists. Luther deemed it the criterion of a flourishing, or a falling Church; that is, he judged that the Church would always be in a thriving or a declining state, in proportion as the importance of this doctrine was attended to. ${ }^{8}$

\section{Introducing Andrew Fuller}

Another fan of Luther was the Particular Baptist theologian Andrew Fuller (1754-1815), who was an heir of both the seventeenth-century high Calvinists and the eighteenth-century Evangelicals. As the most important Baptist theologian of his era ${ }^{9}$ and one who was deeply respected by men like William Wilberforce (1759-1833), Timothy Dwight (1752-1817), and Thomas Chalmers $(1780-1847),{ }^{10}$ his various references to Luther, scattered throughout

6 George Whitefield, Letter to Mr. C-, March 26, 1754, in The Works of the Reverend George Whitefield, M.A. (London: Edward and Charles Dilly, 1771), 3:68.

7 Cited Eifion Evans, Daniel Rowland and the Great Evangelical Awakening in Wales (Carlisle, PA: Banner of Truth Trust, 1985), 331-32.

8 John Newton, Sermon XLVI in his Messiah: Fifty Expository Discourses (1786) in The Works of the Reverend Fohn Newton (London: George Virtue, [1839]), 711.

9 In his funeral sermon for Fuller, John Ryland Jr. (1753-1825) described him as "perhaps the most judicious and able theological writer that ever belonged to our denomination" (The Indwelling and Righteousness of Christ No Security against Corporeal Death, but the Source of Spiritual and Eternal Life [London, 1815], 2-3). The Victorian Baptist preacher C. H. Spurgeon (1834-1892) similarly described Fuller as the "greatest theologian" of his century (cited in Gilbert Laws, Andrew Fuller: Pastor, Theologian, Ropeholder [London: Carey, 1942], 127). More recently, the English Evangelical historian David Bebbington has spoken of Fuller's "extraordinary importance in the history of theology" (email to the author, March 11, 2009).

${ }^{10}$ Robert Isaac Wilberforce and Samuel Wilberforce, The Life of William Wilberforce (London: Murray, 1839), 3:388-89; Peter J. Morden, Offering Christ to the World: Andrew Fuller (17541815) and the Revival of Eighteenth-Century Particular Baptist Life, Studies in Baptist History and Thought 8 (Milton Keynes: Paternoster, 2003), 98-99. 
his works, carried significant clout in elevating the respect in which Luther was held in the British Isles by the tercentennial of his birth and well into the nineteenth century.

Fuller was born in Wicken, a small agricultural village in Cambridgeshire. ${ }^{11}$ His parents, Robert Fuller (1723-1781) and Philippa Gunton (1726-1816), were farmers who rented a succession of dairy farms. In 1761 his parents moved a short distance to Soham, where he and his family began to regularly attend the local Particular Baptist church, and where Fuller was converted in November, 1769. After being baptized the following spring, he became a member of the Soham church. In 1774 Fuller was called to the pastorate of this work. He stayed until 1782, when he became the pastor of the Particular Baptist congregation at Kettering, Northamptonshire. His time as a pastor in Soham was a decisive period for the shaping of Fuller's theological perspective. It was during these years that he began a life-long study of the works of the American divine Jonathan Edwards (1703-1758), ${ }^{12}$ which, along with his knowledge of the Scriptures, ${ }^{13}$ gave him the theological resources to pen definitive responses to hyper-Calvinism - a by-product of seventeenth-century high Calvinism - and Sandemanianism, as well as impressive rebuttals of Socinianism and Deism. ${ }^{14}$

Fuller was also deeply involved in the emergence of the modern missionary movement. He served as the first secretary of the Baptist Missionary Society

${ }^{11}$ For Fuller's life, the classic study is that of John Ryland, The Work of Faith, the Labour of Love, and the Patience of Hope, Illustrated; in the Life and Death of the Rev. Andrew Fuller, 2nd ed. (London: Button \& Son, 1818).

The two best recent biographies are those of Paul Brewster, Andrew Fuller: Model PastorTheologian (Nashville: Broadman \& Holman Academic, 2010) and Peter J. Morden, The Life and Thought of Andrew Fuller, 1754-1815 (Milton Keynes: Paternoster, 2015). For brief studies, see Phil Roberts, "Andrew Fuller," in Timothy George and David S. Dockery, eds., Theologians of the Baptist Tradition, rev. ed. (Nashville: Broadman \& Holman, 2001), 34-51, and Michael A. G. Haykin, "Fuller, Andrew," in Timothy Larsen, D. W. Bebbington, and Mark Noll, eds., Biographical Dictionary of Evangelicals (Downers Grove, IL: InterVarsity Press, 2003), 241-44.

${ }^{12}$ For Edwards's influence on Fuller, see Chris Chun, The Legacy of fonathan Edwards in the Theology of Andrew Fuller (Leiden: Brill, 2012).

${ }^{13}$ For example, he could state: "If any man venerate the authority of Scripture, he must receive it as being what it professes to be, and for all the purposes for which it professes to be written. If the Scriptures profess to be Divinely inspired, and assume to be the infallible standard of faith and practice, we must either receive them as such, or, if we would be consistent, disown the writers as imposters" (The Calvinistic and Socinian Systems Examined and Compared, as to Their Moral Tendency, in The Complete Works of the Rev. Andrew Fuller, ed. and rev. Joseph Belcher (1845; repr., Harrisonburg, VA: Sprinkle, 1988), 2:196. Hereafter this collection of Fuller's written corpus is simply cited as Works of the Rev. Andrew Fuller.

${ }^{14}$ For these apologetic treatises, see volume 2 of Works of the Rev. Andrew Fuller. For studies of Fuller's replies to these theological aberrations, see Michael A. G. Haykin, ed., "At the Pure Fountain of Thy Word": Andrew Fuller as an Apologist (Carlisle: Paternoster, 2004). 
from its inception in 1792 till his death in 1815. Moreover, it was his theology that lay at the heart of the missional vision of his close friend William Carey (1761-1834), the Baptist Missionary Society's first missionary appointment. As Harry R. Boer has noted, "Fuller's insistence on the duty of all men everywhere to believe the gospel ... played a determinative role in the crystallization of Carey's missionary vision." ${ }^{\prime 15}$

\section{A Champion of the Reformation}

The earliest references by Fuller to Luther are entries in his diary for June 26 and 28, 1781, when he noted that he had been reading An Ecclesiastical History by the Lutheran historian Johann Lorenz von Mosheim (16931755). On June 26, the Baptist pastor observed that he was "sick in reading so much about monks [and] mendicant friars," and added, "I could have wished the history had more answered to its title - a history of the church; but it seems little else than a history of locusts"! Two days later, though, he was in a better frame of mind after reading Mosheim:

Some sacred delight in reading more of Mosheim on the coming forth of those champions of the Reformation-Luther, Melancthon [sic], Zuinglius, Calvin, \&c., into the field. I think I feel their generous fervour in the cause of God and truth. How were the arms of their hands made strong by the mighty God of Jacob!16

"The cause of God and truth" was a favorite expression of Fuller that summarized what he saw as the calling of every minister: they ought to be zealous for God's glory and his truth. It was thus a high compliment to describe Luther as such.

At the very close of his ministry, in 1814 and 1815, when Fuller came to preach on the book of Revelation, he went so far as to think that the slaying of the two witnesses in Revelation 11 might possibly refer to "the times immediately preceding the Reformation." If this were so, Fuller reasoned, then the resurrection of the witnesses has to do with the raising up of the Reformers:

Whether the "three days and a half" during which the witnesses should lie unburied, denote three years and a half, and refer to a particular period of that duration, or only to a short space of oppression, in allusion to the "three times and a half," as

${ }^{15}$ Harry R. Boer, Pentecost and Missions (Grand Rapids: Eerdmans, 1961), 24. See also John Piper, Andrew Fuller: Holy Faith, Worthy Gospel, World Mission (Wheaton, IL: Crossway, 2016), $13-16$.

${ }^{16}$ Michael D. McMullen and Timothy D. Whelan, eds., The Diary of Andrew Fuller, 17801801, vol. 1 of The Complete Works of Andrew Fuller (Berlin: de Gruyter, 2016), 31. 
being a kind of 1260 years in miniature, I am not able to determine; nor have I seen anything on the subject relating to a particular period which afforded me satisfaction. However this may be, if the slaying of the witnesses refer to the times immediately preceding the Reformation, their resurrection and ascension to heaven must denote the Reformation itself, and the placing, by divine providence, of the parties concerned in it out of the reach of their enemies. The resurrection, as it were, of the Waldenses, the Wickliffites, and other reputed heretics, in the persons of Luther and his contemporaries, with the rapid progress made by them in various nations nearly at the same time, would cause great fear to fall upon their adversaries; and the security in which they were placed by the secession of those nations from the see of Rome was equal to their being taken up to heaven in a cloud, where those who thirsted for their blood could only look after them with malignity and envy. ${ }^{17}$

Here Fuller admitted his inability to find any convincing interpretation of certain elements of Revelation 11, especially the meaning of the "three days and a half" after the two witnesses have been slain and during which they lie unburied (see Rev 11:7-9). ${ }^{18} \mathrm{He}$ was willing, however, to go on record publicly as saying that the passage might have reference to the opposition to the medieval Church of Rome by the Waldensians, the followers of Pierre Valdes (ca.1140-ca.1205), and the "Wickliffites," or Lollards, who adhered to the teaching of John Wycliffe (ca. 1330-1384), and then the "resurrection" of this opposition at the time of the Reformation "in the persons of Luther and his contemporaries." It is noteworthy that Luther's teaching was likened to that of Wycliffe in the early days of the English Reformation. Henry VIII (14911547), for example, described Luther's teaching as "pure Wyclifism."19

This understanding of the continuity of teaching between Luther and such forerunners of the Reformation as the Waldensians and Wycliffe meant that Fuller was not nonplussed by the query—presumably made by Roman Catholics- "Where was your church before Luther?"20 During what Fuller called the "long period of ... domination" ofWestern Europe by the papacy, ${ }^{21}$ the true church was existent, albeit in hiding, only to emerge in full force during the Reformation era, which, for Fuller, like other British Evangelicals of his day, was thus a key event in the history of the church. ${ }^{22}$

${ }^{17}$ Andrew Fuller, Expository Discourses on the Apocalypse, in Works of the Rev. Andrew Fuller, 3:251.

${ }^{18}$ Fuller's mention of "three times and a half" and the 1260 years seems to have in view Daniel 7:25; 12:7 and 11, though Daniel 12:11 speaks of "1290 days." See Fuller, Expository Discourses on the Apocalypse, 244.

${ }^{19}$ Cited by Anthony Kenny, "The Accursed Memory:The Counter-Reformation Reputation of John Wyclif," in Anthony Kenny, ed., Wyclif in His Times (Oxford: Clarendon, 1986), 159.

${ }^{20}$ Fuller, Expository Discourses on the Apocalypse, 258.

${ }^{21}$ Ibid.

${ }^{22}$ Ibid., 243. In his 1791 sermon "Instances, Evil, and Tendency of Delay, in the Concerns 


\section{Imitating Luther}

Fuller also considered Luther's method of preaching as worthy of emulation. In 1802, he cited a general statement by his fellow Baptist Robert Robinson (1735-1790) about the type of preaching that has produced profound moral change in the history of Christianity:

Presumption and despair are the two dangerous extremes to which mankind are prone in religious concerns. Charging home sin precludes the first, proclaiming redemption prevents the last. This has been the method which the Holy Spirit has thought fit to seal and succeed in the hands of his ministers. Wickliffe, Luther, Knox, Latimer, Gilpin, Bunyan, Livingstone, Franck, Blair, Elliot, Edwards, Whitefield, Tennant, and all who have been eminently blessed to the revival of practical godliness, have constantly availed themselves of this method; and, prejudice apart, it is impossible to deny that great and excellent moral effects have followed. ${ }^{23}$

Fuller had long considered Luther's preaching a worthy model. In a sermon that he delivered on October 31, 1787, at the installation of Robert Fawkner as the pastor of Thorn Baptist Church, Bedfordshire-later entitled The Qualifications and Encouragement of a faithful Minister illustrated by the Character and Success of Barnabas ${ }^{24}$-Fuller noted a key principle: "Eminent spirituality in a minister is usually attended with eminent usefulness." 25 After giving a number of biblical examples of men of eminent piety who were instrumental in "great reformation"-men such as Hezekiah, Ezra, and Nehemiah-Fuller commented,

Time would fail me to speak of all the great souls, both inspired and uninspired, whom the King of kings has delighted to honour: of Paul, and Peter, and their companions; of Wickliff, and Luther, and Calvin, and many others at the Reformation; of Elliot, and Edwards, and Brainerd, and Whitefield, and hundreds more

of Religion" (Works of the Rev. Andrew Fuller, 1:147), Fuller referred to the Reformation as "the glorious work of the Reformation."

${ }^{23}$ Andrew Fuller, The Calvinistic and Socinian Systems Examined and Compared, as Their Moral Tendency, in Works of the Rev. Andrew Fuller, 2:121-122. Fuller is citing from a note by Robert Robinson in his translation of Jean Claude, An Essay on the Composition of a Sermon (Cambridge: Francis Hodson, 1779), 2:364.

24 The sermon was first published in 1787: Andrew Fuller and John Ryland, The Qualifications and Encouragement of a Faithful Minister, illustrated by the Character and Success of Barnabas. And, Paul's Charge to the Corinthians respecting their Treatment of Timothy, applied to the Conduct of Churches toward Their Pastors. Being the Substance of Two Discourses, Delivered at The Settlement of The Rev. Mr. Robert Fawkner, in the Pastoral Office, Over the Baptist Church at Thorn, in Bedfordshire, October 31, 1787 (London:Thorn Baptist Church, 1787). It can be conveniently found in Works of the Rev. Andrew Fuller, 1:135-44.

25 Fuller, The Qualifications and Encouragement of a Faithful Minister, in Works of the Rev. Andrew Fuller, 1:143. 
whose names are held in deserved esteem in the church of God. These were men of God; men who had great grace, as well as gifts; whose hearts burned in love to Christ and the souls of men. They looked upon their hearers as their Lord had done upon Jerusalem, and wept over them. In this manner they delivered their messages; "and much people were added unto the Lord. ${ }^{26}$

Here, Fuller urged Fawkner to see Luther, as well as the others that he mentioned, as a man of "great grace," whose love for Christ and whose longing for the conversion of sinners shaped the message he preached. Such a man was akin to "Paul and Peter," and as such a great role model for preaching.

Four years after this sermon at Thorn Baptist Church, Fuller again cited Luther as an example to follow, this time with regard to his courage in the promotion of reform in the sixteenth century. Fuller was preaching on Haggai 1:2 ("Thus speaketh the Lord of hosts, saying, This people say, The time is not come, the time the Lord's house should be built," KJv) at a meeting of the pastors of the Northamptonshire Association on April 27, 1791, in the Baptist church at Clipston, Northamptonshire, and was seeking to encourage his fellow Baptists to think about the possibility of undertaking cross-cultural missions. ${ }^{27}$ This sermon was, in fact, a key step on the road to the formation of the Baptist Missionary Society and the sending of Fuller's close friend William Carey to India. ${ }^{28}$

After sketching the historical context of the verse from Haggai, namely, the refusal of the Israelites to get to work on the rebuilding of the temple after their return from the Babylonian exile, Fuller noted that the main problem which afflicted the Israelites was a "procrastinating spirit." It was not, however, a problem unique to them, but hampered both unbelievers and believers in his own day. With regard to the latter, it prevented them from "undertaking any great or good work for the cause of Christ, or the good of mankind." ${ }^{29}$ Thankfully, Fuller declared in an illustration of his point, Luther was free from this tendency:

${ }^{26}$ Ibid., 143-44.

27 Fuller, "Instances, Evil, and Tendency of Delay, in the Concerns of Religion," in Works of the Rev. Andrew Fuller, 1:145-51. Fuller originally entitled this sermon, The Pernicious Influence of Delay in Religious Concerns.

${ }^{28}$ For more on the historical context and importance of this sermon, see John Sutcliff and Andrew Fuller, The Clipston Sermons: A Key Moment in the History of Christian Missions, introduced by Michael A. G. Haykin, and ed. Michael A. G. Haykin and G. Stephen Weaver (Louisville, KY:The Andrew Fuller Center for Baptist Studies, 2016).

${ }^{29}$ Fuller, "Instances, Evil, and Tendency of Delay, in the Concerns of Religion," 145-46. 
Had Luther and his contemporaries acted upon this principle [of delay], they had never gone about the glorious work of the Reformation. When he saw the abominations of popery, he might have said, These things ought not to be; but what can I do? If the chief priests and rulers in different nations would but unite, something might be effected; but what can I do, an individual, and a poor man? I may render myself an object of persecution, or, which is worse, of universal contempt; and what good end will be answered by it? Had Luther reasoned thus-had he fancied that, because princes and prelates were not the first to engage in the good work, therefore the time was not come to build the house of the Lord-the house of the Lord, for anything he had done, might have lain waste to this day. ${ }^{30}$

Fuller was convinced that the ministry of the Reformers in word and print had been honored by the Spirit of God for the blessing of many in the sixteenth and later centuries. The example of Luther was thus an appropriate one to bring forward to encourage his hearers to break out of the grip of a "procrastinating spirit." As this text reveals, Fuller clearly considered the Reformation as a watershed in the history of Christianity - it was a "glorious work." The rise of what has been termed the modern missionary movement at the end of the eighteenth century - in which Fuller, Carey, and their friends played a critical role-was certainly another. It is fascinating to see these two events linked together in this admonition to take Luther's courage as a model to imitate.

Although it is obvious from these references to Luther that Fuller knew the German Reformer did not accomplish the Reformation by himself, and also that he was not the first to protest against the doctrinal and moral problems of the Church of Rome-Fuller was well aware of medieval forerunners-yet Fuller can use Luther's example to highlight the importance of individual action on the scene of history. In a 1785 tract designed to encourage revival of the Calvinistic Baptist cause in England, which was greatly needed in the late eighteenth century, ${ }^{31}$ Fuller again cited Luther as a model:

We may think the efforts of an individual to be trifling; but, dear brethren, let not this atheistical spirit prevail over us. It is the same spawn with that cast forth in the days of Job, when they asked concerning the Almighty, "What profit shall we have if we pray unto him?" [Job 21:15b]. At this rate Abraham might have forborne interceding for Sodom, and Daniel for his brethren of the captivity. James also must be

30 Ibid., 147.

${ }^{31}$ For details of this declension and subsequent revival of the English Calvinistic Baptist community, see Michael A. G. Haykin, One Heart and One Soul: Fohn Sutcliff of Olney, His Friends, and His Times (Darlington, England: Evangelical Press, 1994), and idem, Ardent love to Fesus: English Baptists and the Experience of Revival in the Long Eighteenth Century (Bridgend: Bryntirion, 2013). 
mistaken in saying that the prayer of a single, individual righteous man availeth much. Ah, brethren, this spirit is not from above, but cometh of an evil heart of unbelief departing from the living God! Have done with that bastard humility, that teaches you such a sort of thinking low of your own prayers and exertions for God as to make you decline them, or at least to be slack or indifferent in them! Great things frequently rise from small beginnings. Some of the greatest good that has ever been done in the world has been set a going by the efforts of an individual. Witness the Christianizing of a great part of the heathen world by the labours of a Paul, and the glorious reformation from popery began by the struggles of a Luther. ${ }^{32}$

Although the bulk of examples cited in this text have to do with prayerAbraham praying for Sodom (in Gen 18), Daniel for the Jewish people in exile (in Dan 9), James's comment about the impact of the prayers of a righteous person (Jas 5:16) - Fuller does not seem to be thinking so much of Luther as a model of prayer as an example of the impact of an individual Christian for good.

\section{The Matter of Justification}

From what we know of Fuller's library, there is no indication that he actually owned a book by Luther, ${ }^{33}$ and so it is not surprising that his references to Luther do not include an actual citation from any of the Reformer's works. What is fascinating, though, is that while the doctrine of justification had been a central part of the way Luther was remembered in the English Puritan and Evangelical traditions, Fuller refers to Luther only once with regard to justification.

That citation occurs at the close of an undated piece that Fuller wrote on justification and imputed righteousness, probably for one of the theological magazines to which he regularly contributed. ${ }^{34}$ Fuller has been arguing that the picture of the church throughout the New Testament is uniformly one that is "composed of such characters as, renouncing all dependence upon their own righteousness, rely only upon the righteousness of Christ for acceptance with God." 35 But what of the letter of James, "which appears to affirm that a man is justified 'by works, and not by faith only"'? Fuller argued that James is actually using the term "justification" to refer to God's

\footnotetext{
${ }^{32}$ Andrew Fuller, Causes of Declension in Religion, and Means of Revival, in Works of the Rev. Andrew Fuller, 3:322.

${ }^{33}$ For a list of the books in Fuller's library ca. 1798, see Timothy D. Whelan, "Appendix A: Books in Fuller's Library, 1798," in The Diary of Andrew Fuller, 1780-1801, ed. McMullen and Whelan, 215-36.

${ }^{34}$ Andrew Fuller, "Justification: The Doctrine of Imputed Righteousness," in Works of the Rev. Andrew Fuller, 3:709-12.

${ }^{35}$ Ibid., 711-12.
} 
approval of an individual as being a genuine believer:

Paul discourses on the justification of the ungodly, or of sinners being accepted of God, which is by faith in the righteousness of Christ, without works; James on the justification of the godly, or of a saint being approved of God, and which is by works. Abraham is said to have been justified by faith, when he first believed the promise, prior to his circumcision; but by works, many years after it, his faith was made manifest, when he offered Isaac his son upon the altar. The one therefore relates to his acceptance with God as a sinner, the other to his being approved of God as a saint. Both together completed his character. "He believed, and it was accounted unto him for righteousness" [Romans 4:3]; he obeyed, and was "called the friend of God" [James 2:23]. ${ }^{36}$

Seemingly oblivious to Luther's questions about the canonicity of James, Fuller then noted regarding justification,

We ... see the justice with which divines have insisted on the importance of this great article of faith. It was with good reason that Luther, in particular, considered it as a kind of corner-stone in the Reformation. Those reformed communities, whether national or congregational, which have relinquished this principle in their confessions of faith, or which, retaining it in their confessions, yet renounce or neglect it in their ordinary ministrations, have with it lost the spirit and power of true religion. ${ }^{37}$

Here Fuller rightly recalls the centrality of justification for Luther, though, as noted, the Baptist author does not appear to have learned it directly from the German Reformer. When Fuller does cite authorities for his Reformation understanding of justification, it is Puritan authors like John Owen (16161683), ${ }^{38}$ or Evangelical pioneers like his main theological mentor, Jonathan Edwards. ${ }^{39}$ But Fuller's enormous respect for the Reformer ensured that the Baptist's heirs in the nineteenth century, and they were many and on both sides of the Atlantic, would continue to keep Luther in their pantheon of heroes. And this, in turn, entailed the distinct possibility that these Fullerite Baptists would take up his key books and read him.

${ }^{36}$ Ibid. Cf. Fuller's similar argument in his sermon "Justification," in Works of the Rev. Andrew Fuller, 1:288.

${ }^{37}$ Fuller, "Justification: The Doctrine of Imputed Righteousness," 712.

${ }^{38}$ For example, see Andrew Fuller, "Defence of the Doctrine of Imputed Righteousness," in Works of the Rev. Andrew Fuller, 3:713.

${ }^{39}$ See the very helpful discussion of Fuller's indebtedness to Edwards regarding the doctrine of justification in Chun, Legacy of fonathan Edwards in the Theology of Andrew Fuller, 183-208. In recent days, questions have been raised regarding Edwards's view of justification, as to whether or not it involved a departure from the Reformation understanding of this doctrine. See the helpful studies in Josh Moody, fonathan Edwards and Fustification (Wheaton, IL: Crossway, 2012). Also see Craig Biehl, The Infinite Merit of Christ: The Glory of Christ's Obedience in the Theology of fonathan Edwards (Jackson, MS: Reformed Academic Press, 2009). 


\section{NEW FROM ZONDERVAN ACADEMIC}

\section{The Five Solas Series}

Matthew Barrett, General Editor

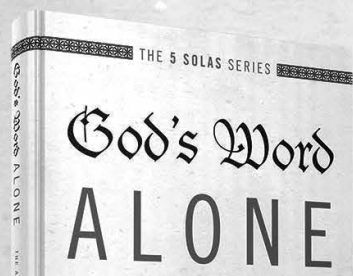

THE AUTHORITY

OF SCRIPTURE

What the Reformers Taught .... and Why it Still Matters

MATTHEW BARRETT

BY R. ALBERT MOHLER JR.
Faith Alone-The Doctrine of Justification

Thomas R. Schreiner | 9780310515784 | \$19.99

Christ Alone-The Uniqueness of Jesus as Savior Stephen Wellum | 9780310515746 | \$24.99

God's Word Alone-The Authority of Scripture Matthew Barrett | 9780310515722 | \$24.99

God's Glory Alone-The Majestic Heart of Christian Faith and Life

David VanDrunen | 9780310515807 | \$16.99

God's Grace Alone-Salvation as a Gift of God Carl R. Trueman | 9780310515760 | \$21.99

Historians and theologians alike have long recognized that at the heart of the sixteenth-century Protestant Reformation were five declarations that distinguished the movement from other expressions of the Christian faith.

The Five Solas series will help you understand the historical and biblical context of the five solas and how to live out the relevance of Reformation theology today. 


\title{
Luther and the Turks
}

\section{HANS SCHWARZ}

\begin{abstract}
Confronted with the military advance of the Turkish Ottoman Empire against the Holy Roman Empire, including the siege of Vienna, Martin Luther wrote several treatises on the Turks. Luther rejected the idea of a war in the name of religion against the Ottoman onslaught, seeing instead the defense of the Holy Roman Empire as the duty of the Emperor. Luther understood the Turkish threat as God's punishment for the laxity of Christians and so called for repentance and a return to the gospel. Luther wanted the Christians to have firsthand information about Islam and promoted a translation of the Qur'an in German against many obstacles. The Protestant church in Germany is very cautious about defining a present-day application of Luther's approach.
\end{abstract}

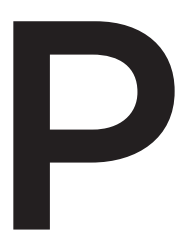

erhaps it is because of the guilty conscience Christians have over their mistreatment of the Jews throughout the centuries in word and deed that Luther's writings concerning the Jews are frequently discussed. All of these writings have been translated into English. The same is not true concerning his writings about the Turks. ${ }^{1}$ None of them are available in English, and in German literature they are hardly mentioned. This may be due to the fact that there are now more than three million people with Turkish roots living in Germany.

1 In the writings of Martin Luther, the term Turks would today in many ways be equivalent to the term Muslims. It is only when this fact is grasped that one sees how contemporary and significant Luther's writings on the subject really are. Yes, Luther was a man of his time, and some of his ideas are quite primitive, but what he said is nevertheless important for today's dialog on the subject. 
This lacuna is amazing, because just thirty years before Martin Luther was born Constantinople was conquered by the Turks (1453). One could even say that without the Turkish, or rather the Ottoman, army pounding every now and then on the eastern border of the Holy Roman Empire, Luther's Reformation would have been doomed. Each time Emperor CharlesV (1500-1558) wanted to clamp down on the Reformation, the Ottoman military would advance westward, making him more conciliatory toward the Protestant princes because he needed their support against this threat.

After the devastating defeat of the Hungarian kingdom by the Ottoman army under Suleiman the Magnificent (1494-1566) at the battle of Mohács in 1526, central Europe was under the threat of being conquered by the Turks. The first Turkish siege of Vienna began in 1529. It is not surprising that Pope Leo X in his bull Exsurge Domine rejected Luther's idea that "to wage war against the Turks and fight them is to resist God, who is using them to punish us for our sins," wanting instead to launch a crusade against the Turkish threat. But Luther wrote in a letter to Georg Spalatin (1484-1545), the counselor of his elector, Frederick the Wise, that on a biblical basis he could not advocate war against the Turks. ${ }^{3}$ As Luther explained in his commentary on his Ninety-Five Theses, the Turks are God's rod with whom God punishes us for our sins. ${ }^{4}$ To wage war against this rod would amount to resisting God's punishment. Though he realistically saw the danger of the expansionist policy of the Ottoman Empire, Luther was by no means a crusader, and he certainly did not want a war conducted by a religious leadership, since for Luther religious concerns and worldly force should never be mixed.

Other important contemporaries of Luther also rejected the idea of a crusade against the Turks. The humanist scholar Erasmus of Rotterdam (ca. 1469-1536) was convinced that it was important to save as many Turks as possible, not to kill them. ${ }^{5}$ He suggested that the most effective means against them would be for them to see in Christians a resemblance of the teachings of Christ. As far as Erasmus was concerned, if the Turks did not perceive Christ in Christian demeanor, then Christians would more easily

2 "Leo X: Bannandrohungsbulle 'Exsurge Domine,"” in Peter Fabisch and Erwin Iserloh, eds., Dokumente zur Causa Lutheri (1517-1521), part 2 (Münster: Aschendorff, 1991), 385.

3 Martin Luther to Georg Spalatin (December 21, 1518), letter no. 125, in WA BR 1:282 (WA = Martin Luther, D. Martin LutherWerke, 120 vols. [Weimar, 1883-2009] and BR= Briefe).

4 Martin Luther, Resolutiones disputationum de indulgentiarum virtute (1518), in WA $1: 535.35-39$.

5 Cf. for the following, Rudolf Mau, "Luthers Stellung zu den Türken," in Helmar Junghans, ed., Leben und Werk Martin Luthers von 1526 bis 1546 (Göttingen: Vandenhoeck \& Ruprecht, 1983), 1:647. 
become Turks than Turks would become Christians. Ulrich von Hutten (1488-1523), another well-known humanist, also rejected the idea of a crusade. He asserted that Rome should not command wars but pray and proclaim the gospel. He said, however, that the princes under the leadership of the emperor should defend us against the Turks and bring honor to the German name. These other opinions show that Luther was not the only one who rejected the idea of a crusade against the Turks. But what did Luther actually write about the Turks?

\section{Luther's Writings on the Turks}

Luther's treatise OnWar Against the Turks of 1528 shows that Luther was not a pacifist. He refers to Pope Leo's bull and explains, "To fight against the Turks is as much as to resist God who punishes our sins with such a rod." Luther always perceived the Turkish threat as God's punishment for the sinfulness of his own German people. Therefore, Luther emphasizes over and over again that the only way to remove the rod from God's hand is to do penance and to return to the Christian faith. When German politicians today are confronted by German citizens who say, out of an obvious fear, that there are too many Muslims in Germany, the politicians say that Germans should express their Christian faith more freely. At the same time, the church in Germany remains silent on the issue and does not say Christians should confess their faith more clearly. Instead, the church demands toleration of Muslims and dialogue as a genuine task of Reformation theology. The leading motif in church and society is therefore not of penance, which would lead to the gospel, but law: righteousness by works. Yet for Luther, penance was important, and subsequently prayer to God for mercy, since it is God who is ultimately the Lord of history, not us.

Luther emphasizes in his treatise that it is not the task of the church but of the secular authorities to rally and wage war against the Turks. Looking back on history, he reflects that "as Christians and in the name of Christ there has never been a war won against the Turks." "Yet everyone should remember "to what he has been called by God and faithfully serve in that office." Since the Turks have no right to start a war and to attack other countries that are not theirs, Luther concludes that God punishes the world with the Turks, at whose hands occasionally even pious people will have to

\footnotetext{
6 Martin Luther, Vom Krieg wider die Türken, in WA 30/2:108.20-21.

7 Ibid., in WA 30/2:113.2.

8 Ibid., in WA 30/2:112.15-16.
} 
suffer. For Luther it is especially evil that the Turks restrict the freedom of the Christian faith. Though some Christians even at that time imagined that the Turks allowed everybody under their rule to believe what they want as long as the Turks could exercise their worldly authority, Luther contends that the Turks do not allow Christians to gather in public and that nobody is allowed to openly confess Christ or preach or teach anything against Mohammed: "But what kind of freedom of faith is this if one is not allowed to preach or confess Christ?" Luther suggests that we need only look at the situation of Christians in Turkey to see that there everything is going downhill and is becoming Islamic.

Luther knows the Qur'an from his own reading, ${ }^{10}$ and he explains that in the Qur'an Mary and Christ are highly praised and depicted to be without sin. Yet the Qur'an denies that Christ is the true Savior of the world and instead states that Jesus is like any other prophet. In contrast, Mohammed praises himself highly and shows how he has spoken with God and the angels. While according to Mohammed, the office of Christ has already been completed and Mohammed was commanded "to convert the world to his faith, and if people are unwilling to surrender, to conquer them with the sword or punish them," "l1 Luther contends that the Islamic faith is a mixture of religions "pasted together from the faith of Jews, Christians, and pagans." 12 Luther notes especially that the Qur'an not only destroys the Christian faith but also the secular authority, since Mohammed commands Muslims to rule with the sword. The most important work advocated in the Qur'an is therefore to take up the sword. According to Luther, Muslims learn "that in their law it is commanded as a good divine work that they rob, murder, and devour further and further areas and destroy them" ${ }^{13}$ pious Christians, in contrast, delight in neither murder nor in the death of their enemies. $\mathrm{He}$ says therefore that the Turks cannot be a part of the divinely ordered authority which safeguards peace and protects the pious by punishing evildoers. Instead, they are God's rod of wrath and punishment for the unbelieving world. Finally, Luther is also critical of the Qur'an for allowing polygamy and treating women as property and not as partners of men. Luther strictly distinguishes the three basic orders of God as the religious, the political, and

9 Ibid., in WA 30/2:120.33-34.

${ }^{10}$ Cf. Luther, Einleitung zur Verlegung des Alcoran, in WA 53:272.16ff. Having vehemently advocated a German edition of the Qur'an, he wrote a preface to this edition in 1543; see Mau, "Luthers Stellung zu den Türken," 661.

${ }^{11}$ Luther, Vom Krieg wider die Türken, in WA 30/2:122.10ff.

12 Ibid., in WA 30/2:122.29-30.

13 Ibid., in WA 30/2:123.32-33. 
the economic, which cannot be mixed together. In the Qur'an, however, these orders are not distinguished from each other, so that the political order serves the religious to wage war in the name of Allah.

Luther asks, What should Christians do against this obvious threat? Since it expresses God's wrath, Christians must either suffer or fight the Turks with penance and prayer to drive them away. As for the secular authority, if the Turks attack the subjects of the emperor and his empire, it is the duty of the emperor "as an authority instituted by God to defend his people." ${ }^{14}$ Under the emperor's command and in his name one may wage war against the Turks, and whoever joins in is obedient to God. Yet Luther says that one should not fight the Turks for honor, nor to win goods and land, nor out of wrath and vengeance, but only to protect one's subjects. Luther also rejects the idea of a war of religion. He writes: "Let the Turks believe and live as they will just as one lets the papacy and other false Christians live. This sword of the emperor has nothing to do with faith."15 One should not wage war against the Turks because of their wrong faith and way of life, but only because of their murderous and destructive activities. The same holds true with regard to the pope, whom Luther often sees in parallel to the Turks, since both the pope and the Turks endanger the Christian faith.

Luther's treatise was published in April 1529, and in the same year it was reprinted seven times, which shows the immense interest in this publication at that time. This need not surprise us, since there was hardly any precise information available about the Turks and their faith, a fact about which Luther also complained. Luther therefore had a treatise published in Wittenberg entitled Libellus de ritu et moribus Turcorum (A Writing about the Rites and Customs of the Turks, 1530), for which he provided a preface. This treatise had been written by Gregorius of Hungary (1422-1502), a Dominican monk from Transylvanian Saxony, present-day Romania, who had been in Turkish captivity as a slave for several decades and had gotten to know quite well the conditions that existed under Turkish rule. Luther mentions in this preface that the ceremonies and customs of the Turks are more convincing than those of the Christians: "If any [Christians] would stay for only three days under the Turks, probably no one would remain in his or her Christian faith."16

Already prior to that Luther had taken up his pen on October 28, 1529, writing $A$ Sermon against the Turks. This sermon was occasioned by the

\footnotetext{
${ }^{14}$ Ibid., in WA 30/2:129.19-20.

${ }^{15}$ Ibid., in WA 30/2:131.6-9.

${ }^{16}$ Martin Luther, "Vorwort zu dem Libellus de ritu et moribus Turcorum" (1530), in WA 30/2:206.16-17.
} 
advance of the Turks against the city of Vienna. But then they surprisingly withdrew. Luther interprets the threat by the Turks as a sign of the end times. He refers to the book of Daniel with the pronouncements of the four empires (Dan 2) and the four beasts (Dan 7) and assumes that the Turks are part of the last empire and the fourth beast. He even suggests that their advance is God's punishment, an attack of Satan, in this final eschatological battle. "He thus could lump the papacy and Turks together: 'The pope is the spirit of the antichrist, and the Turk is the flesh of the antichrist. The two help each other to strangle us, the latter with body and sword, the former with doctrine and spirit."' ${ }^{17} \mathrm{He}$ thus sees the pope and the Turks as the tyrants foretold for the end time.

According to Luther, the Turks do not distinguish between nominal and real Christians because they are the enemy of the name of Christ. Luther thought that since we live in the end times heaven will dethrone the Turkish Empire and thereafter nothing dangerous will come. The Turks' position as an enemy of God, as a blasphemer and persecutor of Christ and of his saints with the sword and fighting, will come to an end. "We can surely say that judgment day must be pounding on the door." ${ }^{\text {18 }}$ Even in this end-time situation Luther does not call for a crusade against the Ottoman Empire but enjoins everyone to diligently follow Christ and be ready to suffer under its rule. One must be obedient to secular authority and protect in its name the country and the people, both women and children. Since the attacks of the Turks are directed against Christ, one fights against the enemy of God, even against the devil himself. In the battle against them one need not be afraid that one might kill innocent people, because all who fight in the Turkish army, including the Christians that fight in it, are obedient to the devil. Luther sees here an apocalyptic battle between the Christians with God and the Turks with the devil. Nevertheless, he does not advocate a crusade in the name of Christ. For Luther one can only properly fight under the secular authority, not as a Christian but as a secular subject, and only if the Turks initiate war. A pre-emptive strike against the enemy is never an option for Luther.

But Luther does not lambast the Turks. He even has some good things to say about them. Their spiritual leaders, for instance, lead an earnest and rigorous life. In their mosques there is silence and good demeanor, and one prays with beautiful external gestures that can hardly be found in Christian churches. The Turks

${ }^{17}$ So Bernhard Lohse, Martin Luther's Theology: Its Historical and Systematic Development, trans. and ed. Roy A. Harrisville (Minneapolis: Fortress, 1999), 334, WA Tischreden 1, no. 330.

${ }^{18}$ Martin Luther, Heerpredigt wider den Türken, in WA 30/2:171.20-21. 
do not drink wine, do not guzzle and become gluttons, as we do. ... [They] do not swear and curse, have great and proper obedience, and propriety against their emperor and lords, and have their governments organized in such a manner as we would love to have in our German territories." 19

Since they have become powerful and won many victories against the Christians, they think that their faith and demeanor is pleasing to God. Therefore, it is impossible to convert just one single Turk. As with the pope, Luther sees the Turks as immensely self-righteous: if one were a prisoner under the Turks and had to serve them, one should do it without reservation and as long as it is useful for the new lord and his property. "But if they should force us to fight against Christians, we should not obey but rather suffer everything they would do, even death." ${ }^{20}$ One must not betray one's Christian faith.

Luther's Sermon is a call to utmost readiness and determination in resisting the Turks. He approves of material sacrifices, including a tax levied on the people, for fighting the Turks and also defense even at the cost of one's own life. One must also hold fast to one's Christian faith. Luther does not expect success against the Turks, and he is also not convinced of victory. Yet he is sure that it is the final eschatological battle and therefore that the empire of the Turks will soon come to naught. At the same time Luther is convinced that the Turks are God's rod levied by God for our sins, both on Christians and non-Christians, if we do not change our ways and desist from persecuting and blaspheming the gospel. Luther is undecided whether the Turks are just God's punishment or are already the foreboding judgment day. He comforts himself with the assurance that whoever is a Christian and has changed his ways can suffer and then enter eternal bliss.

Luther had heard that the Turks had devastated a large portion of Austria and killed or taken captive more than one hundred thousand people. When Emperor Charles V asked the Protestant estates for help against the Turks, Landgrave Philip of Hesse (1504-1567) wrote to Luther, saying that if Luther were asked by his elector for advice he should suggest that the elector put pressure on the emperor. ${ }^{21}$ Philip's idea was that help against the Turks should only be granted by the Protestant estates if the emperor provided a satisfactory solution for the Protestants so that they may freely exercise their faith. Luther, however, did not want to mingle religious concerns with political ones and therefore responded to the landgrave evasively, saying

${ }^{19}$ Ibid., in WA 30/2:189.27-190.1.

${ }^{20}$ Ibid., in WA 30/2:196.22ff.

${ }^{21}$ Cf. letter of Landgrave Philip of Hesse to Luther of December 9, 1529 (no. 1503), and Luther's answer of December 16, 1529 (no. 1507), in WA BR 5:203-4. 
that so far the elector had neither consulted him nor informed him about his plans.

In August 1541 Suleiman II again invaded Hungary. After expelling the Austrian occupation forces, he put the country under Ottoman administration. By the end of the month Luther had heard of a large Turkish army moving westward. There was alarm in Germany, and the elector John Frederick of Saxony (1503-1559) was afraid that the Turks would not only move toward Vienna and take all of Austria but also devastate Germany. Therefore, he turned to Luther and Johannes Bugenhagen (1485-1558), pastor of Saint Mary's church in Wittenberg and organizer of the Lutheran church in Northern Germany and Scandinavia, asking that they summon the pastors to preach repentance.

In October 1541, when some thought that Western Christendom was doomed, Luther wrote an Appeal for Prayer Against the Turks. Again he does not deviate from his conviction that as a Christian one should neither despair nor simply trust one's own might; instead, one should fear God and at the same time trust in God's goodness. On the positive side, Luther suggests that the Turks teach us to fear God so that we learn again how to pray. The first task of preaching is therefore to call us to recognize our own sinfulness and to accept that God punishes us, but also to trust him with our whole heart, to pray, and to call on him for all needs. The second task of preaching is to call us to return to God with true prayer that we might obtain good fortune and victory. We should not trust in our own righteousness but in God's grace. Since the Turks want to put Mohammed in the place of Jesus Christ and therefore blaspheme God, saying, "He is no true God and our Mohammed is higher and better than he," we may ask God to sanctify his name. ${ }^{22}$ According to Luther, judgment day is not far away, and therefore both the Turks and the pope will soon come to their end. We can confidently resist and pray God that he may give us his grace "to punish both the pope and Mohammed together with their devils." ${ }^{23}$

Which points are still of significance for us today in Luther's writings against the Turks? First, we must note that during Luther's time a different nomenclature was used. One did not use the terms Islam and Muslims but talked about "the Turk" or "the Turks" and "Mohammedans," or simply "pagans" or "heretics." The norm for Luther, as well as for the other Reformers such as Calvin or Zwingli, was the Christian faith. Since this newly won

\footnotetext{
${ }^{22}$ Martin Luther, Vermahnung zum Gebet wider den Türken, in WA 51:610.22.

${ }^{23}$ Martin Luther, Verlegung des Alcoran Bruder Richardi, Prediger Ordens, Verdeutscht und herausgegeben, 1542, in WA 53:396.28-29.
} 
faith was threatened by both the pope and the Turks, the two were seen in parallel. Moreover, Luther and the other Reformers often perceived themselves as living in the end time and therefore interpreted enemies of the gospel in apocalyptic terms, drawing on the biblical books of Daniel and Revelation. Much of this looks and sounds very distant to us. But there are other points which merit more serious consideration.

First of all, Luther points out the strict distinction between the spiritual/ ecclesial authority and the worldly authority, a distinction that is essential for the Christian Protestant worldview, but not for the Turkish and Islamic understanding. While the first president of present-day Turkey, Mustafa Kemal Ataturk (1881-1938), established a policy of state secularism, with a constitution that separated the government from religion, there is considerable pressure to end the separation of religion and politics. The emancipation of secular politics from religion seems to go against the grain of Islamic thinking, as Luther perceptively noted. Then Luther interprets the advancement of the Turks as a spiritual challenge for the Christians first to do penance and then to clearly confess their Christian faith. Many Christians today are very timid when it comes to standing up for their Christian convictions, since they do not want to offend anybody. But is our faith really just a private affair? Luther further notices that the Turks regard all Western people as Christians regardless of what their actual religious persuasion may be. Since for most Muslims there exist only Muslims and nonbelievers, regardless of what the actual religious conviction of those who are not Muslims may be, it is still difficult today for Muslims to understand that not all Westerners are Christians. For them the terms are usually synonymous. For Luther it is also clear that under Turkish authority the Christian faith would be curtailed as a formative power. We can see this today in the original Christian heartlands of Northern Africa (home of Augustine and Athanasius) and Palestine and the Near East (home of Paul and John of Damascus), where Christians have been reduced to a small minority. Finally, Luther is convinced that the secular authority must defend its citizens against the Turkish expansionist attempts. All citizens must join in this defense. Even though Luther's mind was occasionally occupied with the end time, for him there was reason for neither panic nor optimism. He was convinced that we must trust God because whatever may come, God's cause will be victorious in the end. Today, we should also live with the conviction that with God's providence everything will turn out all right. Although uncertainty with regard to Muslim extremists still looms, Christians derive their confidence from God's protective power, and they can have the assurance that God will win the final victory in the end. 
Since for Luther and the people of his age Islam consisted of wrong teachings and of heretical assertions, Luther was convinced that Christians must ascertain what they believe to be able to defend their faith. Many Muslims still today believe uncritically the assertions of the Qur'an regarding the principal figures of the Christian faith, including Jesus, Abraham, and Mary, and then claim that the Christians have falsified these assertions. Therefore, it is still important that Christians know their Bible and be able to defend its claims, not contemptuously but with historically informed arguments. It is important for Christians to be religiously literate to defend their own faith. Luther demanded that Christians be religiously literate, and he himself contributed to this end. This was no small task, since publications that were considered heretical were traditionally committed to the flames. The writings of Christian theologians who were condemned as heretics, such as Arius and Pelagius, did not survive. We only know them from the quotations of their orthodox opponents. Even some of Luther's books were burned, and he himself threw into a bonfire the papal bull Exsurge Domine, which threatened him with excommunication, together with the papal decrees known collectively as the Canon Law of the Roman Church. He had made prior preparations to do this, and on December 10, 1520, a crowd of students and townspeople of Wittenberg witnessed the event. ${ }^{24}$ On the other hand, Luther went in the other direction with the Qur'an and tried hard to provide firsthand information about the teachings of Islam.

\section{Luther's Concern for Religious Literacy}

Luther was convinced that the Turks would threaten Christians not only because of their military power but also because of their doctrine and way of life. Therefore, he regarded it necessary that one should be literate regarding Islam. This was not easy, however, because at that time there was no easy access to a Latin translation of the Qur'an, not to mention a German version, which did not exist. It was only in February 1542 that Luther was able to acquire a complete Latin version of the Qur'an. Prior to that, he had to rely on secondary literature such as the Confutatio Alcorani by the Dominican monk Ricoldus de Montecrucis (ca. 1242-1320), who had traveled all the way to Baghdad and learned the Arabic language, since he intended to convert Nestorian Christians to Catholicism. (Nestorius [ca. 386-450],

\footnotetext{
${ }^{24}$ For more information, see Scott H. Hendrix, Martin Luther: Visionary Reformer (New Haven:Yale University Press, 2015), 98.
} 
the one-time archbishop of Constantinople, held that Christ had two separate natures, one divine and one human, and that Mary only gave birth to Christ, and not to God, which implied for many that Nestorius's teaching was heretical, since he did not believe that Christ was truly God.) In the end, Ricoldus's mission failed, and he returned to his native Florence, Italy. He did, however, write a treatise on the Qur'an around 1300. Luther used it and thought at first that it was overly negative, as he was convinced that it would damage the cause more than help it if only negative things were written about Islam and the praiseworthy things suppressed. After he had actually read the Qur'an, however, he realized that it was much worse than he had first thought, so he published a German translation of Ricoldus's Confutatio in 1542 with his own introduction. He cut out much of Ricoldus's tedious exposition and offered a rather free translation of the rest. He highlighted internal contradictions in the Qur'an and pointed to assertions that stood in opposition to the Old and New Testaments. Luther admits in his introduction that initially he thought that Ricoldus's refutation of the Qur'an was built on lies and that Ricoldus was trying to put the pope in the best possible light, but that after he had read the Qur'an in Latin, he realized that this refutation was by no means a fabrication but a proper description of the Qur'an. Since there was no better information about Islam available at the time, Luther translated Ricoldus's refutation of Islam so that, on the one hand, what he called "the horrible faith advocated by Mohammed" could be revealed and, on the other hand, the Christian faith could be strengthened. Luther's intention in translating the Confutatio Alcorani was not to convert the Turks, something that Ricoldus had had in mind, but to strengthen the Christian faith. Luther regarded such a strengthening of the Christian's faith necessary so that the Christian could combat the Turks, and, if captive under the Turks, defend one's beliefs against a wrong faith.

Since the Confutatio was secondhand information, Luther was still interested in providing exact knowledge of the Qur'an itself. Therefore, he was engaged in providing a reliable edition of the Qur'an so that everyone could have information about that religion. As mentioned previously, this position was rather revolutionary. Since Christians considered Islam to be a heresy, the Qur'an was also destined to the flames. For instance, in 1530 the first Latin edition of the Qur'an published in Venice, Italy, was consigned to the flames by papal command. ${ }^{25}$ In Protestant Basel, Switzerland, the printer Heinrich Petri (1508-1579) attempted in 1536 to publish a Latin translation of the Qur'an. But this attempt was put to nought by an injunction of the

${ }^{25}$ Cf. the more extensive information by Mau, "Luthers Stellung zu den Türken,” 660-61. 
city council. In 1542 the Swiss orientalist, publisher, and linguist Theodor Bibliander (1509-1564) in Zurich tried to provide a reliable Latin text of the Qur'an in which he compared the Latin and Arab versions of the Qur'an. The first German translation of the Qur'an was published finally in 1616 by the Lutheran theologian Salomon Schweigger (1551-1622), a translation from the Italian which, however, was based on Bibliander's Latin text. A famous printer in Basel, Johannes Oporinus, likely assuming that a preface by Philip Melanchthon would enable this edition to pass the censorship test, had set the text for printing when the city council discovered his project. The city council confiscated the whole edition, called the printer to task, and even arrested and held held him for a while in prison.

The situation changed when Luther vehemently interceded, and this in itself was a part of a process. Once the whole edition had been confiscated by the city council, Oporin turned to the well-known theologian Martin Bucer (1491-1551), who had introduced the Reformation in the city of Strasbourg, for help. Bucer in turn called on Landgrave Philip of Hesse and asked that he and the Saxon elector Johann Frederick intercede with the city council on behalf of Oporin. The elector then asked Luther to write to the city council. In a letter of October 27, 1542, to the city council, Luther emphasized

that nothing more negative could be done to Mohammed or the Turks with all the weapons in the world, and no bigger damage than if one would bring the Qur'an into the daylight for the Christians so that they could see what a horrible book the Qur'an is. ${ }^{26}$

Pastors too could ascertain their own faith and encourage their people to fight forcefully for pure Christian doctrine. Luther also emphasized that the Qur'an would have been published in Wittenberg long ago if the conditions for it had been right. If the city council of Basel were not willing to have its injunction lifted, Luther would ask Wittenberg to take over the whole of Operin's edition "at its own risk." This way the printer would not incur any financial loss and there would also be no damage to the Christian church.

The city council of Basel agreed to Luther's suggestion, but with the stipulation that the name of the printer and Basel as the place of printing not appear in the printed version, and also that the Qur'an would not be sold in Basel. In 1543 the whole publication process was finished. Luther explained in his preface that since the beginning of the church the true doctrine of God has been flawed by the devil in many ways. ${ }^{27}$ Yet one must

\footnotetext{
${ }^{26}$ Martin Luther, letter no. 3802, in WA BR 10:162.32-36.

${ }^{27}$ Cf. for the following WA 53:569-72.
} 
know this kind of attack to refute it. Just as the apostles refuted the errors of the pagans, Luther suggested that now the church must refute the errors of the enemies of the gospel. He stated that Mohammed and the Turks are in line with the enemies of the gospel. One need not be afraid of the Qur'an, because everybody can see plainly the untruth of its doctrines and therefore be strengthened in the faith.

In the disputation with the Turks - and Islam represented by them-it was important for Luther that this threat to the Christian faith not be attacked in an unfair way. In his defense of the Christian faith against Islam it was clear to Luther that there cannot be two different versions of faith given by God. Since the Christian and Islamic versions were irreconcilable, only one could be from God, and the other must be from human beings or from an anti-God, meaning the devil. Luther hoped to strengthen the church and Christians against the Muslim threat through his writings and the publication of the Qur'an. This was even more necessary, since for Luther it was evident that he was living in the apocalyptic end-time in which Christians were engaged in the final battle between the forces of darkness, represented by the Turks and the pope, who wanted to devour Christians and their faith, and the forces of light, represented by God and the Christian church. But Luther was certain that it would be God who would stem the tide of evil and win the final victory.

\section{A Mixed Reception}

It is not without significance that the Conference on the Issues of Islam of the Protestant Church in Germany (Konferenz für Islamfragen der Evangelischen Kirche in Deutschland, EKD) issued in May 2016 a discussion paper (Impulspapier) with the title Reformation and Islam. This paper dealt with Luther and the Turks, the Lutheran Confessions, and the Reformed tradition and concluded that the church faced the task of establishing a new theological relationship with Islam. The paper states that today we cannot simply transfer the position of the Reformation into the present. Since the Bible itself is the result of a process of tradition, "the biblical text cannot be understood as the immediate 'word of God' the same way it was by the Reformers." 28 This means that the Reformation standard of Scripture alone needs to be reinterpreted. In another place, the paper says, "The challenge consists in talking about Christ in such a way that the faith of others is not devalued or declared untrue. As with Christians belonging to Christ is the

${ }^{28}$ Reformation und Islam (Hannover: Evangelische Kirche in Deutschland, 2016), 24. 
sole comfort in life and death, so it is also with the specific faith for adherents of other religions." ${ }^{29}$ Thus the concept of Christ alone has been reinterpreted considerably. One wonders what Karl Barth would have said, especially in light of the Barmen Declaration. But, of course, one could say that Barth lived in a bygone age. The same reinterpretation occurs with the other Reformation trademarks, faith alone and grace alone.

The paper concludes, "Since the Christian faith is an individual certainty, it cannot be responsibly represented without acknowledging and strengthening the right of divergent religious convictions and thereby the right of religious pluralism." ${ }^{30}$ Luther always emphasized that faith is a personal matter and that we must be able to exercise that faith freely. This implied that there are other religious convictions besides one's own. But Luther himself would have never dreamed of "strengthening the right of divergent religious convictions." Yet that is exactly what is occurring in Germany today. A Lutheran bishop volunteers to become a board member of a future Islamic center, and the EKD advocates Germany-wide Islamic religious instruction in schools, while in some states in Germany, Protestant religious instruction is no longer offered in public schools. ${ }^{31}$ How far away from the Reformation can one get?

Luther would have no problem with the statement in Reformation and Islam that "at present and in the future it is important to treat the heritage of the past in such a way that the encounter with others is not hindered by this heritage but is enabled and furthered." ${ }^{32}$ As was stated earlier, Luther was not a crusader. His intention was never to wage a religious war. Even to resist the emperor when the latter wanted to crush the Reformation was not an option for Luther. ${ }^{33}$ Instead, he called for repentance in face of laxity in faith. He produced the Large Catechism and the Small Catechism (1529), the Personal Prayer Book (1522), and the Wittenberg Hymnbook (1529) in order to strengthen the personal faith of Christians. But he also actively participated in the publication of the Qur'an so that Christians could know firsthand what the other faith taught, in order that they might confidently and cheerfully hold on to the Christian gospel.

\footnotetext{
${ }^{29}$ Ibid., 25.

${ }^{30}$ Ibid., 26.

31 "Evangelikale kritisieren Islam-Initiative von Bischof Bedford Strohm," evangelisch.de, https://www.evangelisch.de/inhalte/123728/04-08-2015/

evangelikale-kritisieren-islam-initiative-von-bischof-bedford-strohm.

${ }^{32}$ Reformation und Islam, 28.

${ }^{33}$ Cf. Hans Schwarz, True Faith in the True God:An Introduction to Luther's Life and Thought, rev. and exp. ed. (Minneapolis: Fortress, 2015), 43.
} 


\title{
Luther and the Reform of Marriage and Family Life
}

\section{YOUNGCHUN CHO}

\begin{abstract}
Martin Luther was a reformer not only of Christian doctrines and church practices, but also of marriage and family life. This article investigates how Luther transformed the medieval concept of marriage and reconstructed family life as a sacred sphere in which the believer can exercise faith and Christian duties coram Deo, examining Luther's criticism of celibacy, his view of sexuality and women, and his pastoral insights on the responsibilities of husbands in relation to wives and parents in relation to children, thereby demonstrating that Luther's influence permeated the broader sphere of human life in the early sixteenth century.
\end{abstract}

\section{Introduction}

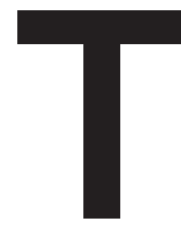

he twenty-first century is often perceived as obsessed with sex, but sixteenth-century Europe was no less afflicted than our modern world. Marriage and sex were tainted by immorality and number of other disorders, and the Reformers sought to provide helpful guidelines and thereby reform conjugal relations of their age. Martin Bucer discussed the subject of marriage and sex in detail and in depth, ${ }^{1}$ and it is reported that Calvin spent more than sixty percent

1 Herman J. Selderhuis, Marriage and Divorce in the Thought of Martin Bucer, trans. John Vriend and Lyle D. Bierma (Kirksville, MO: Thomas Jefferson University Press, 1999). 
of his time in pastoral care on issues of marriage, sex, and family. ${ }^{2}$ The Reformation was not limited to the mere reform of doctrines or liturgical systems; it also had enormous impact on marriage and the home. Martin Luther was a central figure in the reform of marriage.

We will investigate how Luther as a pastor laid a foundation for Christian marriage and family, beginning with his criticism of celibacy in his early writings, continuing with his view of sexuality and women, and ending with his pastoral teachings on the responsibilities of husbands in relation to wives and parents in relation to children.

\section{Martin Luther on Marriage}

\section{Elevation of Marriage over Celibacy}

The medieval understanding of marriage was ambivalent. On the one hand, the medieval church seemed to have a high view of marriage as a natural institution created by God and as a sacrament of faith through which God's grace is communicated. Since marriage was understood as a sacrament, ecclesiastical authority controlled every aspect of married life. On the other hand, the prevailing view of sexuality in medieval Christendom was that celibacy is spiritually superior to marriage. This originated from the church fathers' negative attitude toward concupiscence. Viewing human sexual desires as the product of the fall and thus sinful, Origen is said to have castrated himself in order to literally follow Matthew 19:12, and Tertullian declared that sexual cravings or delights have no place in the Christian life. ${ }^{3}$ Jerome also made an interesting comparison between virginity and marriage, giving "virginity a numerical value of one hundred, widowhood, sixty, and marriage, thirty." 4 The Council of Elvira officially prohibited clerical marriage in the early fourth century, and the medieval church continued to affirm a strict code of sexual ethics as a distinguishing mark of the supremacy of Christian ethics over paganism. ${ }^{5}$ Theologians and canonists "subordinated the duty of propagation to that of celibate contemplation, the natural drive for sexual union to the spiritual drive for communion with God." ${ }^{\text {Although }}$

\footnotetext{
2 John Witte and Robert M. Kingdon, Sex, Marriage, and Family in fohn Calvin's Geneva (Grand Rapids: Eerdmans, 2005); André Biéler, L’homme et la femme dans la morale calviniste (Geneva: Labor \& Fides, 1963).

3 James Brundage, Law, Sex, and Christian Society in Medieval Europe (Chicago: University of Chicago Press, 1990), 64.

4 Steven E. Ozment, Protestants:The Birth of a Revolution (New York: Doubleday, 1992), 153.

5 Brundage, Law, Sex, and Christian Society in Medieval Europe, 69-70.

6 John Witte, "The Reformation of Marriage Law in Martin Luther's Germany: Its Significance Then and Now," Fournal of Law and Religion 4.2 (1986): 300.
} 
marriage remained a sacrament and a duty after the fall, the celibate clergyman turning away from any sexual desires was praised as the ideal man or first-rate Christian.

Such a two-tiered view of marriage not only "oppressed the laity," but also "tormented the clergy." Many monks and nuns suffered from strong desires and the pangs of conscience because they violated the monastic codes. Far from being liberated from sexual desires through the celibate life, the clergy was enslaved to desire and committed to immorality. One anonymous clergyman, who lived with concubines and fathered seventeen children, bemoaned his dilemma:

Thus am I entangled: on the one hand, I cannot live without a wife; on the other, I am not permitted a wife. Hence, I am forced to live a publicly disgraceful life, to the shame of my soul and honor and to the damnation of many who have taken offense at me. ... How shall I preach about chasteness and against promiscuity, adultery, and knavish behavior, when my own whore goes to church and about the streets and my own bastards sit before my eyes?

The bad effects of the celibate life, such as prevailing concubinage and illegitimate children, made the Reformers rise up against the medieval church law and practice. Luther criticized the papacy for insisting on clerical celibacy, claiming that it did so in order to keep an important source of its revenue, the so-called "whore tax." $\mathrm{He}$ also spoke of the disastrous phenomenon of thousands of aborted children being buried around convents. ${ }^{10}$

Luther's attack against compulsory celibacy was not explicit until 1520. In 1519 he preached "A Sermon on the Estate of Marriage," in which his view of marriage was still in line with the medieval understanding in two respects. First, Luther held to the medieval view of marriage as a "remedy against sin": "[After the fall] the married state is now no longer pure and free from $\sin$. The temptation of the flesh has become so strong and consuming that marriage may be likened to a hospital for incurables which prevents inmates from falling into graver sin." Ephesians 5:32, he acknowledged that the estate of marriage is "a wonderful

7 Carter Lindberg, "The Future of a Tradition: Luther and the Family," All Theology Is Christology, ed. Dean Wenthe (St. Louis: Concordia Theological Seminary, 2000), 135.

8 Ozment, Protestants, 79.

9 Martin Luther, "Against the Spiritual Estate of the Pope and the Bishops Falsely So Called," in Luther's Works (hereafter $L W$ ), ed. Jaroslav Pelikan and Helmut T. Lehman (St. Louis: Concordia, 1955-86), 39:290-91.

${ }^{10}$ Susan C. Karant-Nunn and Merry E. Wiesner-Hanks, eds. and trans., Luther on Women: A Sourcebook (Cambridge: Cambridge University Press, 2003), 169.

${ }^{11}$ Martin Luther, "A Sermon on the Estate of Marriage," LW 44:9. Italics added. 
sacrament" that signifies a great reality of "the union of the divine and human natures in Christ." 12

The following year, however, Luther distanced himself from the Roman Catholic view of marriage. In The Babylonian Captivity of the Church, he maintained that marriage is not a sacrament and translated the Greek word mysterion in Ephesians 5:32 as "mystery" rather than as "sacrament." $13 \mathrm{He}$ also objected to the Roman attempts to regulate married life by the enactment of "impediments," and he denounced the Summa Angelica, the official document that lists eighteen impediments to marriage, as "worse than Diabolical."14 Instead, he reduced the number of those impediments to one: sexual impotence. ${ }^{15}$ Thus Luther sought to stop the excessive control over marriage life exercised by the church. In this regard, it is noteworthy that he connected his view of marriage to his two-kingdoms theory. Rejecting the sacramental concept of marriage, Luther saw marriage as an institution of the earthly kingdom and urged the secular authority to take up marriagerelated cases. According to John Witte, Luther's shift of "jurisdiction over marriage from the church to the state" was an important change for later development of German secular marriage law. ${ }^{16}$

Luther's more systematic and theological protests against the medieval argument for the superiority of celibacy are found in his Address to the Christian Nobility of the German Nation (1520). In this work, Luther sought to remove the false walls that the papacy had built in order to separate the spiritual area from the secular and to elevate the church over the state. Luther declared that there is no difference between "religious" work and "secular" work, for "all Christians whatsoever really and truly belong to the religious class, and there is no difference among them except in so far as they do different work." 17 In this regard, Luther criticized people who pursued religious pilgrimages at the expense of the more important command from God that "a man should cherish his wife and children, and perform the duties proper to the married state."

He applied his theology of vocation to sexuality in particular, denying that celibacy is more spiritual than and superior to marriage. While acknowledging that voluntary chastity is a respectable virtue and helps some to devote

\footnotetext{
12 Ibid., 10.

${ }^{13}$ Martin Luther, "The Babylonian Captivity of the Church," in Martin Luther: Selections from His Writings, ed. John Dillenberger (New York: Doubleday, 1961), 326-27.

${ }^{14}$ Ibid., 330.

${ }^{15}$ Ibid., 330-37.

${ }^{16}$ Witte, "The Reformation of Marriage Law in Martin Luther's Germany," 296.

${ }^{17}$ Martin Luther, "To the Christian Nobility," in Martin Luther: Selections from His Writings, 407.
} 
themselves more fully to study the Word of God and theology, Luther clearly asserts that celibacy per se is not spiritual. ${ }^{18}$ For him, celibacy is such a special miracle of God that very few people are called to it, and the majority ought to be permitted to marry. Therefore, priests with troubled consciences due to their secret wives and children are free to enter into marriage and have conjugal union. Even if people blame them for such marriages, "they are certainly espoused in God's sight." 19 What is more, in order to better understand family-related problems and give practical counsel to their parishioners, pastors need to live among the people and keep house as other people do. ${ }^{20}$ And no one who is married is less spiritual than monks and nuns, because faith equalizes "the value of all work before God."21 Thus, Luther tore down the strong wall not by eliminating the priesthood, but by eliminating the laity and granting spiritual estate to every work exercised out of faith. As Carter Lindberg puts it, "Luther's application of evangelical theology to marriage and family desacramentalized marriage, desacralized the clergy and resacralized the life of the laity."22

\section{Centrality of Sex in Married Life}

Along with elevating marriage to a spiritual estate, another of Luther's contributions was to correct the longstanding medieval conception that human sex is impure. On the one hand, since marriage is one of God's creation ordinances and it includes marital sex, the sexual union of a man and woman is holy and pleasing to God. It is neither different from nor inferior to any other ordinary work like eating, drinking, sleeping, or waking. Whoever tries to resist it necessarily falls into fornication and secret sins because "this is a matter of nature and not of choice." ${ }^{23}$ On the other hand, marriage and sex is holy on the ground that God redeems it by his grace. Though it was part of a creation ordinance, Adam's fall distorted the original purity of sex as well as that of all other aspects of human life. Thus the estate of marriage became impure in that it was not free from the effects of original sin. Yet God delivers even this marital estate from its sinfulness, not "by taking away desire or love for one's bride, or by forbidding marital

\footnotetext{
${ }^{18}$ In his later treatise on "The Estate of Marriage" (1524), Luther says, "It is God's word and the preaching which make celibacy ... better than the estate of marriage. In itself, however, the celibate life is far inferior." $L W 45: 47$.

${ }^{19}$ Luther, "To the Christian Nobility," 450.

${ }^{20}$ Ibid., 449.

${ }^{21}$ Karlfried Froehlich, "Luther on Vocation," in Harvesting Martin Luther's Reflections on Theology, Ethics, and the Church, ed. Timothy Wengert (Grand Rapids: Eerdmans, 2004), 123.

${ }^{22}$ Lindberg, "Luther and the Family," 133.

${ }^{23}$ Luther, "The Estate of Marriage," 18.
} 
intercourse," but by redeeming or renewing its nature through his grace. ${ }^{24}$ Thus, based upon God's works of creation and redemption, Luther affirms that sexual activity within wedlock is holy and pure.

Luther also objected to the medieval notion that marital sex is allowed only for procreation and is, in this respect, a necessary evil. According to him, it is not only for having children, but also increasing intimacy and affection between spouses. The centrality of sex to marriage is already seen in his discussion on the impediments to marriage: sexual impotence is the only case inhibiting one from getting married. Luther also accused preachers who assigned particular times for sleeping with spouses and excluded many days of being "filth-preachers," and he admonished people not to "pay any attention to holy days or work days, or other physical considerations [i.e., the wife's pregnancy]." 25

Luther's stress on sexuality is demonstrated most clearly in his view of divorce. Luther allowed three grounds for divorce: sexual impotence, adultery, and refusal of conjugal duty. If a woman has unwittingly married an impotent man, she should ask him to tolerate her secret relations with another man. If he does not permit this, the woman can separate herself from him. Luther argues that such a woman is still in a state of salvation despite the divorce, "because in this case a mistake due to ignorance of the man's impotence created a false situation which impedes the marriage proper." ${ }^{26}$ Likewise, if a husband wants conjugal union but a wife refuses it, he can warn her by saying, "If you will not, another will; the maid will come if the wife will not." If the wife continues to refuse, Luther advises the husband to "get rid of her" and "take an Esther and let Vashti go." ${ }^{27}$ His advocacy of the secret bigamy due to an impotent husband or his approval of abandoning a wife on account of refusing the conjugal duty might sound radical and embarrassing to the ears of modern readers, but it clearly illustrates how central the physical union of spouses was to Luther's view of the marriage relationship.

Luther's view of sexuality was so positive that it is no wonder that the Roman polemicists accused him of being the "most insane and libidinous of apostates." 28 It was rumored that Luther helped nuns to run away from convents in order to satisfy his own carnal appetites, and that he had three

${ }^{24}$ Karant-Nunn and Wiesner-Hanks, Luther on Women, 152-53.

${ }^{25}$ Luther, "The Estate of Marriage," 35-36.

${ }^{26}$ Luther, "The Babylonian Captivity of the Church," 337.

${ }^{27}$ Luther, "The Estate of Marriage," 33-34.

${ }^{28}$ Jeanette C. Smith, "Katarina von Bora through Five Centuries: A Historiography," Sixteenth Century fournal 30 (1999): 754. 
wives at the same time.${ }^{29}$ Luther's marriage to Katharine was condemned not simply as adultery but even as incest by the Catholic Church on the ground that a monk and a nun are like spiritual brother and sister. Thomas More, a vigorous opponent of the Reformation, spoke ill of Luther's marriage: "Luther not only teaches monks, friars, and nuns to marry, but also being a friar has married a nun himself and with her lies under the name of wedlock in open incestuous lechery without care or shame. ${ }^{30}$ Luther himself was concerned about a rumor that a monster baby would be born from the ex-monk and ex-nun couple, but was relieved when Katharine gave birth to a healthy and normal baby. ${ }^{31}$

In regard to the centrality of sexuality to conjugal relations, another significant fact that draws our attention is that Luther and other Reformers began endorsing divorce under some circumstances. Since marriage was considered as a sacrament in the medieval church, divorce was strictly prohibited on the basis of Matthew 19:6, "What God has joined together, let no one separate." Even when a spouse committed adultery, the church commanded "only the separation of a couple from a common bed and table, not the dissolution of the marriage bond and the right to marry again." ${ }^{32} \mathrm{By}$ contrast, the Protestants genuinely allowed divorce and remarriage. Of course, early Reformers were well aware of the possible abuse of this allowance and warned against a rash attempt to achieve divorce. Luther demanded careful investigation and decision of a public divorce by the state, the church, or the two in cooperation. ${ }^{33}$ In Zurich, a petition of divorce involved an extended process in which a woman had to demonstrate her husband's impotence through medical investigation, and, even after his impotence was proved, the marriage court required a probationary period of one to five years. ${ }^{34}$ Calvin's Geneva also allowed only about thirty divorces during a twenty-three-year period, which implies that divorce and remarriage were not easily attained. ${ }^{35}$ Nevertheless, it was a significant change that divorce became available, at least theoretically, for the first time in Western Christendom, thereby opening the way for later development.

${ }^{29}$ Thomas A. Fudge, "Incest and Lust in Luther's Marriage: Theology and Morality in Reformation Polemics," Sixteenth Century fournal 34 (2003): 334.

${ }^{30}$ Ibid., 341.

${ }^{31}$ Ibid., 337.

32 Ozment, Protestants, 163.

${ }^{33}$ Luther, "The Estate of Marriage," 32.

${ }^{34}$ Steven Ozment, When Fathers Ruled: Family Life in Reformation Europe (Cambridge: Harvard University Press, 1983), 94.

${ }^{35}$ Scott Hendrix, "Luther on Marriage," in Harvesting Martin Luther's Reflections on Theology, Ethics, and the Church, ed. Timothy J. Wengert (Grand Rapids: Eerdmans, 2004), 176. 


\section{Dignity of Women}

With respect to marriage, another distinction between the medieval church and Luther concerns the view of women. On the grounds that Eve was tempted first by the serpent, women had been regarded as a source of evil and inferior to men from the early church through the medieval period. An example of this mindset was Tertullian, who defined woman as "a temple built over a sewer"; Augustine warned men against touching women, and Aquinas viewed women as "defective and misbegotten." ${ }^{36}$ Luther grew up in the male-dominated structure of village, school, and cloister. Some of his statements, such as "women have narrow shoulders and wide hips ... therefore they ought to be domestic," sound like male chauvinism. ${ }^{37}$ However, this is not the whole picture of Luther's view of women, as he also strongly defended the dignity of women through his writings and his ministry.

To begin with, Luther's advocacy of women's rights is found in one of his proposals to the Christian nobility in 1520: "Would to God also that each town had a girls' school where, day by day, the girls might have a lesson on the gospel." ${ }^{38} \mathrm{He}$ continued to speak of the necessity of such an institution for women's education, and, as a result, a girl's school was founded in the city of Zwickau in 1526, and the Wittenberg Mädchenschule was founded in 1533. Luther's primary aim was to teach them the Bible and thereby train them to be godly wives and mothers in the household, and so provide them with intellectual content. For this reason, Susan Karant-Nunn argues that the educational quality or curriculum of the girls' school was substantially different from and inferior to that of the boys' grammar school, and that the only teachings inculcated were merely moral matters of modesty, decency, and chastity. ${ }^{39}$ Acknowledging such limitations, Jonathan Zophy argues that the institution of the Lutheran girls' schools was nevertheless "an advance over the almost total absence of similar schools for girls in Catholic Germany." 40

${ }^{36}$ Citation comes from Jonathan W. Zophy, "WWe Must Have the Dear Ladies': Martin Luther and Women," in Pietas et Societas: New Trends in Reformation Social History, ed. Kyle C. Sessions and Phillip N. Bebb (Kirksville, MO: Truman State University Press, 1985), 144.

${ }^{37}$ Ozment, Protestants, 152.

${ }^{38}$ Luther, "To the Christian Nobility," 475.

${ }^{39}$ Susan Karant-Nunn, "Continuity and Change: Some Effects of the Reformation on the Women of Zwickau," Sixteenth Century fournal 13.2 (1982): 19. Referred to in Zophy, "We Must Have the Dear Ladies," 148. In another article, Karant-Nunn also maintains that the establishment of the girls' school in Zwickau "was designed to reinforce women's roles within the home." "Transmission of Luther's Teaching on Women and Matrimony: The Case of Zwickau," Archiv für Reformationsgeschichte 77 (1986): 40.

${ }^{40}$ Zophy, "'We Must Have the Dear Ladies," 148. 
Furthermore, Luther's high view of woman is demonstrated well in his discussion on marriage. Based on Genesis 1:27 and 1:31, which state that both man and woman are created by God, Luther writes, "the man is not to despise or scoff at the woman or her body, nor the woman the man. But each should honor the other's image and body as a divine and good creation." ${ }^{\prime 4}$ He goes on to stress that God created woman as a good helper (Gen 2:18). Luther repeats this several times because he is deeply concerned about the poisonous teachings of many pagan books "which treat of nothing but the depravity of womankind and the unhappiness of the estate of marriage." ${ }^{42}$ He warns the young to be on their guard and keep themselves from inhaling poison when they read such books. Since marriage is God's good will and work, the devil seeks to spread prejudices against woman in order to "frighten men away from this godly life." 43 Therefore, every young man should beware of such an evil deception and keep in mind the partnership of woman and man in the marriage relationship.

Luther's stress on the equality between man and woman is also found in his Large Catechism (1529). In his exposition of the fourth commandment, he does not distinguish the role of the father from that of the mother, but places the same authority and power upon both. Parental responsibilities are equally incumbent upon both mother and father. Luther's explanation of the sixth commandment also shows his advocacy of equality. While using several texts that are usually used to emphasize the wife's duty to submit to her husband, Luther does not mention any inequality, but urges mutual duty and responsibility to keep the marriage secure. "This outspoken equality was no small feat for a thinker whose entire social life was marked by inequalities." 44

Furthermore, Luther even describes the woman as a heroic figure. According to Mickey L. Mattox's interesting article, Luther's portrayal of Eve changed after his marriage in 1525. In 1523 and 1524 Luther interpreted Eve's confrontation with the devil as a "talkative and superstitious" act, and argued that she should have avoided the talk with the devil and instead referred the devil's question to Adam, her superior. However, in his lectures on Genesis between 1535 and 1545, he pictures Eve's conversation with the serpent as a heroic act that resulted from the recognition of her responsibility to rule over the creatures, of which the serpent was one. In other words,

\footnotetext{
${ }^{41}$ Luther, "The Estate of Marriage," 17-18.

${ }^{42}$ Ibid., 36.

${ }^{43}$ Ibid., 37.

44 Timothy J. Wengert, "Martin Luther and the Ten Commandments in the Large Catechism," in The Pastoral Luther, ed. Timothy J. Wengert (Grand Rapids: Eerdmans, 2009), 143.
} 
Eve proved herself to be a coworker with Adam as ruler and keeper by confronting the serpent. ${ }^{45} \mathrm{He}$ also portrayed Sarah's request that Abraham expel Hagar and Ishmael from his household as an active and heroic confession of faith. ${ }^{46}$ Thus Luther praised female figures in the Genesis narrative as great saints living by faith.

In addition to elevating woman's status to partner or coworker, Luther sought to protect women's rights in several ways. First of all, his approval of divorce on the basis of adultery and impotence would help women to assert their freedom from an unjust marriage. When a woman wants a divorce but obtains neither her husband's consent nor the investigation of the secular authority, Luther writes, "I would counsel her to contract matrimony with someone else, and flee to some distant and unknown region." ${ }^{.77}$ An interesting anecdote about a case that took place around 1524 also illustrates his advocacy of women's rights. Luther heard that a violent husband had been beating his wife for many years. After careful investigation, he concluded that the husband was insane and the wife ought to separate from him, and so he requested the Wittenberg city council to permit the divorce. The magistrates did not agree with Luther and rejected his petition-which implies that Luther was no dictator of Wittenberg-but Luther did not surrender to the decision of the city council; instead, he continued to appeal to the elector for the woman's security until he finally received the elector's approval for her separation. ${ }^{48}$ This is evidence that Luther not only insisted on women's rights in speech or writing, but he also fought for them in his ministry.

A letter written in 1524 shows another category of women whom Luther attempted to protect. In the letter entitled "Parents Should Neither Compel nor Hinder the Marriage of Their Children," he does not follow uncritically the stipulation of Exodus 22:16-17 "If a man lies with a maiden, he shall endow her and make her his wife; but if her father refuses this, he shall provide for her the dowry"). Luther's interpretation is that the father should not refuse to give her to the man at all in this case, but ought to allow the marriage; otherwise, the woman could be in jeopardy:

${ }^{45}$ Mickey L. Mattox, "Luther on Eve, Women, and the Church," in The Pastoral Luther, 256-59.

${ }^{46}$ Ibid., 264.

${ }^{47}$ Luther, "The Babylonian Captivity of the Church," 337.

48 Timothy J. Wengert, "Martin Luther on Spousal Abuse," Lutheran Quarterly 21 (2007): 337-39. 
At that time [i.e., in Moses's time], however, there was not so much stress laid on virginity. In our day there is a strong aversion to marrying a despoiled woman; such a marriage is regarded as disgraceful. As a result the second part of this law of Moses, with respect to parental authority over the despoiled virgin, is harmful and a source of peril to the child. ${ }^{49}$

Luther's exposition of Exodus 22:16-17 demonstrates 1) his humanist concern to take into consideration the difference between Moses's day and his own day - which is also seen in his application of the ninth and tenth commandments ${ }^{50}$ - and 2) his pastoral concern for the possible peril of a despoiled virgin. Although he held a high view of parental authority and demanded children's faithful obedience, Luther saw protection of the despoiled woman as more important than the authority of the parents.

How much influence did Luther's view of women have on male-dominated European culture? Was Luther, or the Reformation in general, good for women in the sixteenth century? Several scholars have argued that Luther's positive evaluation of marriage did women more harm than good. According to them, women had enjoyed more independence and freedom in the convent or even in the public brothel than in the home. Merry Wiesner, drawing on recent research, notes that "women fought harder than men to retain their religious houses" and to prevent the closing of convents and monasteries, ${ }^{51}$ and Karant-Nunn claims that monasticism provided women with a refuge through which they could escape from male dominance in the household and the high risks accompanying pregnancy and childbirth. ${ }^{52}$ Though women's opportunity for education was expanded, that education was merely used to reinforce the male-dominated family and society. A daughter's prayer was, "Let me become a good housekeeper," and a housewife's prayer was, "[May] I humble myself before my husband and raise my child to fear you and to live in decency." ${ }^{53}$ Family became another kind of

\footnotetext{
${ }^{49}$ Martin Luther, "Parents Should Neither Compel nor Hinder the Marriage of Their Children," $L W$ 45:391.

${ }^{50}$ Pointing out that Luther did not apply the tenth commandment directly to his own day, Wengert states, "What a remarkable turn of a text! Here Luther, who more than anyone focuses theology on the Word alone, dismisses a clear Word of God as inapplicable for social reasons! We have no slaves, and women are not property!"Wengert, "Martin Luther and the Ten Commandments in the Large Catechism," 135.

${ }^{51}$ Merry E. Wiesner, "Studies of Women, the Family, and Gender," in Reformation Europe: A Guide to Research, vol. 2 (St. Louis: Center for Reformation Research, 1992), 164.

${ }^{52}$ Karant-Nunn, "Transmission of Luther's Teaching on Women and Matrimony," 31.

${ }^{53}$ Cited in Susan Karant-Nunn, "Kinder, Küche, Kirche: Social Ideology in the Sermons of Johannes Mathesius," in Germania Illustrata, ed. Andrew C. Fix and Susan C. Karant-Nunn (Kirksville, MO: Sixteenth Century Journal Publishers, 1992), 130-31.
} 
nunnery that inhibited women's self-realization and subjected wives to their husbands' authority.

Nevertheless, it would be anachronistic to strictly apply the standard of modern feminism to the sixteenth century and thereby depreciate the Reformers' endeavor to reform marriage and family life. Despite many limitations, it is certain that they rebelled, or at least started rebelling, against the long-held social structure of inequality between man and woman. This is especially true of Luther, who said, "I wouldn't give up my Katie for France or for Venice," and designated his wife "heir to everything" in his last will and testament against the traditional German practice; ${ }^{54}$ he should thus be appreciated as a forerunner of the modern advancement of women's rights.

\section{Martin Luther on Family Life}

Marriage is not merely for satisfying suppressed sexual appetites and elevating women's dignity. It exists primarily for glorifying and pleasing God. In this respect, marriage and family can serve as a great school for sanctification and Christian character. Home is the place where what Luther declared as the essence of Christian ethics can be exercised: "A Christian man is the most free lord of all, and subject to none; a Christian man is the most dutiful servant of all, and subject to everyone." Though some accuse Luther's doctrine of the priesthood of all believers of promoting individualism, he actually had great concern for the communal aspect of faith: "To be human is to be open for others, to live with one another and mutually to bear burdens." ${ }^{55}$ Whereas monks and nuns sought to pursue holiness in isolation from earthly cares and struggles, Luther urged the Christian to practice sanctification in the midst of difficulties and relational conflicts. This shows Luther's pastoral genius quite clearly.

In order to enjoy a delightful marriage, first of all, one ought to recognize about the estate of marriage that "God himself instituted it, brought husband and wife together, and ordained that they should beget children and care for them." ${ }^{56}$ To put it simply, to know the lordship of God over married life is the beginning of godly marriage. While the pagans scoff at laborious housework and say that "it is better to remain free and lead a peaceful, carefree life," the Christian man looks at all the annoying and despised duties differently in light of the Spirit and praises God with a humble heart:

\footnotetext{
54 Ozment, Protestants, 160.

${ }^{55}$ Lindberg, "Luther and the Family," 140.

${ }^{56}$ Luther, "The Estate of Marriage," 38.
} 
O God, ... I also know for a certainty that it meets with thy perfect pleasure. I confess to thee that I am not worthy to rock the little babe or wash its diapers, or to be entrusted with the care of the child and its mother. How is it that I, without any merit, have come to this distinction of being certain that I am serving thy creature and thy most precious will ${ }^{57}$

Likewise, all that a wife does at home are "truly golden and noble works," and even childbirth is a glorious suffering in subservience to God. Luther summarizes his whole point in a witty remark: "When a father goes ahead and washes diapers or performs some other mean task for his child ... God, with all his angels and creatures, is smiling." 58

\section{Responsibilities of Husband and Wife}

In the Large Catechism, Luther teaches that God values the conjugal relationship and wants to protect its purity by giving the sixth commandment: "You should carefully note, first, how highly God honors and praises this walk of life, endorsing and protecting it by his commandment." ${ }^{59}$ The duty of husband and wife is not merely to keep marriage from adultery, but "to love and cherish the spouse whom God has given them." ${ }^{60}$ Married love is over and above all other kinds of love in that it desires nothing but the loved one. Husband and wife should say, "It is you I want, not what is yours: I want neither your silver nor your gold; I want neither. I want only you. I want you in your entirety, or not at all." ${ }^{\prime 1}$

Everything runs smoothly in the early stage of marriage, says Luther. A husband and wife who have just married love each other with all their hearts. Once their initial curiosity is satisfied, however, the devil begins to arouse boredom with their married life, thereby making them look for another man or woman. Those who do not walk by the Word of God become easily tired of their spouses and soon want change or divorce. ${ }^{62}$ But Christian couples should be different and be consistent in their married love. The Word of God, not human desire or appetite, should lead and guard the Christian marriage. A man armed with God's Word will not be attracted by another woman, but will say,

\footnotetext{
${ }^{57}$ Ibid., 39.

${ }^{58}$ Ibid., 40.

${ }^{59}$ Martin Luther, "The Large Catechism," in The Book of Concord, ed. Robert Kolb and Timothy J. Wengert (Minneapolis: Augsburg Fortress, 2000), 414.

${ }^{60}$ Ibid., 415.

${ }^{61}$ Luther, "A Sermon on the Estate of Marriage," 9.

${ }^{62}$ Martin Luther, "The Sermon on the Mount," LW 21:89, 95.
} 
Is she beautiful? As far as I am concerned, she is not very beautiful. And even if she were the most beautiful woman on earth, in my wife at home I have a lovelier adornment, one that God has given me and has adorned with His Word beyond the others, even though she may not have a beautiful body or may have other failings. ... I know that $\mathrm{He}$ and all the angels are heartily pleased if I cling to her lovingly and faithfully. Then why should I despise this precious gift of God and take up with someone else, where I can find no such treasure or adornment? ${ }^{33}$

Luther was also well aware that married life is not free from troubles and hardships. Some occasions in which husbands and wives have difficulty keeping a good relationship can take place. But it is in this situation that marriage especially serves as a school for faith. For example, a woman could live with a rude and unbearable husband. Should she depart from such an evil husband? Luther's counsel to her is to be equipped with Christian fortitude and endure his ill behavior because "that would doubtless be a wonderfully blessed cross and a right way to heaven." ${ }^{\prime 4}$ Similarly, when a wife becomes ill and accordingly unable to fulfill the conjugal duty, her husband should remain in the relationship rather than take another wife. According to Luther, this is a great opportunity to put one's trust in God's providence and await his good pleasure:

Consider that in this invalid God has provided your household with a healing balm by which you are to gain heaven. Blessed and twice blessed are you when you recognize such a gift of grace and therefore serve your invalid wife for God's sake. ... If you will earnestly serve your invalid wife, recognize that God has placed this burden upon you, and give thanks to him, then you may leave matters in his care. $\mathrm{He}$ will surely grant you grace, that you will not have to bear more than you are able. ${ }^{65}$

\section{Responsibilities of Parents}

Luther also stresses the responsibilities of parents. The greatest good in marriage is that "God grants offspring and commands that they be brought up to worship and serve him." Also, "there is no greater or nobler authority on earth than that of parents over their children, for this authority is both spiritual and temporal." ${ }^{66}$ First, as the temporal authority, parents should provide material support for their children. They should not spare money or effort for their education. If one is concerned about the lack of financial resources to support children, "he should take satisfaction in this; first, that his status and occupation are pleasing to God; second, that God will most

\footnotetext{
${ }^{63}$ Ibid., 87.

${ }^{64}$ Luther, "The Estate of Marriage," 34.

${ }^{65}$ Ibid., 35.

${ }^{66}$ Ibid., 46.
} 
certainly provide for him if only he does his job to the best of his ability."67 What is more, parents ought to help their children find suitable spouses, thereby establishing new households. Luther warned parents neither to prevent their children from getting married nor to put their marriage off for any reason. If parents fail to perform this duty, he advises children to marry without the consent of their parents. ${ }^{68}$

Though it is important for parents to perform their responsibilities as temporal authorities, providing material support is only a small part of parental duty. Much more important is their spiritual role. In this regard, Luther calls parents "apostles, bishops, and priests to their children,"69 and he also calls children "the churches, the altar, the testament, the vigils and masses." 70 To bring up children with Christian minds to worship and serve the Lord is the "shortest road to heaven."71 Luther warns his reader that many parents pay more attention to the care of their children's bodies than to that of their souls, and merely want their children to get ahead or become rich in this world. But this should be always remembered:

We must not think only of amassing money and property for them. God can provide for them and make them rich without our help, as indeed he does daily. But he has given us children and entrusted them to us precisely so that we may raise and govern them according to his will; otherwise, God would have no need of fathers and mothers. Therefore let all people know that it is their chief duty - at the risk of losing divine grace - first to bring up their children in the fear and knowledge of God. ... ${ }^{72}$

When parents stand before God at their death and on the day of judgment, they will not be asked about how much money or property they piled up for their children, but about how sincerely they taught the Word of God and the Christian faith to the children whom God entrusted to them. ${ }^{73}$

\section{Responsibilities of Children}

Luther's teachings on the duty of children are well summarized in his exposition of the fourth commandment, "You are to honor your father and mother." According to Wengert's analysis of Luther's Large Catechism, the

\footnotetext{
67 Ibid., 47-48.

${ }^{68}$ Luther, "Parents Should Neither Compel nor Hinder the Marriage of Their Children," 387-90.

${ }^{69}$ Luther, "The Estate of Marriage," 46.

70 Luther, "A Sermon on the Estate of Marriage," 14.

71 Ibid., 12.

72 Luther, "The Large Catechism," 410.

${ }^{73}$ Luther, "A Sermon on the Estate of Marriage," 13.
} 
Ten Commandments "are given in descending order of importance." ${ }^{14}$ The earlier commandments have authority over the later ones. The first three commandments in relation to God dominate applications of the following commandments in relation to man. Accordingly, if a child's parents would force him to abandon faith in God, prayer, or worship, he should not obey his parents. Yet, in all other cases that do not contradict Christian faith, one ought to follow the words of parents above those of any other human. Obedience to the authority of parents is the best virtue of children.

This is because parents are the reminder of God's benevolence and providence. As God's representatives on earth, parents are worthy of reverence in all circumstances. Just as people easily forget "how God feeds, guards, and protects us and how many blessings of body and soul he gives us," so children forget the benevolent works of their parents. ${ }^{75}$ Luther criticizes the papacy for fostering such disregard for parents. By encouraging monastic life and elevating obedience to the church over obedience to parents, the Catholic Church neither taught nor heeded the fourth commandment. Luther once accepted this Catholic teaching, but he expressed his regret about entrance to the monastery when he wrote On Monastic Vows (1521). He dedicated this treatise to his father, Hans Luther, and asked his father's forgiveness for the decision to be a monk and the willful violation of the fourth commandment. ${ }^{76}$

What if parents are poor or not worthy of respect, humanly speaking? Should children still obey them? Luther's answer is yes. Obedience to parents does not depend upon whether they are good or bad, but upon God's will.

However lowly, poor, feeble, and eccentric they may be, they are still their mother and father, given by God. They are not to be deprived of their honor because of their ways or failings. Therefore, we are not to think of their persons, whatever they may be, but of the will of God.... ${ }^{77}$

Luther continues to affirm that it is "for God's sake" that "the young people should banish all other things from their sight and give first place to this commandment." 78 Even when parents force unwilling marriage-though Luther strongly warns parents against this-Christian children have to remain with their spouses, remembering the example of Jacob, who endured Laban's injustice "although in the eyes of mankind he was under no

\footnotetext{
${ }^{74}$ Wengert, "Martin Luther and the Ten Commandments in the Large Catechism," 139.

${ }^{75}$ Luther, "The Large Catechism," 404.

${ }^{76}$ Froehlich, "Luther on Vocation," 126.

${ }^{77}$ Luther, "The Large Catechism," 401. Italics added.

${ }^{78}$ Ibid., 402.
} 
obligation." ${ }^{79}$ In other words, poor or evil parents can be the instruments by which the children practice their trust in God's sovereignty.

All in all, marriage and family make for a wonderful school where Christians can test and practice their faith in God and pursue sanctification. Luther emphasized the function of the Christian family as a great sanctifier by using such strong language as "a blessed cross and a right way to heaven," and "the shortest road to heaven." Luther even encouraged the potential husband who is worried about material well-being by saying, "God will most certainly provide for him if only he does his job to the best of his ability," which is an echo of the medieval scholastic idea of "facere quod in se est" (do what is in you). ${ }^{80}$

However, it should be observed that Luther did not introduce any notion of meritorious works for salvation. His basic presupposition is that marriage and family are a gift from God rather than a human achievement. As Luther stressed his view of a passive righteousness before God rather than an active righteousness in his soteriology and claimed that "salvation is the source of life rather than the goal of life," ${ }^{81}$ he said the same here: what makes marriage and family holy is faith in and gratitude for God's benevolent gift, not human work.

\section{Conclusion}

In his biography of Luther, Roland Bainton concludes that "the influence of the man on his people was deepest in the home. In fact, the home was the only sphere of life which the Reformation profoundly affected." ${ }^{82}$ Some would see Bainton's comment as an exaggeration and point out the practical limitations of Luther's reform of marriage. Nevertheless, his contributions to the establishment of modern Christian marriage and family life should be acknowledged. Marriage and family had been in his mind all the time. Luther's early sermons and treatises were full of attacks against the superiority of celibacy held by the papacy. Throughout his writings and ministry, he elevated and protected the rights of women and highlighted the importance of the Christian home. He put his teachings into practice by marrying Katharine and seeking to bring up six children in a Christian manner. $\mathrm{He}$

${ }^{79}$ Luther, "Parents Should Neither Compel nor Hinder the Marriage of Their Children," 388.

${ }^{80}$ Luther, "The Estate of Marriage," 47.

${ }^{81}$ Lindberg, "Luther and the Family," 138.

${ }^{82}$ Roland H. Bainton, Here I Stand: A Life of Martin Luther (Nashville: Abingdon, 1950), 384. 
wrote a preface for the publication of Johann Freder's $A$ Dialogue in Honor of Marriage in 1545, just a year before his death, ${ }^{83}$ thereby demonstrating that marriage and family was his lifetime concern. All these show us that Luther was not merely a critical theologian or uncompromising church reformer, but a faithful pastor who was sensitive to people's daily concerns and problems.

${ }^{83}$ Hendrix, "Luther on Marriage," 171. 


\title{
The Priesthood of All Believers in Africa
}

\section{CONRAD MBEWE}

\begin{abstract}
Protestant churches in Africa have come under scrutiny from political leaders due to the abuse that citizens in the churches suffer at the hands of their leaders. This is in part due to the loss of the doctrine of the priesthood of all believers taught in the Bible and rediscovered during the Protestant Reformation in the sixteenth century. We trace the discovery of this doctrine in the Reformation, its application to Africa, and its current absence, and we call church leaders to teach this truth afresh to God's people.
\end{abstract}

$\mathrm{t}$ is not an overstatement to say that one of the greatest challenges facing the Christian church in sub-Saharan Africa today is the need to reclaim the doctrine of the priesthood of all believers. If believers in Africa could appropriate afresh in faith and practice this great doctrine that was rediscovered during the Protestant Reformation, it would bring a check on the current spate of "prophets" who are wreaking havoc in many churches. For instance, here are two stories from local newspapers in Zambia.

Police in Chipata have arrested two clergymen of a named church for indecently assaulting two girls while praying for them. The Zambian News Agency and Information Services report from Chipata that Eastern Province Deputy Police Commissioner Alfred Nawa confirmed the incident in an interview today. The [Deputy Police Commissioner] named the duo as Prophet Misheck Ngalande and Pastor 
Ben Banda.... Mr. Nawa says that the two were arrested yesterday, but the incident happened on April 25, this year, in the hills of Nabvutika compound, where the suspects were conducting prayers. He said one of the victims fled from the scene and reported the incident to the police. The duo has been charged with indecent assault and will appear in court soon (May 8, 2013).

A Lusaka based clergyman, who in 2012 impregnated at least ten women among his followers, has finally been divorced by his long-suffering wife. Bishop Emmanuel Chika of the Restoration Deliverance Church was sued by his wife for divorce after his "skirt evangelism" was published in the media in September 2012. His wife, Alice Kasonda, decided to end the marriage after seeing for herself the number of children the "pastor" has sired within the church. At the Chelstone local court, the wife also revealed the witchcraft Chika uses (July 8, 2013).

There are similar stories from South Africa. There was the news of a pastor who told his congregation to go outside and eat grass - and they did! Another pastor has recently been reported to give his church members snakes and mice to eat. And even more recently a pastor sprayed the insecticide DOOM on his congregants as a way of delivering them from whatever their problem was.

These are not the only cases that are rocking the church in Africa. The cases are so many that governments all across the continent are beginning to come up with legislation to arrest this trend. What is it that makes believers so vulnerable? It is that they sincerely believe that these pastors have access to God that they themselves or their fellow believers do not have. These "men of God" claim to be able to enter the spiritual realm and see the source of the difficulties that believers who come to them for help are going through. They also claim to have prayers that are powerful to bring about breakthroughs in the lives of those who come to them for help. What does the Bible teach about this issue?

\section{The Biblical Teaching}

The best place to start is in Jeremiah, where a major difference is announced between the old and new covenant:

Behold, the days are coming, declares the LORD, when I will make a new covenant with the house of Israel and the house of Judah, not like the covenant that I made with their fathers on the day when I took them by the hand to bring them out of the land of Egypt, my covenant that they broke, though I was their husband, declares the LORD. But this is the covenant that I will make with the house of Israel after those days, declares the LORD: I will put my law within them, and I will write it on their hearts. And I will be their God, and they shall be my people. And no longer shall each one teach his neighbor and each his brother, saying, "Know the LoRD," for they shall all know me, from the least of them to the greatest, declares the LoRD. For I will forgive their iniquity, and I will remember their sin no more. (Jer 31:31-34 Esv) 
This pivotal text is quoted in the New Testament in order to make the point that one of the major differences between the New Testament and the Old is in the office of priest. In the Old Testament, there was an exclusive priesthood in the line of the tribe of Levi (Exod 40:13 and Num 1:47-54). They stood between God and his people. They alone worked in the temple and took sacrifices from the people to their God and, consequently, brought God's favor from God back to his people. Everyone else was warned to keep away. When King Saul made the mistake of offering a sacrifice because Samuel had delayed in coming to him, he was roundly rebuked. Being a king did not allow him a backdoor entry into the priesthood (1 Sam 13:8-15a).

However, when Jesus Christ came, and when he died, he removed this barrier (Rom 5:1-2). This was powerfully signified in the tearing of the curtain in the temple from top to bottom when Jesus breathed his last on the cross (Luke 23:45-46). The way into the holy of holies (also known as the most holy place) was now open. Any child of God could enter God's presence through the sacrifice of Christ, which he made as our high priest once for all when he died on the cross to pay the price for all our sins (Heb 10:12). There is no need for priests any more. Jesus has gone into the real holy of holies in heaven with his own blood as our high priest. That is the argument of the book of Hebrews (see especially Heb 9:11-12). It was written to show those Jewish believers being tempted under intense persecution to go back to Judaism that they were going back to something that was now obsolete. The earthly temple was now redundant because Jesus had gone into the real temple in heaven with his own blood. The priests were also now redundant because all believers were now priests.

As God said through Jeremiah, "No longer shall each one teach his neighbor and each his brother, saying, 'Know the LORD,' for they shall all know me, from the least of them to the greatest, declares the LORD." The Holy Spirit dwells in each regenerate child of God, enabling all to know God at a personal level. This does not negate the need for teaching, but it means that all can sense whether what we are being taught about God and his ways is true or false. We can read our Bibles and understand what is being taught there. We do not need to be blind followers of others. We can actively participate in spiritual things and be stewards of the church of the Lord Jesus Christ on earth. We know the Lord!

In Exodus 19:6, God said to the people of Israel that he had rescued from Egypt, "You shall be to me a kingdom of priests and a holy nation." This was later fully applied to the New Testament church in passages such as 1 Peter 2:5, 9 and Revelation 1:6; 5:10; 20:6. All believers are to offer spiritual sacrifices acceptable to God through Jesus Christ because all have 
access to God through him (Eph 2:17; Rom 5:2). Sacrifices are in terms of a broken heart, prayer, and praise. As Albert Mohler puts it,

the doctrine of the priesthood of believers thus affirms the right of every believer to fellowship with God through Christ, and the obligation of every believer to be a fully functioning member of a congregation, exercising Christian discipleship among the fellowship of other believer-priests. ${ }^{1}$

This is the biblical teaching of the priesthood of all believers. Indeed, it is a most liberating teaching. It causes believers to prayerfully and actively use their minds to responsibly seek God and his will for them and for their church, rather than mindlessly trusting someone else to do that for them.

\section{The Teaching Lost in the Medieval Era}

Sadly, despite the clarity in the Bible concerning the priesthood of all believers, this teaching was largely lost in the medieval era through the emergence of a priestly caste in the church. This happened through the erection of a barrier between ordinary believers (the laity) and those who ministered God's word to them (the clergy). The Lord's Supper became a sacrifice that the priests were enacting. Sacerdotalism was born, and ministers claimed supernatural powers to dispense the grace of God through the sacraments, which gave them control over the laity. W. J. Moulder writes,

Clement, writing in the last decade of the 1st cent., speaks of the Christian ministry as high priest, priest, and Levite (1 Clem. 40-44); the Didache (13:3) calls Christian prophets "your high priests" and refers to the Eucharist as a sacrifice. ... About A.D. 200 Tertullian (De baptismo 17) and Hippolytus (Preface to Refutatio omnium haeresium) in the West called Christian ministers "priests" and "high priests."

The Bible was kept in the Latin language, which only the priests and the few educated people could understand. Consequently, ignorance of the Bible's content became widespread. The priests alone knew its contents. The common understanding - especially in the Roman Catholic Church, even until the time of Vatican II - was that the ordinary people would be confused and misled if they were allowed to read the Bible in their own mother tongue. Thus any attempt to translate the Bible into the language of the common man was opposed, and those who tried to do so were persecuted

1 R. Albert Mohler Jr., "Priesthood of Believers," in Chad Brand et al., eds., Holman Illustrated Bible Dictionary (Nashville, TN: Holman Bible Publishers, 2003), 1328.

2 W. J. Moulder, "Priesthood in the NT," in Geoffrey W. Bromiley, ed., International Standard Bible Encyclopedia (Grand Rapids: Eerdmans, 1979-1988), 3:965. 
and killed. The Latin Vulgate remained the sole translation of the Bible allowed to be read in churches for many years.

The priests alone could administer the sacraments, and the people went to them to have their sins absolved. They were seen as having a special relationship with God that no one else in the church had. At least that was the claim. The people of God simply had to believe what they were told by those who were in this unique category and were hearing directly from God - the priests. The people also went to them for all the sacraments-baptism, the Eucharist, marriage, and so on. Only the priests, and in some cases only the bishop, could administer these.

This dependence on the priests was unhealthy and unbiblical. The people of God, though inside the church, were alienated from the church in terms of being responsible for what was going on there. They were merely guests and visitors in need of being ministered to by those who had this special relationship with God. Once corruption entered the hierarchy, there was no safeguard against it among the people (the laity). This was what happened in the period leading to the Reformation in the sixteenth century. Thankfully, in the Reformation the doctrine of the priesthood of all believers was rediscovered and faithfully taught and applied.

\section{The Teaching Rediscovered in the Reformation}

One of the greatest battles to be won during the Protestant Reformation was that of liberating the people of God from the stranglehold and domination of the Roman Catholic clergy. A major weapon in the armory of the Reformers was a return to the biblical doctrine of the priesthood of all believers. According to Jon Wood,

As early as 1523 , Luther and Zwingli made similar arguments in the matter. A broad range of theological, social, and political ramifications quickly became apparent. Local communities often became more empowered in matters of church life and discipline, even to the theoretical extent of dismissing corrupt clergy and electing suitable ministers of their own. ${ }^{3}$

The newfound freedom would have resulted in chaos were it not for the efforts made by magisterial Reformers like John Calvin who instituted mature church leadership led by lay elders in order to guide the people of God.

3 Jon Wood, "Priesthood of Believers," in David M. Whitford, TE T Clark Companion to Reformation Theology (New York: T\&T Clark, 2012), 443. 
The Reformers, at great risk to their lives, translated the Bible into the common language of the people. They strongly believed that any regenerate child of God with the Holy Spirit could understand the Scriptures by simply reading them and thus come to know the mind and will of God for their lives and for the church of which they were a part. Indeed, as William Tyndale said to an English cleric, "If God spare my life, ere many years pass, I will cause a boy that driveth the plow shall know more of the Scripture than thou dost." Or as Erasmus writes in the preface of his Greek NT, "I would to God that the plowman would sing a text of the Scripture at his plow and that the weaver would hum them to the tune of his shuttle." ${ }^{4}$ Thus, the Reformers translated the Scriptures and made them available to anyone. With the souls of believers thus liberated, there was an exodus from the Roman Catholic Church into what has since come to be known as Protestant churches. Alan Cairns writes,

It was one of the great accomplishments of the Reformation to sweep away this monstrous system and to proclaim that sinners have direct access to God through the merits of Christ to obtain from him directly the saving grace they need, and that saints have unrestricted access to the throne of grace, without any sacerdotal intrusion by any man. ${ }^{5}$

\section{The Implications of This in Africa}

As Christianity came to Africa, the various Protestant missionaries who brought the Christian faith would have known the doctrine of the priesthood of all believers and would have taught it to their new converts. Christians would have known even in those early years that they have direct access to God through the finished work of his Son on the cross. However, the missionaries applied the doctrine of the priesthood of all believers slightly differently in their churches, depending on their form of church government. So, for instance, those churches that had an episcopal form of church government (e.g., the Anglicans) would involve the laity less than those with a congregational form of church government (e.g., the Baptists), and those with the Presbyterian form were somewhere in the middle.

In an indirect way, when Protestant Christianity was brought to Africa in the nineteenth and twentieth centuries, the doctrine of the priesthood of

4 As quoted by Tony Lane in "A Man for All People: Introducing William Tyndale," Christian History 6 (16). 4 (1987): 7. Cf. Desiderius Erasmus, "An Exhortation to the Diligent Study of Scripture," Unio cum Christo 2.2 (October 2016): 19.

5 Alan Cairns, Dictionary of Theological Terms (Greenville, SC: Ambassador Emerald International, 2002), 343. 
all believers is what led the overseas missionaries to start involving new indigenous converts in the administration of local church affairs and to hand over leadership of the churches to indigenous lay leaders. Those missionaries who recognized this doctrine at a practical level, believing that the same Holy Spirit who guided the church overseas would also guide the church in Africa, acted without waiting for indigenous leaders to reach the level of understanding that their own church leadership overseas had reached.

Those missionaries who recognized the doctrine of the priesthood of all believers only at an intellectual level were more hesitant and ended up with serious power struggles between themselves and indigenous converts. Even where they handed over some church power, they still preferred to remain on top of the leadership structures. The understanding of the indigenous converts of their equality with missionaries arising from the priesthood of all believers propelled them to demand an equal say in church life, resulting in leadership conflicts. This has been a common phenomenon across Africa in the last fifty to sixty years.

If during the Reformation the teaching of the doctrine of the priesthood of all believers resulted in social and political upheavals, it was the same in Africa. Since many of the Pan-African political leaders in the middle of the twentieth century were educated in mission schools, the teaching of universal priesthood had social and political ramifications. Indirectly, it gave rise to the fight for political independence that took place in many nations across Africa. Missionaries were also feeling the pressure being felt by colonial masters. Those missionaries who were hanging on to church power were seen as enemies of church progress. Many were forced to leave the field and go back to their countries for safety and with real frustration.

\section{The Teaching Lost Again in Africa}

If we are to understand how the doctrine of the priesthood of all believers has been largely lost in Protestantism in Africa, we must go back about a hundred years to the Pentecostal movement that started with the Azusa Street phenomenon in California in the USA. This movement emphasized the extraordinary gifts of the Spirit, speaking in tongues, miraculous healings, and prophecy. It taught that every Christian should undergo a "baptism of the Spirit" as a postconversion experience, the proof of it being speaking in tongues and empowerment for Christian service.

When missionaries first brought Christianity to the African continent, some African prophets with charismatic powers arose in their ranks. These included prophets like William Wadé Harris of the Gold Coast (now Ghana), 
Garrick Sokari Braide of the Niger Delta, Simon Kimbangu of the Congo, Isaiah Shembe of South Africa, Lenshina of Northern Rhodesia (now Zambia), and others. The missionaries did not accept them in the churches because they were syncretistic, mixing Christianity with African traditional religions. Hence, by the middle of the twentieth century, these prophets were few and were outside the mainline churches.

There has been a change in Protestant Christianity in the last fifty years all across Africa. Many overseas missionaries handed over the denominations in the 1950s and 1960s to indigenous leaders even as the colonial masters were handing over political leadership to indigenous political leaders. This was good and a positive thing, but in many cases the new leaders were not ready to handle the challenges that claims to the miraculous gifts would bring to the church.

The Pentecostal movement (the Assemblies of God, Apostolic Faith Mission, and the Full Gospel Church) arrived from overseas in the 1960s and 1970s teaching Spirit baptism with the evidence of tongues and calling people to be prayed for. There were also prophecies, visions, healing, deliverances, and miracles in general. Initially these remained within the Pentecostal denominations. However, the mainline churches began to be affected as some of their members aspired to see similar phenomena in their churches. When they resisted the change, many of them lost members who joined the Pentecostal denominations.

By the 1980s a neo-Pentecostal (or Charismatic) movement grew out of the splits. Indirectly, this was a fruit of an understanding of the priesthood of all believers, not as a well-articulated doctrinal position but rather as a culture of "we are the church." If all believers can understand the Bible and if all have access to God through Christ's finished atoning work on the cross, why should they be entrapped in established Pentecostal denominational structures? After all, the major Pentecostal denominations also started as independent churches when their founders left established churches that were not responding positively to the Pentecostal phenomenon. So in the last few decades this "we are the church" culture has resulted in many independent Charismatic churches mushrooming across Africa, especially in the major cities.

This is where the problem has begun to be evident-in the new churches. The neo-Pentecostal or Charismatic movement, which has become widespread in Africa and across the world, has tended to make each congregation a one-man show. The universal emphasis is on the "man of God" who is anointed with divine power to deliver people from such things as delay in marriage, joblessness, miscarriages, divorce, poverty, and disease. Often he 
is also the founder of his church, having come up with the church's name, the meeting place and times, the structure, and the other leaders, and the church's offerings go to him. In many cases, this "man of God" makes his wife the second in command.

This has led to the loss of the priesthood of all believers at two levels. At the first level, it is the alienation of the ordinary church members from church responsibility and ownership. They have no say in any major decisions in the church, not even how the money they give in church is to be spent. The clergy/laity divide is very clear. Its conspicuousness is made more evident because on the clergy side there is only one person-the "man of God"- and everyone else is for all practical purposes on the laity side. As the saying goes, "power corrupts and absolute power corrupts absolutely," and so in many of these churches scandals in the lives of the "men of God" have come out, and church members have been helpless to do anything about it. They have instead been told that if they do not like what is going on they should be the ones to leave. "This is my church," the embattled leader often says. So, these leaders are above church discipline while they themselves can discipline anyone. This is certainly a loss of the priesthood of all believers.

At the second level, the loss of the priesthood of all believers is seen in the alienation of ordinary church members because they realize that they too have as much access to God as the "man of God." Whereas at the beginnings of the Pentecostal movement the extraordinary gifts were supposed to be spread across the membership of the church, the neo-Pentecostal movement inadvertently embodies all of them in the "man of God"-except, perhaps, the gift of speaking in tongues. He is the one God talks to about the future of the church and the cause of problems in the lives of those who go to him for help. He is the one who prophesies. He is the one whose prayers are powerful to the pulling down of strongholds and whose prayers bring breakthroughs (cf. 2 Cor 10:4). All other church members can only bring the needy to the "man of God" to be prayed for. The common language in such church circles is, "Come to my church. My pastor prays for people with such problems." Ordinary church members have lost the conviction that because every believer's access to God is mediated through the finished work of Jesus Christ on the cross they have as much access to God as their pastor. This is certainly a very serious loss of the priesthood of all believers.

Whereas the Pentecostal movement has spread to all continents, the loss of the priesthood of all believers is especially critical in Africa and Asia. This is because of the close proximity of believers on these two continents to the spiritual world outside the Christian faith. Thus a new sacerdotalism has 
been born, with a new generation of pastors calling themselves by names such as apostles and prophets, who are claiming to have supernatural powers and are bringing God's people under their unbiblical control.

This is where the abuse I referred to at the start of this article is found. God's people, not knowing that they do not need a human intermediary and not knowing that they have equal access to God through Christ, go to "apostles" and "prophets" to be prayed for so that they can be delivered from whatever is depriving them of joy. They go to them in precisely the same way that their relatives in the village go to the witch doctors. They believe everything they are told by the "men of God." They accept any method these men tell them to use in order to be delivered-including giving money and even having sex with them.

How can African believers be so gullible? It is because of traditional African religious spirituality. Africans are not natural atheists and have always believed in some divine being whose benevolence brings good fortune in human life. However, African religious belief is that this divine being is far away. Between him and us lie two impregnable layers of spirits - the spirits of those who have already died and the angelic beings. The average person cannot break through these layers to get to God and receive his blessing. A mediator is needed to break through these layers. Outside the Christian faith the village witch doctor rules and claims to have such powers. In the Christian church the "man of God" has taken the place of the village witch doctor. Due to the fact that both situations are built on the belief system of African religious spirituality, African Christians easily play into the hands of those who give them the impression that they have this exclusive access to God and the spiritual realm that they themselves do not have. They do not realize that the God who was far away from them because of their sin has now been brought near through the cross of Christ. Christ is in God's presence now as their mediator. They do not need another mediator. They have access to God and so do other ordinary church members who can also pray for them. Somehow the ongoing need for another human being who has been given power to break through the impregnable layers lurks at the back of the minds of Africans - whether converted to Christianity or not. This is what makes African believers gullible. The only way they can be guarded against this is for the doctrine of the priesthood of all believers to be taught again in the churches all across the continent. 


\section{The Need to Restore This Teaching}

It is our prayer that church leaders in Africa may proclaim to their followers the doctrine of the priesthood of all believers and safeguard them from the darkness that has began to engulf Protestantism at the start of the twentyfirst century. That political authorities are beginning to say, "Enough is enough!" should be a cause of serious concern for all of us. We need to put our house in order before others do it for us. When political leaders start meddling with the church, the church loses its prophetic role in society, as history has shown. We must not let this happen.

This abuse of God's people will only be arrested by a full-orbed display and restoration of the biblical teaching of the priesthood of all believers in the churches across the continent of Africa. It is a clear teaching in the Bible, promised in the Old Testament and fulfilled in the New Testament after the death of the Lord Jesus Christ. It is the right of all the people of God and results in stronger churches. The five-hundredth anniversary of the Protestant Reformation is a good time for us to dust off this teaching and put it on display for all God's children to see and apply to their lives and the lives of their churches. 


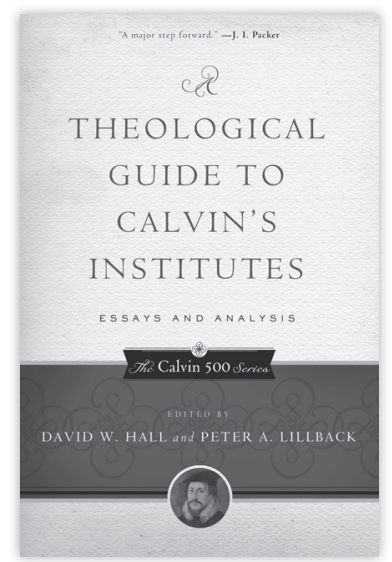

A Theological Guide to Calvin's Institutes edited by David W. Hall and Peter A. Lillback

978-1-62995-194-2 | p | \$22.99

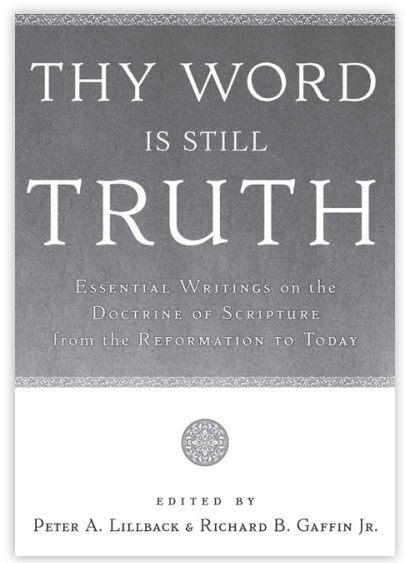

Thy Word Is Still Truth edited by Peter A. Lillback and Richard B. Gaffin, Jr. 978-1-59638-447-7 | h | \$59.99

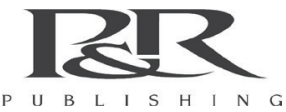

A long-needed work, this volume serves as the natural companion to Calvin's magnum opus for classes, students, pastors, and others.

"A very valuable volume, which I commend with enthusiasm. For making Calvin known today as well as once he was, and in every age deserves to be, this really is a major step forward."

\section{-J. I. PACKER}

One of the hallmarks of

Westminster Theological Seminary since its beginning in 1929 has been a high view of Scripture that reflects the historic Reformed theological and confessional tradition. Thy Word Is Still Truth confirms that Westminster still holds this high view.

"A five-hundred-year library of thoughtful, faithful reflection on the nature of biblical truth [in] a single, indispensable volume."

\section{-PHILIP G. RYKEN}




\section{Do Judaism, Islam, and Christianity Worship the Same God? A Reformed Theological Perspective}

\section{PHILIP TACHIN}

\section{Abstract}

It is debated whether Judaism, Christianity, and Islam worship the same God. That they share the same roots in Abraham, the father of faith, makes some, including Christian scholars, conclude that they worship the same God. The question turns on the real substance of worship and its approval by God. Drawing from the classical Reformed view, we make a logical and exegetical argument that Judaism, Christianity, and Islam may have shared the same broad categories about their supreme deities, but conclude that they actually do not worship the same God. That true worship of God is Trinitarian and Christ centered, which is unique about Christianity, makes it impossible to admit that the three religions worship the same God.

\section{Introduction}

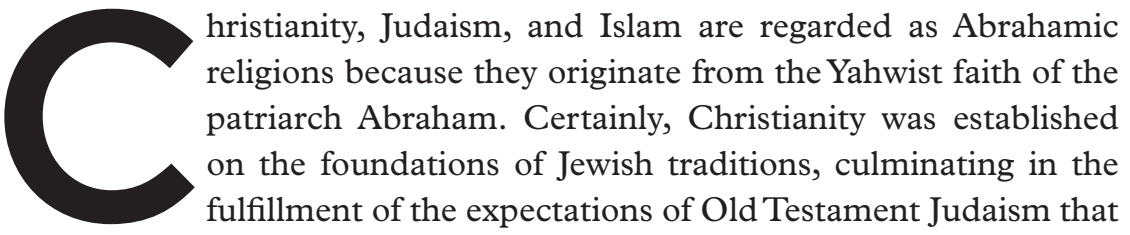


centered on the divine Messiah, whom Christians identify as the person of Jesus Christ. This gave rise to a variety of interpretations against traditional Judaism, which rejected Jesus as the Messiah. Islam also adapted itself to the Judaic traditions with additional material but diverged significantly in its eschatological interpretations, centering on Muhammad as the final and greatest prophet, though not considering him a savior. Many believe that the three monotheistic religions worship the same God, though in different ways. As long as they have existed, there have been tensions and conflicts, and some scholars believe that this is owing to the stark differences between their beliefs. ${ }^{1}$

Currently, the global community is moving into a dangerous time, where religious persecution and oppression result in the torture of religious minorities, and this will affect the global economy, politics, and social ethics. Some believe that hostilities could be minimized if it were accepted that all three religions worship the same God. However, this perspective may not be helpful, as historical evidence has shown otherwise. The question is, Can the understanding that the same God is worshiped, though in different ways, reduce the tension between adherents of the three religions? Our thesis is that it is possible that Christians, Jews, and Muslims may have the same deity in view, but not all their worship is acceptable to him. Therefore, they cannot be worshiping the same God. God determines what acceptable worship is, and all must unite under such worship; however, since it is impossible for this unity to be obtained in this present life, religious conflicts will persist till the end of time. The nature of the question is not about the place, styles, and rituals of worship but about the definitive redemptive controlling principle of worship. The approach to this question is academic, confessional, and practical.

\section{Belief in the Same God Is Not a Solution to Religious Conflicts}

The basic concern of those who propose that Christians, Jews, and Muslims worship the same God is to minimize religious tensions and conflicts. ${ }^{2}$ This has led some Christian theologians to compromise historic confessions to

1 Will Durant chronicles the religious divisions that bedeviled Islam and Christianity during the Crusades, which were motivated by political and economic interests. See Will Durant, The Age of Faith: A History of Medieval Civilization-Christian, Islamic, and Fudaicfrom Constantine to Dante, A.D. 325-1300 (New York: Simon \& Schuster, 1950), 588-92.

2 Albert Mohler, "Do Christians and Muslims Worship the Same God?," Billy Graham Evangelistic Association, http://billygraham.org/decision-magazine/december-2013/do-christiansand-muslims-worship-the-same-god/. 
accommodate Islam, with the hope that this will create peaceful relationships and tolerance between Christians and Muslims. MiroslavVolf expresses this concern when he states that Christians and Muslims "are at each other's throats, if not literally, then in their imaginations. And we need to find ways we can believe peacefully together." "' The desire is to shape the attitudes of the Abrahamic religions in order "to build a flourishing democratic society" through enforcing "a common set of fundamental values." Volf points to the "similarity in descriptions of God" of Christians and Muslims to demonstrate "the claim that [they] worship the same God" as well as the "similarity in God's commands in the two faiths to reinforce that claim." ${ }^{5}$ Muslims and Christians have "a common God" and "a common eternal destiny"; ${ }^{6}$ and most likely present "two versions of the same thing"; 7 exclusive tendencies should be removed so the two faith communities can live without hostility.

But is this realistic? Must we have the same God, houses, cars, food, clothes, language, and so forth, in order to live harmoniously? Volf's argument against exclusivism loses its force in the context of the differences in human existence. He makes, however, the important suggestion that all religions should be deeply concerned with seeking to destroy the "religious motivation to violence" and to encourage "motivation to care for others" in the pursuit of the common good of all. ${ }^{8}$ Peter Kreeft argues that while we must disavow some aspects of Islam, there are good things that we can also emulate without necessarily conflating the differences between Christianity and Islam. ${ }^{9}$ It might be good to ask at this juncture whether Jesus could have accepted Islam as a true religion and another way to God. Would it not contradict his claim that he is "the way, and the truth, and the life" and his

3 Mark Galli, interview of Miroslav Volf, "Do Muslims and Christians Worship the Same God?," Christianity Today, http://www.christianitytoday.com/ct/2011/april/muslimschristianssamegod.html.

4 Miroslav Volf, introduction to DoWeWorship the Same God? Fews, Christians and Muslims in Dialogue, ed. Miroslav Volf (Grand Rapids: Eerdmans, 2012), viii.

5 Miroslav Volf, Allah: A Christian Response (New York: HarperOne, 2012), 97 (emphasis his). Volf is influenced at this point by Nicholas of Cusa, to whom he appeals a number of times. Nicholas was also motivated by the Islamic invasion of Constantinople to seek ways of mitigating the attacks. See James E. Biechler and H. Lawrence Bond, eds., Nicholas of Cusa on Interreligious Harmony, Texts and Studies in Religion 55 (Lewiston, NY: Mellen, 1990), xii-xiii. On the side of concurrence in this debate are Peter Ochs, Miroslav Volf, Reza Shah-Kazemi, Alon Goshen-Gottstein, Amy Plantinga Pauw, Christoph Schwöbel, and Denys Turner, in Do We Worship the Same God?

6 Volf, Allah, 188.

7 Ibid., 191.

8 Ibid., 262.

9 Peter Kreeft, Between Allah and Fesus: What Christians Can Learn from Muslims (Downers Grove, IL: InterVarsity Press, 2010), 10-12. 
words "no one comes to the Father except through me" (John 14:6 ESV)? Moses prophesied about a prophet coming after him (Deut 18:15; cf. Acts 3:22), and no subsequent prophet after him never claimed to fulfill this prophecy; Jesus not only fulfilled the prophecy, but also never prophesied that anyone would come after him.

On the other hand, Volf notes that when it comes to a "description" of God, one must deal with such fundamental differences as the concept of the Trinity in Christianity, which is absent in Islam and latent at best in Judaism. He claims that Christians, Jews, and Muslims worship the same God, and it is in their understanding of him that differences arise. Volf looks at what appears to be the cause of the similarities and differences. According to him, orthodox Christians and mainstream Muslims believe in one supreme deity. Muhammad himself claimed that Allah is the Jewish synonym of Yahweh with all similar attributes, ${ }^{10}$ and one fundamental teaching from God that should drive Christians and Muslims to learn how to live peacefully together is the command to love one's neighbor.

Denys Turner argues, in line with Volf, that a common principle exists concerning God in all three religions: "What links the end with the beginning is a single, unbroken, spatiotemporal process of change, or, as we might say, a single narrative of space and time coordinates." that God is the central principle of all reality, this does not imply that God functions in the same way in the three worldviews.

The question is not about the names of God, such as Allah and God or Yahweh, as some propose for the differences of the deity in question. ${ }^{12}$ In other tribal religions, though there are a variety of deities, one supreme deity is acknowledged, in whom Christians, Muslims, and Jews believe. So the differences properly speaking are not so much about the names of God as about right worship. This is where the difference lies. Muslims believe in the way of worship that Muhammad showed them, and Judaism holds to the prescriptions of the Torah. But for Christians, Jesus Christ clearly states that he is the way, the only way to God. Even though Pope Gregory VII held that Muslims and Christians worship the same deity as the basis for his argument in favor of peaceful coexistence, the majority of Christians today or even in his own time did not hold his view. ${ }^{13}$

\footnotetext{
${ }^{10}$ Durant, Age of Faith, 184.

11 Denys Turner, "Christians, Muslims, and the Name of God: Who Owns It, and How Would We Know?,” Do We Worship the Same God?, 18.

${ }^{12}$ Volf, Allah, 81-84.

${ }^{13}$ John Bohnstedt, "The Infidel Scourge of God: The Turkish Menace as Seen by German Pamphleteers of the Reformation Era," Transactions of the American Philosophical Society 56.9 (1968): 42. He was citing Surah Ali 'Imran, 3:48.
} 
John Bohnstedt argues that Muhammad also "generously accepts the Hebrew and Christian Scriptures as divinely revealed," and accordingly, "God has given man 104 revelations, of which only four have been preserved - the Pentateuch to Moses, the Psalms to David, the Gospel to Jesus, the Koran to Mohammed; whoever rejects any of these is, in Mohammed's view, an infidel. However, the first three suffered such corruption that they can no longer be trusted; and the Koran now replaces them." ${ }^{\prime 14}$ Charles Kimball also argues, "Jews, Christians, and Muslims are talking about the same deity." 15

Nabeel Qureshi acknowledges the "enormous tensions in ChristianMuslim relations." ${ }^{16} \mathrm{He}$ rejects claims that Christians and Muslims worship the same God on the basis of the confessions that define the distinctiveness of the Christian religion. Islam and Christianity view the oneness of God differently. The testimony of the Christian Scripture, which reveals God as three persons in one essence, forms the basis of the understanding of the Christian God. Qureshi's response to this matter is interesting: "Muslims and Christians do not worship the same God, but given the complexity of the matter we all ought to stop demonizing those who disagree with us." ${ }^{17}$

But belief in the same God does not necessarily amount to the same belief in the particulars of God, which consequently renders such claims ambiguous. In Christianity, as in Islam and Judaism, various sects have emerged because of divergent views of the one God professed. Historical records show that sects in the three religions were often in conflict. In Judaism, "there were pro-Babylonians and pro-Egyptians," "pro-Persians and pro-Greeks," "pro-Egyptian Hellenizers and pro-Seleucid Hellenizers" and "pro-Romans and pro-Seleucids," and in the New Testament, there were "Pharisees, Sadducees, Essenes and other sects." ${ }^{18}$ Similarly, "the Christian church as a whole was divided into five apostolic sects at the beginning of Islam, located in Rome, Antioch, Constantinople, Jerusalem, and Alexandria." ${ }^{19}$ This situation is replicated in Nigeria, as Islamic sects contradict themselves on textual interpretations, which often results in violence. This

\footnotetext{
${ }^{14}$ Ibid.

${ }^{15}$ Charles Kimball, When Religion Becomes Evil (San Francisco: Harper \& Row, 2002), 50.

${ }^{16}$ Nabeel Qureshi, "Do Muslims and Christians Worship the Same God?," Ravi Zacharias International Ministries, http://rzim.org/global-blog/do-muslims-and-christians-worship-thesame-god.

${ }^{17}$ Ibid.

${ }^{18}$ George Wesley Buchanan, The Book of Daniel (Eugene, OR:Wipf \& Stock, 2005), 450.

${ }^{19}$ Jane Smith, "Muslim-Christian Relations-Historical and Contemporary Realities," Oxford University Press, http://religion.oxfordre.com/view/10.1093/acrefore/9780199340378. 001.0001/acrefore-9780199340378-e-11.
} 
fragmentation is responsible for violent crises that have occurred in Afghanistan, Iraq, Libya, Egypt, and Syria. The divergent interpretations and applications of Islamic texts have always exacerbated tensions and violence between Islam and Christianity.

The Roman Catholic Church embraces the God of Islam to be one with its confession: "The plan of salvation also includes those who acknowledge the Creator, in the first place amongst whom are the Muslims; these profess to hold the faith of Abraham, and together with us they adore the one merciful God, mankind's judge on the last day." ${ }^{20}$ The implication of this is that Catholicism has no business evangelizing Muslims. Yet there are inconsistencies in Catholic theology when it professes that

true prayer can arise from worshippers who have wild misunderstandings of God. Indeed, both testaments of sacred scripture contain many examples of "unorthodox" people voicing prayers to the true God. This happens because all prayer somehow emerges from and through the influence of the Holy Spirit, "who blows where he wills." The Holy Spirit operates within religious communities whose members misunderstand or fail to grasp the fullness of divine revelation. ${ }^{21}$

The problem with this view is the place of the Holy Spirit in Christianity and Islam. In Christian theology, the Holy Spirit is understood to be the third person in the Trinity, whose function is to regenerate hearts and lead them to the saving knowledge of God in Christ. Scripture testifies to this truth: "Those who are in the flesh cannot please God" (Rom 8:8 Esv). Furthermore, "The person without the Spirit does not accept the things that come from the Spirit of God but considers them foolishness, and cannot understand them because they are discerned only through the Spirit” (1 Cor 2:14 NIv).

Since Islam does not believe in the Trinitarian God of Christianity, how does this Catholic view explain actions in Islam with relation to the Holy Spirit? Does the Holy Spirit inspire Islamic violence? The Holy Spirit operates with special graces and gifts, and the only ground where they are eminently present is in Christ because "wheresoever Christ had been soundly and thoroughly preached the visible graces did also appear."22

${ }^{20}$ Michael Kerper, "Do Christians, Jews and Muslims All Pray to the Same God?," Parable (May/June 2016): 10, Catholicnh.org, http://www.catholicnh.org/assets/Documents/CatholicFaith/KerperFAQ/SameGod.pdf, emphasis mine. He was answering an enquiry from one of his members and citing Catechism of the Catholic Church, 841. I think the word "us" here refers to the Catholic Church rather than the entire Christian church.

${ }^{21}$ Kerper, "Do Christians, Jews and Muslims All Pray to the Same God?," 11.

${ }^{22}$ John Calvin, Commentary on the Acts of the Apostles (Albany, OR: Ages Digital Library, 1998), 632. 


\section{Do All Three Religions Worship the Same God?}

The question is not whether Christianity, Judaism, and Islam worship one God but rather whether they worship the same God. An affirmative answer depends on the worship of the three religions being acceptable to God. It is false comfort to claim that God accepts all human ways of approaching him. ${ }^{23}$ There are surely many ways, but not all ways are true; the Psalmist presupposes many ways, some of which are false. There is one definite way, indicated by the singular construct and absolute: "I have chosen the way of faithfulness" (Ps 119:30 ESV). This is certainly a reference to worship of Yahweh in the context of other religions that surrounded Israel and constantly attracted the chosen people of God.

The religious conflict between Cain and Abel in Genesis 4 provides some insights into this question, since Cain and Abel represent two religions. It would appear prima facie that they worshiped the same God, but closer examination suggests otherwise. The God who accepted Abel's worship rejected Cain's worship, so it is right to argue that they had the same divine object in view. But that God rejected Cain's worship shows by implication that he was not worshiping that same God. Rather, he was worshiping his own graven image, the idol of his heart, so his God was not the same God of Abel. To worship God truly is to turn away completely from idolatry. Since religion is essentially a matter of the heart, Cain's heart was not right with God, "for he lacked a right disposition toward God," ${ }^{4}$ which was the reason for his rejection, whereas Abel's heart was right with God, and he was accepted (Heb 11:4; cf. 1 John 3:12; Jude 11). Accordingly, ancient Hebrew worship laid emphasis on the "heart, motive and disposition," which is the seat of religion..$^{25}$ Gordon Wenham adopts the generally accepted view,

${ }^{23}$ Pluralist Christian philosophers such as John Hick and Paul F. Knitter have devoted extensive scholarly work to the defense of this position. They even believe that all other religions apart from the three in view here worship the same God and all their worship is acceptable to God. See John Hick and Paul F. Knitter, eds., The Myth of Christian Uniqueness (Maryknoll, NY: Orbis Books, 1998); John Hick, "Jesus and the World Religions," The Myth of God Incarnate, ed. John Hick (Philadelphia: Westminster, 1977); "Incarnation and Atonement: Evil and Incarnation," Incarnation and Myth:The Debate Continued, ed. Michael Goulder (Grand Rapids: Eerdmans, 1979); "Whatever Path Men Choose is Mine," Christianity and Plurality, ed. Richard J. Plantinga (Oxford: Blackwell, 1999). I have refuted their position in Philip Tachin, "A Critique of John Hick's Christology and Reaffirmation of the Exclusiveness of Christ," International Fournal of Orthodox Theology 2.2 (2011): 112-31, http://orthodox-theology.com/ media/PDF/IJOT2-2011/08-tachin-hick.pdf.

${ }^{24}$ Arthur B. Fowler, "Cain," The New International Dictionary of the Bible, ed. J. D. Douglas et al. (Grand Rapids: Zondervan, 1987), 181.

${ }^{25}$ Scot McKnight, "Cain," Dictionary of the Old Testament Pentateuch, ed. T. Desmond Alexander and David W. Baker (Downers Grove, IL: InterVarsity Press, 2003), 108. 
that it is the "different approach to worship that counted and that this was reflected in the quality of their gifts." ${ }^{26}$ Biblical history shows that God rejects syncretism, in which worshipers draw near to God and to other gods simultaneously.

The human heart does not operate in a vacuum or in neutrality. Cornelius Van Til was right to argue that "the idea of 'neutrality' is simply a colorless suit that covers a negative attitude toward God. It ought to be plain that who is not for the God of Christianity is against Him." ${ }^{27}$ This stands against the claim of theological pluralism that all human ways are acceptable to God. Jesus clearly taught, "For where your treasure is, there your heart will be also" (Matt 6:21 Esv). The hearts of Abel and Cain were directed to different objects, though they had come for worship into the presence of the same God. To be in the presence of God does not necessarily mean to worship him, as the human heart's desires are subtle. God accepts worship when it is truly and properly submissive to him. It was according to this principle that God condemned Israel's worship: "And the Lord said: 'Because this people draw near with their mouth and honor me with their lips, while their hearts are far from me, and their fear of me is a commandment taught by men ..." (Isa 29:13 ESv; cf. Matt 15:8-9; Mark 7:6).

Explaining God's differentiation between Cain and Abel, John Calvin argues, "God will regard no works with favor except those the doer of which is already previously accepted and approved by him." ${ }^{28}$ This favor comes through God's initiative of regenerating human hearts to worship him by faith. Calvin highlights in God's words to Cain the need "to worship God sincerely and without dissimulation" and in "true purity of heart." ${ }^{29}$ These were lacking in Cain's case, and warranted rejection. Furthermore, "God not only repels his unjust complaint, but shows that Cain could have no greater adversary than that sin of his which he inwardly cherished." ${ }^{30}$

Pre-Christ worship was permeated with human errors and consequently rejected by God. Even when God prescribed acceptable worship in the Old Testament, it was constantly diverted by sin and degenerated into idolatry. The core of religious life that God demanded was to walk in "obedience to him, to love him, to serve the LoRD your God with all your heart and with all your soul" (Deut 10:12 NIV). The goal of this demand was that obedience

${ }^{26}$ Gordon J. Wenham, Genesis 1-15, WBC 1 (Waco, TX:Word, 1987), 104.

${ }^{27}$ Cornelius Van Til, A Survey of Christian Epistemology (Phillipsburg, NJ: Presbyterian and Reformed, 1969), 7-8.

${ }^{28}$ John Calvin, Commentary on Genesis (Albany, OR: Ages Digital Library, 1998), 120.

${ }^{29}$ Ibid., 125.

${ }^{30}$ Mohler, "Do Christians and Muslims Worship the Same God?" 
would be the channel through which God's love and blessings would flow in the land for the good of all. When later generations deviated from this demand, Micah reiterated it, using practical terms such as acting justly, loving mercy, and walking humbly with God (Mic 6:8). Humility is vital, since the qualities of justice and mercy only flourish where religion is structured on humility. Pride destroys the soil in which virtues thrive. Free mercy from God implies absence of merit and requires absolute humility in fellowship with him and other people. Absence of humility in religious practice nurtures discrimination and violence, even in the name of God. God is fully aware of the human heart, for which reason he instructed that we walk humbly with him. These qualities are relational categories that make human society blossom according to God's original intention for it. Israel could not practice this because under the law human depravity and sinful arrogance was exposed. In addition to spiritual decadence, it bred social injustice, which the prophets decried.

The religion of the law alone fashioned stony hearts and lip service, whereas the gospel promises hearts of flesh held obedient to the word of God. The entire Old Testament therefore looked to the coming of Christ, when worship that is acceptable to God would be instituted. Christ made very clear, as no one else before him, that he is the way to the Father, through which proper worship of God can be in spirit and in truth.

Christianity's claim that Christ is the center of worship makes it impossible to admit Judaism and Islam as worshiping the same God. Christ made the love of God and fellow humans the cardinal principle of the Christian religion, thus summing up Micah's call to religious practices of justice, mercy, and humility in human society. Where these three qualities reign, religious violence is impossible. This means submission of hearts to the rule of God so that true worship is no longer anchored on legalistic rituals but true, heart-level communion with the Lord. The Holy Spirit, who agrees with the person and work of Christ, effectually transforms hearts; religion is a religion of heart and deed. Any worship of God outside of Christ and the Holy Spirit is futile, no matter how well organized and pious it might appear. Eternal life consists in the knowledge of God through Christ alone (John 17:3).

Christ not only denied that the Samaritans and Jews worshiped the same God (John 4:22), he called the Jews children whose father was Satan (John 8:44) because, though they believed in one God, they rejected him as God's Son, who together with the Father would send the Holy Spirit. From this, it follows that true worship is Trinitarian. Jews and Muslims cannot strictly be said to worship the same God, inasmuch as they disagree with the 
essential particulars of his revelation of himself in the Bible. Belief in some of the basic aspects of deity does not necessarily amount to worship of that deity. In many religious societies, though people believe in a number of gods, they also hold some basic beliefs about the one eternal God as found in Christianity, Judaism, and Islam. For instance, African traditional religions believe in one supreme deity who is the creator of the universe and who is almighty, hears prayers, and saves people. Yet they cannot be said to be worshiping the God of Christianity. To flatten the significant distinctions undermines the gospel call to repentance, including to Muslims and Jews.

It is possible to concede that Christians and Muslims worship the same God if this refers to the general concept of one supreme deity, the creator of the universe, the almighty and supreme judge of mankind. However, in the Qur'an the personal attributes of God in Christianity are heretical. According to Qur'an 5:73, “They do blaspheme who say: Allah is one of three in a Trinity: for there is no god except One Allah. If they desist not from their word (of blasphemy), verily a grievous penalty will befall the blasphemers among them." ${ }^{31}$ But to some extent, the Qur'an still admonishes Muslims with respect to Christians and Jews: "Our God and your God is One, and unto Him we surrender" (29:46). ${ }^{32}$

The fundamental differences between the two religions are logically irreconcilable. It is impossible for God to be God without Trinity, and those who believe in him as unity without Trinity cannot worship the same God. Whatever overlap there is between the Christian and Muslim beliefs about God is superficial: "What God has done or whom He has sent is far less of a defining characteristic than what $\mathrm{He}$ is and who $\mathrm{He}$ is; though Islam and Christianity overlap at points on the former, they differ fundamentally on the latter." ${ }^{33}$ Qur'an 3:85 says, "And whoever seeks a religion other than Islam, it will never be accepted of him, and in the Hereafter he will be one of the losers." ${ }^{34}$

\section{A Classic Reformed Approach}

Reformed scholarship holds that general revelation, especially the concept of sensus divinitatis, warrants overall human belief in the existence of one

\footnotetext{
${ }^{31}$ Yusuf Ali, citing Sura 5:73. Cited at "Islam and the Trinity," Department of Christian Defense, http://www.christiandefense.org/isalm_Trinity.htm.

${ }^{32}$ Qureshi, "Do Muslims and Christians Worship the Same God?” Citing the Qur'an.

${ }^{33}$ Ibid.

${ }^{34}$ David R. Reagan, "Do Christians, Muslims and Jews Worship the same God?," Lamb \& Lion Ministries, http://christinprophecy.org/articles/do-christians-muslims-and-jews-worshipthe-same-god/.
} 
Creator God. ${ }^{35}$ The connection between worship, belief, and reference grants that ultimately all religions, irrespective of whether they are true or false, have God in view. ${ }^{36}$ With reference to the basic descriptive categories of creatorhood, omnipotence, omniscience, and omnipresence, the three Abrahamic religions refer to the same God, but the Reformed view goes beyond basics to personal ontological categories for God, and so Christianity differs significantly from the other two. ${ }^{37}$ Special revelation introduces categories that are alien to Judaism and Islam. However, it is possible that the three Abrahamic religions refer to the same God in spite of "their considerable differences of opinion about his exact properties." 38

Though the above view presents good and cogent arguments, it also opens itself to certain misunderstandings. For instance, it claims that "insofar as other religions have also arisen from genuine cognitive contact with God that isn't distorted by fundamentally mistaken beliefs about what kind of being $\mathrm{He}$ is, they too refer to the same God." ${ }^{39}$ These questions follow: What are those religions, given that religions such as Hinduism do not conceive of God in the way Christianity, Judaism, and Islam do? Such blanket assertions are not helpful in establishing a case. Can such genuineness be measured, and does "genuine cognitive contact with God that isn't distorted" square up with the noetic effect of sin that Paul speaks of in Romans 1:21-23? When God disowned his own people in the prophetic writings, was it not because of what amounts to a distortion of their theistic cognitive content?

However, on a positive note, this view holds that "belief in God requires more than mere reference, so the fact that the Reformed view can be taken to imply that users of 'God' in these religions all refer to the same God doesn't automatically mean that Jews, Christians and Muslims all believe in the same God." ${ }^{40}$ And more forcefully,

The conclusion we draw from this is that the question whether Jews, Christians, and Muslims believe in and worship the same God doesn't allow for a firm univocal answer. On the one hand, since belief in the same God requires commitment to the same characterization of God's basic nature, they do not believe in the same God and hence do not worship the same God. ${ }^{41}$

\footnotetext{
35 Jeroen de Ridder and René van Woudenberg, "Referring to, Believing in, and Worshipping the Same God: A Reformed View," Faith and Philosophy 31.1 (2014): 50.

${ }^{36}$ Ibid., 59.

${ }^{37}$ Ibid., 60.

${ }^{38}$ Ibid., 64.

${ }^{39}$ Ibid., emphasis mine.

${ }^{40}$ Ibid., 65.

${ }^{41}$ Ibid., 66.
} 
In the final analysis, "It follows from the Reformed view that, strictly speaking, adherents of the Abrahamic religions do not believe in and worship the same God." ${ }^{42}$

The irreconcilable differences between Christianity, Judaism, and Islam concern the critical issues of revelation, sin, and redemption. Harold Spencer writes, "In the light of God's character we understand the nature of sin and our need for the salvation which Christ brings." ${ }^{33}$ God reveals himself and the human condition, explaining the difference between original creation and the state after the fall, and the need of salvation. The natural person blinded by sin and ignorant pride does not and cannot understand his own actions. Even the Apostle Paul still did not understand his own actions even after having received Christ (Rom 7:15).

Calvin offered a classic approach to this difference with the uniquely Christian idea that Creator and Redeemer are two aspects of the revelation of the one God, teaching that "in the fashioning of the universe as in the general teaching of Scripture the Lord shows himself to be simply the Creator." ${ }^{44}$ General revelation is a religious cognitive point of common ground for all religions. Commenting on Psalm 19, Calvin admits the common knowledge of God: "It is very evident that the inspired poet here treats of the knowledge of God, which is naturally presented to all men in this world as in a mirror." ${ }^{45}$ This first step of the revelation of God is primary and open to humanity in all religions. But the second aspect of God's revelation takes a unique stance that is extraordinary. This was necessitated by the distortion of mankind's clear vision of God and the impaired relationship between the creature and its Creator.

On account of sin, mankind not only rebelled initially but continued in its covenant-breaking attitude and character. Paul says that "what can be known about God is plain to them, because God has shown it to them," but "although they knew God, they did not honor him as God or give thanks to him, but they became futile in their thinking, and their foolish hearts were darkened" (Rom 1:19, $21 \mathrm{ESV}$ ). It is this striking reality of the human condition that made it necessary for the revelation of God as Redeemer. Calvin comments,

42 Ibid.

${ }^{43}$ Harold Spencer, Islam and the Gospel of God (New Delhi: Printsman, 1976), 1.

44 John Calvin, Institutes of the Christian Religion, ed. John T. McNeill, trans. Ford L. Battles (Louisville: Westminster John Knox, 1960), 1.2.1 (1:40).

45 John Calvin, Commentary on the Psalms (Albany: Ages Digital Library, 1998), 1:304. 
For as God, the Creator of the world, pours forth upon us the brightness of the sun, and gives us eyes to receive it, so, as the Redeemer, in the person of his Son, $\mathrm{He}$ shines forth, indeed, upon us by His gospel, but, as we are blind, that would be in vain, if $\mathrm{He}$ did not at the same time enlighten our understandings by His Spirit. His meaning, therefore, is that God has, by His Spirit, opened the eyes of our understandings, so as to make them capable of receiving the light of the gospel. ${ }^{46}$

The Pelagians generated controversy with the claim that "everyone well grounded in whatsoever religion will be saved." ${ }^{47}$ However, the starting point in discussing the uniqueness of God in Christian theology is the sin factor, which necessitated the special revelation of God that climaxes in the incarnation. While Christianity, and indeed Reformed theology, underscores the magnitude of $\sin$, "Islam denies that humans have a deeply sinful human nature, claiming that we sin because we are merely weak and ignorant." ${ }^{48}$ This means that humanity is not actually in need of salvation from God but can earn it only by overcoming weakness and ignorance.

Calvin laid the foundation for the classic Reformed view that the three Abrahamic religions are not praying to, serving, and worshiping the same God. God as Redeemer is closer to humanity in a personal way. Calvin took seriously human incapability to meet the holy requirements of God and escape the consequences of the fall. God's initiative is to come down to fallen humanity in his chosen way, and fallen humanity ought to seek redemption only in Christ. ${ }^{49}$

Calvin did not underestimate the grave consequences of the fall, especially as it affects our natural ability to know and worship God. There must be a way acceptable to God, since he is not careless in his ways. "Therefore, since we have fallen from life into death, the whole knowledge of God the Creator that we have discussed would be useless unless faith also followed, setting forth for us God our Father in Christ." ${ }^{50}$ On this note, "no worship has ever pleased God except that which looked to Christ." William Barr states that in religious and theological enterprise, "thinking and speaking of

${ }^{46}$ Ibid. See also John Calvin, Commentary on the Second Epistle to the Corinthians (Albany: Ages Digital Library, 1998), 92.

${ }^{47}$ Francis Turretin, Institutes of Elenctic Theology, vol. 1, trans. George Musgrave Giger, ed. James T. Dennison, Jr. (Phillipsburg, NJ: P\&R Publishing, 1992), 1.4.1 (p. 9).

${ }^{48}$ Douglas Groothuis, "Do Christians and Muslims Worship the Same God?" (citing Harold Netland, Dissonant Voices: Religious Pluralism and the Question of Truth [Vancouver, BC: Regent University Press, 1977], 89-90), Denver Seminary, http://www.denverseminary.edu/ do-christians-and-muslims-worship-the-same-god/.

${ }^{49}$ Calvin, Institutes 2.6.1.

${ }^{50}$ Calvin, Institutes 2.6.1 (1:341).

${ }^{51}$ Calvin, Institutes 2.6.1 (1:342). 
God must be done in the midst of and in relation to a world in which there is massive suffering and terrible acts of cruelty." ${ }^{2}$ The God who reveals himself as Redeemer considers the human predicament destructive enough to deliver us from it.

Calvin's theology did not credit the three Abrahamic religions, including Roman Catholicism, with worship of the same God, even if the referent may be the same. In his sermons, he consigns Catholicism, Judaism, and Islam to the realm of false religions which stand against the things of God.

Although the Heathen keep still their dotages; although the Jews [alias the Judaists] be wilful in maintaining these false expositions of the law; although the Turks hold still their Mahomet's Al-Coran; although the Papists be still entangled in their superstitions-all is one! For they [all of them maintain or] hold fast this principle, that there is a God. ... Meantime, they ... worship a puppet, and ... have transformed the Majesty of God [viz. the one and only true Triune God] - though their intent was to worship the living God. ... The Papists do, who protest that they worship God the Maker of heaven and earth. And likewise the Turks, who say the same thing. And so also do the Jews [alias the Judaists] — notwithstanding that they abhor Jesus Christ. ${ }^{53}$

Calvin's reaction against the Turks, or Muslims, was based on the distortion of Christian theology in their beliefs, which leads to violent actions.

Calvin reasoned that God in his infinite majesty is unapproachable other than through the incarnation of his Son as mediator. To reject the Son and yet claim to have a personal relationship with God and to worship him truly is false: "For even if many men once boasted that they worshiped the Supreme Majesty, the Maker of heaven and earth, yet because they had no Mediator it was not possible for them truly to taste God's mercy, and thus be persuaded that he was their Father." ${ }^{54}$ This view places Judaism and Islam together: by not accepting Christ, both possess "a fleeting knowledge of God." 55 On Muslims, Calvin states, "So today the Turks, although they proclaim at the top of their lungs that the Creator of heaven and earth is God, still, while repudiating Christ, substitute an idol in place of the true God." ${ }^{\prime 6}$ Equally, when Judaism took the sacrificial system to be a means of getting right with God, it missed the point of the law. Calvin insisted that the prophets indicted Judaism because "the law was not devoid of reference

\footnotetext{
52 William R. Barr, ed., Constructive Christian Theology in the Worldwide Church (Grand Rapids: Eerdmans, 1997), 107.

${ }^{53}$ Francis Nigel Lee, Calvin on Islam (El Paso, TX: Lamp Trimmers, 2000), 4.

${ }^{54}$ Calvin, Institutes 2.6.4 (1:347).

55 Calvin, Institutes 2.6.4 (1:348).

${ }^{56}$ Ibid.
} 
to Christ." ${ }^{57} \mathrm{He}$ even considered that "the two horns of the Anti-Christ and the two legs correspond with Islam and the Papacy." 58

Francis Turretin wrestled with Socinians and Remonstrants, who denied that "no one can be saved who is not placed in Christ by true faith," and affirmed that sin warranted redemption in Christ alone. ${ }^{59}$ Arminius argued that for anyone who makes "right use of the light of nature, the light of grace can be obtained, and by grace admission to glory." " Although Turretin stated that "certain first principles of religion are common to all men," the more important question for him is whether such principles sufficiently constitute true religion, which he denies ${ }^{61} \mathrm{He}$ asserts instead that "since the Scriptures testify that Christ is the only way of salvation (without whom no one can come to the Father), it is criminal to suppose an extraordinary way without him." ${ }^{62} \mathrm{He}$ maintained the position of Calvinism: "It is one thing to allow some knowledge of God as Creator and preserver however imperfect, corrupt and obscure; another to have full, entire and clear knowledge of God as Redeemer and of the lawful worship due to him.." ${ }^{33}$ The knowledge of God as Creator of the universe is sufficient to leave all without excuse for not believing, but this does not impart salvation, which is revealed in Christ alone, who is the express will and mercy of God for humanity.

Reformation theology stood on the biblical premise that God created the world, and that mankind was endowed with the capacity to relate with him, and even before the fall, human fellowship with God was regulated by God, not humanity. God told Adam everything that he needed to do for the well-being of the creation. However, sin has infected humanity to the extent that "what the world judges right is often crooked and perverse in the judgment of God, who approves of no other manner of living, than that which is framed according to the rule of his law." ${ }^{44}$ Divine light became necessary for people to walk uprightly with God. Thus the Psalmist acknowledges, "Your word is a lamp to my feet and a light to my path" (Ps 119:105). The metaphors of "feet" and "path" here allude to human conduct in relationship with

\footnotetext{
${ }^{57}$ Calvin, Institutes 2.7 .1 (1:349).

${ }^{58}$ John Calvin, Sermons on Deuteronomy (Edinburgh: Banner of Truth Trust, 1987), 162.

59 Turretin, Institutes, 1.4.1 (1:9); citing Socinus, Praelectiones theologica 2 (1627), 3-7; Curcellaeus and Adolphus Venator (Adolph de Jager) were defending their beliefs against the ministers of Dort.

${ }^{60}$ Turretin, Institutes, 1.4 .1 (1:9-10). Turretin refers to Arminius, "The Apology or Defence of James Arminius Against Certain Theological Articles," 15-17, in The Writings of James Arminius [1956], 1:322-29.

${ }^{61}$ Turretin, Institutes, $1.4 .3(1: 10)$.

${ }^{62}$ Turretin, Institutes, $1.4 .5(1: 10)$.

${ }^{63}$ Turretin, Institutes, 1.4 .6 (1:11).

${ }^{64}$ Calvin, Commentary on the Psalms, 1:568.
} 
God and humanity. So the word of God is "a guide in leading a holy life."65 God came to redeem his creation from sin and its effects, the most prominent of which is death. And the only person who defeated death is Jesus Christ, the Son of God. No other prophet, in Judaism, Islam or another religion, was able to defeat death for mankind. This is God's chosen way to deal with the human condition, and Jesus is the final authentic eschatological spoken word of God (Heb 1:1-3).

Herman Bavinck added a third dimension to that of Calvin, making it Trinitarian. He emphasized the centrality of the Trinitarian God who is manifest as "Creator, Redeemer and Perfecter." 66 Bavinck succinctly presented the unique position of Christian faith: "And the essence of the Christian religion consists in the reality that the creation of the Father, ruined by $\sin$, is restored in the death of the Son of God and re-created by the grace of the Holy Spirit into a kingdom of God." ${ }^{67}$ Bavinck underscored a critical factor, namely, sin, which forms the basis for appreciating the special redemptive revelation of God, not only as Creator but also as Redeemer. God created the world for the good of mankind, but sin ruined it. Sin is an offense to a personal, holy God. Any god who does not take the offense of sin seriously cannot be a personal and holy God. The gravity of sin and its consequences cannot be remedied by mankind, which has lost the power to please God. Mankind is a victim of sin, and the remedy for sin can only be provided by God. Only God, who created mankind in his own image, can re-create mankind for his purpose.

\section{Conclusion}

Belief that Christians, Jews, and Muslims worship the same God cannot be established. The variance between the three is critical, especially the uniquely Christian idea that Christ is the sine qua non of true worship of God. While proponents of the idea that all worship the same God cite the Qur'an's recognition of Jews and Christians as people of the book and the words of Nicholas of Cusa or Pope Gregory VII, they have not shown similar evidence from the Bible. The Old and New Testaments know nothing of these claims. Although the Old Testament looks to the New Testament,

\footnotetext{
${ }^{65}$ Ibid.

${ }^{66}$ Herman Bavinck, Reformed Dogmatics, vol. 1, Prolegomena, ed. John Bolt, trans. John Vriend (Grand Rapids: Baker Academic, 2003), 112. He drew from Bonaventure's articulation.

${ }^{67}$ Ibid. See also John Bolt, "Editor's Introduction," citing Bavinck in Reformed Dogmatics, vol. 2, God and Creation, ed. John Bolt, trans. John Vriend (Grand Rapids: Baker Academic, 2004), 18.
} 
since the time of Jesus and the apostles Judaism has never recognized such a fulfillment. Naturally, Judaism and Christianity, its offshoot, should have common worship, but their theological trajectories are at variance as to the core tenets of faith, the Trinity and the Messianic redemption of Christ. Though Judaism and Islam sprang from the Abrahamic family and faith, Muhammad laid the foundation of Islamic variance from Judaism. The Jewish rejection of Muhammad as prophet heightened the tension, and the divergence has widened.

Classic Reformed theology has sufficiently demonstrated why worship differs. The revelation of the Creator God to all mankind has been blurred by $\sin$, and God alone has taken the initiative to reveal himself again as Redeemer of fallen creation. Islamic theology fails to take sin seriously and misinterprets the redemptive activity of God in the person of Christ, who died and rose again for the sake of mankind. This redemption is operative until the consummation of time, when all things will be perfectly renewed. This is the work of God the Father, God the Son, and God the Holy Spirit, three persons, but one God. This makes the Christian religion unique, and it cannot be compromised for the sake of peaceful coexistence. The hope of common ground with Islam has never and probably will never result in the peaceful coexistence its proponents expect. While we encourage humility in our interactions with adherents of other religions, we hold our central principle of worship to be true and unique. 



\title{
Transhumanism: Anthropological Challenge of the Twenty-First Century
}

\section{YANNICK IMBERT}

\begin{abstract}
Transhumanism is a philosophical and cultural movement that promotes human enhancement through advanced technological means such as nanotechnology. The philosophical characteristics of transhumanism, including the belief that human beings are modifiable at will, make it one of the most important anthropological challenges of the twenty-first century. This article introduces the main elements of transhumanism and highlights some possible apologetical interactions.
\end{abstract}

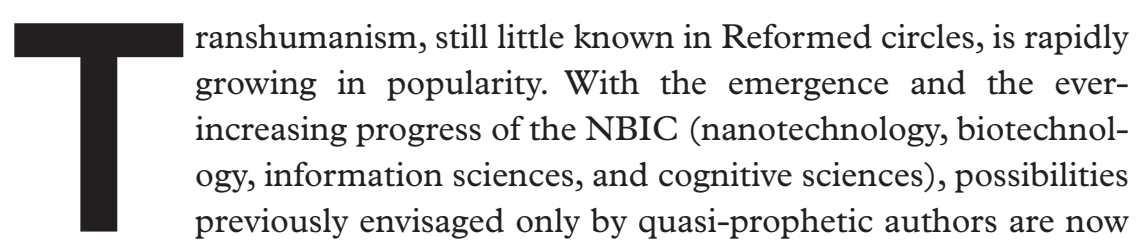
at hand. This movement, which does not accept human limits (such as illness, death, etc.), seeks to transcend those boundaries. If transhumanism is not the fiction some might imagine, it is necessary to present the main features of its history in order to understand it.

This article was first published in French in Théologie Évangélique 14.2 (2015): 29-50, and translated by the author and published with the permission of Théologie Évangélique. 


\section{Short History of Transhumanism}

Before considering the nature of transhumanism, let us look briefly at its history. To do so, it is necessary to go back to the 1950s and 1960s in the United States. Although transhumanism only gained a public voice during the 1980s and 1990s, its current form emerged around twenty years before. Indeed, pre-transhumanist intuitions had already emerged in the late 1920s and 1930s, but these philosophical intuitions remained without immediate consequences mainly because of the Second World War. Through investigating this "archeological" point we meet one of the fathers of transhumanism. The ancestry of this movement dates back to the first use of the term by Julian Huxley, brother of Aldous Huxley, who wrote in 1927, ${ }^{1}$

We shall start from new premises.... The human species can, if it wishes, transcend itself-not just sporadically, an individual here in one way, an individual there in another way, but in its entirety, as humanity. We need a name for this new belief. Perhaps transhumanism will serve: man remaining man, but transcending himself, by realizing new possibilities of and for his human nature. "I believe in transhumanism": once there are enough people who can truly say that, the human species will be on the threshold of a new kind of existence, as different from ours as ours is from that of Pekin man. It will at last be consciously fulfilling its real destiny. ${ }^{2}$

In the years 1960-1970, the development of transhumanist thought followed closely the cultural wave of American science fiction represented by authors such as Arthur C. Clarke, Isaac Asimov, Robert Heinlein, and Philip K. Dick. This explains why today transhumanism remains a cultural movement too frequently associated with the science fiction genre. It would then be the pursuit of dreaming scientists, professors of robotics or science fiction geeks-nothing really serious. This is a simplistic and rather naive perspective on transhumanism. We must remember that science fiction itself has contributed to the development of robotics-for example, science fiction even gave us the word robot. ${ }^{3}$

1 The invention of the term "transhumanism" is dated by Nick Bostrom to 1927 with the publication of Julian Huxley's Religion Without Revelation. Nick Bostrom, "A History of Transhumanist Thought," fournal of Evolution and Technology 14.1 (April 2005), online, http://www.nickbostrom.com. However, the term does not appear in this book, although the concept is already present, as in the following note: "[Man] is not only constantly overcoming what he thought were the limits of his nature, but in an individual and social development, also in the process of transcending its own nature, emerging into a new accomplishment." Julian Huxley, Religion Without Revelation (London: Benn, 1927), 356.

2 Julian Huxley, "Transhumanism," in New Bottles for New Wine (London: Chatto \& Windus, 1957), 17.

3 The Czech writer Karel Čapek invented the neologism "robot" in his play Rossumovi Univerzálni Roboti (R.U.R., Rossum's Universal Robots), published in 1920. However, the 
In these same years, 1960-1970, began to emerge one of the underlying philosophical foundations of transhumanism. Reinterpreted in a context of sociopolitical protest and nurtured by technological advances that opened new horizons, the "French theory" quickly became the anchor of a variety of movements such as deconstructionism, gender studies, and of course transhumanism. ${ }^{4}$ With the radical deconstruction of the subject and objectivity, philosophical opportunities to "remake the human" were perceptible. ${ }^{5}$ The only remaining step for transhumanism was to make further technological progress in the fields of artificial intelligence and nanotechnology. The years 1980-2000 saw the accomplishment of precisely that.

In the early 1960s Fereidoun M. Esfandiary, a pioneer of transhumanism, symbolically changed his name to FM-2030. This change was an expression of his hope that, by the time of his hundredth birthday in 2030, humanity would have reached technological immortality. Building on this conviction, he formed one of the first groups of "futuristic" minded people. If he was one of the first great figures of transhumanism, he is far from being the only or even the most prominent. In 1965 appeared a name that became a symbol of transhumanism: Ray Kurzweil, one the most prominent inventors and thinkers of transhumanism, who received numerous awards for his technological advances as well as two major books, The Age of Spiritual Machines (2000) and The Singularity Is Near (2006).

In The Age of Spiritual Machines, Kurzweil made technological predictions, some of which were complete failures and contributed somewhat to discrediting him. For example, he predicted that by 2009 a $\$ 1,000$ computer would be able to make a trillion calculations per second, but the fastest of our regular computers make barely ten billion. Further, computer-controlled cars are far from being widespread, even on highways-although some steps in this direction have already been made. On the other hand, most of our electronic gadgets can actually connect wirelessly, and laptops are the size of a small book, and may soon be that of a credit card ${ }^{6}$ Despite a rather

term robotics and some more fundamental intuitions go back to Isaac Asimov, undoubtedly one of the most influential authors of science fiction in the twentieth century. Science fiction is certainly one of the three major influences that Gilbert Hottois sees in the origin of transhumanism. See Gilbert Hottois, "Le transhumanisme entre humanisme et posthumanisme," Foi et vie 114.4 (December 2014): 27-45, here 38.

4 The precise relationship and mutual influence between these different currents are complex, particularly because of the impossibility of systematizing transhumanism.

5 Strangely, this influence is not mentioned among the "origins" of transhumanism in the special issue of Foi et vie. See Vincens Hubac, "Science sans conscience: Le transhumanisme est-il un humanisme?," Foi et vie 114.4 (December 2014): 9-26.

${ }^{6}$ For a list of futuristic predictions by Raymond Kurzweil, see especially chapters 9-11 of his The Age of Spiritual Machines (New York: Penguin, 1999), 189-233. The number of Kurzweil's predictions, and the myth that resulted, even earned them their own Wikipedia page! 
impressive list of technological "prophecies," Kurzweil gave the impression of being an inventor out of touch with reality. Of course, it should not be forgotten that in 1999 he received the National Medal of Technology and Innovation, the highest technological award in the United States, and two years later, in 2001, the Lemelson-MIT Prize, the highest international distinction in the field of technological innovation. ${ }^{7}$ Kurzweil is also one of the technological gurus of the Google empire.

An upturn in the history of the movement happened in 1982 during a meeting of the American Association for Artificial Intelligence. Vernor Vinge used for the first time a term that quickly became one of the keywords of transhumanist philosophy: the Singularity. Under Vinge's pen, the term embodies the slogan that "within thirty years, we will have the technological means to create superhuman intelligence. Shortly after, the human era will be ended." A few years later, in 1988, the first issue of Extropy magazine was published by philosophers Max More and Tom Morrow. ${ }^{9}$ Then, in 1991-1992, they founded the Extropy Institute, ${ }^{10}$ an organization dedicated to the promotion of extropianism, a philosophy defined as "an inspiring and uplifting view of life while remaining open to revision according to science, reason, and the boundless search for improvement." ${ }^{11}$ This view is unsurprisingly based on "challenging human limits by means of science and technology combined with critical and creative thinking." ${ }^{\prime 2}$ As such, extropianism can be seen as uninhibited scientism, breaking the shackles of philosophical contradictions and ethical boundaries. But the importance of this institute lay beyond its philosophical assertions: its imposing mailing list defines one of the first public manifestations of transhumanism, a movement still in the process of structuring itself.

\footnotetext{
7 "Raymond Kurzweil," Massachusetts Institute of Technology, http://lemelson.mit.edu/ resources/raymond-kurzweil.

8 Vernon Vinge, "What Is the Singularity?," Mindstalk, 1993, http://mindstalk.net/vinge/ vinge-sing.html.

9 These two authors also symbolically changed their names as did FM-2030. The first changed his name from Max T. O'Connor to Max "More" and the second, Tom Bell, to Tom Morrow (also sometimes referred to as T. O. Morrow, "tomorrow").

${ }^{10}$ Contrary to what is sometimes written, this institute is not the first transhumanist association to have been created - the Foresight Institute was founded in 1986. Contra Thibault Dubarry and Jérémy Hornung, "Qui sont les transhumanistes?," Sens Public, June 17, 2011, http://www.sens-public.org/article527.html?lang=fr.

${ }^{11}$ MaxMore, "Extropian Principles," High Existence, http://highexistence.com/the-extropianprinciples/. The term "extropy" was coined as a metaphorical opposite of entropy, thus indicating a belief in unlimited progress of human beings by means of scientific and technological improvement.

${ }^{12}$ Ibid.
} 
While the Extropy Institute was organizing its first transhumanist conferences, the need for a more systematic organization of the movement became obvious, and a few years later, in 1998, the World Transhumanist Association was founded by Nick Bostrom and David Pearce. This association was to provide the organizational structure for transhumanist interest groups and to open the doors of political influence. If the WTA does not speak for all transhumanist subgroups, it does represent enough to be legitimately regarded as one of its leading voices. ${ }^{13}$ Two major documents of the WTA, the "Transhumanist Declaration" and its "FAQ" are among the best-known transhumanist writings. ${ }^{14}$

At the same time, another major transhumanist, Hans Moravec, adjunct professor at Carnegie Mellon University, published several works and led major scientific research in the field of robotics and artificial intelligence. In 1989 he published Mind Children, exploring the possible implications of robotics and mind (or consciousness) uploading. His particular emphasis on the transition towards artificial intelligence is reminiscent of some intuitions of Isaac Asimov in his "Robot" series, or of certain expectations of cyberpunk author William Gibson-notably in his Neuromancer, published in English in 1984..$^{15}$

Since 2000-2005, the transhumanist movement has continued to grow and diversify. The current network is composite and nonuniform, gathering figures as diverse as Ray Kurzweil, Nick Bostrom, Natasha Vita-More (a leading transhumanist artist), Max More, and Aubrey de Grey, a specialist in the fight against aging. ${ }^{16}$ At the beginning of the twenty-first century,

13 That said, James Hughes has shown that the WTA represents a particular branch of transhumanism he labels "democratic-liberal transhumanism" as distinguished from "libertarian transhumanism" (represented by Max More and the Extropy Institute) or "fascist (or eugenic) transhumanism" or even "radical democratic transhumanism." See James J. Hughes, "The Politics of Transhumanism," F. Hughes' Projects, March 2002, http://www.changesurfer.com/ Acad/TranshumPolitics.htm. Note that the World Transhumanist Association has morphed into Humanity+.

${ }^{14}$ The Transhumanist Declaration is available online on the Humanity+ website, World Transhumanist Association, http://humanityplus.org/philosophy/transhumanist-declaration/. The statement is also published in Max More and Natasha Vita-More, eds., The Transhumanist Reader (Oxford: Wiley-Blackwell, 2013): 54-55.

${ }^{15}$ William Gibson, Neuromancer (New York: Ace, 1984). This particular work is often considered the founding work of cyberpunk, a subgenre of science fiction often dealing with the social implications of technological transformation. Cyberpunk often positions itself in a nihilistic worldview and deals with the consequences of enhancements on human nature. Writers and filmmakers within this subgenre include William Gibson, Neal Stephenson, and in a certain way, Philip K. Dick. Other media include a significant cyberpunk influence, including movies (Bladerunner, Robocop, Strange Days) and anime (Ghost in the Shell, Akira, Psycho-Pass).

16 The end of aging, often considered one of the essential elements of transhumanism, is, for example, not affirmed by all the thinkers associated with the movement, unlike the promotion 
transhumanist lobbies in the political and economic fields grew. Several indicators testify to the vision of the movement: the birth of a transhumanist party, founded by the writer Zoltan Istvan; the support of major figures like Larry Page (Google cofounder), Bill Gates (founder of Microsoft), Martine Rothblatt (United Therapeutics, Sirius), and Peter Thiel (founder of PayPal and Facebook administrator); and the synergy between the transhumanist innovation and some public institutions such as the US space agency, NASA, which houses the Singularity University of California.

The transhumanist movement, not surprisingly, is less represented in France. Not until 2010 was the first transhumanist association, Technoprog, created. Its first years were low in activity, as it was mainly building up the national network and organizing a few conferences. Technoprog organized its first international conference on transhumanism, Transvision, in November 2014, which was also funded by Humanity+. Among the authors and networks that attracted the attention of a growing readership were the think tank NeoHumanitas ${ }^{17}$ and Gérard Chazal, author of Philosophie de la machine (Philosophy of the Machine) and a growing number of respectable online resources-such as the article on transhumanism in the Encyclopaedia Britannica. Transhumanism is also the subject of interaction with religions, as in the case of French sociologist Raphaël Liogier, who edited a volume on transhumanism and contributed to an article from the Buddhist perspective. ${ }^{18}$

\section{Attempt at Definition}

Defining transhumanism is difficult. Because of the lack of uniformity of thought and major academic works, definition is forced back to broad key definitions or features mentioned by transhumanism itself. Moreover, while "one" transhumanism is referred to, the movement cannot be defined as a uniform reality, and its nuances should be noted. Further, it suffers from a deficient public image, often being seen as an idealist and Promethean movement. As a result, it is often considered ambiguously or negatively. However,

whether hazardous manipulators of the living, unscrupulous entrepreneurs, new utopians, realistic lobbyists or harmless dreamers, transhumanists raise a simple

of longevity. Aubrey de Grey is one of the main promoters of the fight against aging. See Aubrey de Grey, Ending Aging:The Rejuvenation Breakthroughs That Could Reverse Human Aging in Our Lifetime (New York: St. Martin's Griffin, 2007).

${ }^{17}$ NeoHumanitas, http://www.neohumanitas.org.

${ }^{18}$ Raphaël Liogier, ed., De l'humain: Nature et artifices, La pensée de midi 30 (Arles: Actes Sud, 2010). 
question: what is happening to human beings in the early twenty-first century, when it seems we have acquired an unprecedented capacity to influence our biological nature? ${ }^{19}$

This is an implicit reference to what became one of the defining features of transhumanism, that is, its support for emerging technologies, in particular for the NBIC. A brief provisional definition of transhumanism is found in the opening of the Transhumanist Declaration:

Humanity will be radically changed by technology in the future. We foresee the feasibility of redesigning the human condition, including such parameters as the inevitability of ageing, limitation on human and artificial intellects, unchosen psychology and physiology, suffering, and our confinement to the planet earth. ${ }^{20}$

According to transhumanism, these technologies could affect the various dimensions of human life such as physiology, rejuvenation, intelligence, emotion regulation, and the abolition of suffering. For Max More, the use of the NBIC explains the essential difference between "humanism" and "transhumanism":

Transhumanism differs from humanism in its recognition and anticipation of radical changes present in nature, and in human possibilities resulting from various sciences and technologies such as neuroscience and neuropharmacology, life extension, nanotechnology, artificial ultra-intelligence, combined with a philosophy and a system of rational values. ${ }^{21}$

Devoted rationalism, assumed scientism, and self-proclaimed Prometheanism: those are, at first reading, the main features of transhumanism. An article on the Metanexus website presents another relevant definition of transhumanism as "a rather simple idea: within certain limits that require investigation, it is desirable to use emerging technologies to enhance human physical and cognitive capacities, and to make other beneficial alterations to human traits."22

${ }^{19}$ Gabriel Dorthe, "Naissance permanente ou immortalité? Essai de cadrage du transhumanisme," Studia philosophica 70 (2011): 35-43.

20 "Transhumanist Declaration," $\ 1$.

${ }^{21}$ Max More, "Transhumanism: A Futurist Philosophy," 1990 http://www.maxmore.com/ transhum.htm. Some consider that transhumanism is a negation of modern humanism, almost antihumanism. Even authors associated with transhumanism indicate that humanism is "the idea by which constant identification with a quasi-mystical universal 'human nature' produces great cultural achievements, which serve to promote the cohesion of humanity in general." Stefan Herbrechter, Posthumanism (London: Bloomsbury, 2013), 12.

${ }^{22}$ Russell Blackford, "H+:Trite Truths about Technology: A Reply to Ted Peters," MetaNexus, http://www.metanexus.net/essay/h-trite-truths-about-technology-reply-ted-peters. 
It is also possible to show that transhumanism expresses itself at three different levels. Initially it develops a philosophical and metaphysical posture. At that level, "the transhumanist sees a world in a 'process of evolutionary complexification toward ever more complex structures, forms, and operations." "23 It might be assumed that because of the inherent complexity of the world, transhumanism would tend to recognize the limits of humanity. But it is not ready to concede the nonsufficiency of humanity. Instead, at a psychological level, it implies that "human beings are 'imbued with the innate Will to Evolve - an instinctive drive to expand abilities in pursuit of ever-increasing survivability and well-being." 24 This stress on the will is reminiscent of Nietzsche, and some transhumanist thinkers do not hesitate to reclaim the "philosopher with the hammer." 25 Of course neither the metaphysical dimension nor the psychological dimension would be complete without the third level, ethics. In fact, the first two levels "lead to the ethical level, where 'we should seek to foster our innate Will to Evolve, by continually striving to expand our abilities throughout life." 26 Transhumanism, on this last point, can be considered as technological hedonism. ${ }^{27}$ Because of the combination of these three levels, as well as the cultural and political implications of transhumanism, this topic is highly significant for Christian apologetics.

Transhumanism can thus be seen as faith in the necessary progress of human beings to improve individuals and the human species itself. Progress will be made possible by politicosocial and technological advances within a horizon that exceeds the boundaries that have historically limited the definition of the human person. Ultimately, it will literally make the future of humanity transhuman. ${ }^{28}$

${ }^{23}$ Ted Peters, "H-: Transhumanism and the Posthuman Future: Will Technological Progress Get Us There?," MetaNexus, September 1, 2011, http://www.metanexus.net/essay/h-transhumanism-and-posthuman-future-will-technological-progress-get-us-there.

${ }^{24}$ Ibid.

25 The Nietzschean paternity of transhumanism is open to debate. Bostrom, for example, strongly denies arguments concluding that the German philosopher can legitimately be considered a distant ancestor of the movement. Stefan Sorgner maintains that the transhumanist stress on the "non-fixity of human nature" is a clear Nietzschean perspective. See Bostrom, "A History of Transhumanist Thought," 4-5; Stefan Sorgner, "Nietzsche, the Overhuman, and Transhumanism," Fournal of Evolution and Technology 20.1 (March 2009): 29-42, http://jetpress.org/v20/sorgner.htm.

${ }^{26}$ Peters, "H-: Transhumanism and the Posthuman Future."

${ }^{27}$ Cf. Hubac, "Science sans conscience," 9-26, esp. 23-25.

${ }^{28}$ Gabriel Dorthe mentions three common points to all forms of transhumanism: (1) research to improve all dimensions of human life by technical progress, including new rights and values; (2) an enthusiastic vision of technical progress; (3) and an interest for debating the importance, use and future of these techniques in order to highlight potential risks. Dorthe, "Visions, histoire et géographie du transhumanisme." 


\section{A Radical Overcoming}

Being transhuman, this movement offers a radical and holistic overcoming. As Max More describes it, "becoming posthuman means exceeding the limitations which define the less desirable aspects of the 'human condition.' Posthuman beings would no longer suffer from disease, ageing, and inevitable death (but they will face other challenges)." ${ }^{29}$ What is at stake is not so much a quantitative improvement of human nature, but a qualitative one. As a symbol of this perspective, More comments on his change of name: "It seemed to really encapsulate the essence of what my goal is: always to improve, never to be static. I was going to get better at everything, become smarter, fitter, and healthier. It would be a constant reminder to keep moving forward." ${ }^{30}$ The objective of radical overcoming is obvious here.

First, transhumanism seeks to transcend theological and philosophical limits. According to More's extropian principles, transhumanism prefers "reason over blind faith and questioning over dogma. Remaining open to challenges to our beliefs and practices in pursuit of perpetual improvement. Welcoming criticism of our existing beliefs while being open to new ideas." ${ }^{\prime 31}$ Classical philosophies are challenged by transhumanism, which presents itself as radical materialism and pragmatism. Transhumanist science would then aim only at determining what is most fitting for the world. Transhumanism is the radical end, the surpassing of all philosophies that More calls "pancritical rationalism." This theory of knowledge holds that everything should be criticized because everything evolves: the body, truth, society, even personality. Once this first limitation has been overcome, transhumanism promotes a second step beyond the realm of the cognitive and the bodily.

These forms of technological overcoming eventually lead transhumanism to proclaim four "ends": of disease, of objective law, of gender, and of humanity. The first is at the heart of the transhumanist project: the end of disease, suffering, and aging. All those associated with the movement do not hold the same attitude on this point. Some defend abolitionism and longevity, arguing for an extension of human life as well as for the moral obligation to abolish suffering and disease. However, they also believe that death will not be overcome. ${ }^{32}$ Others hold to immortalism and expect that

\footnotetext{
${ }^{29}$ Max More, "The Philosophy of Transhumanism," in Max More and Natasha Vita-More, eds., Transhumanist Reader: Classical and Contemporary Essays on the Science, Technology, and Philosophy of the Human Future (Oxford: Wiley \& Sons, 2013): 3-17, here 4.

${ }^{30}$ Ed Regis, "Meet the Extropians," Wired, October 1994, https://www.wired.com/1994/10/ extropians/.

${ }^{31}$ More, "Extropian Principles."

32 Ibid. See More, "The Philosophy of Tranhumanism," 4; Bostrom, "A History of Transhumanist Thought"; Natasha Vita-More, "Life Expansion Media," in The Transhumanist Reader:
} 
nanomedicine will lead to the extinction of suffering and aging, rendering humans almost eternal. As noted above, Aubrey de Grey is a prominent promoter of this position.

Yet one of the major sociopolitical conclusions of transhumanism is that the programmed end of disease cannot be achieved in the current political context. Hence it is necessary to overcome what they sometimes refer to as "objective law." This touches upon the nature of political transhumanism-whether democratic or libertarian. These two political manifestations of transhumanism, while holding to different views, both try to show that transhumanism is the preferred means by which each of us will reach the fullness of well-being through the rational control of environment and society. If objective law must be overcome, it can be done in several ways. The first is "upwing" transhumanism represented by FM-2030: this brand of political transhumanism seeks to overcome left-right political dialectics by promoting institutional unity and by developing a global language and citizenship. ${ }^{33}$ If FM-2030's political bent has not been very influential hitherto, the opposite can be said of Donna Haraway's "Cyborg Manifesto." Written in 1984, this article is not really a true transhumanist manifesto; rather, as the subtitle clearly says, it is about "Science, Technology, and Socialist Feminism in the 1980s." ${ }^{34}$ However, because of its many implications, it can still be included in the transhumanist canon, and its sociopolitical significance should not be underestimated. ${ }^{35}$ Despite the links some see between the political left and transhumanism, "the fact that a left futurism has been so slow to emerge is somewhat surprising, since technoutopianism, atheism, and scientific rationalism have been associated with the democratic, revolutionary and utopian left for most of the last two hundred years." ${ }^{36}$ But political transhumanism can also take other forms such as cyberpunk-with egalitarian accents promoting a via media between capitalism and socialism-or a libertarian version that advocates a personal right to change and increase one's own body — thus promoting a very subjective definition of law. ${ }^{37}$

Classical and Contemporary Essays on the Science, Technology, and Philosophy of the Human Future, ed. Max More and Natasha Vita-More (Oxford:Wiley \& Sons, 2013): 73-82.

${ }^{33}$ FM-2030, Up-Wingers (New York: Popular Library, 1977).

${ }^{34}$ Donna Haraway, "A Cyborg Manifesto: Science, Technology, and Socialist-Feminism in the Late Twentieth Century," in Simians, Cyborgs and Women: The Reinvention of Nature (New York: Routledge, 1991): 149-81, Georgetown University, http://www9.georgetown.edu/faculty/ irvinem/theory/Haraway-CyborgManifesto.html.

35 The link between this form of social criticism and transhumanism has yet to be specified, though. Cf. Hughes, "The Politics of Transhumanism."

${ }^{36}$ Ibid.

37 This current in particular is represented by James J. Hughes's Citizen Cyborg (Cambridge: Westview, 2004). 
With the end of disease and objective law, the final overcoming of gender and human nature would also be guaranteed. Here, transhumanism manifests strong ties with postgenderism and with the wider circle of posthumanism. ${ }^{38}$ Postgenderism, or even gender studies, is a cultural and social philosophy aimed at the voluntary elimination of biological genders through the use of postmodern philosophies, biotechnologies, and new assisted reproductive technologies. Here Haraway's "Cyborg Manifesto," along with "queer futurism," is an important part of literary science fiction close to LGBTQ movements. For others, the overcoming of gender, and therefore social equality control, can only come about through the development of artificial life. In 1970 Shulamith Firestone was already arguing that "patriarchal society" could only be abolished by creating artificial wombs, freeing women from an imaginary role implemented by a masculine-conditioned reading of their own physiology. ${ }^{39}$ Although the interaction between transhumanism and postgenderism is rather vague, technological and social promises made by transhumanism could be catalysts for a dynamic and synthetic combination of these movements.

Finally, at this stage, the overcoming of the human, the end of the human species, would be consummated. This direction, supported by a large majority of transhumanist movements, is a particular focus of extropianism, whose founding principles advocate a proactive approach to human evolution, advancing it through the integration of new technologies. Kurzweil offers an advanced version of this position, predicting the coming of "the Singularity." This last notion is defined as the point after which technological growth will be self-exponential and self-directed. After the Singularity, humans will witness the birth of a new species, yet undefined. ${ }^{40}$

\section{From Technology to Redemption}

As we have seen, transhumanism grants an almost limitless value to technology. However, the question remains: Why do emerging technologies

38 The difference between post- and transhumanism remains to be clarified. In this article, posthumanism is considered a broader philosophical and cultural circle than transhumanism.

${ }^{39}$ Shulamith Firestone, The Dialectic of Sex: The Case for Feminist Revolution (New York: William Morrow, 1970). This conclusion is also discernible in the opinion of Marc Roux who believes that transhumanist philosophy and "Surrogacy" are part of "the same logic that can allow us to make ourselves as independent as possible ... of our body." Marc Roux, "Conclusions," TransVision 2014, http://www.youtube.com.

${ }^{40}$ In his book The Singularity Is Near (London: Penguin, 2005), Kurzweil speaks of Singularity as a near universal transcendence (388-90). However, we must not understand "transcendence" in a theological sense but as the affirmation of the sublimation, the intelligent transformation of the whole universe. 
nourish so many futuristic and alarmist fantasies? One reason, it seems, lies in the almost religious or redemptive nature of the movement. Underlying this technological philosophy of redemption is an almost technological ontology highlighted very early in the history of its development. As early as 1968 the psychologist and historian of science Serge Moscovici wrote in his Essai sur l'histoire humaine de la nature (Essay on the Human History of Nature) that with cybernetics the need for human agency became, for the first time, superfluous. Others add that for transhumanism, "humans should (or should be permitted to) use technology to remake human nature," so legitimizing the redemptive nature of transhumanism's technological hopes. ${ }^{41}$ In particular, cybernetics would proclaim the emergence of a technique that would be self-evolving. Hence the conclusion of the NeoHumanitas think tank:

Most versions share the assumption that technology is involved in a spiraling dynamic of co-evolution with human development. This assumption, known as technogenesis, seems to me compelling and indeed virtually irrefutable, applying not only to contemporary humans but to Homo sapiens across the eons, shaping the species biologically, psychologically, socially and economically. ${ }^{42}$

We could as easily say that, psychologically, a human frontier was overcome: technology was no longer mediation with an environment external to human beings; instead, since it is now within the body, it is used as mediation between the person and his or her own self.

Here, transhumanism takes on an almost theological connotation. It is in fact a theology of creation in which the universe is to be improved and "made alive" by intelligence and human creativity - all the while being of the mind that human potential for development is inherent in matter. ${ }^{43}$ Transhumanist anthropology is partly based on a disputed interpretation of Nietzsche. For those who discern a positive influence of the German thinker, human nature is not a given, but something everyone should be creating. So appears a

${ }^{41}$ Heidi Campbell and Mark Walker, "Religion and Transhumanism: Introducing a Conversation," fournal of Evolution and Technology 14.2 (August 2005), 1. See also Nick Bostrom, "Transhumanist Values," 2005, http://www.nickbostrom.com/ethics/values.html.

${ }^{42}$ Katherine Hayles, "H-:Wrestling with Transhumanism," MetaNexus, September 1, 2011, http://www.metanexus.net/essay/h-wrestling-transhumanism.

43 "What we find in transhumanists' predictions is the use of the doctrine of progress. Transhumanists think that progress, understood as an improvement over time, is inherent in nature and inherent in culture." Peters, "H-:Transhumanism and the Posthuman Future." 
new paradigm about the future of humanity, based on the assumption that human nature, which up to now has been considered sacred and untouchable, does not exist. Human nature is not an untouchable dogma. The human species is malleable and fundamentally improvable. ${ }^{44}$

However, an important difference remains between transhumanism and Nietzsche: the latter would never have implied that human beings could or even should be disembodied. Now, as Ted Peters has noted, transhumanism "assumes that human intelligence and personality can be disembodied." 45 Out of this theology of creation emerges a doctrine of inherent sin: matter, although subject to humankind, contains a deep flaw, an imperfection. The fallibility of the world, and consequently of humanity, is manifest in a profound dissatisfaction. This frustration finds its root in natural, social, and psychological conditions sometimes considered debilitating. Human sin is defined as not being what one desires to be-and should become. Here again the religious nature of transhumanism appears clearly.

Finally, transhumanism also offers redemption through the will to technological acceleration. Thus, Kurzweil's statement that "the machines are an expansion of our own intelligence" is not a mere utopian affirmation about the power of technology, but rather an attempt to redeem a humanity dissatisfied by itself. ${ }^{46}$ Of course, the means through which this redemption can be accomplished are diverse (sociopolitical, cultural, and technological), but they all share a holistic dimension. Thus human redemption will be cosmic, or it will not be. The conditions of technological redemption also lead to a distinction within transhumanism between those who anticipate slow and difficult progress through a kind of purgatory and those who expect a "critical leap" in which change will be fast and radical, almost instantaneously transferring us from our current hell to the paradise of singularitarian bliss. ${ }^{47}$

\section{The Anthropological Challenge of the Twenty-First Century}

The vast majority of Christian traditions have criticized transhumanism, even though some remain more appreciative than others. In The Transhumanist Wager, a science-fiction novel by Zoltan Istvan, Christians-fundamentalists, of course - are the main opponents of transhumanists and, led by the elated Reverend Belinas, begin a guerilla war against transhumanist

\footnotetext{
${ }^{44}$ Vincent Schmid, "La foi au défi du transhumanisme," Évangile et liberté 234 (December 2009): 10-15, here 12 .

45 Ted Peters, "The Soul of Transhumanism," Dialog 44.4 (Winter 2005), 381-95, here 385.

${ }^{46}$ Ray Kurzweil, "In-Depth with Ray Kurzweil," C-Span, November 5, 2006, https://www. c-span.org/video/?194500-1/depth-ray-kurzweil.

${ }^{47}$ Against Gabriel Dorthe, it seems that transhumanism promises an eschatology.
} 
interests. ${ }^{48}$ This is symptomatic of how many transhumanists view religion, especially the Christian religion. However, it must not be thought that transhumanism has found no positive echo in Christian theology. ${ }^{49}$ Indeed, with its emphasis on the fight against human fallibility and the potential evolution of the human species, it is not surprising that transhumanism found a positive reception in theological circles close to radical evolutionism - mostly associated with Teilhard de Chardin, Alfred North Whitehead, and process theology. Whatever theological echo transhumanism found in Christianity,

it is likely that [transhumanism] will have an important place in the intellectual debate in the coming years. Indeed nothing seems now to replace the scientific model that informs our society so deeply. And nothing can prevent it from nourishing very stubborn hopes." ${ }^{.50}$

An apologetic response and dialogue with transhumanism therefore seems necessary. In some countries, like France, this movement is only in its infancy. However, we should not forget that it is an important sociocultural phenomenon. Very few articles or books are written from a theological perspective; most of the literature originates in transhumanist circles, coming from the transhumanists themselves, as for example the articles in the Fournal of Evolution and Technology. ${ }^{51}$ The wider Christian community remains largely unaware of the challenge. This lack of interaction, in a Western world much less turned towards religion, encourages transhumanists to look at messianic science for answers. Hence the conclusion of Ted Peters: "The transhumanist movement seeks to fill the widening cultural void in Western civilization due to the disintegration of the former religious glue that held us together in a common spirit." 52

${ }^{48}$ Zoltan Istvan, The Transhumanist Wager (Futurity Imagine Media, 2013). With reference to the three laws of Asimov's robotics, Istvan proposed "three laws" of transhumanism: (1) "A transhumanist must safeguard one's own existence above all else"; (2) "A transhumanist must strive to achieve omnipotence as expediently as possible - so long as one's actions do not conflict with the First Law"; (3) "A transhumanist must safeguard value in the universe-so long as one's actions do not conflict with the First and Second Laws." Zoltan Istvan, "The Three Laws of Transhumanism and Artificial Intelligence," Psychology Today, September 29, 2014, https://www.psychologytoday.com/blog/the-transhumanist-philosopher/201409/the-three-lawstranshumanism-and-artificial-intelligence.

49 The United Protestant Church of France promptly launched a reflection on transhumanism after Vincens Hubac proposed a motion at the National synod at Avignon in 2014. In decision no. 34, the Synod decided to initiate further reflection.

${ }^{50}$ Schmid, "La foi au défi du transhumanisme," 12.

${ }^{51}$ Notable exceptions are the special issues of Évangile et liberté and of Foi et vie.

52 Peters, "H-: Transhumanism and the Posthuman Future." 


\section{Systematic Theology Facing Transhumanism}

To promote interaction with transhumanism, focus on precise areas is necessary. The first area of interaction with transhumanism is systematic theology. In fact, several studies offer a transhumanist reinterpretation of the main aspects of the Christian faith. ${ }^{53}$ Three theological issues need addressing in a contextualized way. First, particular attention should be given to the type of evolutionism promoted in theology. The debate between creationism and evolutionary theism is certainly not over. However, interaction with transhumanism suggests that a move away from an internal evangelical debate to an external debate with materialistic evolutionism would be beneficial. This question is highly anthropological and requires more dialogue and less emotionally charged debate between the two aforementioned versions of creationism. In this context, we need to address the question of death and suffering and to be sensitive to this essential quest of transhumanism: "If it is natural to die then let's get rid of nature. Why submit to tyranny? We must rise above nature. We must refuse to die." ${ }^{54}$ In this emotive context, the normativity of human nature becomes one of the major systematic issues. ${ }^{55}$

Furthermore, the theology of the incarnation could also benefit from a reframed formulation with reference to transhumanism. This theological locus has received increasing interest from different theological perspectives. For example, Jeanine Thweatt-Bates has made a reasoned presentation for a christological formulation taking into account the contributions and radical philosophical intuitions of transhumanism. However, her contribution also involves a significant reinterpretation of classical Christology, based on an ambiguous view of the reality of Christ's divinity. ${ }^{56}$

Finally, eschatology needs integration into systematic reconsiderations. If transhumanism is a theology of redemption, it is also an eschatology. In fact, it offers redemption from a life of frustration and limitation because it hopes for a completely new and transformed cosmic reality. In that new world, humanity, even if it does not become the measure of all things, will at least be individually its own measure. Beyond the Singularity lies the promised land, or rather, the promised "transhuman" condition. Faced with

\footnotetext{
${ }^{53}$ See the works of Philip Hefner, Jeanine Thweatt-Bates (Cyborg Selves) or the publications of the Christian Transhumanist Association (http://www.christiantranshumanism.org).

${ }^{54}$ Quoted by Benjamin Tiven, "The Future Takes Forever Becoming FM-2030," Bidoun, http://bidoun.org/articles/the-future-takes-forever. Until recently, this was one of the key phrases on FM-2030 site, http://fm2030.us.

${ }^{55}$ Bernard Baertschi, "L'obsolescence programmée de la nature humaine," Foi et vie 114.4 (December 2014): 46-61, here 48-52.

${ }^{56}$ Jeanine Thweatt-Bates, Cyborg Selves: A Theological Anthropology of the Posthuman (Farnham, UK: Ashgate, 2012), 175-92.
} 
this challenge, Christian theology needs an eschatology rooted in the theology of creation. Eschatology is not to be considered as a mere appendage to redemption, but a consequence of the creative act of God.

\section{Apologetics Responding to Transhumanism}

It is necessary for systematic theology to interact with transhumanism because apologetics builds on that primary discipline. The apologetic challenge of transhumanism must somehow encourage greater proximity between apologetics and systematic theology, even developing a new type of systematic and philosophical commitment. Only if systematic theology interacts with transhumanism can an apologetics-based answer to this twenty-first century challenge be developed. The following points may be indicated. First, an apologetic response to transhumanism could center on the concepts of longevity and immortalism. The ideal (or idol) of mastery and annihilation of "human time" is an apologetic question. ${ }^{57}$ Ultimately, transhumanism must answer as to whether human embodiment in time is not de facto a necessary and beneficial condition of humanity.

Further, the two connected domains of human cognition and emotions are the object of transhumanist interest. Apologetics can also provide the foundations without which such human abilities as memory, analogical reasoning, and concentration cannot be explained in a satisfactory way. Here the debate will most likely oppose two radically different worldviews: materialistic and supernatural, atheistic and biblical-theistic. In addition, the ability to take pleasure in life and to respond appropriately to various situations is also a matter to be addressed apologetically. An apologetic of the emotions, human pathos, although difficult to develop, should be formulated in the context of a response to transhumanism. The apologist must therefore simultaneously strive to value human emotions while critically engaging transhumanism, particularly as the latter considers that one of the roots of current suffering lies in human emotions leading to wrong decision making.

Moreover, it is impossible to ignore the ethical stance that theology, and thus the church, has to make. Of course, the contours of transhumanist ethics must be traced, although these are not yet completely clear, and some may doubt they will ever be. Transhumanism is more concerned with ethical rejections than with ethical affirmations. From a theology of the

\footnotetext{
${ }^{57}$ One fact remains, as Ted Peters indicates: "Our redemption through resurrection into a new creation does not match the physical longevity or cybernetic immortality." Ted Peters, "Progress and Provolution:Will Transhumanism Leave Sin Behind?," in Ronald Cole-Turner, ed., Transhumanism and Transcendence: Christian Hope in an Age of Technological Enhancement (Washington, DC: Georgetown University Press, 2011), 73.
} 
body to procreation, or to obvious social issues concerning justice, transhumanism raises countless ethical questions..$^{58}$ One case in point: if human growth is to be part of tomorrow's economic landscape, what are we to make of the following possible scenario?

We could even speculate about the members of the privileged stratum of society eventually enhancing themselves and their offspring to a point where the human species, for many practical purposes, splits into two or more species that have little in common except a shared evolutionary history.... The non-privileged would remain as people are today but perhaps deprived of some their self-respect and suffering occasional bouts of envy. ${ }^{59}$

This quotation, penned by a major transhumanist author, illustrates that, although they are aware of potential problems, their answers remain idealistic, relying on a belief in the inherent goodness of human nature.

Finally, apologetics must respond to transhumanism's technological idealism. In this respect, the work of Jacques Ellul encourages criticism of the way in which technology inexorably leads human beings to redefine themselves. ${ }^{60}$ While transhumanism proclaims that technological control is desirable and that humans would remain in control of things and themselves, Ellul constantly points out that it is impossible to anticipate what the real consequences of technological change might be. By becoming an all-powerful mediator, technology mutates, incorporating into itself the remains of a humanity that has lost its identity. ${ }^{61}$

\section{Conclusion}

As well as being a systematic and apologetic question, transhumanism is an eminently pastoral problem. Its therapeutic aspirations might find a critical echo in pastoral theology practice, opening a way to a holistic renewalsomething transhumanism also seeks. The hope of a world without pain or suffering must also challenge us to better minister to and increasingly manifest compassion in a world obsessed with the promise of an accessible earthly paradise. In this area, creative propositions remain unexplored.

58 Cf. Jean-Michel Besnier, Demain les posthumains (Paris: Hachette, 2009), 206-7.

${ }^{59}$ Nick Bostrom, "Human Genetic Enhancements: A Transhumanist Perspective," The Fournal of Value Inquiry 37.4 (2003): 493-506, http://www.nickbostrom.com/ethics/genetic. html.

${ }^{60}$ See for example Joël Decarsin, "Regard ellulien sur le transhumanisme," Foi et vie 111.2 (June 2012), Technologos, http://technologos.fr.

${ }^{61}$ Sci-Fi fans will benefit from reading Maurice Dantec, Grande fonction (Paris: Albin Michel, 2006). 
Pastoral care has to be developed to address a transhuman context. In this sense, apologetic and pastoral counseling overlap and make understanding transhumanist philosophy a prerequisite for an appropriate response to this "techno-redemptive" movement.

We must end this introductory reflection with the importance of listening and understanding - both central to pastoral counseling and apologetics. It would be a fatal mistake to put aside, discredit, or attack transhumanism thoughtlessly. If confrontation is necessary, it must be done with relevance. But that can only be done if, beforehand, the questions raised by this movement have been heard and understood. Thus, a certain empathy is necessary before we can hope to critically engage this philosophical and cultural movement. Perhaps transhumanism might then have a positive impact on theology, requiring greater inner consistency on our part, but also careful thought and a more engaged attitude with contemporary challenges. In this sense, Jean-Michel Besnier has rightly concluded that transhumanism "radicalizes and focuses our attitudes: welcoming as an alter ego the person who is different from myself, because that person does not belong to my horizon of meaning or my definition of the human." ${ }^{\prime 2}$ The interaction with transhumanism does not imply, however, acceptance, but recognition of its current importance. To avoid apologetic dialogue and criticism would be a tragic mistake that would harm the future of Christ's church.

This should not obscure the serious problems or dangers inherent in transhumanism. In promising radical transformation of human nature it promotes, without acknowledging it, a radical negation of everything that defines the human person-especially human dignity, integrity, responsibility, and freedom. ${ }^{63}$ By contrast, faith in a personal God, transcendent and triune, a God who took on our nature, remains the necessary foundation for the defense of a true and radical humanity.

${ }^{62}$ Besnier, Demain les posthumains, 208.

${ }^{63}$ See the conclusions of Hottois in "Le transhumanisme entre humanisme et posthumanisme," 43-44. 


\title{
The Black Church's Response to the Racialization of Abortion in America
}

\section{EMMITT CORNELIUS JR.}

\begin{abstract}
The "racialization" of abortion in America is a concept that draws attention to the fact that blacks (and to a lesser extent, Latinos) are disproportionately represented by abortion statistics as a result of an aggressive racist agenda in America to control the black population through attrition. More so than any other institution, the black church is positioned to confront this crisis as its ministers reclaim their shepherding role to protect their community's most vulnerable members. This starts with a commitment to traditional family values that are derived from a robustly biblical concept of family, marriage, sex, and child-bearing.
\end{abstract}

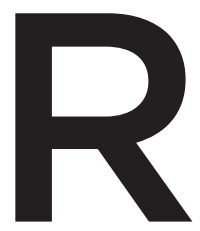

ace and abortion are perhaps two of the most polarizing and controversial topics in the United States today. However, when the two are combined, as I believe they are in the current abortion debates, we are faced with one of the most explosive and divisive issues in modern American history. Of course, pro-abortion advocates and providers like Planned Parenthood deny any connection between abortion and race. Instead, they attribute significantly higher abortion rates in the black community to higher rates of unplanned 
pregnancies. This is explained by inadequate family planning services in low-income and minority communities and the destabilization of black families due to poverty, crime, poor education, high incarceration rates, and violence, which make continuing a pregnancy a less desirable option for pregnant black women.

Statistically, it is hard to ignore the racial demographics of abortion. How can one deny the racialization of abortion in America when in some states more black babies are aborted than born? when black children are aborted at nearly four times the rate as white children? when a purported 79 percent of Planned Parenthood's clinics are located in black or minority neighborhoods (making abortions easily accessible to pregnant black women more so than white women)? when African American teenagers abort their babies at five times the rate of their white counterparts? I am not denying the higher incidence of unplanned pregnancies among African Americans or that black women apparently choose abortion as an option more frequently than women of other races. But neither am I ignoring the reality that, according to these race-based statistics, abortion is being aggressively marketed to the black community as another form of birth control (over against aggressively promoting "life affirming" options such as parenthood or adoption).

John Piper, a white pastor and theologian, perceives the injustice of the abortion industry in America. He writes, “The de facto effect (I don't call it the main cause, but net effect) of putting abortion clinics in the urban centers is that the abortion of Hispanic and Black babies is more than double their percentage of the population. Every day 1,300 black babies are killed in America. Seven hundred Hispanic babies die every day from abortion. Call this what you will-when the slaughter has an ethnic face and the percentages are double that of the white community and the killers are almost all white, something is going on here that ought to make the lovers of racial equality and racial harmony wake up."1 This injustice led another author to comment that abortion in America "is by no means an equal opportunity employer."2

Some readers may accuse me of exaggerating this point, but consider the following statistics about abortion in the black community. According to the Center for Disease Control, black babies comprised nearly 36 percent of all abortions done in the US between 2007 and 2010. This number is staggering considering the fact that blacks made up only 12.8 percent of the

1 John Piper, "When Is Abortion Racism?," Desiring God, 21 January 2007, http://www. desiringgod.org/messages/when-is-abortion-racism.

2 “Abortion and Race," Abort73, http://www.abort73.com/abortion/abortion_and_race. 
total United States population during this period. Since 1973, nearly 16 to 17 million black babies have been aborted, which has led one author to refer to this loss of life as the "Black Infant Holocaust." Michael Novak, a noted philosopher, journalist, novelist, and diplomat comments that "since the number of current living Blacks (in the US) is 36 million, the missing 16 million represents an enormous loss, for without abortion, America's Black community would now number 52 million persons. It would be 36 percent larger than it is. Abortion has swept through the Black community like a scythe, cutting down every fourth member."3

Astonishingly, almost half of all African American pregnancies end in abortion. It has been estimated that on average 1700-1800 black babies are aborted every day in the United States. ${ }^{4}$ Black teenagers between 15 and 19 years old have an abortion rate of 41 per 1000 women, which is more than twice the national average. Since 1973, more blacks have died from abortion than from AIDS, violence, accidents, cancer, and heart disease combined. This disturbing trend has led the Rev. Clenard Childress, founder of the website Blackgenocide.org, to observe that "the most dangerous place for an African-American is in the womb." Indeed, if I may borrow a statement from best-selling author David Platt and amend it somewhat to address the subject at hand, "For all the pressing social issues [in the black community], abortion poses the most clear and present danger to [black] people on a daily basis."6

I believe that the African American church has much to offer the black community in the struggle for the civil rights of the unborn in spite of its long history of silence on this issue. As Elijah J. Israel observes about the black experience in America, the black church, "more than any other institution in society," is "positioned" to confront a morally decadent society in which America's abortion culture thrives. ${ }^{7}$ But before the black church can effectively step into this role it must embrace a more biblical understanding of the role of its ministers/shepherds as well as of its mission and calling to be light in the world. In this article I will suggest some practical steps to

3 See Black Genocide, http://www.blackgenocide.org/black.html.

4 Elisha J. Israel, in Killing Black Innocents: The Program to Control African American Reproduction (self-published, 2014), makes the excellent point that between 1882 and 1986, otherwise known as the Lynching Century, the Tuskegee Institute recorded 3,466 lynchings of African Americans. Today, that number is easily surpassed in a couple of days through abortion (96).

5 See Black Genocide, http://www.blackgenocide.org/black.html.

6 The actual quote is, "For of all the pressing social issues addressed in this book, abortion poses the most clear and present danger to the most people on a daily basis." David Platt, $A$ Compassionate Call to Counter Culture (Carol Stream, IL: Tyndale House, 2015), 57.

7 Israel, Killing Black Innocents, 97. 
help the black church — starting with its ministers - rethink its position on abortion, with the aim of helping it to emerge as a powerful defender of the right to life of all unborn children, but especially black children, who are the main target of the abortion industry.

It will become clear in the following discussion that I am writing from the conviction that abortion in black America is a spiritual and moral problem more so than an economic and social one. Therefore, I am addressing this problem from the perspective that to fight against abortion is to engage the satanic forces that energize America's "culture of death," which has succeeded in normalizing abortion on demand. Such engagement requires the deployment of spiritual means and methods if victory is to be assured.

\section{The Silence of Black Shepherds}

When Margaret Sanger, the founder of Planned Parenthood, conspired to saturate the black community with her birth control gospel, she turned to black ministers for help. Although Sanger was not a religious person, she and her coconspirators were astute enough to realize that the black minister was incredibly influential in the black community. And although the term "shepherd" probably never crossed Sanger's mind, she apparently understood the power of the concept when she recruited black ministers to do her dirty work.

In the world of the Bible, the shepherd is the predominant image used to describe the character and work of the individuals God calls to lead his people. In the Old Testament, Israel's shepherds were mainly its prophets and priests (Jer 2:8); in the New Testament, the shepherds were the "pastors" of local churches, who were also referred to as "elders" and "bishops" (Acts 20:17, 28).

The shepherd imagery is a good one for understanding the God-given responsibility of spiritual leaders. As everyday shepherds were responsible for feeding, guiding, and protecting the sheep under their care, spiritual shepherds feed, guide, and protect God's spiritual flock, whose care has been entrusted to them.

But occasionally God chided his spiritual leaders for not being good shepherds. Evidently, they failed to adequately feed, guide, and protect God's flock. In Old Testament times, God sent faithful prophets to warn the people not to follow these misguided leaders. For example, God spoke through his prophet Jeremiah against "the shepherds who care for my 
people" in Judah (Jer 23:2). ${ }^{8}$ God indicted Judah's shepherds for failing to care for his flock: "You have scattered my flock and have driven them away, and you have not attended to them." A shepherd who left his flock unattended even for a moment exposed the sheep to all sorts of dangers, not the least of which were predators. This was also true in the case of God's spiritual flock. When left unattended and unguarded through spiritual neglect, God's people were prone to wander from the truth and to become prey for spiritual predators, namely the idols of the surrounding nations.

Jeremiah also spoke out against leaders who pretended to speak for God: "Do not listen to the words of the prophets who prophesy to you, filling you with vain hopes. They speak visions of their own minds, not from the mouth of the Lord. They say continually to those who despise the word of the Lord, 'It shall be well with you'; and to everyone who stubbornly follows his own heart, they say, 'No disaster shall come upon you"' (Jer 23:16-17). Rather than warning God's people of impending doom and destruction (exile), Judah's shepherds assured them that their present course would bring peace, safety, and prosperity.

Similarly, false shepherds were a threat to God's New Testament people, the church. In his tearful farewell speech to the church in Ephesus, Paul warned the elders/shepherds to "Pay careful attention to yourselves and to all the flock, in which the Holy Spirit has made you overseers, to care for the church of God, which he obtained with his own blood. I know that after my departure fierce wolves will come in among you, not sparing the flock; and from among your own selves will arise men speaking twisted things, to draw away the disciples after them" (Acts 20:28-30). In the spirit of the Old Testament prophets, Paul warned these shepherds "to pay careful attention ... to all the flock" because false shepherds were lurking in the shadows waiting for an opportunity to deceive God's sheep. These false shepherds would be marked by their infidelity to the truth of God's Word.

So throughout Scripture the quality that marks a shepherd as belonging to God is his commitment to the Word of God in feeding, guiding, and protecting the flock under his charge. Unfortunately, when Sanger came knocking at the door of the black church, its leadership failed to exercise the kind of thoughtful and faithful shepherding that God requires of his leaders.

\footnotetext{
8 All quotations are from the English Standard Version.
} 


\section{Misguided Shepherds in the Black Community}

The abortion crisis in the black community started with Sanger targeting poor African Americans in the South for birth control, which by that time was the preferred eugenic measure to rid society of black "undesirables." Sanger knew that because the black community was split over birth control she needed the right people to promote it. She turned to black intellectuals such as W. E. B. Dubois and Mary McLeod Bethune to help convince blacks that birth control would bring about social and economic improvement in the black community. But in order to win over blacks to the birth control cause, Sanger concluded that "the most successful educational approach to the Negro is through a religious appeal." So Sanger proceeded to recruit black religious leaders who could persuade blacks that the practice of birth control was in their best interest.

Sanger devised the "Negro Project" in 1939 to accomplish her goal to promote birth control in the black community. Along with several coconspirators, she advocated hiring three to four "colored ministers, preferably with social service backgrounds, and with engaging personalities" to preach the birth control gospel in their own communities. ${ }^{10}$ Sanger's plan worked brilliantly, as black pastors embraced the movement, oblivious to its larger, negative implications. Tragically, the success of the Negro Project continues today, with many black pastors supporting abortion and some even working in tandem with Planned Parenthood. In addition, some black pastors unwittingly support Planned Parenthood and the abortion industry through their inaction and silence. By failing to educate their congregations and the community at large about the evil of abortion and Planned Parenthood, they give the abortion industry a "thumbs-up" to continue exploiting black people. These leaders commit the sin of complicity even though some of them may be conscientiously opposed to abortion. As the saying goes, "Evil flourishes when good men do nothing." Unfortunately, this is true in the black community, as birth control, and now abortion, has drastically curtailed the growth of the black population in America.

On the issue of abortion, then, black pastors have behaved a lot like the misguided shepherds of Judah. Some have misspoken concerning abortion, declaring to the flock, "It shall be well with you," and "No disaster shall

\footnotetext{
9 “Margaret Sanger and the Negro Project," National Black Pro-Life Union, http://www. nationalblackprolifeunion.com/Margaret-Sanger-and-The-Negro-Project.html. Cf. Douglas R. Scott, Bad Choices: A Look Inside Planned Parenthood (Franklin, TN: Legacy Communications, 1992), 22.

10 "Margaret Sanger and the Negro Project."
} 
come upon you." Instead of warning God's people of the immorality of abortion and the genocidal motives behind it, these ministers have assured blacks that Planned Parenthood's idea of "family planning" is the path to "peace, safety, and prosperity" in the black community. Unfortunately, other ministers, though opposed to abortion, have kept silent on the issue either because of fear or misplaced priorities. They, too, have failed to warn the sheep, thus leaving them in harm's way.

So, whether through active participation or silent opposition, on the issue of abortion black pastors have neglected their responsibility to biblically "shepherd the flock of God." They have set the Word of God aside and misrepresented the chief Shepherd under whom they were called to serve and to whom they will one day give an account (1 Pet 5:4). As a result, millions of America's "black innocents" have been killed by abortion. This article is a call to black pastors to repent of their misguided leadership and return to the business of biblical shepherding.

\section{Restoring the Traditional Black Family Model}

Having endangered the sheep by not protecting them from the likes of Sanger — and today, Planned Parenthood-black America's spiritual leaders have a responsibility before God to "break the silence" about abortion and rescue the sheep from the current abortion crisis in the black community. The starting point for this task is resetting the African American moral/ spiritual agenda by restoring the primacy of the "holy book" in the black religious and family experience. As the black minister/shepherd leads his people to rediscover the fullness of biblical truth so that it begins to give shape to a full-blown Christian worldview and a corresponding lifestyle that witnesses to the transforming power of the gospel, the black church will be unleashed by God to be a change agent in the black community. This is the kind of impact the Apostle Paul envisioned when he depicted Christians as people who are "blameless and innocent, children of God without blemish in the midst of a crooked and twisted generation, among whom you shine as lights in the world, holding fast to the word of life" (Phil 2:15-16). As black Christians live according to a biblical worldview in their families and communities, invariably they will have a transforming impact upon the surrounding cultural landscape.

Abortion in the black community is a symptom of a greater social, spiritual, and moral crisis: the disintegration of the traditional black family. I am convinced that the application of a full-blown, Christian worldview to the black family unit will help turn around the present crisis in the black 
community. After all, the practice of aborting black babies would be unthinkable in a community where traditional family values prevail. In the remainder of this article I will explore the concepts of family, marriage, sex, and child-bearing from the perspective of a full-blown Christian worldview. I hope to demonstrate that the black family re-envisioned from a biblical, gospel-centered perspective is precisely what the black community needs in order to liberate itself from an abortion culture that preys on its youngest members.

\section{Family}

Most people would agree that the family is the foundation of civilization (Gen 1:26-28). ${ }^{11}$ According to Tony Evans, the link between the family and civilized society is so strong that "the saga of the nation is the saga of its families written large." ${ }^{\prime 2}$ Or, as another author put it, "If there is a breakdown on this [family] level, it is sure to have a ripple effect throughout other social relationships."13 Correspondingly, the black family is the bedrock of the black community. Therefore, the saga of the black community is the saga of its families written large. In other words, as the black family goes, so goes the black community.

The family unit is not an afterthought in God's plan for the human race-it is central to it. After God made the first man, he declared that it was not good for him to be alone. So God fashioned a counterpart from man's rib, a woman, and gave her to the man (Gen 2:18-25). This marked the institution of the family. Then God commanded the first couple to "Be fruitful and multiply and fill the earth" (Gen. 1:28). By this, God intended the family to expand to include children who would one day start their own families. God would use this process to fill the earth with people who were made in his image.

It is clear from the Bible that the ideal family consists of a husband, a wife, and children. We find this structure embedded not only in the book of Genesis but also in the Apostle Paul's writings, where Paul describes the ideal family as a relationship between Christ and the husband (1 Cor 11:3a), the husband and wife (1 Cor 11:3b), and parents and their children (Eph $6: 1)$. However, no one would deny that the family structure today does not always conform to the biblical ideal. Negative circumstances, such as death, divorce, separation, desertion, same-sex relationships, spousal and child

\footnotetext{
${ }^{11}$ Tony Evans, How Should Christians Vote? (Chicago: Moody, 2012), 15.

${ }^{12}$ Ibid, 16.

${ }^{13}$ Michael S. Horton, The Law of Perfect Freedom (Chicago: Moody, 1993), 185.
} 
abuse, incarceration, absentee fathers, shacking up, and out-of-wedlock births, often present challenges to experiencing the family model as God instituted it. Notwithstanding, recovering the biblical family nucleus is the solution to strengthening communities and nations.

The need to reform family values is especially acute in the black community. The late Daniel Patrick Moynihan warned the nation almost fifty years ago that the black family was teetering on the brink of disaster. In a riveting sentence from his controversial 1965 study, "The Negro Family: The Case for National Action," Moynihan asserted, "At the heart of the deterioration of the fabric of Negro society is the deterioration of the Negro family." 14 Moynihan perceived that crippling problems in the black community were deeply rooted in the disappearance of the nuclear black family. (A more accurate assessment is that the demise of the nuclear black family in some respects stemmed from racist government policies that contributed to the "crippling problems" of poverty, joblessness, criminal profiling, mass incarceration, inferior schools, single-parent households, and other social ills. Social narratives that blame black people for all the problems in their communities are patently false.) At the time of Moynihan's report, 25 percent of black babies were born out of wedlock. The condition of the black family fifty years later confirms Moynihan's bleak analysis, as the situation in black America has worsened. For example, only 17 percent of black children age seventeen and older live in a family where their biological parents are married. (The figure is 54 percent for white teenagers.) ${ }^{15}$ And today over 72 percent of black babies are born out of wedlock, exceeding that of most other groups: 17 percent of Asians, 29 percent of whites, 53 percent of Hispanics, and 66 percent of Native Americans. ${ }^{16}$

The condition of the family in the black community will continue to deteriorate unless the black church steps in and does something about it. I am proposing that the black church's response to this problem is to become intentionally "pro-family." This means that the black church must promote traditional family values 365 days a year through teaching, counseling, support groups, mentoring, and constant modeling of Christian thought

${ }^{14}$ Office of Policy Planning and Research, United States Department of Labor, "The Negro Family: The Case For National Action," March, 1965, http://web.stanford.edu/ mrosenfe/ Moynihan's\%20The\%20Negro\%20Family.pdf.

${ }^{15}$ Nigel Boys, "State of Black Family: By Age 17, 83\% of Black Teens Live in 'Broken' Homes,'YourBlackWorld,http://yourblackworld.net/2015/02/17/state-black-family-age-17-83black-teens-live-broken-homes/.

${ }^{16}$ Jesse Washington, "Rate of African American Unwed Mothers Soars to 72 Percent," Blacknews.com, http://www.blacknews.com/news/black_unwed_mothers101.shtml\#.WEW ju_krLIU. 
and behavior. The church must have programs in place to help couples inside and outside the church build strong marriages, restore broken ones, avoid divorce, and provide a stable environment for raising children. The church must also develop a ministry that provides mentoring, well-baby care, practical support, baby-sitting services, and help with adoption (if this option is chosen). "Shacking up," premarital sex, marital infidelity, incest, same-sex relationships, and abortion, all of which are family unfriendly, must be unapologetically denounced as harmful practices. Black males must be mentored from childhood to see that masculinity is not based on fathering children but on being responsible fathers. Regardless of circumstances, black males must recognize their financial and social obligation to care and provide for the children they father. Black churches must also create or support re-entry programs that help ex-felons reintegrate into society and become productive citizens and model family men after their release from prison. As black shepherds place a renewed emphasis on building strong black families, the black church will, like a contagious virus, unleash into the black community a positive value system that is biblical, life affirming, and constructive (rather than destructive).

\section{Marriage}

Marriage is the key to healthy families. Unfortunately, cohabitation-two people of the opposite sex living in a marital-like relationship without the benefit of marriage- has a long history in the black community. At one time frowned upon by black people, cohabitation, also referred to as shacking up or living together, has become an acceptable and even somewhat respectable alternative to marriage.

Because the African American family makeup is so complex, it is difficult to know the exact number of unmarried black couples who "live together," but what is clear is that the practice is expanding widely and today it hardly raises eyebrows in the black community. Even the language has morphed when children are involved: "my baby's daddy" and "my baby's momma" has replaced "my husband" and "my wife."

Some couples choose to cohabit in order to get a feel for what marriage will be like or to gauge compatibility. Other couples live together as a substitute for marriage. Increasingly, though, marriage is losing ground in the black community as the basic family unit. In fact, it has been observed that blacks "are the most uncoupled people in the country," with "the lowest marriage rate of any racial group in the United States." ${ }^{17}$ However, in spite

${ }^{17}$ Joy Jones, “Marriage Is for White People," The Washington Post, http://www.washington- 
of all the practical and self-justifying reasons couples give for cohabiting, the practice is detrimental to healthy families and communities because it flies in the face of God's blueprint for both. God does not stutter in his Word about the importance of marriage. According to Genesis 2, as a precondition of the first couple obeying the commands to "be fruitful and multiply" (have sex and children) and "fill the earth" (create communities and civilizations), God joined the first man and woman in holy matrimony:

So the LoRD God caused a deep sleep to fall upon the man, and while he slept took one of his ribs and closed up its place with flesh. And the rib that the LoRD God had taken from the man he made into a woman and brought her to the man. Then the man said, "This at last is bone of my bones and flesh of my flesh; she shall be called Woman, because she was taken out of Man." Therefore a man shall leave his father and his mother and hold fast to his wife, and they shall become one flesh. And the man and his wife were both naked and were not ashamed. (Gen 2:21-25)

Thus there is a divine order to how God provides for healthy societies: Healthy marriages produce healthy families which produce healthy communities.

But this is only part of the story. There is a deeply theological reason for the emphasis God places on marriage in the Bible. Marriage is a picture of something far greater than union between a man and a woman, as great as that concept is. According to W. Ross Blackburn,

God has given mankind a longing for sexual union. Behind that longing is a longing for marriage. And behind the longing for marriage is a longing for God himself. Many in the world do not recognize a longing for God. But they do recognize a longing for sexual intimacy, of the kind where one can know and be known without shame. Marriage faithfully lived out in the church can speak to this longing." 18

The church has a glorious opportunity to help the culture around it discover its deepest longing for God through marriages that conform to "God's design and purpose." 19 In other words, "marriage is a picture, even a foretaste of the gospel," as it points to the good news that sinners are reconciled into an intimate relationship to God through faith in Jesus Christ. ${ }^{20}$ To the extent that the black church lives out marriage according to God's design it fulfills its calling to "let its light shine in the world." On the other hand, "To

\footnotetext{
post.com/wp-dyn/content/article/2006/03/25/AR2006032500029.html.

${ }^{18}$ W. Ross Blackburn, "Sex and Fullness: A Rejoinder to Dennis Hollinger on Contraception,” fournal of the Evangelical Theological Society 58 (2015): 128.

${ }^{19}$ Ibid.

${ }^{20}$ Ibid., 127.
} 
the extent the [black] church does not live out marriage as God has ordered it is the extent to which [it] misrepresent[s] the gospel in precisely the area where the gospel is most apparent." ${ }^{21}$

\section{Sex}

Israel observes rightly that high rates of unintended pregnancies among blacks betray "a state of moral depravity exist[ing] within the black community." 22 In other words, black people are victims, but not entirely innocent victims, of America's abortion crisis. The only completely innocent victims of this nation's abortion crisis are unborn babies. Let me be clear: in a majority of cases, abortions are the product of unintended pregnancies, and unintended pregnancies are the product of the misuse of sex, and the misuse of sex is the product of sinful choices. Unfortunately, the black church, historically, has not taken a strong stand in this area, and, sadly, some of its ministers have been shining examples of sexual impurity to the flock. Therefore, it is important that the black church understand and embrace sex from a comprehensive biblical worldview.

The first chapter of Genesis reminds the reader of the uniqueness of man's creation: "So God created man in his own image, in the image of God he created him; male and female he created them" (Gen 1:27). Humankind's creation in the image of God as male and female suggests that the human race was created "with capacities for intense sexual pleasure and with a calling to commitment in marriage and continence [self-restraint] in singleness. ${ }^{23}$ In other words, God did not create sex for man's misuse. In fact, sex, like everything else God made, is designed ultimately to bring glory to God.Therefore, "all misuses of our sexuality (adultery, fornication, illicit fantasies, masturbation, pornography, homosexual behavior, rape, sexual child abuse, bestiality, exhibitionism, etc.) distort the true knowledge of God. God means for human sexual knowledge to be a pointer and foretaste of our relationship with him."24

The Bible leaves us with little doubt that the casual misuse of sex "is a chief arena of the brokenness of $\sin .{ }^{25}$ In Romans 1 Paul describes this brokenness in terms of a sexual free-for-all. The key verses (24-27) follow Paul's description of people who refuse to obey and worship the Creator:

\footnotetext{
${ }^{21}$ Ibid., 128.

${ }^{22}$ Israel, Killing Black Innocents, 91.

${ }^{23}$ John Piper and Justin Taylor, eds., Sex and the Supremacy of Christ (Wheaton, IL: Crossway, 2005), 26.

${ }^{24}$ Ibid., 30.

${ }^{25}$ Ibid., 50.
} 
Therefore God gave them up in the lusts of their hearts to impurity, to the dishonoring of their bodies among themselves, because they exchanged the truth about God for a lie and worshiped and served the creature rather than the Creator, who is blessed forever! Amen. For this reason God gave them up to dishonorable passions. For their women exchanged natural relations for those that are contrary to nature; and the men likewise gave up natural relations with women and were consumed with passion for one another, men committing shameless acts with men and receiving in themselves the due penalty for their error.

Here Paul makes it clear that the depth of human sin and rebellion is exhibited in the normalization of sexual deviancy, particularly in the form of same-sex relationships. Those who engage in such activities, Paul warns, "receive the due penalty for their error," discovering to their dismay that "Victoria's Secret" is really "Victoria's Lie."

But notice what Paul identifies as the trigger mechanism for the sexual decadence of human society: people "exchanged the truth about God for a lie and worshiped and served the creature rather than the Creator, who is blessed forever!" Another word for this ultimate exchange of loyalties is idolatry. John Freeman defines an idol as "anything we turn to that makes us feel alive in some sense." 26 Put another way, an idol is anything one substitutes in place of God in the attempt to satisfy the deepest longings of the human heart that God alone can satisfy. Freeman goes on to explain that idolatry is the "default mode" of our sinful hearts. Human beings sin by nature and choice. In fact, as Blackburn observes, at "the most fundamental level ... our nature produces our choices. We inherit a sinful nature from our father Adam so that we are spring-loaded to $\sin . "{ }^{27}$ The most basic form that our sin takes is idolatry, which means that man's natural tendency is to go after counterfeit gods "to replace the real thing." So "sexual sin in any form is an attempt to seek after a grander experience, on par with being overwhelmed and awed by the living God." ${ }^{28}$ When it comes to the misuse of sex, people need to view sex as masking a hidden idol of the heart.

All of this suggests that the high rate of unintended pregnancies (and therefore abortions) in the black community has a much deeper source than "inadequate family planning." The real source is spiritual. It is sinful idolatry. It is bowing to the gods of this age. Therefore, the solution to unintended pregnancies cannot be reduced to better family planning or safer sex. What the black church and black community need is the power of the gospel first and foremost, because only the gospel can pull down the sexual

\footnotetext{
${ }^{26}$ John Freeman, Hide or Seek: When Men Get Real with God about Sex (Greensboro, NC: New Growth, 2014), 31.

${ }^{27}$ Blackburn, "Sex and Fullness," 111.

${ }^{28}$ Freeman, Hide or Seek, 33.
} 
idols of men's hearts and enthrone Jesus Christ there as Lord and King. This means that the black church must get back to its core mission to preach the gospel and make disciples. That is the only real cure for the sexual looseness (and other self-inflicted problems) that pervade the black community.

\section{Child-bearing}

The sexual revolution in America ushered in the practice of severing sex from marriage and childbearing. Eventually, abortion became the main remedy for the millions of unintended and unwanted pregnancies that ensued. As Blackburn explains, "while abortion is not, strictly speaking, a contraceptive, it is still very much the fruit of a contraceptive mentality that divorces sex from pregnancy, and it is a necessary component in a society committed to sex apart from childbearing. And, with roughly 1.2 million babies aborted annually, abortion is clearly not rare, but is rather a devastatingly common method of birth control. ${ }^{29}$ This is particularly true in the black community, where one out of every two pregnancies ends in abortion.

Unfortunately, by separating sex from child-bearing our culture promotes the practice of planning children around life. In other words, if the sexual act produces an unplanned child, the mother can dispose of it if it conflicts with her lifestyle. But the command given to the first couple "to be fruitful and multiply" (Gen 1:26) suggests that couples are to plan life around children. ${ }^{30}$ Sex serves God's purpose to create healthy families, which produce healthy communities and nations. This does not mean that sex is for procreation purposes only. The fact that the female reproductive cycle includes only a brief window in the month for impregnation suggests that sex has other purposes besides procreation (e.g., consummation, commitment, act of love, pleasure, and communication). However, as Dennis Hollinger observes, "any sexual act must be in the context of procreation and be willing to bear the potential fruit from the act." ${ }^{31}$ In other words, the procreative nature of sex means that all parenthood is to be considered "planned" (even when contraceptives fail) and all children are to be treated as "wanted." Understanding sex from this full-blown Christian worldview perspective is critical to building strong black families and communities because it holds together marriage, sex, and childbearing in the order prescribed by God. Indeed, the Bible is perfectly clear that "only within the bounds of matrimony will intercourse 'produce a stable society."”32

\footnotetext{
${ }^{29}$ Blackburn, "Sex and Fullness," 128.

${ }^{30}$ Ibid., 130.

${ }^{31}$ Dennis P. Hollinger, "The Ethics of Contraception: A Theological Assessment," Fournal of the Evangelical Theological Society 56.4 (2013): 693.

${ }^{32}$ Boys, "State of Black Family."
} 


\section{Conclusion}

The words of Bishop E.W. Jackson probably best summarize the challenges presented in this article: "Only God, prayer, and a good church led by a good pastor can lead people toward chastity, life-long marriage and a stable family. The black church must lead in this area." ${ }^{33}$ Indeed, this is how the black church will win the battle against abortion in the black community.

But if black church leaders persist in supporting abortion, whether through active participation or silent opposition, the warning of Jeremiah 5:29-31 may very well apply to it:

"Shall I not punish them for these things? Declares the LoRD, and shall I not avenge myself on a nation such as this?" An appalling and horrible thing has happened in the land: the prophets prophesy falsely, and the priests rule at their direction; my people love to have it so, but what will you do when the end comes?

Now is the time for black pastors to choose wisely. 


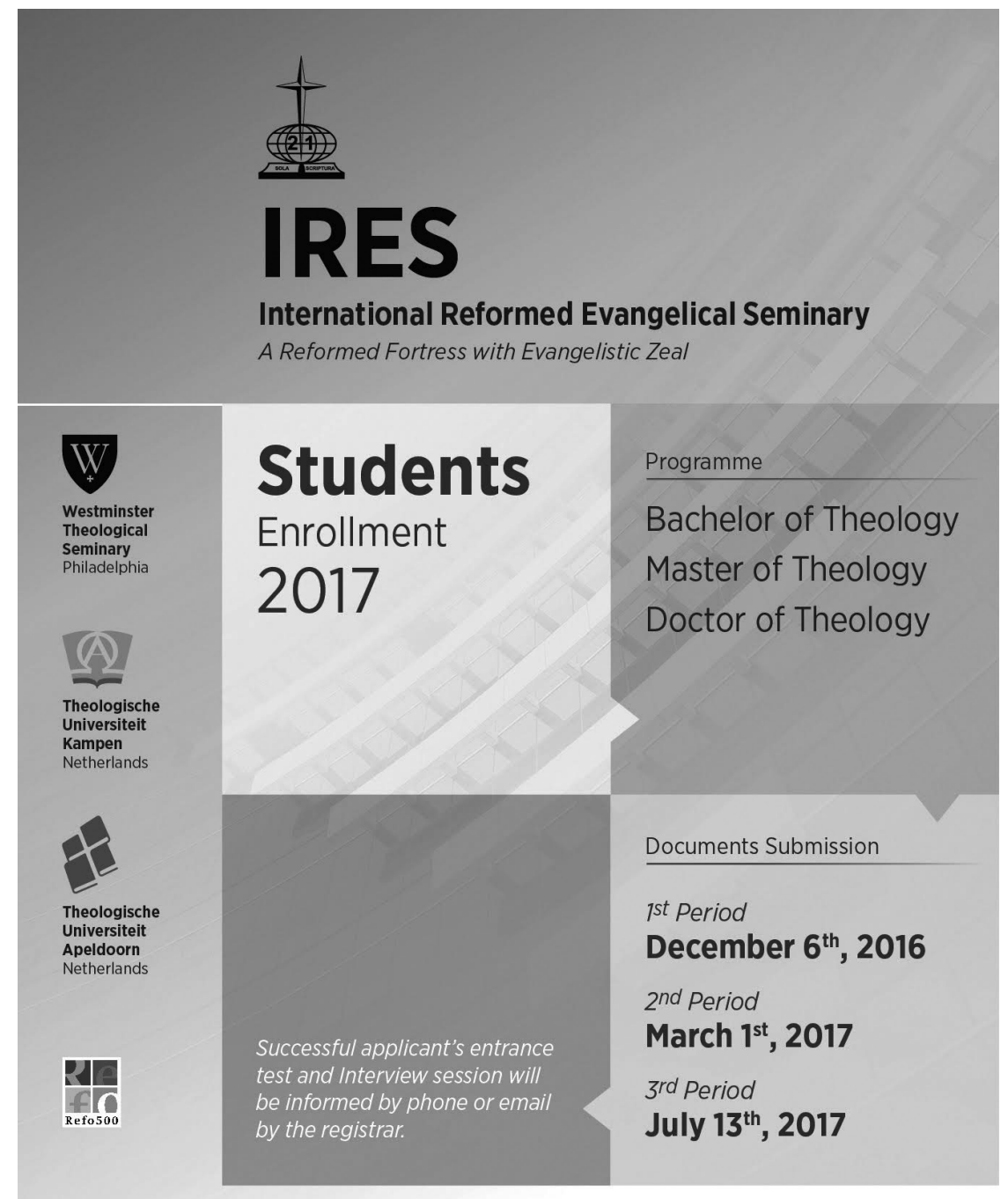

Phone: +6221-6586 7809

Email: admissions@sttrii.ac.id | Website: sttrii.ac.id

Reformed Millennium Center Indonesia

Gedung Kebudayaan Lt. 6

Jl. Industri Blok B 14 Kav. 1

Kemayoran, Jakarta Pusat, 10720, Indonesia.
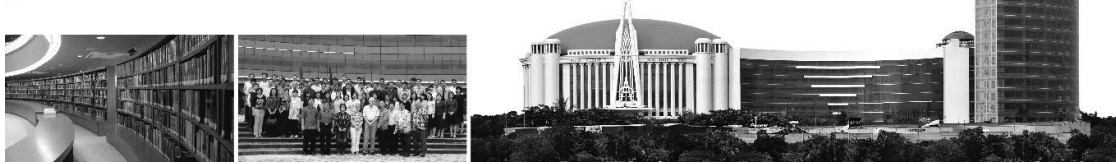


\section{A Review and Evaluation of J. Richard Middleton, A New Heaven and a New Earth}

\section{G. K. BEALE}

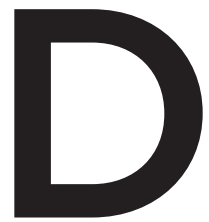

ebates about eschatology have continued unabated in evangelical theology up until the present time. Among those debates is the issue about how much continuity there is between the present earthly age and the eternal age to come. Some see no continuity: when we die we are spiritually raised from a material earth and body to a nonmaterial heaven and body, and remain there forever. Others see a lot of continuity, sometimes so much that the only difference between the two ages is that there will be an ethical cleansing of the old earth, and then an ethically cleansed earth will continue on into eternity, with believers being physically resurrected and residing there. Still others see the continuity/discontinuity residing in a destruction of the present earth and re-creation of its chaotic material into an eternal new heaven and earth. Other views that are variants of these three could also be mentioned. Richard Middleton has written his book to address these issues and to give what he believes is a biblical perspective on these thorny matters. He says the purpose of his book is to "sketch the coherent biblical theology

1 A review of J. Richard Middleton, A New Heaven and a New Earth: Reclaiming Biblical Eschatology (Grand Rapids: Baker Academic, 2014), pp. 332. This review was first read at the Biblical Theology Section at the annual meeting of the Evangelical Theological Society in 2015 in Atlanta, Georgia. Some revision has been done since then. 
... that culminates in the New Testament's explicit eschatological vision of the redemption of creation" (p. 15).

The outline of the book is as follows: Chapter 1 lays out the problem of the purported traditional Christian view of "heaven," which does not include a transformed earth as the final destiny of believers. Chapter 2 presents God's original intent for humans in God's image to inherit a transformed new earth (primarily involving cultural development and care for the environment). This divine intent was blocked by sin. Chapter 3 sketches the broad sweep of the biblical story, wherein God's purpose is to redeem earthly creation (rather than take us from earth to heaven). Chapters 4-5 address the holistic view of salvation in the Old Testament (esp. in Exodus and the Old Testament law, wisdom, and prophecy), particularly God's commitment to the flourishing of life in a concrete, physical, and societal earthly environment (i.e., the concerns of wisdom include speech, sexuality, family, work, debts, food, disease, wealth, and political governance [cf. p. 98]). Chapter 6 surveys typical Old Testament passages predicting the destruction of the cosmos and finds that all the descriptions are figurative in the sense that a complete and absolute annihilation of the earth is never envisioned. This means that God will redeem the old earth and transform it into a new earth. Chapter 7 discusses the inextricable link between resurrection and rule accomplished by Christ and to be expressed through all who are identified with his resurrection and rule. Chapter 8 focuses on the New Testament notion that sin and evil will be reversed, so that salvation includes not only moral redemption and transformation of people but also physical transformation and renewal of people and of the physical earth. Chapter 9 analyzes New Testament texts that typically are misunderstood to teach the annihilation of the cosmos, leaving room only for a "heavenly" nonearthly eternal salvific destination. Chapter 10 explores various texts that some wrongly contend show that a nonmaterialistic "heaven" is the central destination of saints. This also entails that there will be no "pretribulational rapture" of saints being with Christ in heaven until Christ's final coming and that there will be no intermediate spiritual state in heaven before the final transformation of the cosmos. Chapter 11 contends that the essence of Jesus's teaching on the kingdom is to be found in Luke 4, where Jesus says that the "good news" is primarily about renewal of the entire person and of the social order. Chapter 12 concludes with the ethical challenge presented by Jesus's "manifesto" in Luke 4, by which people are confronted with a "vision of the kingdom of God that is both applicable to every dimension of earthly life and open to the entire human family" (p. 282). There is an appendix that attempts to survey how an eternal heavenly and 
nonearthly destiny came to dominate popular Christian eschatology. Included here are also those who throughout church history and especially recently have focused on the actual renewal of an everlasting earth wherein physically resurrected believers will live.

There are several strengths of the book. First, spot on is his holistic view of redemption, which culminates in physically resurrected believers living in a transformed newly created eternal heavens and earth. This is the main point of the book and its strength. This is his well-repeated point and apologetic against the popular notion that a non-earthly "heaven" is the eternal salvific destination of saints. He well substantiates his point that there is not a single reference to the righteous living in an eternal nonmaterial heaven as their final destination (e.g., pp. 72-73). His exegesis of various debated texts with respect to this issue is generally good.

His sevenfold summary of what will happen when Israel is restored from exile (according to OT prophetic visions) is excellent, including both spiritual and physical dimensions of that restoration (pp. 105-7): 1) return to the land; 2) restoration and healing of God's people in society; 3) flourishing of the natural world, including peace among animals; 4) new relationship to the nations, centered in Zion; 5) forgiveness of sin and new heart, enabling God's people to keep Torah; 6) restoration of righteous leadership for Israel; and 7) God's presence among his people in the renewed land.

The discussion of the image of God, based primarily on his earlier book, The Liberating Image (2005), is very good, including emphasis on a functional view of the image (pp. 39-55). Adam is God's priest and image placed in the sanctuary in Eden. The image is reflective of God, and it reflects God out to others like a prism. Adam's task was to subdue and rule as God's viceroy and fill the earth with God's presence, thus expanding the sanctuary of Eden to cover the whole earth, a theme that I also discussed in my 2004 book, The Temple and the Church's Mission. ${ }^{2}$ God's presence is especially spread through farming and culture building (which presupposes faithfulness to God and his word, and which needed to be discussed more by Middleton). I had never considered Middleton's excellent observation that God's activity of planting a garden was to be imaged by Adam and his progeny's similar activity, which expresses that culture building is an aspect of reflecting the divine image. There is no "sacred-secular" split in the fulfilling of Adam's commission, which is passed down to others and finally achieved in Christ and his people. All of reality, both spiritual and

2 G. K. Beale, The Temple and the Church's Mission, New Studies in Biblical Theology 17 (Downers Grove, IL: InterVarsity Press, 2004). 
physical, immaterial and material, is to be subdued and ruled over. All this is very good.

Middleton traces the storyline of Scripture well. When Adam disobeyed the mandate to reflect the divine image, his commission devolved onto the patriarchs and Israel, and when they disobeyed, Jesus finally fulfilled it and his people fulfilled it by faith in identifying with him (chapter 3). Just as Adam was to build and widen the temple of Eden by reflecting God's presence, so was Israel and Jesus, the latter finally accomplishing this mission (see pp. 166-68). The fulfillment of the entire cosmos becoming one huge temple is presented in Revelation 21:1-22:4, where, for example, the whole cosmos is portrayed as the holy of holies (pp. 168-71), a major point for which I have also argued throughout The Temple and the Church's Mission. This is a very good tracing of one of the major plot lines of Scripture.

The book also rightly recognizes an "already and not yet" eschatological outlook of Scripture.

As always with any book, there are some quibbles that I have with parts of this book. First, the reason for writing the book is the author's belief that a vast swath of Christians, though believing in a final resurrection body, view the final, eternal destiny of believers to be in a nonmaterial heaven. Some well-known hymns are adduced in support. Middleton cites Origen as an early church father who believed that the eternal destiny of Christians is in a nonmaterial heavenly dimension. Middleton surveys some of the second, third, and fourth century premillennialists (or temporary millennialists) as examples of authors that were unclear about whether or not they supported the final destiny of saints being in a nonmaterial heavenly sphere (pp. 284-90). Middleton says that this early premillennialism testifies to the ongoing biblical witness of a form of this-worldly redemption (p. 291). He appeals to Augustine as the first major figure since Origen to hold that the final destiny of the righteous is in an acosmic and atemporal sphere (pp. 291-93). In the medieval period, Augustine's view dominated, though there was some continuation of premillennial belief (pp. 293-95). While Calvin and Luther gave lip service to a renewed eternal earth, they also inconsistently referred to "heaven" as the eternal state (pp. 295-96). This survey of the medieval and Reformation periods is too brief and leaves much to be desired. Middleton notes that from the Reformation to the modern period, emphasis on heaven as the eternal state continued, with some exceptions being John Wesley, Ellen White, and the Stone-Campbell movement (pp. 297-99).

Thus, Middleton sees a belief in an eternal immaterial heaven dominating Christendom from the time of Augustine up to around some point in 
the mid-twentieth century. I think it would be a dissertation topic to investigate this issue in any of the above authors, so I think Middleton's conclusion ought to have registered much more reserve about his brief survey. For example, Augustine does give some testimony to a renewed physical earth in which believers live:

Wherefore it may very well be, and it is thoroughly credible, that we shall in the future world see the material forms of the new heavens and the new earth in such a way that we shall most distinctly recognize God everywhere present and governing all things, material as well as spiritual. ${ }^{3}$

Beginning with the late nineteenth and early twentieth centuries, scholars from different theological traditions began to express belief in an eternal new earth (pp. 303-12). Despite the ongoing popular belief in an eternal heaven as the ultimate destiny of believers, these other scholarly voices indicate that we are in the midst of a paradigm shift toward affirmation of belief in an eternal material earth.

He says the "time is ripe" to forge a robust vision for a renewed eternal earth wherein live resurrected believers, and Middleton hopes his book will cast such a vision.

But another problem with Middleton's historical survey is that dispensational premillennialism, which has dominated twentieth and probably even twenty-first century popular Christian belief, has always believed in an eternally renewed earth after the millennium and destruction of the first heavens and earth. Such belief may not have produced the motivation for the kind of Christian cultural activity that Middleton urges, but it has still maintained a solid belief in a final physical cosmos, for which Middleton also is mainly arguing. (Middleton acknowledges this to some degree in passing, but sees it as a de-emphasis [p. 301].) There was thus much more belief in the twentieth century supporting a renewed physical earth than Middleton acknowledges. It is especially classic dispensationalism's emphasis on a pretribulation rapture to which Middleton negatively reacts. $\mathrm{He}$ sees this doctrine as unfortunate, since he believes it "contributes to the otherworldly, escapist attitude" (p. 301) and leads to a "lack of concern for our earthly future" in the eternal new cosmos (p. 303). Accordingly, this is not good because it blunts motivation for Christians to involve themselves in affecting the culture of the present world (pp. 300-301).

Nevertheless, Middleton is probably right that there are a substantial number of Christians, especially among laypeople (and, I would add, above

3 Augustine, The City of God 22.29 (NPNF 1 2:509, my italics). 
all, nominal Christians), who think the only destiny after death is a nonmaterial spiritual existence in a nonmaterial eternal heaven.

Another issue is that Middleton reacts against a view that emphasizes eternal spiritual salvation over a notion of eternal salvation that affects soul, body, and the physical world. But he reacts so much that there is a de-emphasis on the spiritual facet of salvation. Page 79 is the only place where he comes close to having any significant discussion of spiritual "salvation," and that discussion takes up only half a page. Included in that discussion is "justification," which he briefly defines as "being made right with God through forgiveness of sins," and as "a beginning of a right relationship with God through deliverance from the penalty of sin (anticipating that we will stand with confidence before God in the final judgment)." ${ }^{4} \mathrm{He}$ then says, "Although this [view of spiritual salvation] is certainly an important part of salvation, it is limited by both its individual focus and its fixation on the notion of deliverance." Such a spiritual view for Middleton is too limiting, since "salvation" comprehends present and future and "affects every aspect of existence." He then concludes that "the most fundamental meaning of salvation in Scripture is twofold: it is God's deliverance of those in a situation of need from that which impedes their well-being, resulting in their restoration to wholeness ... Both ... are crucial to salvation" (he says the same thing in abbreviated form on p. 269, n. 7). Likewise, a little later he says, "Salvation cannot be limited to deliverance from external circumstances; it must include what we might call 'sanctification"' (p. 88). On page 83 Middleton says that Christ's death and resurrection have defeated powers hostile to God and defeated death itself.

Thus, as far as I have been able to tell, he briefly discusses individual spiritual salvation on only about four pages out of 312 pages, and even some of these discussions are abstract or unclear.

The very heart of Middleton's argument is that Scripture affirms a physically transformed eternal new earth toward which we should ever look. This is a wonderful truth and strength of the book, as I mentioned earlier. However, there is some significant ambiguity here. He well shows that many Old and New Testament prophecies of the destruction of the world are figurative to one degree or another to indicate "transformation" and not to be understood as a literal "annihilation" of the old cosmos "but rather a new world cleansed of evil ... extreme language is often used to emphasize the radical nature of the purging required for salvation" (p. 125). The discussion of 2 Peter 3 is a good place to focus on this question (pp. 189-200).

4 He also mentions "forgiveness of sins and a new heart" on p. 106. 
Middleton concurs with a view that the destruction pictured there is both figurative of destroying demonic powers and literal of destroying part of the upper layer of the cosmos. Furthermore, Middleton concurs also with a view that the "melting" in 2 Peter 3 has a metallurgical smelting background, so that the picture there is "ultimately cleansing and not destructive." He says that this cleansing is like the cleansing of Noah's flood, which Peter has compared with the coming fire and melting.

But what kind of "transformation" is this? Middleton says it is not "annihilation" or "obliteration," but he says it is really only unbelievers who will be destroyed, while "the earth and its human works will be found" (pp. 193-96). Richard Bauckham understands the word "found" (heurethesetai,

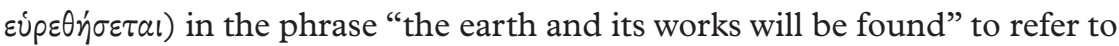
God laying bare the sinful works of sinful people and judging them. This is

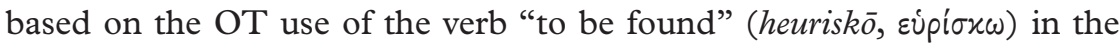
sense of "to be detected" or "to be discovered" as criminals or evil doers (e.g., Exod 22:8; Deut 22:22, 28; Jer 50:24 [= LXX 27:24]; Ezra 10:18). ${ }^{5}$ Thus, according to Bauckham's view, sinners at the end of time will not be able to hide themselves or their sins from the gaze of God the Judge.

Middleton believes that it is viable to see 2 Peter 3:8-10 in light of the image of a smelting process, whereby the dross is removed from gold or silver, with only the gold and silver remaining. This would make what is "found" positive, so that the "works" are positive and remain on into the new creation. But even so, this smelting image could be generally metaphorical or literal for a radical transformation from the old earth to that of the new. The smelting image here would be supported by 1 Peter 1:7: "that the genuineness of your faith, being more precious than gold which is perishable, even thought tested by fire, may be found to result in praise and glory and honor at the revelation of Jesus Christ." Middleton is dependent here on an article by Al Wolters, ${ }^{6}$ who concludes that in contrast to "the present created order as expendable in the overall scheme of things," "our interpretation ... stresses ... the permanence of the created earth, despite the coming judgment." ${ }^{77}$ On balance, Wolters's view that a smelting picture is in mind may be preferable to that of Bauckham. But does such a smelting picture demand the notion of "the permanence of the created earth, despite the coming judgment"? And, we can ask, what is meant by "the permanence of the created earth"? Some have seen 2 Peter's language here to indicate an

5 Richard J. Bauckham, 2 Peter, fude, WBC 50 (Waco, TX:Word, 1983), 319.

6 Al Wolters, "Worldview and Textual Criticism in 2 Peter 3:10," Westminster Theological Fournal 49 (1987): 405-13.

7 Ibid., 413. 
ethical cleansing that does not destroy the earth or the cultural works of believers living on the old earth but renews the earth ethically, leaving its material basically intact (on analogy with the pre- and post-flood world). Others have seen the transformation to be a literal material destruction (not annihilation) of the earth and a re-creation of a new earth from the chaos of the old destroyed earth. To which does Middleton hold? I am not sure. He mentions the latter view (p. 197, n. 38), but he does not commit himself to it. It seems that Middleton leans toward the former, as Wolters clearly does, especially in the light of his conclusion about 2 Peter 3:

Taking all the complex layers of meaning in 2 Peter 3 together, we find a picture of radical judgment on the last day, in which God destroys corrupt demonic powers, metaphorically strips back the sky, then comes to judge the earth - a judgment intended to purge the world of evil so that it might be renewed, and ultimately, saved. This means that whatever vivid language of destruction Peter uses to portray the final judgment, there is no good reason to take any of it as referring to the literal obliteration of the cosmos. (p. 196, my italics)

Some sort of clarification was needed here on the nature of the cosmic transformation. Does "obliteration" mean that nothing at all will be left of the first creation, or does it mean that the "obliteration" reduces the earth to chaotic material, from which a new creation is made? It appears that he holds to some version of the former view. Accordingly, he appears to view the new creation as something at least comparable to the material earth left after Noah's flood. He appears to see that the earth itself will not be reduced to rubble but will undergo only some kind of ethical cleansing and continue on eternally as the same material, but ethically renewed, earth. The gist of Middleton's work seems to point to godly humanity's culture building being carried over into the new creation. ${ }^{8}$

One important reason that there needs to be clarity on the precise nature of the transformation is that it underlies the ethical motivation issue. For example, some postmillennialists in the past have said there will be no significant material transformation at the end but only an ethical cleansing. Therefore, the godly cultural progress made throughout the church age will also be carried over into the new eternal eschatological age. This gives much motivation to believers to build culturally in this age, since their efforts will be rewarded by having such cultural efforts carried right over into the new age. I am under the impression that Middleton's motivation fits into a paradigm comparable to this. Indeed, that this is Middleton's

\footnotetext{
8 A similar need for clarification on this issue is mentioned by another reviewer (J. P. Davies,
} Review of Biblical Literature [08/2016]). 
position is apparent in his "Appendix," where he states that a significant segment of classical dispensationalists

affirmed the idea of a replacement of heaven and earth after the annihilation of the present cosmos (citing 2 Pet. 3:10 and Rev. 21) without any awareness of possible implications for holistic living in the present. (p. 301)

However, if the old earth is to be destroyed literally and is to be re-created from its own chaos (which is my own position), then such cultural efforts by the godly will not be carried over concretely into the new eternal earth. In this case, what is the motivation for affecting culture for Christ? Is Middleton correct is saying that such a view provides little ground for motivation to involve oneself in godly culture building? I will address this issue in a concluding excursus, since the focus of this review is on Middleton's positions.

Middleton also addresses the issue of how to define the "gospel" in the light of Luke. "Proclamation of the gospel" for Middleton entails the following: "communicating the teachings of Jesus about the nature of the kingdom, and especially what God has done in the life, death, and resurrection of the Messiah" (p. 69). When he explains what is the content of the gospel, he focuses on Luke 4:18-19, where Jesus quotes Isaiah 61:1-2 as what Middleton calls the "manifesto" of Jesus's mission (pp. 249-82). The crucial phrases cited in Luke 4 are all taken to refer to "the concrete, this-worldly nature of the salvation proclaimed" by Jesus (p. 253): “(1) to bring good news to the poor, (2) to proclaim release to the captives (3) and recovery of sight to the blind, (4) to let the oppressed go free, (5) to proclaim the favorable year of the Lord." Middleton says, "We need to take seriously that he [Jesus] literally meant to include those who were economically impoverished and politically marginalized in first-century Israel" (p. 261). He concludes: "God's kingdom impacts the entirety of our lives - our bodies, our work, our families, all our social relationships, even our relationship to the earth itself" (p. 262).

But where is any mention by Middleton of the spiritual healing that Jesus came to bring? He says "this holistic vision [in Luke 4] is a powerful antidote to our narrow, constricted understandings of salvation." But does not Middleton's view do the opposite by, at least, greatly underemphasizing the spiritual forgiveness of sins? It is telling, for example, that in his explanation of Isaiah in relation to the New Testament he says virtually nothing about the forgiveness of sins brought by the suffering servant in Isaiah 53. Among four references in the index to Isaiah 53, only one possibly touches on the mission of the servant there: "the Suffering Servant's ... humiliation (and even death) will accomplish salvation for others (see esp. 53:4-6, 10-12)" (p. 85). But even here he does not describe what "salvation" is or "how" the 
servant brings salvation. He says that Luke 4 has been overly "spiritualized" by others, but he seems to take it too far in the other direction by "physicalizing" it (p. 267). The problem with constricting Christ's salvation to the physical sphere is that this is not a "holistic" view of Christ's redemption, which is both physical and spiritual. At the least, Middleton should have made some significant mention of the spiritual dimension of Christ's redemption in order to present a holistic view of it.

In fact, if one examines the broader context of Luke, the word "release" (aphesis, ă $\varphi \varepsilon \sigma \varsigma$ ) found in Luke 4, alluding to some degree to the Levitical proclamation of the Jubilee Year (Lev 25:10), "is used exclusively in reference to those who are captive to $\sin$ as a release, or to forgiveness, from that state of captivity (Luke 1:77; 3:3; 7:47; 24:47; Acts 2:38; 5:31; 10:43; 13:38; 26:18)." "Thus, "release" is not only release from physical bondage; rather, Luke stresses even more "release" from spiritual bondage.

Such is also the case with Jesus's reference to "recovery of sight to the blind" in Luke 4. It refers both to recovery of literal sight (so Luke 7:21-22; 18:35-43) and also recovery of spiritual sight (Luke 6:39; 8:10; 10:23-24). Both should be highlighted, though the inaugurated era focuses more on the spiritual.

Thus, both physical and spiritual healing are in mind in Luke 4:18-19. The redemptive-historical rationale that includes both is that Jesus has come to inaugurate the new creation, which reverses both the spiritual and physical curses brought with Adam's primal sin. Middleton does not discuss much at all the problem of human sin and its spiritual ramifications (an observation made by Dane Ortland at the Biblical Theology session where Middleton's book was reviewed). Could this be part of the reason he does not highlight the spiritual release from $\sin$ in the redemption wrought by Christ at the cross, who paid the penalty for this sin?

Indeed, Jesus's first coming begins to fulfill all the various OT prophecies spiritually, and at his final coming these prophecies are consummately fulfilled both spiritually and physically, as stated in 2 Corinthians 1:20 and particularly John 5. This two-stage fulfillment, the latter of which shows the prophesied resurrection of Daniel 12:2, is spiritual in Jesus's first coming and physical at the very end of the age. All the various prophecies follow this two-stage process. The two-stage fulfillment of the Year of Jubilee is another example of such a two-stage fulfillment. This is what I tried to

9 See Daniel M. Gurtner, "Luke's Isaianic Jubilee," in From Creation to Nerw Creation: Biblical Theology and Exegesis, ed. Daniel M. Gurtner and Benjamin L. Gladd (Peabody: Hendrickson, 2013), 140. Acts 13:38 and 26:18 are respectively direct allusions to Isaiah 49:6 and $42: 7,16$. 
develop throughout my New Testament Biblical Theology. ${ }^{10}$ By the way, as noted above, this does not mean that in the first stage there is no relation of fulfillment to physical and societal realities; rather, the focus of fulfillment is not in that sphere. However, those experiencing spiritual renovation should affect societal and physical realities and institutions as a witness to their faith, as well as the motivation of beginning to behave now in the way they will consummately behave in the eternal new creation, which includes being stewards of that physical creation.

Middleton is opposed to too much talk of immaterial, spiritual notions of salvation because he appears to think they might divert attention from the coming material new creation. In this respect, he argues against any notion of an intermediate heavenly and immaterial state where believers dwell consciously with God and Christ (pp. 227-37). ${ }^{11} \mathrm{He}$ cites typical references adduced to support such a belief and proceeds to refute each one. It is not my purpose to attempt here to argue against Middleton, but it would have been useful if he had addressed the work of Anthony A. Hoekema, who has a significant chapter on this subject in his The Bible and the Future. ${ }^{12}$ Likewise, his contention that Revelation 6:9-10 does not refer to conscious believers appealing to God in heaven because it is "imaginative apocalyptic symbolism" is not a sufficient argument. ${ }^{13}$

It is interesting that Middleton (who has been influenced to some degree by a Reformed Kuyperian background, though he presently teaches at a Wesleyan $\operatorname{school}^{14}$ ), refers to the ultimate goal of Scripture's plot line as being the full establishment of God's presence (or "glorious presence," which he mentions three times in the book). That is, his special revelatory presence will be finally spread throughout the earth, which has become the cosmic holy of holies. But, according to especially a Reformed framework,

10 There I have 70 pages toward the end of the book highlighting the inaugurated and then consummated fulfillment of OT prophecies with respect to the importance of both the spiritual and physical dimensions. G. K. Beale, A New Testament Biblical Theology: The Unfolding of the Old Testament in the New (Grand Rapids: Baker Academic, 2011), 887-957.

11 Of course, most who hold this position believe that Christ is present in the heavenly dimension in his resurrected and exalted body.

12 Anthony A. Hoekema, The Bible and the Future (Grand Rapids: Eerdmans, 1979), 92-108.

13 See further on Rev 6:9-11, G. K. Beale, The Book of Revelation, NICNT (Grand Rapids: Eerdmans, 1999), 390-95, where the overall argument points best to a conscious existence of saints in an intermediate state. Likewise, a classic amillennial reading of Rev 20:4-6 envisions a conscious existence of saints during the interadvent age (ibid., 995-1021).

14 His reference to "freedom" of "our will" on p. 207 would appear to reflect a Wesleyan perspective. Middleton is an adjunct professor at Roberts Wesleyan College and is a full faculty member at Northeastern Seminary, an "Approved Seminary of the Wesleyan Church International." 
this is a penultimate goal. Is not the ultimate goal of humanity giving glory or honor to God for his magnificent consummated end-time presence? Middleton, as far as I can tell, never speaks of that notion in the book..$^{15}$

Despite my above caveats, which have been the substance of this essay, I do not want to forget the important strengths of the book noted earlier. I learned a lot from the book, and it provides an important corrective to overly spiritualizing views of consummative eschatology.

\section{Excursus: The Motivation for Culture Building Even If the Earth Is to Be Destroyed}

Middleton, as I argued above, appears to root motivation for cultural activity during the present age in the hope that there will not be a catastrophic eschatological destruction of the physical earth. So, the question arises, is there a basis for motivation for godly culture building if one believes in a final catastrophic earthly destruction that results in chaotic material (like the chaos of Genesis 1:2), out of which the new creation is made? My answer is yes. I believe that there is a basis for motivation by Christians to involve themselves with culture on this earth to affect it positively.

My own motivation for cultural development and ecological care arises out of the fact that believers presently participate in the inaugurated eschatological new creational rule. This eschatological rule will be consummated in the earthly new creation. Therefore, the believers' pattern of behavior on the present earth is connected with and should be an anticipation of their consummated perfect behavior in the new earth. Since part of our consummated task in the new cosmos will be to be king-priest stewards of the new earthly creation, our present task as believers should include being a beginning steward of this creation, even if it is to be destroyed (though not annihilated). Since we should be stewards in the consummated image of God in the final new creation, should we now not be such stewards, since we are in his inaugurated renewed image? In support of this later point is Middleton's outstanding observation that God's activity of planting a garden in Eden was to be reflected by Adam and his progeny's similar activity, which expresses that stewardship of the creation is an important facet of reflecting the divine image. What Adam did in the first Garden is to be replicated on an escalated scale in the final Garden, and that replication commences even in this age.

15 A point observed by another reviewer, Chris Beetham, in Themelios 40.2 (2015): 317-19. 
A good illustration of the kind of stewardship over creation that we are to begin to have now is to be seen in the attitude and care that we are to have toward our own body, which is a part of the old creation. Paul alludes to this in 1 Corinthians 6:13-20. Our old bodies will be done away with at the final resurrection of the saints (vv. 13-14). But believers are to remember that their bodies "are members of Christ" and "they are one spirit with him," so that they should not become "members of a harlot" (vv. 15-17). On this basis, believers should "flee immorality," since "the one who practices immorality sins against his own body" (v. 18). Furthermore, believers should flee immorality because their "body is a temple of the Holy Spirit" and "you are not your own" (v. 19). Because of this and because "you have been bought with a price, therefore glorify God in your body" (v. 20).

Thus, though we still live in old bodies, we are to care for them and do nothing to hurt them. We should be good stewards of our decaying physical bodies. This is because we are even in the present time part of the eschatological temple of the Spirit, the consummation of which is in the renewed eternal earth. If we are so to treat our own body with care now-though it will be destroyed - should we not similarly care for the old earth — though it too will be destroyed? Part of the basis for such care of both our bodies and the earth now lies in that there is continuity between our present bodily existence and our future transformed consummated bodily existence on the new earth; and there is continuity between the old earth's existence and its consummated transformed existence into the new earth. 


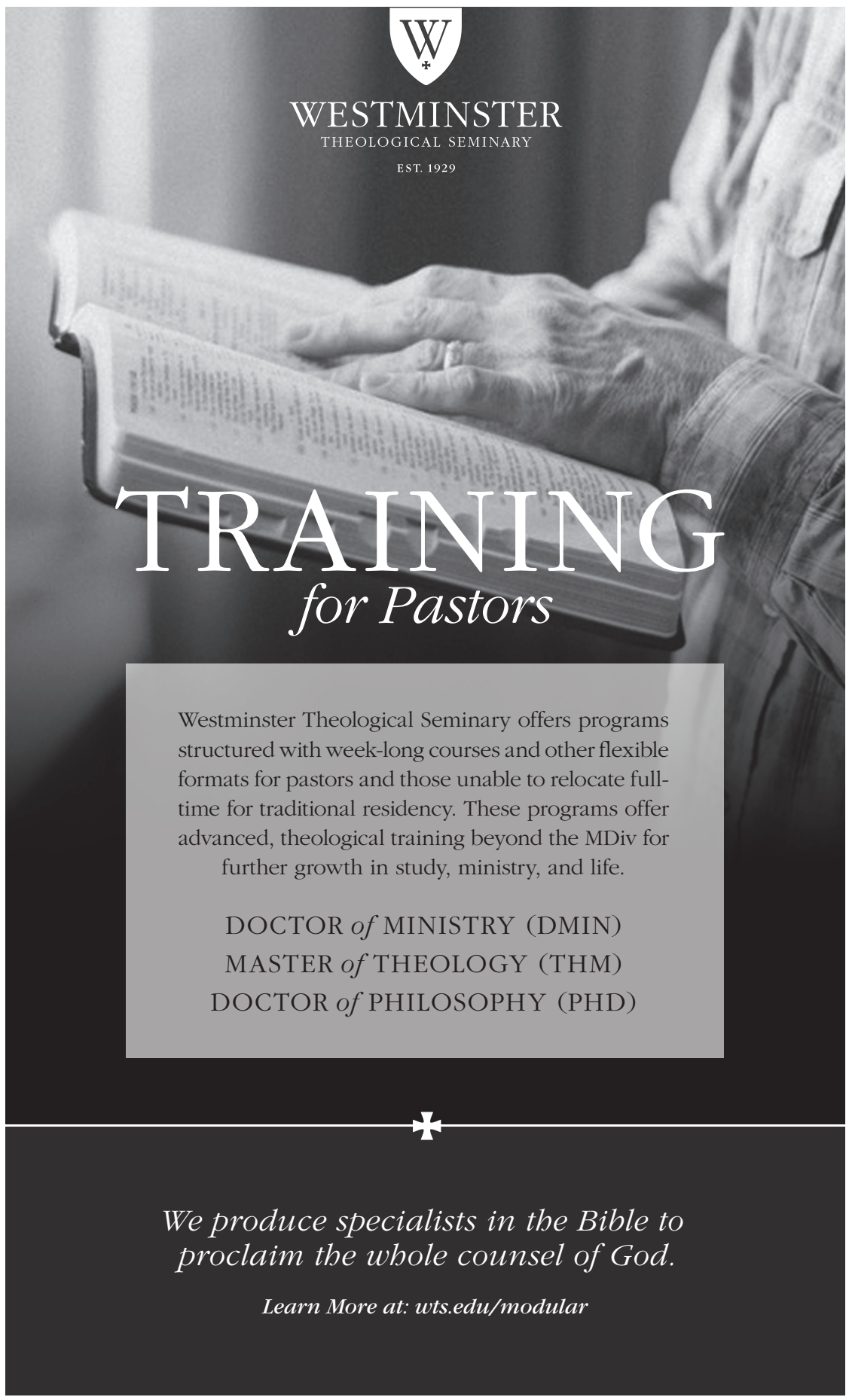




\section{INTERVIEW}

\section{Interview with Dr. William Edgar}

\section{PETER A. LILLBACK}

\section{(December 22, 2016)}

PETER LILLBACK: It's our great privilege to interview professor extraordinaire of Westminster Seminary, Dr. William Edgar. I'll ask him about his coming to faith and connection with renowned apologist Francis Schaeffer, about his work with the Fohn Calvin Seminary at Aix-en-Provence, France, and finally about the recent publication of his book on culture Created and Creating. ${ }^{1}$ Tell us firstly how you got to know Schaeffer and how that impacted your early life.

WILLIAM EDGAR: It's an unusual story. I was a sophomore at Harvard University, an agnostic toying with atheism, but I had a professor at the college who spoke about the Christian worldview. I was quite drawn to this. His name was Harold O. J. Brown. He's now in heaven, but he and I became friends, and he talked about the Christian faith, and I was intellectually quite persuaded, but wasn't a believer yet. I was going back to Switzerland in the summer of my sophomore year with my brother to do a bicycle trip. Harold wrote on a piece of paper, "Francis A. Schaeffer" and a telephone number and said, "If you get a chance you might look him up. This guy is a friend of mine and an Evangelical Christian, like me." That's the term he used.

Halfway through the summer, my brother wanted to go home, and I called Schaeffer from Zurich. Mrs. Schaeffer answered the phone, was very warm, and invited me to come for the weekend. I thought, "This is amazing"; I went down there and found out why: it was a Christian community where

1 William Edgar, Created and Creating: A Biblical Theology of Culture (Downers Grove, IL: IVP Academic, 2017). 
the main teacher, Francis Schaeffer, would give seminars, hold discussion groups, and preach in the church.

PL: How many people and who were there when you showed up?

WE: Probably twenty-five. A good number of them were nonbelievers. There were one or two Christians who were struggling. That first night we had a discussion group where Schaeffer answered all kinds of questions. I remember one was about prayer, and I hadn't thought about this. I had said some prayers because my parents sent me to an Episcopal boarding school, but I'd never prayed to God. I wasn't sure there was a God, and it was a riveting discussion on the way God answers prayer, and if he's not there, prayer is futile. I'd never heard anything like this. So then, the next morning he had time to talk to me, and we spent about an hour and a half together. During that conversation I just knew it was true and I felt my heart change.

\section{PL: Did he share biblical texts with you about the gospel?}

WE: My main question was, "Even if Christianity is true, why is it relevant?" He gave about a forty-five-minute answer using what we call the free will argument for the problem of evil. It's an argument I've come to struggle with, as I think bits of it are true and bits are not. Doesn't matter. It was mightily used of God, and at the end of this conversation he said, "Why don't we pray together?" I said, "That sounds fine." He said, "Well, you start." "What do I say?" And he said, "Well, why don't you start off thanking the Lord for what he has just shown you?" So, tears streaming, I mumbled some sort of prayer, and then he finished.

And then I asked him if I could stay for awhile. And he said, "Well, we're very, very busy ..." Little did he know that very busy in the 1970 s would be 130 ! But they found room for me, and I stayed the rest of the summer and took part in the life. Our meals were shared with Dr. Schaeffer, then after, we used to walk down a road to Panex. Most questions we didn't want to ask in front of everybody we could ask in private, and he would answer them. He was just a remarkable resource.

PL: Is that when you met Os Guinness as well? You dedicated your recent book to his honor.

WE: Yes, I met him the next year in Boston when he was traveling with Dr. Schaeffer. He came to Park Street Church when I was still a student at Harvard and gave some speeches; and he was really the heir apparent, I think, in those days. We've been very fast friends ever since. 
PL: If you look back at those moments and the influence of Schaeffer on your life through his personality, friendship, and teaching, what would you say was his greatest contribution to the apologetic world and to you?

WE: He was not only vitally important for the content of what he taught, but he modeled the way to speak the historic Christian position into the twentieth century. So even today, in conversations with people, with unbelievers, I often hear Schaeffer's voice in my head and think, "What would he say?" Then I try to be as wise as he, and so his influence on me is really monumental.

When I completed my final year at Harvard, I decided to go to seminary, and along with seven or eight of us from my class, decided to come here to Westminster. We'd been influenced by Edmund Clowney, who'd been up in Cambridge and spoken. We thought, "We want to be where this man is." When I came here, I studied under Cornelius Van Til, and he was the second monumental influence on me. How were Schaeffer and Van Til different? Put it this way: on all the fine points, doctrinal issues, and apologetic methodology, I would be a Van Tillian. He differed with Schaeffer on various issues, and I would have to agree with the way he criticized Schaeffer. On the other hand, Schaeffer was such an enormous personality and a gracious evangelist, and he had given his life sacrificially to spread the gospel to whoever went to L'Abri. Eventually he made films, wrote books, and in that way I would like to emulate Schaeffer. So I think I got the best of both worlds because these two great warriors started me off in the Christian faith.

PL: That's great! So turning to your ministry, when you left seminary and began to serve, how did the Faculté fean Calvin at Aix-en-Provence become central for your life and career? You spent eleven years serving there.

WE: I grew up in France and Switzerland, and so French is in my blood. After seminary I was a high school teacher teaching French, as we had a child and I had to put bread on the table. They soon moved me into the music department, as I had majored in music at Harvard. The headmaster allowed me to go to graduate school at Columbia in ethnomusicology. We also founded a church in Greenwich, Connecticut, when I was teaching there.

Then a remarkable man named Eugene Boyer came into our lives. He was a dedicated missionary in France, and he and several colleagues in Aixen-Provence had just founded or reopened a little seminary, the Protestant Evangelical Reformed Seminary, nestled in the University of Aix-enProvence. They needed a professor of apologetics who had to be fluent in French and a Van Tillian, and other qualifications that narrowed it down. By French law, they were supposed to find a French guy first, but I don't 
think they looked very hard, so my wife Barbara and I and our two children moved to France in 1979, and I spent eleven years teaching apologetics there.

It's a marvelous and unique work because it's the only historically Reformed Seminary in France. There is a seminary in Vaux-sur-Seine, near Paris, which would be the other Evangelical seminary. It is baptistic. We at Aix were the only historically Reformed seminary, and our mission was to renew the church and to send out church planters to found new churches, first in France, then in other French-speaking countries, Switzerland, Belgium, etc.

PL: So there were Reformed seminaries, but when you say historic Reformed you mean maintaining a historic Calvinistic creed and confession?

WE: Exactly. There were three other seminaries besides these two: one in Paris, one in Montpellier, and one in Strasbourg, but they were pluralistic and liberal. If you were an Evangelical and believed in the doctrines of the Reformation, Aix-en-Provence was basically your only option. And I'm happy to say more than forty years later, it's thriving, and enrollment is robust. I go back at least once a year to teach there and have had the privilege of teaching a French PhD student, Yannick Imbert, who's now the professor of apologetics, so Westminster is a conduit for good things! The professor emeritus of systematics, PaulWells, was trained here at Westminster. There's a warm connection between our two seminaries.

PL: Bill, how has your love for music impacted your ministry from those early years at seminary all the way through Aix? You mention ethnomusicology, so that's a fancy way of saying you're a jazz pianist. How does that all work into your theology and your ministry?

WE: Well, marvelously, music and theology have always gone together. Martin Luther said something like if you can't sing it, it's not worthy of the name theology; and Johann Sebastian Bach was an amateur theologian. I have a special interest in jazz music partly because I love the music and grew up with it, partly because it has an amazing history, being generated by African Americans during slavery and beyond. While I was at L'Abri I met a remarkable teacher who ran the Dutch L'Abri, Hans Rookmaaker; he was a European expert on early American jazz. He gave lectures on the origins of jazz, blues, and spirituals. I love this music and played it and thought, "It is wonderful that I can love it even more as a Christian, for Christian reasons." So I've always tried to wed music into whatever ministry I was doing. Even today I have a jazz band and do concerts where we explain the gospel illustrated with music. I go to ethnomusicological and 
musicological societies and read papers; music has been a very important part of my life.

PL: Does jazz sound different through French ears or American ears, or do we all hear it the same?

WE: I've thought about this a lot and written on it. ${ }^{2}$ The appropriation of jazz in France is a fascinating story. The French were the earliest people to appreciate jazz for its African American aesthetic. They appreciated it more than a lot of white Americans. Early jazz heroes like Louis Armstrong and Sidney Bechet and others found in France a home and much appreciation. So, the French care passionately about jazz. There are even rival jazz clubs that disagree on the canonical list of acceptable jazz. In Paris today there are twenty jazz clubs with the best kind of jazz. When we moved to France, it was no trouble to find jazz lovers and to form a little band and do concerts. Whenever I go back, I try to play with some of these old friends. So the short answer is that the French love jazz; the longer answer is that there are reasons to do with French music, a close affinity of people like Maurice Ravel or others with the principles of jazz. And then French people endured terrible suffering under the Nazis and much else, and so, since jazz emerged out of a people deeply acquainted with suffering, they felt a kinship with that moaning and outcry that comes with jazz. Jazz is a joyful music, but its joy emerges through the valley of the shadow of death.

PL: Okay, so Schaeffer andVan Til and jazz, what's the connection between those three?

WE: Schaeffer actually loved jazz music, and his friendship with Hans Rookmaaker deepened it. Now, I never talked to Van Til about jazz, though I imagine he knew about it. I don't know whether he enjoyed it or listened to it, but the theological connection is that both Schaeffer and Van Til taught a kind of apologetics known by the somewhat awkward name of presuppositionalism. We're trying to change that to covenantal. I don't know if that's much better, but the idea is that apologetics should not be simply proving to others the Christian faith by using bits and pieces evidences out of context, but it should take into account the foundations of unbelief and challenge those at the level of unbelief. And jazz has deep foundations originating in a believing community. The greatest jazz musicians grew up in the church. Jazz owes its beginnings to the history of the spiritual, which

2 For example, "It Don't Mean a Thing If It Ain't Got 'le swingue,"” in It Was Good: Making Music to the Glory of God, ed. Ned Bustard (Baltimore: Square Halo, 2013), 199-217. 
owes its origins to the music of enslaved Africans who cried out to the Lord. So there are deep affinities theologically between this music that's called jazz and those theologies that deal with the problem of evil and with grace, joy, and love. So that makes a wonderful marriage between the kind of apologetics that we teach here and the kind of aesthetic principles that jazz embodies.

PL: It's a great joy for us to talk to you about your recent book, Created and Creating: A Biblical Theology of Culture. Your life has been shaped by many significant influences that make you uniquely qualified to write a book like thisinternational background, mastery of different languages, study at Harvard, musicology, jazz piano work, mission work, cross-cultural living, teaching and research at Westminster. What was the impetus for your writing this book?

WE: Thank you, Peter. Those are very kind words, not deserved. The impetus was there, as ever since I became a Christian I believed in the interface of faith and culture. In the study of this interface, I was most convinced by the tradition of Abraham Kuyper, Francis Schaeffer, Cornelius Van Til, and Klaas Schilder. While I benefited from other traditions, I always wanted to write a book that would defend that approach from a biblical theological standpoint, and I wasn't aware that that had been done. There are other books, such as Albert Wolters' Creation Regained, ${ }^{3}$ but none of them does the kind of biblical theology that I wanted to do.

PL: How does the cultural mandate give direction in building a biblical theology of culture?

WE: Biblical theology is the recognition of the Bible's revelation particularly in view of its historical unfolding and culminating in Jesus Christ. In this book, I defend the ongoing validity of the cultural mandate. The cultural mandate is the term used by Schilder to describe God's first orders; his first commandments to our parents, Adam and Eve, and by implication to the rest of humanity. Culture, as I understand it, is subduing the earth to the glory of God in an unfolding manner that brings more and more of his attributes and his virtues to light so that we can herald them. Despite the fall, God has provided a way for us to continue to obey the cultural mandate. And there are many reiterations of it in the Old and the New Testaments. I pause over many of them in the book, not all of them, because there are too many.

3 Albert M. Wolters, Creation Regained: Biblical Basis for a Reformational Worldview, 2nd ed. (Grand Rapids: Eerdmans, 2005). 
PL: There are other uses of culture than the one you are developing; in fact, some would say the culture's dangerous for the Christian. Your book talks about the negative texts or the contra mundum texts about staying away from the world. How do we put together the positive sense of culture that's developing and the danger of a culture that's antagonistic to God?

WE: Certainly both are true. I love what the Apostle Paul says: "Prove all things." In other words: try them out. "Retain what is good and eschew what is bad" (1Thess 5:21-22). Culture is one of those areas of life we need to try out, some of us by practicing the arts, others, business, law, family life, and so forth. All these aspects of culture need to be proven, and we need to hold onto what is good, which the Word of God outlines for us. It's still good to work, have family, honor the civil magistrate, and then to eschew the evil (and there's plenty of evil in human culture). Christians are meant to be salt and light. Sometimes in Scripture the world is presented positively, as the place God made and loves. Sometimes, it's presented negatively, particularly in places like First John that tell us to avoid worldliness (e.g., 1 John 2:15-17). We have to discern which aspects of culture are for us to enjoy, embrace, and promote, and which are for us to stay away from. Worldliness in John's sense means the temptations to idolatry, to lust, to self-aggrandizement, works of the devil, not the works of the good Lord. So, those warnings are dire. They are not warnings to stay away from all culture, but to stay away from the cancerous, sinful culture that has invaded us.

PL: So there are two concepts: common grace and antithesis, the tension of the Christian with the worldly system. How do those two work out, and who are some of the theologians behind those ideas?

WE: Common grace is a concept that comes out of Scripture, but it was noticed and developed by Calvin and, of course, Kuyper and Van Til. God continues to look with favor on both his elect and nonelect people. And that favor is not despite the fall and the antithesis, but it's in view of the antithesis. He shows he is gracious and patient even to people who are not responding to the gospel. In the end, the antithesis will be fully expressed in the judgment. After that, it won't be possible anymore for unbelievers to exercise their gifts, but as we wait, the wheat and the tares are growing up together, and there's a mixture, as it's not yet the time of judgment. By God's common grace we're to engage in the world alongside unbelievers, fully aware that there is an antithesis. In fact, you couldn't call it grace if there weren't an antithesis. We're in the time of God's patience, and he is calling unbelievers to himself and giving gifts to all kinds of people, whether they be followers of Christ or not. Common grace is an important part of 
the idea of culture for Christians. Culture is one of those areas where God has proffered a great deal of common grace to people who don't believe in him. Medical advances and artistic output and so forth-some of it is quite extraordinary but not produced by believers.

PL: How then would you contrast, say, Marxism, postmodernism, and historic Christianity as ways of interpreting culture?

WE: Karl Marx is a very important voice, perhaps the most influential modern commentator on economics and society. Basically, his view of culture is in terms of class struggle, so it's about power. Revolution when the proletariat rises up against the bourgeoisie who have power over them is inevitable.

PL: So they would destroy music and art and science in the name of that cultural view?

WE: Well, they bring their own. They would not destroy all music and art. Marx had a certain place for music and the arts, as did Hegel, but he was so worried about the confusion of the arts with economic power that he encouraged the proletariat to revolution and the destruction of the entire system. It never quite happened that way, even in Russia. However, Marx taught us there is a power dimension to culture, and that can be a good thing or a dangerous thing. Christians have been slow to see the power dimension.

PL: What is its successor, would you say then?

WE: Globalization, maybe, the increasing interconnectedness of every part of human life. Certainly economic but also communication, transportation, and most importantly the idea that as an interconnected person I have an awareness of the world that preglobalized people didn't have. That gives me the feeling that I'm a global person. Some of that is good; some of it is not good, because we disperse ourselves into what we can do rather than concentrating on what we should do. One of the positive effects of globalized culture is that it has opened up windows to cultures and peoples with whom we wouldn't have had contact. In Washington a couple of weeks ago I went to a seminar on Balinese gamelan music which exhibits beautiful orchestras from Bali; I was enriched by the beauty created by this wonderful music. Negatively, globalization can have the effect of steamrolling local cultures. So you can go almost anywhere in the world and American pop music is much more listened to by young people than their own indigenous music. As Christians we learn that we have tremendous opportunity to preach the gospel all over the world, but we have to be aware that we shouldn't bring 
unwanted cultural accoutrements rather than developing local culture which can be redeemed. Properly armed with cultural awareness, Christians will see power for what it is but be aware of its dangers, will see globalization for what it is but be aware of its negatives, and then bring the gospel in its totality through the means that God is making available to us today.

PL: How does the Great Commission connect with the cultural mandate? Do you see continuity with the missional call? How do those two connect in biblical theology? WE: Following Harvie Conn, another of my mentors, the Great Commission is the cultural mandate recast appropriately in a fallen world in need of grace. So, like the mandate given to our first parents, it tells us to multiply and spread all over the world. Unlike the cultural mandate, it tells us to do that as gospel heralds. Like the mandate to our first parents, we're to subdue the earth, and some of that still goes on, but in addition to what Adam and Eve knew, we bring the Lordship of Christ our Redeemer to bear over every area of life. One of my favorite texts on that is Colossians 1:15-20, where the second person of the Trinity's mediatorship of creation is compared to his mediatorship and his reconciling of all things in the era of the church. Like the mandate given to our first parents, it's under God's covenant blessing. Jesus said, "All authority in heaven and earth has been given to me, and lo, I am with you to the ends of the age" (Matt 28:18, 20). So, it's the same, but in a far more greatly enhanced and corrective reiteration, since there has been sin and the need for grace to overcome it. There's continuity, but fulfillment, progress, and enrichment.

PL: So is there a definition as to what culture is that everyone would agree on, or is that impossible?

WE: I think it's pretty impossible. After working on this for a long time, I've got my little definition, restating the cultural mandate and applying it to cultural analysis. "Culture characterizes our calling here on earth. It distinguishes our common humanity, but also our differences. Culture can be positive, leading to human flourishing, or negative, bringing corruption and abuse. Components of culture are numerous and varied, making generalizations difficult. And although value judgments should be made cautiously, they are appropriate."4 Some remarkable scholars and commentators, both Christian and non-Christian, help us to understand the way the world works and its culture, but there is also a cultural dimension to the gospel, which transforms every area of life and changes culture. Finally, it's

4 Edgar, Created and Creating, 10. 
important to look at both the meaning and the power dimensions of culture. So culture carries meaning - it's full of symbols - but it is also about power in a good sense: authority and proper exercise of institutional values. All of that is wrapped up in the call to humanity today, particularly to redeemed humanity, to engage in the cultural mandate as it's been enhanced and been interpreted in the Great Commission.

\section{PL: Should Christians be involved in politics and political parties?}

WE: Absolutely. It's a loaded question because there are ways to do politics and ways not to do politics. In the 1980 s some false hope was expressed by conservative Christians that if we could only participate in the American political process we would see great change, but it doesn't seem to have happened. Part of the reason is that perhaps we were naive in the way we were engaged in politics. Politics is a complicated, somewhat unclean business, and without the gift and a willingness to mix it up with people you don't agree with and arrive at compromises, you won't be effective. Christians should get involved in politics. Some are called to be professional politicians, most of us are called to be politically aware, to vote, to participate in the local politics we know. It's interesting to note that some of the people who are the most angry with the way things have come out in the recent election, on either side, are those who didn't do much locally to begin with. And some of them didn't even vote. I have little sympathy for that. Politics isn't going to save the world any more than the arts or business, or any other kind of false messianic hope. We are in a battle at each level and in every sphere for God's righteousness, and we can do our part and see a bit of progress if we keep our goals modest and don't think of a giant culture war where the white hats have to win everything. We are just to do God's work and beg him for revival and awakening.

PL: Do you believe that a healthy view of culture from a biblical perspective mandates some sort of a public proclamation, a public theology, and if so, how does culture inform that task?

WE: I believe very strongly that theology ought to be public in the sense that many of the issues that theology deals with are of interest to the public. Go through Jesus's teachings, and it is hard to find any that are just private. His views on government, his views on poverty relief, his views on family, these things are of deep importance to the public.

PL: How did some of the great names in the Christian tradition impact your work - C. S. Lewis, Francis Schaeffer, Cornelius van Til, and Os Guinness? How 


\section{have they shaped this book?}

WE: The four of them in very different ways. Lewis oddly, but perhaps tellingly, was quite hesitant to engage in culture in his theory. In his practice, he did a lot of that. So I wrestle with him a great deal because he is one of my heroes. I think his hesitancy with culture is because he doesn't want it to replace the worship of God with something earthly, and thus he is zealous to guard against any idolizing of culture. He sees culture as a preparation for the gospel, maybe as a means to nurture our imagination, which is a wonderful way to be ready for seeing what God sees, but he did not advocate a Kuyperian kind of cultural transformation.

Schaeffer was all about cultural apologetics. He not only used illustrations out of every realm of culture but practiced cultural engagement at L'Abri. For example, we had an arts festival there which was very popular and encouraged young artists to come and learn to paint and sculpt and dance and so on. So he was very aware of the incarnation of the gospel into cultural areas, and in some ways he was ahead of his time. For example, his little book called Pollution and the Death of Man was prescient about the dangers of pollution, not just ecological dangers, but aesthetic dangers. ${ }^{5} \mathrm{He}$ wrote a book about the arts, and about the rise and fall of Western civilization.

Van Til didn't say a great deal directly about cultural engagement, but he constantly referred to Kuyper, the Kuyperian tradition, and to the wisdom of unbelievers, and his area of specialty was philosophy, so he was very aware of that, and he also enjoyed literature. His presuppositional apologetics really grounded me in the possibility of cultural awareness.

Guinness has written extensively about culture; although he's primarily a sociologist, he's very aware of history. A couple of his recent books, Renaissance and A Free People's Suicide, detail the cultural reasons why the West is losing its civilizational saltiness. ${ }^{6} \mathrm{He}$ has this remarkable ability to find people who can have insights into why things are going one way or another. One of my favorite books of his is called The Call. ${ }^{7} \mathrm{He}$ marshals an array of people who either said good things about calling and were called to do something good, such as John Newton when he gave up slavery, or bad things, such as Picasso when he became obsessed with painting and couldn't free himself of his pagan obsessions. So, one of the reasons that I dedicated

5 Francis A. Schaeffer, Pollution and the Death of Man (Wheaton, IL:Tyndale House, 1970).

6 Os Guinness, Renaissance: The Power of the Gospel However Dark the Times (Downers Grove, IL: InterVarsity Press, 2014) and A Free People's Suicide: Sustainable Freedom and the American Future (Downers Grove, IL: InterVarsity Press, 2012).

7 Os Guinness, The Call: Finding and Fulfilling the Central Purpose of Your Life (Nashville: Nelson, 2003). 
the book to him and Jenny is they've been such mentors, friends, and supporters. Also, Os opened my eyes to historical and social trends that I might not have seen without his teaching. He basically says Christian apologetics has been so tied to philosophy and the theistic proofs that it has ignored the social dimension of human existence. So he pleads for the sociology of knowledge, plausibility structures, and almost single-handedly changed the awareness of much of the Christian community on these things.

As we come up to the Reformation celebration next year, I was looking at Luther, who famously said, "Three areas of life are in dire need of reformation: the preaching of the Word, government, and the family." Luther's Protestant Reformation was culturally aware, and without building on those shoulders we probably wouldn't be doing what we are doing today.

PL: So your book on culture came out on the five-hundredth anniversary of the Protestant Reformation. What reformation do you hope your book will have on our understanding of culture, and how are you standing on the shoulders of the Reformers?

WE: It would be arrogant to suppose one might begin a reformation! If people read it and were inspired, I hope they might recapture the seriousness with which the greatest Christians in history and our biblical heroes have celebrated culture, whether it be in awareness of cultural trends or the cultural dimension of missions and worship and in the transformation of culture. That's not triumphalistic. It's simply obedient. If people could read the book and be encouraged to engage culturally, I would be encouraged. Although I have convictions in this area, I don't spend a lot of time in the book criticizing other views. Some of them get a walk-on part, but I wanted the book to be mostly positive and cause people to reflect.

PL: Is there anything outside of the sweep of culture, and how does culture lead us into the eschaton?

WE: Culture is the primary calling of the human race; nothing is outside it. However, properly speaking, God is not a cultural being. He created culture. He interacts with it, and the gospel comes with cultural clothing, but he's outside of it. While worship - where we directly pray to God, honor him, and sing to him - has a cultural dimension, it is hardly a cultural activity. Anthropologists study human worship and they think of it as a cultural thing, but that sounds relativistic to me, as it doesn't directly fall under the purview of culture.

PL: So is there culture after the end comes and the new beginning is upon us? 
WE: I believe so. I've a little chapter on that in the book. Some of it is from Revelation, some of it is inference. When Jesus says, "I will make you a ruler of five cities or ten cities" (Luke 19:17, 19), while that may not be completely literal, there's no reason to think there isn't rule over some entity like a city or a human grouping, a cultural pursuit. When Revelation tells us the kings come marching into Jerusalem with their glory (Rev 21:24), the word glory probably has a reference to something like their treasures, a cultural concept. When the world is destroyed (2 Pet 3:7), I don't believe it's the good part, the positive cultural redeemed aspect that's destroyed, but it's the cancer. What will remain will shine forever, although we don't know what culture is going to be like in heaven. Lewis speculated on it, and it's fun to do that, but we don't know. We do know that we will be spiritual beings, as Paul says in 1 Corinthians 15 and that the center of heaven will be Jesus Christ. Even as spiritual beings worshiping him, whatever cultural activities there will be will be in order to draw us closer to Jesus, and the details I'm dying to find out.

\section{PL: Is there jazz in heaven too?}

WE: That's a hard question, actually, because if you say no, that means that all the skill, the music, the improvisation, the compositional devices that make jazz or any other kind of music are extraneous, irrelevant. I'm willing to say that the kind of music we create here, to the extent that it glorifies God, and maybe to the extent that it needs further redeeming, will be in heaven. All that music in the book of Revelation has got to be set to some tune. Is it going to be some unearthly, never-heard-before tune? I doubt it, any more than the words are.

PL: So you conclude your book by focusing on principles and guidance to help us think culture through. How would you like someone to take this book and apply it in a specific area as they wrestle with issues of culture in their own calling?

WE: My biggest hope would be that they would do just that. I'd like them to develop deeper thinking about the political realm, the family, the self, and the art, and then take some of those principles and apply them not just theoretically but concretely. Steve Turner has written a beautiful book called Imagine about the biblical worldview in the arts, and he's a poet himself and a journalist and so forth. ${ }^{8}$ Calvin Seerveld has done it in the visual arts, and James Skillen in the public, civic realm. ${ }^{9}$

8 Steve Turner, Imagine: A Vision for Christians in the Arts (Downers Grove, IL: InterVarsity Press, 2001).

9 Ed. note: see James W. Skillen, "Witness in the Public Square," Unio cum Christo 1.1-2 (Fall 2015): 159-71. 
PL: On some of the highlights of your work, is there something you'd really like to say?

WE: You mentioned the contra mundum texts, which seem to say, "Don't have anything to do with the world," therefore, "Don't have anything to do with culture." I argue that's not what's being said. One of my favorite places to go when we're talking about the ongoing validity of culture is in 1Timothy 4, where Paul warns his young friend and the rest of us that in the last days there will be doctrines of demons that will say things like "Don't get married" and "Don't enjoy food" (1 Tim 4:3). I go into some length about why Paul picked those two areas, although he could have picked others. But I think marriage says something about God's good intentions for us as families and how celibacy in itself is no virtue. Again, going back to people like Luther and Calvin. Luther thought extensively and wrote about the evils of celibacy. He said, "If there's one in a thousand who are called to this, that would be a lot." While he talked about the temptations of staying celibate because you can't handle it, he did so more about the beauties and the virtues of family. Carl Trueman argues that the Reformation did as much for removing a celibate culture and transforming it into a family culture as anything else. ${ }^{10}$ And then food, because in the New Testament, and to some extent still today, there's the cult of salvation through diet. The more sophisticated versions are gnosticism, but there were all kinds of teachings that if you abstain from this or don't do that, then you'll be with the other elites in the line to be enlightened. And Paul rails against this because the gospel is not about slavery to eating rules or any other rules, it's about a relationship with Jesus Christ, and that, too, is part of the cultural mandate. We're to not only subdue the earth in every area of life-in agriculture that means producing food that's good-much of the celebration in the Bible is around the table, and heaven is portrayed as a banquet table with the Lord. So that text shows us how God loves us to be culturally engaged and how the opposite of that is a doctrine of demons (1Tim 4:1).

PL: Talking about the Reformation, Calvin was struggling with music and some of the arts. Did the Reformed faith go wrong with Calvin, and have we corrected $i t$ ? How do we celebrate our great forefathers in this regard?

WE: I tremble, but I'm going to say it: Calvin was a bit shortsighted in this area. He loved literature and knew about classical culture. He was not anti culture, but he was zealous to purify worship and to rid it of distractions, and maybe he threw the baby out with the bath water. That's why he wanted

${ }^{10}$ Carl R. Trueman, Luther on the Christian Life (Wheaton, IL: Crossway, 2015), 175ff. 
only psalms and a couple of other canticles sung with the sparsest music. The French translations of the Psalms are beautiful. But even that he wanted them translated and rendered into poetry is a bit of a contradiction. In his great zeal to reform worship there was a kind of iconoclasm which went a bit over the top, for instance in taking the organ out of Saint Peter's church.

Kuyper argues that taking the arts out of the church meant placing them where they really belong, which is in the world of culture. As a Dutchman he says that when the paintings and visual images were taken out of the church they were put into the hands of extraordinary artists, and he celebrates the golden era of Dutch landscape art, and Rembrandt. I appreciate his zeal to justify Calvin, as he has a point that Calvin's worldview had great implications for the arts. But that worldview was only put into application in the arts generations later.

Maybe the Lutherans did a better job. The Reformation was a wonderful time, but it was not a golden age, and we need to build on what's good and look again at what needs to be developed and refined. It's a happy thing that Reformed Christians are rediscovering the role of the arts. We hope they don't idolize them, necessitating another reformation of iconoclasm. But it's a happy development, and I think it's one that Calvin would have approved in seed form had he gone to sleep and woken up several centuries later.

\section{PL: Would you say that sinfulness can affect our aesthetic impulses?}

WE: Sure. Calvin was aware of the sinful impulse to take visual objects and in the name of venerating them actually to idolize them. Following Erasmus and the others he thought the easiest way was to just get them out. But there's a reverse kind of sinful reaction, which is that if I purify my life and live in just a white living room and have no art, anywhere, so that I can think I'm safe. But that doesn't work either.

PL: Well, Professor Edgar what a joy to hear your reflections on your life, your ministry, and your work on culture. What do you want to give us as your concluding salvo in this interview today?

WE: One of my mottos, which was encouraged by African American people that I've spent a lifetime studying, is not to seek happiness but to seek joy. And the difference is that happiness is the superficial emotion that makes us feel good, like if we had only dessert in our meals. Joy is a deeper emotion that is profoundly grateful and free, having been through the dark places and having tasted the way God can bring us through. As my students know, I like to say neither optimism nor pessimism are biblical. The difference is the optimist thinks we are in the best of all possible worlds and the pessimist 
fears he may be right. And the problem with pessimism is that it is not dark enough. So Jean-Paul Sartre was a pessimist, but he's a lightweight compared to the author of Ecclesiastes, which really is dark because our view of sin is terribly dark. My former teacher C. John Miller used to say, "Cheer up, you're far worse than you think," but then he would quickly add, "but God is far greater and more powerful than you think." So, optimism isn't bright enough. Optimism is Pollyanna, things are going to turn out OK, whereas hope, Christian hope, means that things are going to turn out OK, but it's not things that we're deeply worried about, but our relation to God. If that turns out all right, then I can be a truly joyful and hopeful person. If everything else goes well but I don't have that, then life's not worth living.

PL: Thanks so much, Bill. 


\section{Book Reviews}

Thomas Schreiner. Faith Alone-The Doctrine of Justification: What the Reformers Taught ... and Why It Still Matters. The Five Solas Series. Grand Rapids: Zondervan, 2015. Pp. 288.

The year 2017, five hundred years from what is often considered to be the start of the Reformation, provides an opportunity to reflect on the tenets of the Reformation anew. But what was distinctive about the Reformation, and do the pillars of the Reformation still stand after five hundred years? Enter a new series of books on the five solas of the Reformation, edited by Matthew Barrett. The first contribution to this series, from seasoned New Testament scholar Thomas R. Schreiner, defends biblically the doctrine of justification through the lens of "faith alone." This is a particularly relevant topic, since the doctrine of justification by faith alone has continued to be questioned from various directions since the Reformation. This volume is not overly technical, but provides an overview of key issues, which lands at strategic points to provide more detailed investigation.

Following a foreword by John Piper, Schreiner's contribution comprises three parts. Part 1 provides a historical overview of the doctrine of justification by faith alone. Schreiner helpfully begins (ch. 1) with the early church and argues that, although the doctrine of justification by faith alone was not as clear as we may like it to be, we do find evidence of justification by faith alone in several church fathers, beginning with the apostolic fathers; among others, he discusses here Clement of Rome, Ignatius of Antioch, Epistle to Diognetus, the Odes of Solomon, and Justin Martyr. He also discusses the views of Augustine on justification, which may not be quite as close to the Reformational view as some might wish. He then devotes four chapters to proponents of sola fide in the Reformation and post-Reformation periods: 
Martin Luther (ch. 2), John Calvin (ch. 3), John Owen and Francis Turretin (along with Richard Baxter, ch. 5), and Jonathan Edwards and John Wesley (ch. 6). Chapter 4 deals with the Council of Trent's response to sola fide. Schreiner argues, not surprisingly, that Luther and Calvin are both strong proponents of sola fide. Similarly, Schreiner finds sola fide emphasized in Owen and Turretin, along with the related doctrine of the imputation of Christ's righteousness (though he finds Baxter's position on justification to be wanting). Schreiner also argues that Edwards and Wesley ultimately held to sola fide for justification, though he admits their language can be confusing and perhaps not always consistent. Concerning Trent, Schreiner laments the anathemas pronounced on those who believe in faith alone for justification, and discusses whether or not they have in any way been rescinded.

In part 2, which is the longest portion of the book, Schreiner turns his attention in ten chapters to exegesis, especially (but not only) of Pauline texts. These include human sin (ch. 7), faith alone (ch. 8), faith in Jesus Christ (ch. 9), the importance of justification in Paul (ch. 10), righteousness in relation to justification (chs. 11-15), and good works and justification (ch. 16). Among other things, Schreiner argues that "works of the law" in Paul refers to the whole law and is not limited to boundary markers. For Paul, perfect obedience is required for justification, and the problem of sin means that no one (apart from Jesus) is able to meet this demand. He further argues that the righteousness of God prominently includes God's saving righteousness, but cannot be reduced only to his covenant faithfulness. Justification is not a process of being made righteous, but is a forensic declaration of a righteous status (entailing the imputation of righteousness), that is not based upon the believer's good works.

Part 3 then briefly considers some challenges to sola fide in recent years, focusing primarily on Roman Catholic theology (chs. 17-18) and the New Perspective on Paul, represented in the writings of N.T. Wright (chs. 19-20). In chapters 17-18 Schreiner outlines and critiques efforts of Roman Catholics and Protestants over the past twenty-plus years to paper over differences relating to justification, since the fissures between Rome and the Reformation remain significant and deep. Though Schreiner addresses the New Perspective on Paul throughout the volume, chapters 19-20 provide dedicated engagement with the arguments of N.T.Wright, for whom he expresses his appreciation. However, he remains ultimately unpersuaded by some of Wright's distinctive emphases pertaining to justification.

There is much to appreciate in Schreiner's treatment of justification. As one has come to expect from Schreiner, his discussions are fair, his style is easy to follow, and his conclusions are consistently sound. For example, 
Schreiner acknowledges the necessity of good works for salvation, even as he maintains a distinction between the basis of justification (Christ's righteousness alone) and the evidences of justification (the good works of the believer). Such care with terminology is to be applauded, since one does not often find this level of consistency and nuance in all writings on Paul's doctrine of justification. Schreiner also makes a strong case for the objective genitive reading of pistis Christou (and related phrases), referring to faith in Christ (rather than the faithfulness of Christ). There is also quite a bit in this volume that supports the imputation of Christ's righteousness as a concomitant of sola fide.

The style and tone of the book make it accessible to readers of various levels. I envision this will be an especially helpful work for pastors and students seeking an overview of issues such as the righteousness of God, along with some clarity in how to respond to the New Perspective on Paul. Moreover, it is immensely refreshing to find a work of New Testament scholarship addressing not only exegetical matters, but also important works from the history of interpretation. As it has been noted in another context, often the best arguments in the history of interpretation have never been refuted; they have been simply ignored or forgotten. The arguments of Owen and Turretin, for example, have often not been engaged sufficiently by New Testament scholarship, but at points (including issues pertaining to justification) their arguments would need to be refuted for newer formulations to be compelling to those familiar with the church's rich traditions. Schreiner's interaction with these Reformed stalwarts, along with his capable biblical exegesis, reinforces the hesitancy we should have to embrace redefinitions of justification.

In sum, Schreiner has demonstrated that there is ample, biblical reason to hold steadfastly to the doctrine of justification by faith alone, despite questions that have been raised about this doctrine over the years. This is a fine resource that has set the bar high for this new series on the five solas of the Reformation.

BRANDON D. CROWE

Associate Professor of New Testament Westminster Theological Seminary Philadelphia, PA

Scott H. Hendrix. Martin Luther: Visionary Reformer. New Haven: Yale, 2015.

This book should rightfully take its place as the new standard biography of Martin Luther. Scott Hendrix-Professor Emeritus of Reformation History, Princeton Theological Seminary-has integrated the best of recent Luther 
research with an awareness of questions raised by social history, including late medieval pieties and political systems. Complementing this strong academic foundation, the narrative flows with clear writing and wellorganized chapters, making it useful for specialists and approachable for popular audiences.

In his preface, Hendrix lays out some of his reasons for writing a new Luther biography, beginning with the fact that Luther remains hugely significant in world history. Throughout the work, Hendrix presents Luther and his work with a balanced analysis that clarifies the historical record. While this grounded approach to biography may sound obvious, it is a valuable contribution because of the extensive mythology (both positive and negative) and misinformation that has developed around Luther over the centuries.

This book also succeeds in presenting Luther's life in a single, readable, up-to-date work. This is no small accomplishment. Despite voluminous scholarly research on Luther, a readable, original, and comprehensive biography of the reformer has long been desirable. Roland Bainton's monumental Here I Stand was published in 1950. Martin Brecht's three-volume Martin Luther is too big to be useful to popular audiences. Other booklength treatments of Luther tend to retell the story without adding the insights of contemporary research, to focus on Luther's theology, or to deal with narrower aspects of Luther's life. Especially in light of the five-hundredth anniversary of the Reformation this book fills an important role in Luther studies. More modestly, Hendrix explains that he encountered the need for a book like this as a teacher seeking texts to assign or recommend. That teacherly desire to tell the story in an accessible way gives the work a warm tone throughout.

Hendrix also describes at the outset the lenses through which he will view Luther's life. He begins by applying Luther's teaching that people are "simultaneously sinner and saint" to the reformer himself. The idea that people cannot fully understand their own mixed personal motives remains one of Luther's more provocative formulations. Recognizing Luther's complexities and even internal contradictions offers the benefit of a well-rounded appraisal of Luther as a person, which happens to be congruent with Luther's own view of human nature and experience.

The body of the work is divided into two halves: first, Luther's early life and career up to the events surrounding the 1521 Diet of Worms; second, his work as a reformer from his return to Wittenberg in 1522 until his death in 1546. The early chapters provide a good introduction to Luther's world and worldview. Chapters on Luther's early career as an Augustinian brother 
and theology student are illuminating, especially Hendrix's description of Erfurt's lively intellectual life, which included a circle of humanists.

When it comes to Luther's so-called "Reformation discovery," Hendrix presents Luther as standing in continuity with his times-especially through the influence of his mentor Staupitz - even as his insights began to set him on a collision course with the dominant theologies and powers of the time. By not obsessing over a single breakthrough moment, Hendrix keeps the focus on Luther's steady development as a reformer whose ideas were propelled both by personal interests and external factors. Theologically, the focus rightly remains on the power and promise of justification by faith.

Luther's final twenty-five years provide the material for the second half of the book. This is a helpful corrective to the tendency in Luther studies to focus more on the dramatic early years and less on events that followed. To show the great effort that Luther put into the ongoing progress of the Reformation, Hendrix describes Luther's cooperation with colleagues like Philip Melanchthon, John Bugenhagen, and Justus Jonas. Based on his previous research of Luther's family dynamics, Hendrix is also able to provide thoughtful assessments of the personal relationships that shaped Luther's life. Passages about Luther's family_including his sorrow over the death of his daughter Magdalena - are consistently touching and insightful.

Controversial aspects of Luther's career, such as his role in the Peasants' War of 1525 and his ugly writings about Jews and Muslims, are treated forthrightly and without defensiveness. This is a good example of the "simultaneously saint and sinner" thesis in action. Hendrix's final chapter successfully weaves together important themes like personal loss, the challenges inherent in organizing diffuse groups of Protestants, and the events surrounding Luther's own death. Hendrix's coverage of Luther's later years paints a picture of struggles, chosen and not, including Luther's stubborn concern for good preaching and for effective institutions that serve spiritual and social well-being.

In conclusion, this book is biography of the highest art. It deserves to be known and used as the standard English-language biography of Martin Luther.

MARTIN LOHRMANN 
Larry Siedentop. Inventing the Individual: The Origins of Western Liberalism. London: Penguin Books, 2014. Pp. 434.

After attending Hope College in Michigan and Harvard University, Larry Siedentop made a distinguished academic career at Keble College, Oxford. He wrote on the French liberal thinkers Tocqueville and Guizot and published a noted Democracy in Europe (2001). A recurring theme of interest in his work has been the fact that the roots of modern liberalism, and particularly the values of equality and individual freedom, are to be traced primarily to the influence of Christianity on Western culture.

The central thesis of Inventing the Individual is therefore highly unfashionable and certainly not something propagated in secular universities-that Christianity contributed positively to the growth of Western freedoms: "Secularism is Christianity's gift to the world, ideas and practices which have often been turned against 'excesses' of the Christian church itself" (p. 360). Siedentop also daringly contrasts Christianity and Islam at their inception: "Enforced belief was, for Paul and many early Christians, a contradiction in terms. Strikingly, in its first centuries Christianity spread by persuasion, not by force of arms - a contrast to the early spread of Islam" (p. 361). So this book invites us sotto voce not to be browbeaten by slanted secularization theories and to affirm how positive the message of Christianity was for the development of human flourishing.

The title of the present work is a little deceptive, perhaps because of no fault of the author - who knows? We might expect the book to run through the Reformation to the French Revolution and beyond. However, its center of interest is much further back, and the main body of the book deals with the development of the notion of the individual up to the time of the Reformation. There is a final chapter on "Dispensing with the Renaissance" and an epilogue on "Christianity and Secularism." In these two chapters Siedentop goes against the current flow of present interpretation of the meaning of Renaissance and secularism.

The twenty-five chapters of the book are divided into sections that deal successively with the world of antiquity, the moral revolution of Christianity, the idea of fundamental laws, Europe acquiring its identity, a new model of government, and the birth pangs of modern liberalism. The author finds the roots of modern liberalism in the canon lawyers of the fourteenth and fifteenth centuries, not yet in coherent theory, but in the seeds that bore fruit two centuries later. He identifies several important elements, such as equality as the basis for the legal system, the belief that enforcing moral conduct is a contradiction in terms, the defense of individual liberty through fundamental 
natural rights, and representative government as appropriate for a society resting on moral equality. These ideas were not yet combined to create a program for the sovereign state and secularism. That development came later, "when the fragmentation of Christianity led to religious wars, civil and international. In an attempt to restore a broken unity, Catholic and Protestant churches resorted to force, (which) led sensitive minds gradually to put together the credo of secularism, drawing on the insights of so-called 'medieval' thinkers" (p. 332). So liberalism was not born naturally from Christianity, but indirectly, as a result of conflict when "liberal" or "modern intuitions generated by Christianity were turned against attempts to 'enforce' belief" (p. 333). Henceforth the epithet "barbarous," which had hitherto been applied to pagan hordes, was attached to the churches.

From our point of view, the main interest of Siedentop's cultural narrative lies in its capable debunking of two modern shibboleths, the myths we have been conditioned by modernism to accept as self-evident, firstly, that classical antiquity was a haven of freedom and the aspirations of human nobleness, which Christianity overlaid with darkness, violence and oppression, and secondly, that the Renaissance was the breaking forth of a new humanity, a harbinger of the liberating Enlightenment, which put paid to the barbarities of the dark ages when religion dominated in the medieval period and the Reformation.

Chapters 4 to 6 of this challenging book are a tonic. They made me think that we have somewhere lost the power of the gospel and its social impact in theological niceties. Contrary to what we were told in school, the ancient family, the ancient city, and the ancient cosmos itself were characterized by forms of oppression that can only be described in terms of inequality, hierarchy, and fate. The core of ancient thinking was the assumption of natural inequality, which meant that rationality was not equally distributed among mankind. "Whether in the domestic sphere, in public life or when contemplating the cosmos, Greeks and Romans did not see anything like a level playing field. Rather, they instinctively saw a hierarchy or pyramid” (p. 51). Siedentop does not have much difficulty (although he is not always helped by some of his references, who are "Enlightenment agents") in showing that the much-maligned apostle Paul, following the teaching of Jesus, turned the world upside down. Christ, not Augustus, is king. Paul "invented Christianity" by reconstructing human identity (pp. 58-62). Christ reveals God acting through human agency and redeeming it. Rationality is reshaped by faith, and Paul overturns inequality for equality, bringing a new transparency into human relations and a God-given foundation for human action in the free action of love. Paul "attaches to the historical figure of 
Jesus a crucial moment in the development of human self-consciousness" (p. 63). Later Christian apologists will give social order a foundation in law and conscience. Martyrs will demonstrate the power of the individual will founded on conscience, in stark contrast to the heroism of antiquity (p. 80). This demonstration is capital for today, at a time when the Christian church needs to discover anew the difference between Jerusalem and Athens, rather than kowtowing to Athens.

Siedentop's story is that "Christian egalitarianism (the 'care of souls') first shaped the distinction between spiritual and temporal authority, creating a sphere for individual conscience" (p. 321). Egalitarian moral institutions had gradual and transforming power. Slavery was undermined early on, and the permanent inequalities of social status came under increasing threat in the long haul, with accountable sovereignty replacing tyranny. This movement focalized not in the Renaissance but in the later Middle Ages; the challenge for early modern Europe was transforming moral claims into social status (pp. 338-39). Siedentop criticizes the accepted wisdom on the Renaissance: "We have inherited from historians such as Burckhardt the view that the individual re-emerged and burst into bloom in the Italian Renaissance (which) marked the end of a kind of religious tyranny, a tyranny of the mind-opening European eyes to the apparently far wider range of values and interests exhibited in classical antiquity." Any suggestion that egalitarian moral values might be traced to Christianity became outlandish. This, it is suggested, is far from the reality of things. Even though Siedentop has no wish to depreciate its attainments, he maintains that the Renaissance has been grossly inflated; the idea that it marked a decisive break separating ignorance and superstition from freedom and progress needs to be called into question (pp. 334-36). Uncoerced belief, the role of the individual conscience, legitimate authority, and freedom of choice and responsibility are products of Christianity in its developments prior to the Reformation.

As far as antiquity, the Renaissance, and the rise of modern egalitarian values are concerned, we have been led up the garden path by the virulent anticlericalism of modernism, which is still with us in its postmodern form as anti-Christianity. Siedentop invites us to review the accepted wisdom and take seriously the message of the gospel for moral egalitarianism. This might be essential when it comes to thinking about the limits of egalitarianism, and the way it is tipping over into new forms of tyranny today.

PAUL WELLS 
Brad S. Gregory. The Unintended Reformation: How a Religious Revolution Secularized Society. Cambridge: Harvard Belknap Press, 2012. Pp. 574.

It has become fashionable among sociological cognoscenti to speak of the consequences of the Reformation as "unintended." Brad Gregory's title seems to be following Charles Taylor's lead in A Secular Age, where Taylor resorts to the "unintended" motif several times. With the fifth centenary of Luther's Wittenberg door approaching, it is to be expected that there will be some discussion about the impact and relevance of the events that followed on the modern world.

The "unintended" line has some advantages. It allows some of the consequences of the Reformation to be linked with the present, while ultimately letting the protagonists off the hook as far as undesirable outcomes are concerned. It also has the advantage of avoiding the overkill of previous interpretations, both positive or negative, which constructed an expressway between the Reformation and the Enlightenment, and even in some cases between Calvin and Voltaire! A certain agnosticism appears legitimate concerning the engendering of modernity by the Reformation. Direct links are tenuous at best, and "unintended consequences" are speculative construals, with questionable feasibility.

One gathers that this book was written over a number of years, showing as it does an impressive garnering of knowledge and reflection - the detailed endnotes cover 140 pages, and there is a considerable index. The author, who is associate professor of history at the University of Notre Dame, shows considerable breadth of cultural acumen in this analysis, which concerns the present as well as the past. In fact, what he says in a conclusion entitled "Against Nostalgia" is in some ways the most stimulating part of the book, following on from six "long-term narratives" on the themes of the sidelining of God, the relativization of doctrine, the privatization of worship, moral subjectivism, consumerism, and the social secularization of knowledge.

Gregory's ace in the hole is that he is not a common, garden-variety period historian who concentrates on a limited time scale and throws out a few hazardous conclusions. Each of the themes is presented in the flow of history over the period, so avoiding the compartmentalization that is the blight of many historical studies. Gregory writes cultural history, and he does so in an enthralling way. His perspective is that "the historical intelligibility of the past in no way implies the inevitability of the present"; the method is described as "genealogical, in seeking to identify and analyze long-term historical trajectories with their origins in the distant past that happen to remain influential in the present." Reformed theologians will 
have no difficulty appreciating the assertion that beliefs influence behavior, that beliefs differ radically, and believers and antireligious "believers" (sic) can both be unperturbed by the hyperpluralism to which they contribute (pp. 11-12).

So the introduction predictably engages supersessionist models of history that interpret the past as a "sequential series of epochal blocks" that account for the present. In this respect even Taylor is not immune from criticism (pp. 9, 14).The present is incredibly diverse and includes differing religious worldviews; the question remains as to how one development produces such a diversity of variegated convictions in the ways people believe and live. Apart from that, the supersessionist approach, advocated by both Enlightenment crusaders and postmodern deconstructionists, naïvely assumes that the secular present has triumphed over the religious past, a world left irretrievably behind. Gregory's critique is juxtaposed to these diagnoses: there is no self-evident reason for the exclusion of religion or for taking it to be done for. Religious worldviews of undeniable intellectual sophistication exist today "as part of Western hyperpluralism. They have not been 'left behind' or 'overturned' by 'modernity' or 'reason."'The conclusion is that "philosophical efforts to contrive a universal, self-sufficient, rational replacement for religion, for all their historical intelligibility and desirability in the context of early modern Christian doctrinal controversies, were selfdeceived from the outset, and those intellectuals who continue to carry on likewise are engaged in a similarly self-deceived enterprise." In fact, the modern Zeitgeist has singularly failed to provide a rational substitute for religion with respect to life questions. Moreover, it condemns us to Zygmunt Bauman's moral blindness and directionless liquidity, as history runs in a direction no one planned and no one particularly wished it to take (pp. 381-84).

The argument is unpacked as one might expect. Gregory suggests that present confusion about human flourishing is traceable to the changes set in motion by the Reformation. The late medieval institutional situation was marked by a gulf between faith and practices that raised questions as to how life might be lived in a more consistently Christian way. The protagonists of the Reformation sought to answer the problems, but unwittingly disrupted the religious fabric that held early modern societies together. The turn to the Bible and the authority of sola Scriptura was inconclusive doctrinally and moreover led to a new complex of unresolved problems and antagonisms. Unlike some commentators, Gregory sees religious conflict and war as a factor of disenchantment. This aspect could have been developed further, as suggested by Joseph Lecler's neglected classic Toleration and the Reformation (1960). 
The outcome of conflict among the antagonists engendered a desire to render life stable and secure by the eventual therapeutic distinction of public and private spheres, with religion functional in the subjective sphere and objective reason ruling in public life. The unintended consequences of the Reformation became progressively visible in epistemology, morals, and political life. The individualization of truth claims led to tolerance and freedom of conscience, morality was removed from the realm of metaphysics, and individual "rights" came to the fore politically with the separation of church and state.

How was it possible to begin with Reformation and end up with secularism? Gregory seeks to trace this story from various angles; he claims that it issues from the fragmentation not only of religious belief, but also of secular foundationalism. Prominent in the present situation are the following assumptions: that science undermines religious belief as the source of all truth, whereas it does nothing of the sort; that morals can be unmoored from their Christian foundation in the secularized "values" of liberalism, whereas faith assumptions that have no naturalistic basis are illicitly smuggled in; and that the pursuit of knowledge is a purely secular enterprise where religion has no place, whereas the secular academy would benefit by more openness in unsecularizing itself (pp. 284-387). Reason has failed to produce satisfying answers to Life Questions, and we are left with a core ideology reduced to the liberal autonomous self and its gratification in the hedonism of an obsessive consumer "kingdom of whatever" (p. 377).

Gregory's narrative, which issues in a head-on critique of secularism, is as convincing as it is impassioned. He exposes with disturbing lucidity the plight of the present vacuum in which secularism, capitalism, and consumerism make a heady cocktail that erodes communitarian values, in which self-interest dominates, and in which valueless economics become an end. "Ash-heap lives," as Francis Schaeffer somewhere said.

One question that remains, however, is "what if?" Even if we tend to agree with the author that the Reformation had unintended consequences, the filiation, even if "unintended," is perhaps less direct than Gregory suggests. Was Luther's hope not originally a renewed church, and did Calvin cease to hope for a return of the church to the biblical gospel? Was not the Reformation, in its day, a great opportunity lost?

And then there is another twist in the story, related to the ongoing spiritual struggle between light and darkness. Did the Reformation generate "unintended consequences" or idolatrous opposition? This question may lie outside the walls of secular academia - but in order to have a global vision of the effect of the Reformation on the present, could not Groen van 
Prinsterer's and Abraham Kuyper's analysis of the idolatrous opposition of revolutionary politics against belief in God help us see that there is more to our situation than the spin of the unintended?

PAUL WELLS

Andrew T. B. McGowan. Adam, Christ and Covenant: Exploring Headship Theology. Leicester: Apollos; London: Inter-Varsity Press, 2016. Pp. xvi +221 .

Andrew T. B. McGowan argues that he stands in a trajectory set by John Murray and wants to bring Reformed theology more into accord with the Bible. The issues under consideration are covenant and headship. He divides his work into three sections: historical considerations, a constructive proposal, and implications. It will be most helpful to review the book according to these three divisions.

The historical section begins with a chapter on covenant theology in the history of the Reformed tradition, but the bulk of the historical treatment covers debates about covenant theology beginning in the twentieth century. It is helpful that before he makes a positive theological case, McGowan surveys the positions of Karl Barth and followers, then John Murray, Meredith Kline, and the Federal Vision (FV) movement because these writers are the ones who determine the issues and the context of current debates about Reformed covenant theology. McGowan calls for an irenic reading of debate partners and is usually very good at reading irenically himself. Although many treatments of Reformed covenant theology in the sixteenth and seventeenth centuries exist, far fewer examine changes in covenant theology beginning in the twentieth century. McGowan has done us a favor by providing a succinct survey of the figures and issues involved.

That said, there are some important things to note about this historical section. First, it appears that McGowan sees a closer relationship between Barth, Murray, and FV than many would be willing to accept, including myself. This is not to deny that there may be some shared interests between them, but it is at best a contentious move to cite positions from these three together as if they would all approve of one another. Second, McGowan's presentation of historical covenant theology raises some concerns. Writing that "covenant theology was expressed in different ways, such that there was no one definitive covenant theology, although most of the key elements were agreed" (p. 14) overstates the variations of early modern covenant theology. There is no denying that there were various expressions of 
covenant theology, but throughout the rest of the historical section, McGowan seems to suppose that this implies that there was major divergence within the Reformed tradition and that all models were equally acceptable as Reformed. He cites R. T. Kendall as one viable reading of the history of covenant theology, but Kendall's thesis has been criticized by the work of Richard Muller and those who appropriate his methodology. Third, McGowan does not highlight how the paradigm that Barth uses is entirely different from the traditional model: the differences between Barth's ontological appropriation of covenant and the traditional model are much greater than the book suggests. Lastly, there are times when McGowan seems to assume that a given challenge to the confessional position will prove to be correct. Although challenges to the Westminster Confession could prove to be more in line with Scripture, we should not assume the exegesis of one, or a few, commentators automatically will trump the consensus interpretation of Scripture found in confessions. The suggestion that "the WCF [Westminster Confession of Faith] has come to function in conservative Presbyterian theology in the same way as 'tradition' functions in Roman Catholic theology" is wide of the mark. Confessions are not dogmas and practices in addition to Scripture, but are the agreed-upon interpretation of Scripture by a given communion. Subscription is about agreeing to the stated interpretation of what Scripture teaches. McGowan is by far most critical of those who take a firm stance on being confessional, primarily Guy Waters and Michael Horton. In fact, he commends FV for focusing on the doctrine of the church because it is "the weakest area in Reformed theology" (p. 105), despite the fact that Waters and Horton, whom he criticizes most, have both written books on the doctrine of the church.

Part two of the book outlines a proposal for "headship theology," which focuses on the representative nature of the roles of Adam and Christ, but disconnects this representation from a covenantal structure. Two chapters expound on this proposal. The first deals with the Adam-Christ parallel of headship and makes many useful points. It rejects universalism, upholds the theological necessity of there being a historical Adam, and argues that "Adam is viewed as the representative head of the human race such that his obedience or disobedience would affect all those whom he represented" (p. 127). McGowan acknowledges that this is the position of classic covenant theology and maintains that this element, along with the parallel of Christ's obedience and penal substitutionary death, are the most persuasive conclusions from 1 Corinthians 15 and Romans 5. In this respect, the issue he takes with covenant theology is that it describes these headship roles in covenantal terms. The definite strength of this chapter is that it takes 
traditional Reformed positions on these passages. The chapter's weakness is that, although McGowan repeatedly calls for exegesis to norm theology, he provides little exegetical argument and spends more time restating what various modern and historical commentators say, giving his verdict about which is correct. That said, it is very much to his credit that he tends to favor the historical Reformed conclusions.

The second chapter of McGowan's proposal section describes the role of each biblical covenant in the history of the covenant of redemption: the Noahic covenant establishes common grace and the ability for all humanity to build culture, the Abrahamic covenant makes the promise of grace by faith, the Mosaic covenant delivers the law to God's people, the Davidic covenant promises an eternal king, and the new covenant fulfills all the promises made in other covenants. He describes the new covenant as being "through Jesus Christ" (p. 151). I imagine he avoids naming Christ the head of the new covenant because that would undermine his thesis that headship and covenant are separate. The crucial idea for McGowan's overall argument is the relationship between Abraham and Moses. He argues that grace is given first in the Abrahamic covenant and the law is given later to direct God's people in how to be faithful. This reduces the essential function of Mosaic law to spelling out the obligations of the Abrahamic covenant (p. 146). Some will celebrate this as an expansion of Murray's covenant theology, and, in fact, all should agree that the moral law, then and now, guides what faithfulness looks like. On the other hand, this seems to ignore much of the typology in the Mosaic covenant and how there is a condemning role of the law as well. Stating that the Mosaic law simply enumerates the obligations of the Abrahamic covenant could be read as the exact type of change to the promise covenant that Paul rejects in Galatians 3. I am not sure McGowan has explained the nuances of these issues sufficiently to prevent that conclusion.

Part three draws implications from noncovenantal headship theology. In the chapter on the law, he argues that the relationship he poses between the Abrahamic and Mosaic covenants brings some rapprochement with the New Perspective on Paul's views of the law. He affirms that justification happens by faith alone. Yet, he also argues that grace is at least chronologically, if not logically, prior to law, and so grace is followed by the obligation of obedience. The last chapter is about union with Christ. McGowan argues that imputation is crucial to the historic Reformed doctrine of justification, but does not state if he believes it to be true. He does appear to maintain justification as forensic. With stated dependence on Richard Gaffin and Sinclair Ferguson, he criticizes the ordo salutis model of soteriology in favor of union with Christ. 
All too often, McGowan insists his conclusions are biblical for the most controversial points for the Reformed community and argues by summarizing other literature, rather than providing exegetical or theological demonstration. Yet his work is a readable and clear presentation of a noncovenantal scheme that shows awareness of the major issues and figures.

HARRISON PERKINS

Queen's University

Belfast

Sinclair B. Ferguson. The Whole Christ: Legalism, Antinomianism, and Gospel Assurance-Why the Marrow Controversy Still Matters. Wheaton: Crossway, 2016. Pp. 256.

In this book, Sinclair Ferguson uses an eighteenth-century controversy in the Church of Scotland to illuminate, in both a theological and pastoral way, the reality of God's free grace in Christ.

The "Marrow Controversy," which took place in the Church of Scotland in the early eighteenth century, brought great division to the church and ultimately led to the first secession of 1732, where a number of distinguished ministers, led by the brothers Ralph and Ebenezer Erskine, left the Kirk. It began when a young candidate for the ministry was asked, during his "trials for licence" by the Presbytery of Auchterarder, to affirm a statement (called "the Auchterarder creed") that denied that repentance was a prior requirement for coming to Christ. The student refused and was ultimately vindicated by the general assembly, which condemned the presbytery's statement. In the subsequent debate, Thomas Boston, who favored the presbytery, urged a friend to read The Marrow of Modern Divinity, which he believed set out the issues very well. The Marrow was a pastiche of quotations from significant Reformation and Puritan writers, written in the form of a dialogue, which involved a minister counseling a young Christian on gospel issues, the other contributors being a legalist and an antinomian. This led to a great debate, which lasted a number of years. Later, the general assembly would also condemn The Marrow.

At its heart, the Marrow Controversy was about the nature of God's free grace in Christ Jesus. There had arisen a "legal" strain in the Kirk that so emphasized predestination that it denied the free offer of the gospel. The gospel was only to be offered to those showing "signs of election."This view prevailed in the general assembly for a number of years and had implications for the doctrines of repentance, assurance, and faith. On the opposing side, Boston, the Erskines, and the rest of the "marrow men," emphasized 
the unconditional free offer of the gospel and the unconditional freeness of God's grace in Christ. They were accused of being antinomian, whereas in reality they were anti-neonomian.

As Ferguson makes clear, the prevailing party in the church was guilty of making the gospel conditional, whereas the gospel properly preached teaches that there are no conditions to be met and, if there were, we would be unable to meet them. There is, however, a deeper point being made here, concerning the nature and character of God. As the author says, "One of the dangers Boston recognized was that conditionalism feeds back into how we view God himself. It introduces a layer of distortion into his character. For it is possible to see that no conditions for God's grace can be met by us yet still hold to a subtle conditionality in God's grace in itself" (p. 65). It has been said that almost every theological error can be traced back to a faulty doctrine of God, and that is certainly the case here. If we get God wrong, we will get the gospel wrong.

Throughout the book, we return again and again to this teaching that we must properly understand God so as to correctly understand the gospel. For example, when the subjects of legalism and antinomianism are being discussed, we read this: "Legalism at root is the manifestation of a restricted heart disposition toward God, viewing him through a lens of negative law that obscures the broader context of the Father's character of holy love. This is a fatal sickness. Paradoxically, it is this same view of God, and the separation of his person from his law, that also lies at the root of antinomianism. The bottom line in both of these -isms is identical. That is why the gospel remedy for them is one and the same" (p. 85).

One of the most striking aspects of the book is when the author argues that legalism and antinomianism are not equal and opposite errors, such that a legalistic spirit could be cured by moving in the direction of antinomianism and vice versa. Rather, both of these errors are really the same error expressed in different ways, and the cure for both of them is the gospel.

The positive teaching of the book concerns the doctrine of union with Christ. It is in Christ that every benefit and blessing is to be found, and so our understanding of union with Christ is the key to unlocking the gospel in all its fullness. The ordo salutis method of laying out the Christian life and experience may have some usefulness in helping to analyze various doctrines and their significance, but it can also lead to a failure to see the centrality of Christ and instead imagine that once we have received blessing A, B will follow, and then C, and so on.

The emphasis upon grace in this book should not be taken to mean that the law of God is insignificant. Rather, the key to understanding the law 
(like everything else) is to set it in the context of God and his grace. Sinners who are brought by the unconditional grace of God into union with Christ will love the law. It will be their hearts' desire to obey the law, not as a means of salvation and not as "our" contribution to sanctification but because they wholeheartedly love God, are thankful for his grace, and want to serve him as he has commanded us to do.

Towards the end of the book, the author turns to the theological understanding and pastoral application of the doctrine of assurance. In light of everything he has said already, he gives wise counsel to ministers of the gospel, and encouragement and hope to the struggling believer. The message is that we must look to Christ and realize all that we have in him, rather than focusing upon our own sin and failures in the Christian life.

Thirty-five years ago, I was writing my $\mathrm{PhD}$ on Thomas Boston. I was doing it part time, while serving as a parish minister of the Church of Scotland. My parish had six churches, five of which were only accessible by sea, four of them on islands in the Inner Hebrides! With a busy parish and regular travel round the islands, together with a supervisor who was deeply antagonistic to federal theology, my commitment to the dissertation was beginning to lag. Then, on January 5, 1981, at one of our Crieff Brotherhood conferences, Sinclair spoke on the Marrow Controversy and highlighted its significance for an understanding of the free grace of God in the gospel. My interest was immediately rekindled, and I went back to my work with new enthusiasm. I was grateful to Sinclair then, and, having had the pleasure of reading this book, I am grateful again.

This book should be read by every minister of the gospel and by every Christian struggling to understand and enjoy the free grace of God in Christ.

ANDREW T. B. MCGOWAN

Professor of Theology University of the Highlands \& Islands, Scotland 


\section{"A great Reformation handbook." \\ - Herman Selderhuis}

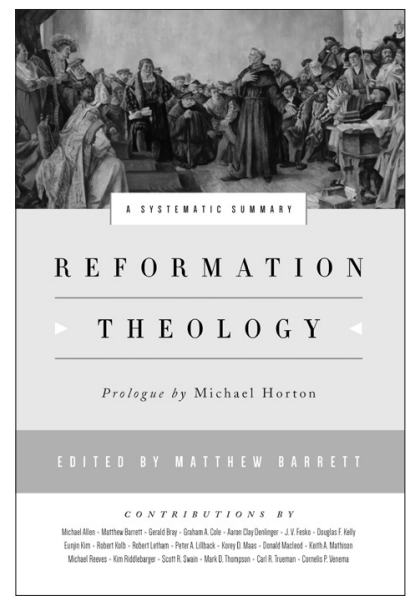

Offering a comprehensive summary of the major tenets of the theology of the Reformers, this volume convincingly demonstrates the Reformation's enduring importance for the church today.

"There is little doubt that Reformation Theology will ably serve the church and academy as a textbook for students and a reference work for scholars."

Chad Van Dixhoorn, Chancellor's Professor of Historical Theology, Reformed Theological Seminary-Washington, DC

"This delightful volume is a breath of fresh air in Reformation studies, putting theology back at the center."

Andrew Atherstone, Latimer Research Fellow, Wycliffe Hall, University of Oxford

"At a time when some are suggesting that for all practical purposes the Reformation is 'over,' Reformation Theology offers a needed corrective by showing the relevance of the Reformation for healthy church ministry and the Christian life today."

Philip Graham Ryken, President, Wheaton College 


\section{CONTRIBUTORS}

G. K. BEALE is J. Gresham Machen Chair of New Testament at Westminster Theological Seminary, Philadelphia. An ordained minister of the Orthodox Presbyterian Church, he is the author of, among other publications, The Book of Revelation, NIGTC (Eerdmans, 1999); A New Testament Biblical Theology: The Unfolding of the Old Testament in the New (Baker Academic, 2011); and Handbook on the New Testament Use of the Old Testament: Exegesis and Interpretation (Baker Academics, 2012).

JEAN-MARC BERTHOUD was born of missionary parents in South Africa, where he read history and English literature at the University of the Witwatersrand. Four years of doctoral research at the Sorbonne and the University of London completed his formal education. Conversion to the Christian faith in 1966 changed his orientation to long-term engagements in various fields of manual labor. Apologist and ethicist, he has written a number of books in both French and English, including Pierre Viret, the Forgotten Giant of the Reformation (Zurich Publishing, 2010) and his most recent publication, L'Alliance de Dieu à travers l'Écriture (L'Âge d'homme, 2012). He teaches at the Collège biblique de Lausanne.

YOUNGCHUN CHO received his PhD from Westminster Theological Seminary, Philadelphia, and currently serves at Jubilee Presbyterian Church in Philadelphia, Pennsylvania, as assistant pastor. He is author of Anthony Tuckney: Theologian of the Westminster Assembly (Reformation Heritage Books, 2017).

EMMITT CORNELIUS JR. is the director of spiritual health at Peregrine's Landing in Norcross, Georgia, and a chaplain at Emory Johns Creek Hospital in Johns Creek, Georgia. He earned his ThM degree at Dallas Theological Seminary (1985) and in 2005 became the first African American to receive a PhD from Westminster Theological Seminary, 
Philadelphia. He has published in several journals, including an article on church unity in Christianity Today and two articles on the Trinity in the Journal of the Evangelical Theological Society.

WILLIAM EDGAR is professor of apologetics at Westminster Theological Seminary, Philadelphia, and is currently professeur associé at the Faculté Jean Calvin, Aix-en-Provence. He directs the jazz band Renewal. His scholarly interests include apologetics, theology, the music of Brahms, aesthetics, African-American music, and ethics. He belongs to several learned societies, including the American Musicological Society, the Evangelical Theological Society, and the Society for Ethnomusicology. $\mathrm{He}$ is a senior adviser at the Trinity Fellows Academy and he sits on a number of boards, including the Huguenot Fellowship, which supports French speaking evangelical works. He has published several books and numerous articles in French and in English, most recently Does Christianity Really Work? (Christian Focus, 2016) and Created and Creating: A Biblical Theology of Culture (IVP Academic, 2017).

MICHAEL A. G. HAYKIN is professor of church history and biblical spirituality at the Southern Baptist Theological Seminary, Louisville, Kentucky, and director of the Andrew Fuller Center for Baptist Studies. He is the author of a number of books dealing with patristic and Baptist studies and is also the general editor of a forthcoming sixteen-volume edition of The Complete Works of Andrew Fuller (Walter de Gruyter, 2016-).

YANNICK IMBERT is professor of apologetics and church history at the Faculté Jean Calvin, Aix-en-Provence, France. He is a member of the theological commission of the Conseil national des évangéliques de France and of the editorial committee of the Journal of Urban Mission. He has written several studies on J. R. R Tolkien and is the author of an introduction to apologetics Croire, expliquer, vivre: Introduction à l'apologétique (Excelsis and Kerygma, 2014).

ROBERT KOLB, emeritus professor of systematic theology at Concordia Seminary, Saint Louis, is co-editor with Timothy J. Wengert of the translation of The Book of Concord (Fortress, 2000), co-editor with Irene Dingel and L'ubomír Batka of The Oxford Handbook of Martin Luther's Theology (Oxford, 2014), and author of Martin Luther and the Enduring Word of God (Baker Academic, 2016), Luther and the Stories of God: Biblical Narratives as a Foundation for Christian Living (Baker Academic, 
2012), and Martin Luther: Confessor of the Faith (Oxford University Press, 2009).

PETER A. LILLBACK is president and professor of historical theology at Westminster Theological Seminary, Philadelphia. He spent twenty-seven years serving as a pastor in Pennsylvania and Delaware. In 2000, he founded the Providence Forum. He has authored books and numerous articles in the field of the Reformation and post-Reformation era, including The Binding of God: Calvin's Role in the Development of Covenant Theology (Baker Academic, 2001). George Washington's Sacred Fire (Providence Forum, 2006) presents original research on the Christian faith of George Washington. His most recent work (as editor), Thy Word Is Still Truth: Essential Writings on the Doctrine of Scripture from the Reformation to Today (P\&R Publishing, 2013), brings together key documents on the inerrancy of Scripture.

FRANCES LUTTIKHUIZEN is a retired educator. She was scriptwriter and on-location advisor for "The Enlightened Ones," a part of the documentary The Protestant Revolt produced in collaboration between Capstone Films and Westminster Theological Seminary. Her latest publications include La Reforma en España, Italia y Portugal, siglos XVI y XVII: Bibliografía actualizada (MAD, 2009), and Underground Protestantism in Sixteenth Century Spain (Vandenhoeck \& Ruprecht, 2016).

CONRAD MBEWE is the pastor of Kabwata Baptist Church in Lusaka, Zambia. He is also the chancellor of the African Christian University, Lusaka, Zambia. He obtained his PhD from the University of Pretoria through the Cape Town Baptist Seminary. He is the author of a number of books, including Foundations for the Flock: Truths about the Church for all the Saints (Granted Ministries, 2011).

HANS SCHWARZ held the chair of systematic theology at the University of Regensburg, Germany, from 1981 to 2004 and is presently professor emeritus of systematic theology. He also taught at Trinity Lutheran Seminary in Columbus, Ohio, from 1967 to 1981. His more than forty former doctoral students teach at colleges and universities on four continents around the world. He has authored more than thirty books, his most recent being True Faith in the True God (Fortress, 2015), The Human Being (Eerdmans, 2013), and The Christian Faith: A Creedal Account (Baker Academic, 2014). 
PHILIP TACHIN has taught at the Theological College of Northern Nigeria in Jos and the National Open University of Nigeria. He is currently the executive chairman of the State Universal Basic Education Board in Benue State of Nigeria. He is the founder of the Reformed Outreach Initiative in Nigeria. He has written Calvin and Turretin on the Merit of Christ (2009) and articles on various subjects.

CARL R. TRUEMAN holds the Paul Woolley Chair of church history at Westminster Theological Seminary, Philadelphia. He is pastor of Cornerstone Orthodox Presbyterian Church in Ambler, Pennsylvania, a regular contributor to the Mortification of Spin blog, and author of numerous books in Reformation and Puritan studies, including John Owen: Reformed Catholic, Renaissance Man (Ashgate, 2007), Luther on the Christian Life: Cross and Freedom (Crossway, 2015), and Grace Alone-Salvation As a Gift of God (Zondervan, forthcoming).

PAUL WELLS is emeritus professor of the Faculté Jean Calvin in Aix-enProvence, France, and extraordinary professor at North West University (RSA). His doctoral thesis from the Vrije Universiteit, Amsterdam, James Barr and the Bible: Critique of a New Liberalism (1980), has recently been republished by Wipf \& Stock.

GARRY J. WILLIAMS serves as the director of the John Owen Centre for Theological Study at London Seminary in the United Kingdom and is visiting professor of historical theology at Westminster Theological Seminary, Philadelphia. As well as articles and chapters focusing on the doctrine of the atonement, his recent publications include Silent Witnesses: Lessons on Theology, Life, and the Church from Christians of the Past (Banner of Truth Trust, 2013) and a volume of theological meditations on the love of God, His Love Endures Forever: Reflections on the Immeasurable Love of God (Crossway, 2016). 


\section{CALL FOR ARTICLES FOR UNIO CUM CHRISTO}

The editorial committee invites the submission of articles (7,000 words maximum including footnotes) for future issues of the journal. Articles should be rooted in the Reformed faith and its confessional texts, and aim to be informative, edifying, missional in perspective, and relevant to current challenges facing the Christian faith worldwide.

We would like to encourage theologians (including research students) and pastor-theologians, particularly from countries in the developing world, to submit articles on issues relevant to the role of Reformed theology in their national and cultural contexts, and also book reviews.

We would also be pleased to consider texts translated into English that have already been published in journals in other languages.

Submissions will be peer reviewed before acceptance.

Upcoming numbers of the journal will present the following general themes:

2017/2 Luther, Calvin and the Reformed Tradition

2018/1 Current Debates in Reformed Theology - Doctrine

2018/2 Current Debates in Reformed Theology - Practice

2019/1 Old Testament Studies

2019/2 Ethics and Apologetics

Dates of submission of completed articles are six months before the appearance of the journal in April and October.

Before submitting an article, contact Bernard Aubert (baubert@wts.edu) with a proposition of subject and an abstract (less than 200 words). Details concerning formal presentation will then be communicated to the author together with approval of the proposition (Guidelines of Style are available at http://uniocc.com/journal/guidelines).

Paul Wells

Editor in Chief

Subscription to Unio cum Christo can be done through the website www.uniocc.com. Older issues of the journal are archived and available on the site. The two issues in 2018 will be devoted to doctrinal and ethical issues in Reformed theology. Contributions are invited. 



\section{Editorial Board Members}

\section{Africa}

Flip Buys, North-West University, Potchefstroom, South Africa Henk Stoker, North-West University, Potchefstroom, South Africa Philip Tachin, National Open University of Nigeria, Lagos, Nigeria Cephas Tushima, ECWA Theological Seminary, Jos, Nigeria

\section{Asia}

In-Sub Ahn, Chong Shin University and Seminary, Seoul, Korea Wilson W. Chow, China Graduate School of Theology, Hong Kong Matthew Ebenezer, Presbyterian Theological Seminary, Dehra Dun, India Benyamin F. Intan, International Reformed Evangelical Seminary, Jakarta, Indonesia

Kevin Woongsan Kang, Chongshin Theological Seminary, Seoul, Korea In Whan Kim, Daeshin University, Gyeongsan, Gyeongbuk, Korea Billy Kristanto, International Reformed Evangelical Seminary, Jakarta, Indonesia Jong Yun Lee, Academia Christiana of Korea, Seoul, Korea

Sang Gyoo Lee, Kosin University, Busan, Korea

Deok Kyo Oh, Ulaanbaatar University, Ulaanbaatar, Mongolia Moses Wong, China Reformed Theological Seminary, Taipei, Taiwan

\section{Australia}

Allan M. Harman, Presbyterian Theological College, Victoria, Australia Peter Hastie, Presbyterian Theological College, Victoria, Australia Mark D. Thompson, Moore Theological College, Newtown, Australia

\section{Europe}

Henri Blocher, Faculté Libre de Théologie Évangélique, Vaux-sur-Seine, France Leonardo De Chirico, Istituto di Formazione Evangelica e Documentazione,

Padova, Italy

David Estrada, University of Barcelona, Barcelona, Spain Ian Hamilton, Cambridge Presbyterian Church, Cambridge, UK Roel Kuiper, Kampen Theological University, Kampen, Netherlands José de Segovia, Iglesia Reformada de Madrid, Madrid, Spain Herman J. Selderhuis, Apeldoorn Theological University, Apeldoorn, Netherlands Henk van den Belt, University of Groningen, Groningen, Netherlands Paul Wells, Faculté Jean Calvin, Aix-en-Provence, France

\section{North America}

Greg Beale, Westminster Theological Seminary, Philadelphia, USA

Joel R. Beeke, Puritan Reformed Theological Seminary, Grand Rapids, USA

Gerald L. Bray, Samford University, Birmingham, USA

William Edgar, Westminster Theological Seminary, Philadelphia, USA

Richard B. Gaffin Jr., Westminster Theological Seminary, Philadelphia, USA

Peter A. Lillback, Westminster Theological Seminary, Philadelphia, USA

David (Eung-Yul) Ryoo, Centreville, USA, formerly of Chongshin Seminary, Seoul, Korea

Carl R. Trueman, Westminster Theological Seminary, Philadelphia, USA Jason Van Vliet, Canadian Reformed Theological Seminary, Hamilton, Canada Jason Hing Kau Yeung, Ambrose University, Calgary, Canada Jason Zuidema, Concordia University, Montréal, Canada

\section{South America}

Davi Gomes, Mackenzie Presbyterian University, São Paulo, Brazil Mauro Meister, Andrew Jumper Graduate Center, São Paulo, Brazil 
